\title{
O lúdico na sala de aula
}

\author{
de Língua Portuguesa
}

no Fundamental II

Dissertação apresentada à Faculdade de Educação da Universidade de São Paulo, como requisito parcial para obtenção de título de mestre.

Área de Concentração: Linguagem e Educação

Orientadora: $\operatorname{Prof}^{\mathrm{a}}$. Dr ${ }^{\mathrm{a}}$. Idméa Semeghini-Siqueira

São Paulo

2008 
Autorizo a reprodução e divulgação total ou parcial deste trabalho, por qualquer meio convencional ou eletrônico, para fins de estudo e pesquisa, desde que citada a fonte.

Catalogação na Publicação

Serviço de Biblioteca e Documentação

Faculdade de Educação da Universidade de São Paulo

375.136 .9

C837L
Costa, Andréa Volante

O lúdico na sala de aula de língua portuguesa no fundamental II / Andréa Volante Costa ; orientação Idméa Semeghini-Siqueira. São Paulo : s.n., 2008.

229 p. : il.

Dissertação (Mestrado - Programa de Pós-Graduação em Educação.Área de Concentração : Linguagem e Educação) - Faculdade de Educação da Universidade de São Paulo.

1. Língua portuguesa - Estudo e ensino 2. Jogo - Educação 3. Ensino fundamental 4. Língua inglesa - Metodologia 5. Ensino e aprendizagem I. Semeghini-Siqueira, Idméa, orient. 
Andréa Volante Costa

O lúdico na sala de aula de Língua Portuguesa no Fundamental II

Dissertação apresentada à Faculdade de Educação da Universidade de São Paulo, como requisito parcial para obtenção de título de mestre.

Área de Concentração: Linguagem e Educação

Aprovado em:

Banca Examinadora:

Prof. Dr.

Instituição:

Assinatura:

Prof. Dr.

Instituição:

Assinatura:

Prof. Dr.

Instituição: Assinatura: 
Alo meu pai e à minha mãe

Que o amor que thes tenho seja sempre a luz que me guie

Qsó Deus sabe o quanto gostaria que estivessem ambos aqui hoje

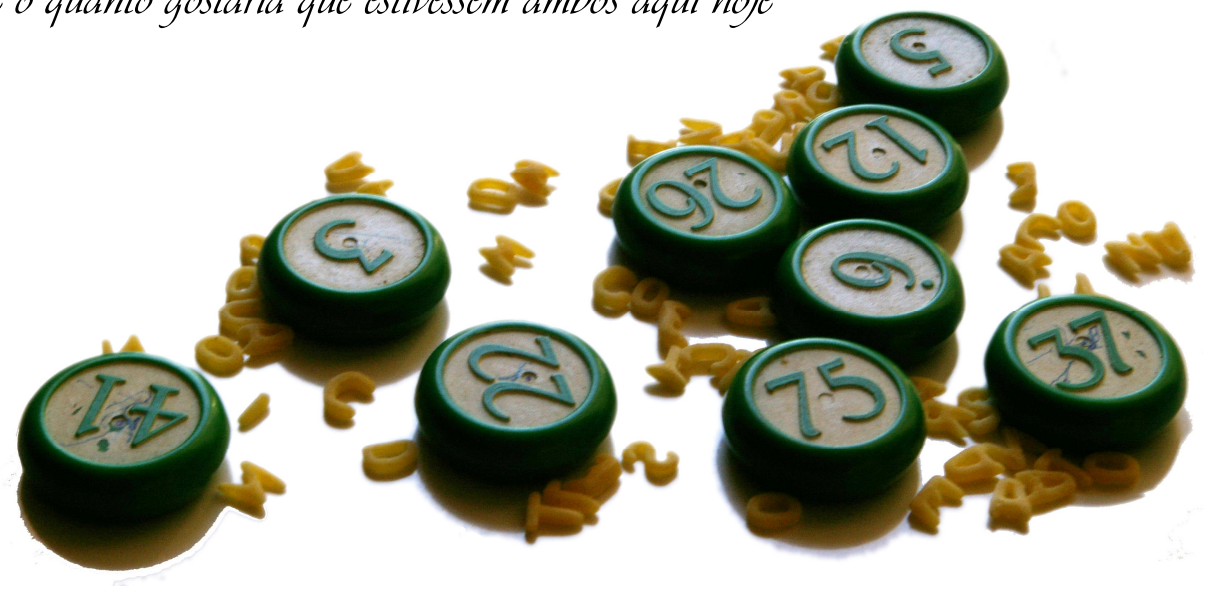




\section{AGRADECIMENTOS}

A Deus, por tudo.

À minha orientadora, Profa. Dra. Idméa Semeghini-Siqueira, por ter me mostrado o caminho.

Ao meu marido, Gilberto de Lima Araújo, por ter caminhado comigo.

A todos os professores e alunos que tornaram essa caminhada possível, em especial, às Professoras Doutoras Tizuko Morchida Yamazaki e Maria Lúcia Victorio de Oliveira Andrade, pelas valiosas observações feitas no momento da qualificação; às professoras e aos alunos que gentilmente concordaram em ser sujeitos desta pesquisa; ao Professor Doutor Nílson José Machado, pela acolhida no momento mais difícil dessa caminhada.

Agradeço ainda à Lílian Cirne Gentil, coordenadora da escola pública onde realizei o minicurso de oralidade, leitura e escrita, pelo apoio e confiança.

A todos aqueles que me acompanharam nas horas de reflexão. 
COSTA, A. V. O lúdico na sala de aula de Língua Portuguesa no Fundamental II. 2008.

271 f. Dissertação (Mestrado em Educação) - FEUSP, USP, São Paulo, 2008.

\section{RESUMO}

Este trabalho tem por objetivo a reflexão sobre uma alternativa de ensino e aprendizagem de Língua Portuguesa no Fundamental II cujo foco esteja no desenvolvimento efetivo das habilidades de leitura, oralidade e escrita por meio de atividades lúdicas. Para tanto, pautou-se pela experiência bem sucedida com esse tipo de recurso no ensino e aprendizagem de Língua Inglesa, notadamente em cursos de idiomas, cuja orientação metodológica é a Abordagem Comunicativa, e, em especial, o Task-based Language Teaching. O conceito de jogo aqui empregado provém das obras de Huizinga (2004), Wittgenstein (1975) e Brougère (1995, 1999), enquanto a relação entre jogo e Educação foi discutida tendo em vista as considerações de Kishimoto $(1992,1994,1998,2001,2007)$, Brougère $(1995,1999)$ e Macedo, Petty e Passos (2005), e entre jogo e língua estrangeira, por Crookall e Oxford (1990) e Bullards (1990). Discutiu-se as abordagens e metodologias mais difundidas no Brasil (FERRO, 1998; RODRIGUES, 2005; BERGO E GOMES, 1985) com a finalidade de se contextualizar a utilização do jogo no Task-based Language Teaching (ELLIS, 2003). A análise do que se compreende como tarefa central do ensino e aprendizagem de Língua Portuguesa privilegiou quatro pontos de vista distintos: o da tradição escolar, dos resultados das avaliações do ensino Fundamental, da perspectiva oficial $(\mathrm{PCN})$ e dos estudos lingüísticos voltados à Educação. Partindo desse referencial teórico, realizou-se em duas etapas uma pesquisa de cunho etnográfico. A Primeira Entrada em Campo consistiu na observação de aulas de Língua Portuguesa e de Língua Inglesa extracurricular em um colégio particular em São Paulo. Objetivou-se verificar como tem sido a prática efetiva nessas disciplinas com relação ao uso de jogos em sala de aula, concluindo-se que $60 \%$ do tempo das aulas observadas de Língua Inglesa foram ocupados por atividades lúdicas, enquanto, a rigor, nenhuma atividade desse caráter ocorreu na de Língua Portuguesa. Na Segunda Entrada em Campo realizou-se um minicurso de leitura, oralidade e escrita, ministrado pela pesquisadora a alunos da rede pública de ensino, no qual verificou-se as possibilidades reais de sucesso de uma metodologia de Língua Portuguesa cuja prática considerasse as atividades lúdicas como uma alternativa ao excesso de atividades metalingüísticas revelados por estudos de Neves (2003) e SemeghiniSiqueira $(1998,2006 a)$. O referencial metodológico para a elaboração das aulas do minicurso pautou-se pelos conceitos de Avaliação Diagnóstica e Formativa (SEMEGHINI-SIQUEIRA, 1997, 2002) e Seqüência Didática (SCHNEUWLY; DOLZ; NOVERRAZ, 2007) como forma de estruturação para atividades lingüísticas e epilingüísticas (SEMGHINI-SIQUEIRA, 1977, 1997, 2001, 2005, 2006b, 2006c; FRANCHI, 1991; GERALDI, 1985, 1991, 2002; TRAVAGLIA, 1996; POSSENTI, 1996), organizadas em torno do gênero textual entrevista. A inserção de atividades lúdicas que privilegiaram diversas habilidades e diferentes formas de abordagem da língua resultou em um aprendizado mais significativo e eficiente do que aquele observado em aulas de Língua Portuguesa cujas atividades restringem-se apenas às metalingüísticas.

Palavras-chave: Lúdico, Task-based language teaching, Seqüência Didática, Língua Portuguesa. 
COSTA, A. V. O lúdico na sala de aula de Língua Portuguesa no Fundamental II.2008.

271 f. Dissertação (Mestrado em Educação) - FEUSP, USP, São Paulo, 2008.

\begin{abstract}
This dissertation aims at reflecting upon an alternative to Portuguese learning and teaching in Middle school ${ }^{1}$ in which the focus is the development of the proficiency in reading, writing and speaking by means of game-like activities. Therefore, it bears resemblance to the highly successful experience conducted by English courses in line with the Communicative Approach, specially, those of Task-based Language Teaching orientation. The concept of game hereafter presented comes from the works of Huizinga (2004), Wittgenstein (1975) and Brougère (1995, 1999), meanwhile the relationship between games and education relies upon the considerations of Kishimoto $(1992,1994,1998,2001,2007)$, Brougère $(1995,1999)$ and Macedo, Petty e Passos (2005); as for games and second language learning and teaching, by Crookall and Oxford (1990) and Bullards (1990). Approaches and methodologies with a greater importance in the Brazilian context (FERRO, 1998; RODRIGUES, 2005; BERGO E GOMES, 1985) were discussed in order to provide background information on the usage of games in Task-based Language Teaching (ELLIS, 2003). Four points of view were privileged to the analysis of the main reasons for learning and teaching Portuguese: the schooling tradition, the results of the evaluation conducted to measure the performance of the students enrolled on the Middle school, the official perspective (PCN) and the linguistic studies related to Education. Having this theoretical scope in mind, two different pieces of ethnographic research were conducted. The first one consisted of the observation of both Portuguese and English (extracurricular) classes at a private school in São Paulo, so that it would be possible to verify whether their delivery has really been taking into consideration the use of games or not. It was reached the conclusion that $60 \%$ of the time spent in the English classes observed were on game activities. On the other hand, none activity was observed during the Portuguese class. In the SECOND FIELD STUDY, there was a mini-course of reading, writing and speaking, taught by the researcher, in which students from a public school in São Paulo participated in. Its main objective was to access the real possibilities of success in teaching Portuguese by making use of game activities instead of the metalinguistic ones, pointed as the major resource for Portuguese classes by Neves (2003) and Semeghini-Siqueira (1998, 2006a). The methodological reference for the mini-course is based upon the concepts of "Avaliação Diagnóstica e Formativa" (SEMEGHINI-SIQUEIRA, 1997, 2002) and "Seqüência Didática" (SCHNEUWLY; DOLZ; NOVERRAZ, 2007) as a means of structuring the linguistic and epilinguistic activities (SEMGHINI-SIQUEIRA, 1977, 1997, 2001, 2005, 2006b, 2006c; FRANCHI, 1991; GERALDI, 1985, 1991, 2002; TRAVAGLIA, 1996; POSSENTI, 1996) around the interview genre. As a result, the game activities carried out in the Portuguese classes held by the mini-course proved to be very effective, therefore the learning was enriched by the variety of approaches as well as the range of skills involved in performing the tasks.
\end{abstract}

Keywords: Game, gaming, Task-based language teaching, Portuguese.

\footnotetext{
${ }^{1}$ Nome dado às séries cujos alunos têm entre 11 e 14 anos nos Estados Unidos. Na Inglaterra, a co-relação é feita com as Secundary schools (alunos de 11 a 15 anos).
} 


\section{LISTA DE FIGURAS}

Figura 1 Procedimento para organização das situações didáticas, segundo os PCN de Língua Portuguesa dos terceiro e quarto ciclos $(1998$, p. 35) .....

Figura 2 - Esquema da seqüência didática (SCHNEUWLY; DOLZ; NOVERRAZ, 2007, p. 98)

Figura 3 - Distribuição de tipos de atividades por etapas da Unidade de Trabalho

Figura 4 - Relação entre tempo ocupado por atividades lúdicas e as demais atividades, em relação a cada etapa da aula.

Figura 5 - Relação entre tempo e tipo de atividade realizada na aula de Português.

Figura 6 - Relação entre problemas mais freqüentes e unidades lingüísticas apontada pela ADeF.

Figura 7 - Exemplo de atividade realizada pelos alunos no "Wall game".

Figura 8 - Atividade epilingüística de acentuação. 197

Figura 9 - Exemplo de uma produção diagramada.

Figura 10 - Relação entre os problemas mais freqüentes e as unidades lingüísticas na produção inicial

Figura 11 - Relação entre os problemas mais freqüentes e as unidades lingüísticas na produção final

Figura 12 - Comparação das ocorrências problemáticas entre a produção inicial e a produção

final

Figura 13 - Comparação das ocorrências problemáticas nas produções finais com maior e menor incidência de problemas ......................................................................... 206

Figura 14 - Carta de um dos alunos participantes do minicurso de oralidade, leitura e escrita à professora-pesquisadora. 


\section{LISTA DE FOTOS}

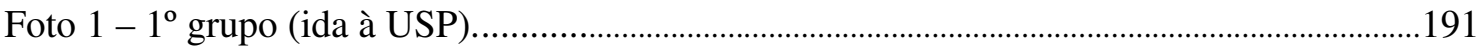

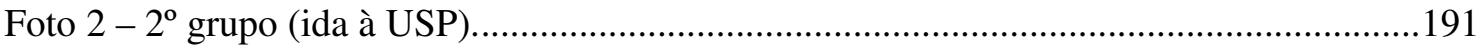

Foto 3 - Alunos que participaram da festinha de encerramento do curso, a coordenadora do Ensino Fundamental e a professora-pesquisadora...............................................................201 


\section{LISTA DE QUADROS}

Quadro 1 - Questões orientadoras da ENTRADA EM CAMPO.

Quadro 2 - Objetivos do ensino e aprendizagem de Língua Portuguesa no $3^{\circ}$. e $4^{\circ}$. Ciclos, segundo os PCN de Língua Portuguesa dos terceiro e quarto ciclos (1998, p. 49 - 52) ....... 110

Quadro 3 - Entendimentos sobre o que é gramática, segundo Travaglia (1996, p. 30-33) ... 118

Quadro 4 - Aprender e ensinar Gramática 1-2-3 na escola: qual? quanto? como? para quê? 118

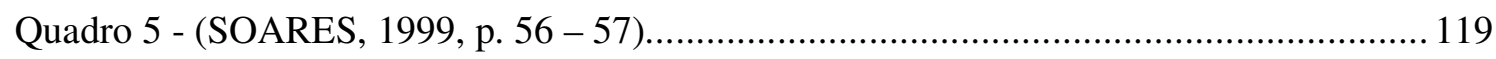

Quadro 6 - Programa das atividades realizadas no minicurso de oralidade, leitura e escrita 157

Quadro 7 - Principais tópicos da "Grade para [...] Avaliação Diagnóstica e Formativa [...]"

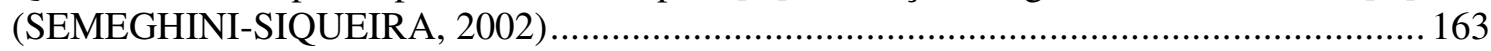

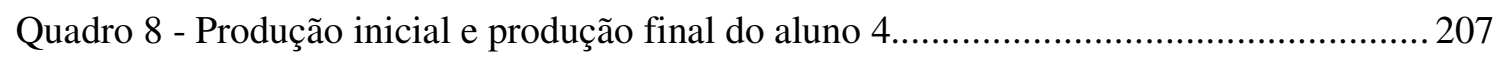




\section{LISTA DE TABELAS}

Tabela 1 - Relação de alunos por sala no colégio onde ocorreu a pesquisa de campo............ 50

Tabela 2 - Relação de alunos por série da Segunda Entrada em Campo ............................... 53

Tabela 3 - Seqüência do TBLT, segundo Willis (ELLIS, 2003, p. 244) …......................... 91

Tabela 4 - Seqüência do TBLT, segundo Nunan $(2004$, p. 20)......................................... 93

Tabela 5 - Incorreções ortográficas concernentes à produção coletiva....................................194 


\section{SUMÁRIO}

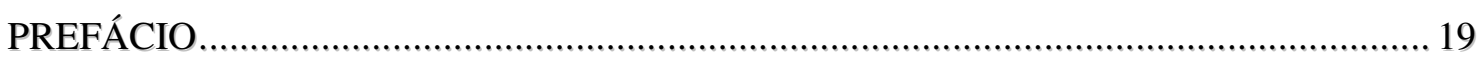

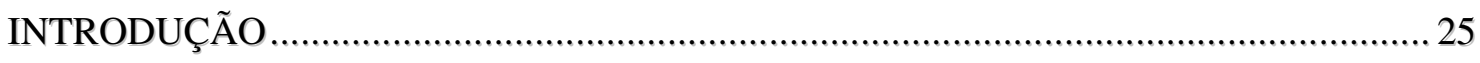

1. METODOLOGIA E SUJEITOS DA PESQUISA ........................................................... 33

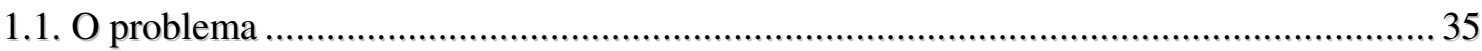

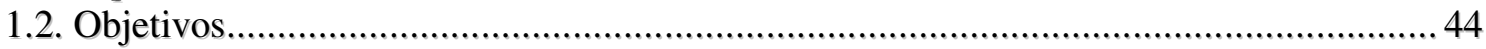

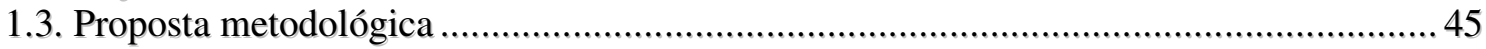

1.4. Primeira Entrada em Campo: pesquisa de cunho etnográfico investigativo ................... 48

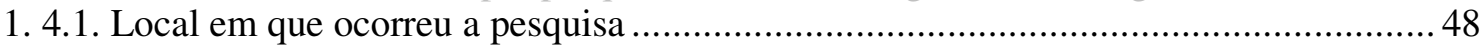

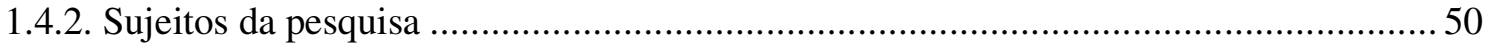

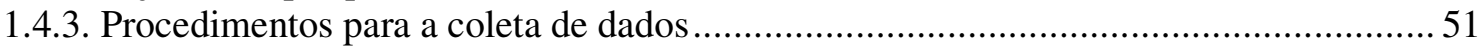

1.5. Segunda Entrada em Campo: Investigação ação ......................................................... 51

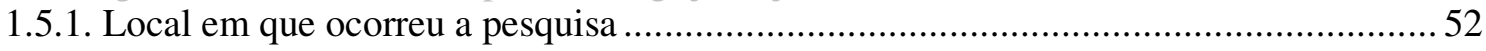

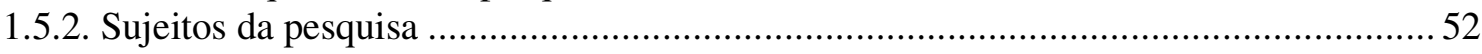

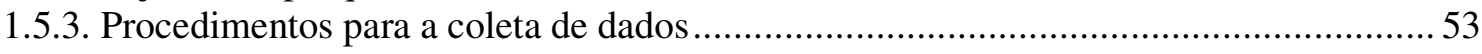

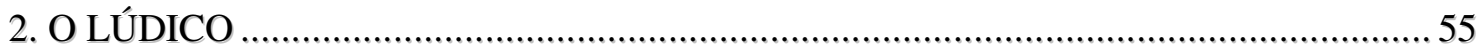

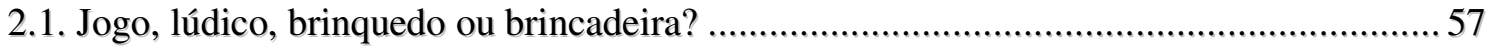

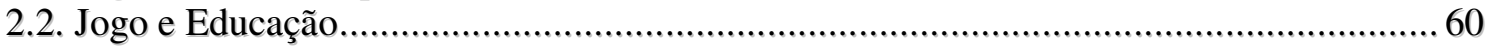

2.3. O lúdico e o ensino e aprendizagem de Língua Estrangeira ........................................66

3. ENSINO DE LÍNGUA INGLESA COMO LÍNGUA ESTRANGEIRA: UM MODELO PARA O USO DO LÚDICO EM SALA DE AULA …................................................ 75

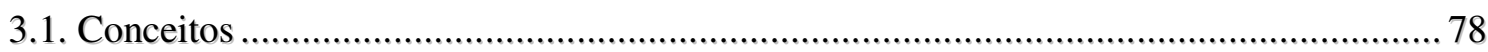

3.2. Abordagens e Metodologias mais difundidas no Brasil.................................................. 79

3.3. Da Abordagem Comunicativa ao Task-based language teaching ............................... 89

4. ENSINO DE LÍNGUA PORTUGUESA: PERSPECTIVAS E POSSIBILIDADES .........95

4.1. Gramática e aula de Português: são a mesma coisa? .................................................... 98

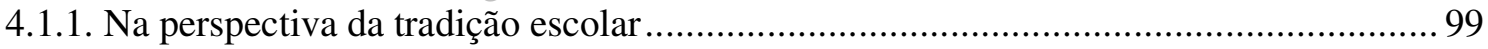

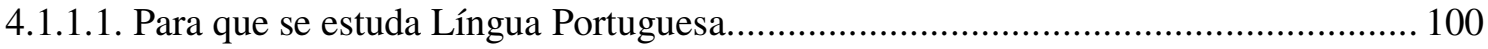

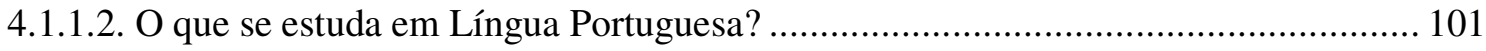

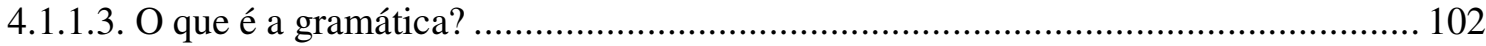

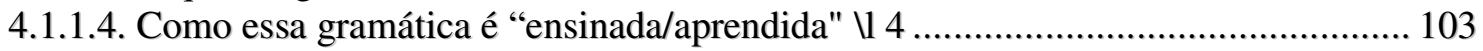

4.1.1.5. Qual o papel do ensino de Língua Portuguesa? ...................................................... 104

4.1.2. O que revelam as avaliações oficiais sobre o ensino Fundamental?......................... 105

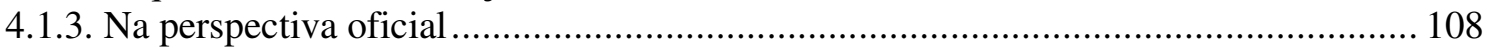

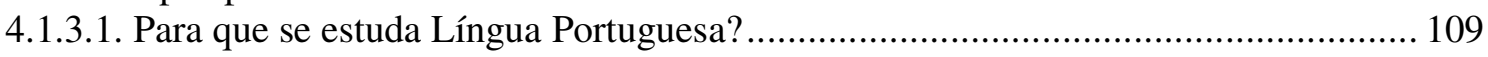

4.1.3.2. O que se estuda em língua Portuguesa?........................................................ 111

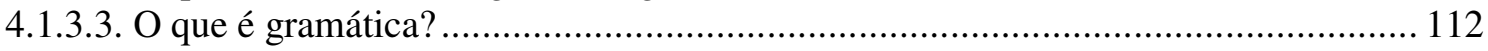

4.1.3.4. Qual o papel do ensino de Língua Portuguesa? .................................................. 113

4.1.4. Na perspectiva dos estudos lingüísticos ligados à Educação...................................... 113 


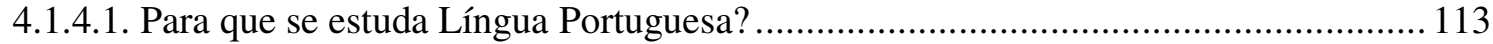

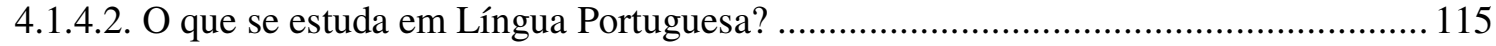

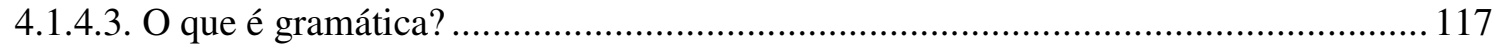

4.1.4.4. Qual o papel do ensino de Língua Portuguesa? ................................................. 119

4.2. Crítica ao ensino e aprendizagem de gramática no Fundamental II ............................. 120

4.3. Alternativa para o ensino e aprendizagem de Língua Portuguesa - Avaliação Diagnóstica

e Formativa, Sequiência Didática e Atividades Lingüísticas e Epilingüísticas...................... 122

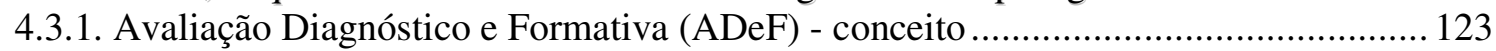

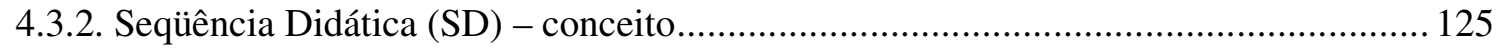

4.3.3. Atividades lingüísticas (ALs), epilingüísticas (AEs) e metalingüísticas (AMs)-

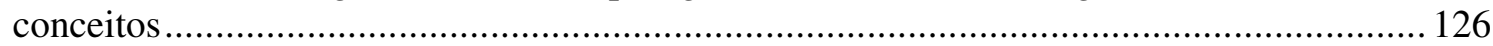

5. ENTRADA EM CAMPO: IN LOCO , COMO TUDO ISSO ACONTECE DE FATO?. 131

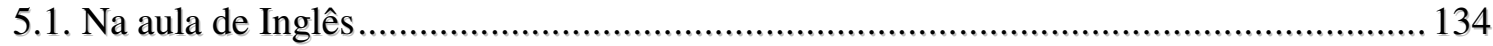

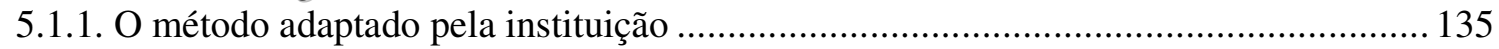

5.1.2. Do método à prática concreta: observações das aulas de Inglês ................................ 137

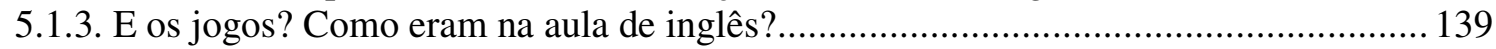

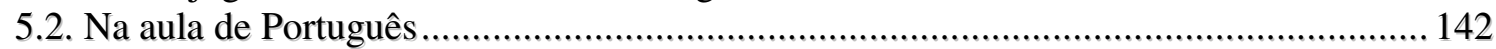

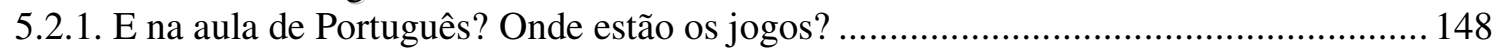

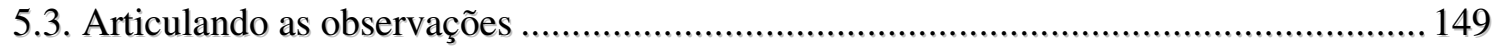

6. UMA PROPOSTA PARA A UTILIZAÇÃO DO LÚDICO NO ENSINO E APRENDIZAGEM DE LÍNGUA PORTUGUESA NO FUNDAMENTAL II: TRABALHANDO COM ATIVIDADES EPILINGÜÍSTICAS ….................................... 153

6.1. A proposta: Minicurso de oralidade, leitura e escrita............................................... 156

6.2. Caminhos apontados pela Avaliação Diagnóstica e Formativa..................................... 161

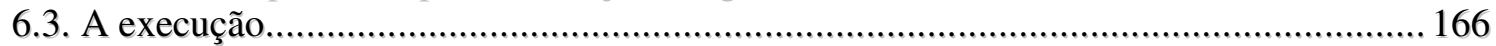

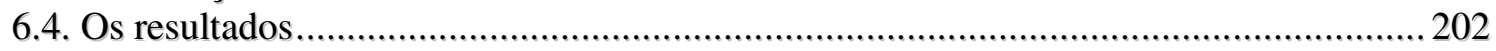

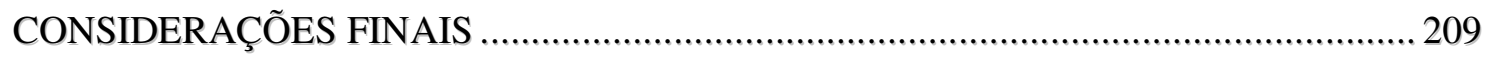

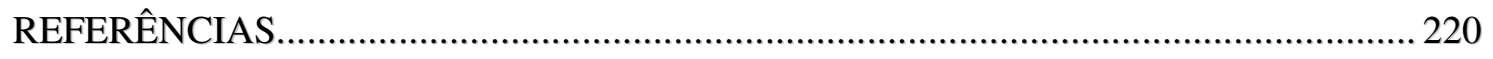

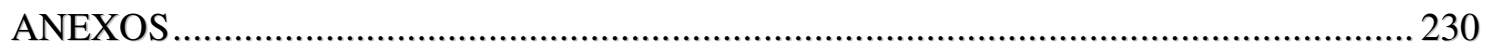




\section{PREFÁCIO}

\section{A vontade}

Se você quiser construir um navio, não convoque homens para juntar madeira, dar ordens e dividir o trabalho. Antes, ensine-os a se apaixonar e desejar o eterno e imenso mar.

Antoine Saint-Exupéry

Em inglês, a dicotomia entre "ser" e "estar" não existe: tudo é verb to be. No nosso português, porém, não é assim, não! Ser professora de Português, mas estar professora de Inglês não é um estado - é uma condicional. Mas foi dessa encruzilhada de caminhos, do que decidi percorrer na minha vida acadêmica e do outro, o profissional, que nasceu a dúvida que norteia este trabalho: será que não há uma forma, como no inglês, de fazer com que aquilo que sou e aquilo que estou não possam se fundir no plano do conhecimento e as experiências de uma e outra área comunicarem-se de maneira a contribuir positivamente para a minha prática de ensino?

Embora a questão pareça simples, já que, salvo as devidas diferenças intrínsecas, o ensino de língua materna e o de língua estrangeira são, ambos, ensino de idiomas, percebi, na prática, que não é tão simples assim. Depois de alguns anos trabalhando como professora de Inglês em vários institutos de idiomas, em 2004, decidi arriscar-me a ser professora "de verdade": fui lecionar Português em um colégio particular e, seis meses depois, em um outro, da prefeitura, ambos no município de São Paulo.

Ironia à parte, a verdade é que nesses estabelecimentos de ensino, os chamados cursos livres, o professor é registrado (quando o é...) como técnico de idiomas, e não professor. Também não há preocupação alguma em ser educador, nem em ter cursado licenciatura de qualquer espécie. Acreditei, pois, que, indo a uma instituição de ensino regular estaria, enfim, exercendo minha profissão.

Se encontrei, por um lado, o reconhecimento formal nesse novo momento de minha carreira, por outro, perdi de vista aquilo que entendia como minha função efetiva em sala de aula. 
Atrelados à gramática normativa estavam os intermináveis exercícios de análise morfológica, sintática e aquela visão de que o ensino e a aprendizagem da língua deveriam necessariamente passar pelo seu domínio metalingüístico. Menos proponente de desafios e mais provedora de respostas, tornei-me agente de uma prática com a qual não concordava.

Foi, porém, a produção dos textos escritos por meus alunos que me levou, de forma mais consciente, a verificar que, de fato, algo não ia bem na minha aula de Português. Após 2 anos de ensino de língua estrangeira, de modo geral, meus alunos eram capazes de se comunicarem e escreverem com relativa facilidade em inglês, enquanto os de Língua Portuguesa, da $7^{a}$ série do Ensino Fundamental, embora se expressassem muito bem oralmente, produziam textos escritos extremamente precários. O que havia na minha aula de Inglês que se perdeu na de Português?

\section{O jogo}

E o jogo da vida se joga nas circunstâncias vitais que nos constituem, que nos foram legadas como se fossem as cartas para jogar o nosso jogo. E mesmo na perspectiva estritamente existencialista o que importa não são as cartas que recebemos, mas o modo como jogamos com elas, ou o que fazemos com o que a vida fez de nós.

Nílson José Machado (MACHADO, 2006, p. 78)

"22. Dois patinhos na lagoa!"

Foi nas rimas do bingo, com meu pai, que aprendi os números, e nas sopas de letrinhas que conheci o alfabeto, com minha mãe. Provavelmente por isso, quando foi a minha vez de ensinar, foi ao jogo que recorri.

Assim, minhas primeiras experiências como professora também foram as primeiras com jogos adaptados ao ensino de idiomas. Quer tenha sido porque tanto a metodologia do curso onde trabalhava, quanto o livro didático adotado, ou ainda, por causa do incentivo que a coordenadora dava aos professores que adaptavam as atividades do livro de maneira a tornálas mais "customizadas" (como lá diziam), o uso de jogos em sala de aula pareceu-me algo bastante difundido e até, porque não, normal, no ensino de idiomas. 
Entusiasmada com os resultados positivos obtidos pelos alunos e movida pela minha curiosidade, fui à busca de obras específicas que trouxessem sugestões novas de atividades lúdicas que pudessem ser incorporadas à minha aula. Não que tais sugestões não surgissem durante as próprias aulas, já que, muitas vezes, especialmente quando meus alunos eram crianças, eles próprios sugeriam algumas formas de jogar muito melhores do que aquelas que eu havia proposto.

Ainda assim, e, talvez por isso mesmo, pela comprovação reiterada de que novos jogos seriam bem-vindos, fui à busca desses livros com mais idéias. Descobri que há uma profusão deles, principalmente importados, e alguns também editados no Brasil por editoras especializadas. Todos, porém, dedicados ao ensino de língua estrangeira. Seu conteúdo principal, ora catalogado por tópico gramatical, ora pelas funções que desempenham na comunicação, ou ainda, por nome, é os "jogos didáticos", que variam de sugestões simples como rimas para o ensino de cores até atividades que requeiram um considerável nível de elaboração, como o "Desafio de Einstein".

Quando, porém, finalmente fui trabalhar como professora de Português, minha primeira atitude foi a de transpor, ainda que sem muito "conhecimento de causa", as experiências que havia desenvolvido no ensino de língua estrangeira ao de língua materna.

Três foram os meus choques: o primeiro, com os próprios alunos, pois ao mesmo tempo em que se viam compelidos a participar, não encaravam jogos como atividades produtivas acreditavam estarem "apenas" brincando; o segundo, com o fato de não haver quase subsídio algum sobre jogos desenvolvidos para o ensino de Português, fosse no livro didático, ou em outros livros - todas as referências que encontrei tratavam sobre os seu uso com crianças pequenas, e eu era professora do Fundamental II; e, por fim, com a coordenação do colégio, que se dizia sócio-construtivista, mas assumia "que a proposta poderia ser boa, mas os pais dos alunos não a aceitariam".

Percebi, então, que tais atividades lúdicas ainda não haviam sido acolhidas no ensino e aprendizagem de Língua Portuguesa. Por que, se seus resultados eram tão expressivos (e comprovados) no de Língua Inglesa? 


\section{O projeto}

Se é certo que todo projeto nasce de uma ilusão, também o é o fato de que é preciso ir além dela.

Nílson José Machado (MACHADO, 2006, p. 66)

Paralelamente às experiências profissionais já relatadas, tive a oportunidade de entrar em contato, por meio da disciplina de MELP (Metodologia do Ensino de Língua Portuguesa), ministradas no programa de licenciatura da Faculdade de Educação da Universidade de São Paulo pela Profa. Dra. Idméa Semeghini-Siqueira, com uma visão de ensino e aprendizagem de Língua Portuguesa muito diferente da qual eu estava submetida (e subjugada).

Nessa perspectiva, que era nova para mim, ensinar Português não se confinava apenas à gramática - que aprendi estar compreendida em três tipos de abordagens: a lingüística, a epilingüística e a metalingüística. E foram nas atividades epilingüísticas que divisei uma aresta em comum - que eu tanto queria encontrar, uma possibilidade de prática de ensino de Língua Portuguesa que contemplasse o que eu havia vivenciado na de Língua Inglesa, com os jogos. Porém, naquela disciplina ainda, para além da experiência com atividades de caráter lúdico, entrei em contato com os conceitos de Avaliação Diagnóstica e Formativa (SEMEGHINI-SIQUEIRA, 1997) e de Seqüência Didática (SCHNEUWLY, DOLZ, 2007; SEMEGHINI-SIQUEIRA, 2001), também novidades para mim.

Por meio desse novo referencial teórico, comecei a imaginar como seria dar aulas de Português em que eu pudesse partir daquilo que o aluno sabia - e não do que eu inferia, ou queria, que soubesse - para construir atividades que possuíssem um objetivo real: melhorar a compreensão de leitura e escrita de meus alunos.

$\mathrm{Na}$ busca de mais conhecimento sobre o assunto, iniciei o meu mestrado. A princípio, meu foco estava nas investigações sobre a relação entre o livro didático e a presença de atividades epilingüísticas na aula de Língua Portuguesa. Aos poucos, minha paixão por jogos e a necessidade de entender como eles poderiam ser úteis ao ensino e aprendizagem de Língua Portuguesa foram emergindo, e, quase subliminarmente, orientando minhas escolhas. 
O trabalho que por hora apresento é, por assim dizer, o resultado desse percurso tortuoso, desse meu desassossego. Não tenho a pretensão de dizer o que o poeta que, melhor do que eu, conheceu essa palavra, disse:

Creio que dizer uma coisa é conservar-lhe a virtude e tirar-lhe o terror. Os campos são mais verdes no dizer-se do que no seu verdor. As flores, se forem descritas com frases que as definam no ar da imaginação, terão cores de uma permanência que a vida celular não permite $[. . .]^{2}$

Mas ainda assim, não me furto ao registro da minha pequena contribuição.

${ }^{2}$ PESSOA, F. Livro do desassossego. Companhia das Letras: São Paulo. 2006. p. 59. 
INTRODUÇÃO

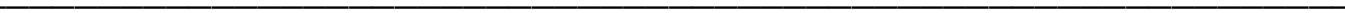




\section{INTRODUÇÃO}

Este trabalho visa empreender reflexões acerca do uso de atividades lúdicas no ensino e aprendizagem de Língua Portuguesa pautado pela experiência já consagrada desse tipo de atividade no ensino de Língua Inglesa, notadamente em cursos extracurriculares de idiomas.

Tendo em vista os resultados insuficientes obtidos nos últimos anos pelos alunos da rede escolar paulista nos exames de avaliação da qualidade do ensino promovidos pelos órgãos oficiais, notadamente o $\mathrm{SAEB}^{3}$, a Prova Brasil e o SARESP ${ }^{4}$, uma das questões mais recorrentes entre os educadores do Ensino Fundamental é como ensinar os alunos a ler e a escrever de forma eficaz.

Para isso, faz-se necessário saber, antes, no que consiste a prática de sala de aula, sobretudo, a de Língua Portuguesa, de forma que seja possível pensar-se em mudanças/ adequações/ sugestões plausíveis. Segundo dados coletados por Neves (2003), mais de $90 \%$ do tempo total do programa dessa disciplina é gasto com gramática, preferencialmente na execução de exercícios de reconhecimento e classificação de palavras e estruturas (75,56\%). Segundo Franchi (1991, p. 20)

Interessa pouco descobrir a melhor definição de substantivo ou de sujeito ou do que quer que seja. No plano em que se dá a análise escolar, certamente não existem as boas definições. [...] Mas interessa, e muito, levar os alunos a operar sobre a linguagem, rever e transformar seus textos, perceber nesse trabalho a riqueza das formas lingüísticas disponíveis para suas mais diversas opções. [grifos do autor]

Concordam com esse autor Travaglia (1996), Possenti (1996), Geraldi (2002) e SemeghiniSiqueira (1997, 1998, 2005, 2006a, 2006c), que também defendem a priorização de atividades que levem o aluno ao uso e não à análise da língua.

Desta forma, procurou-se aqui propor uma alternativa tanto ao modelo tradicional de ensino e aprendizagem de Língua Portuguesa, referido como ineficaz, mas frequiente, pelos autores

\footnotetext{
${ }^{3}$ Sistema de Avaliação do Ensino Brasileiro.

${ }^{4}$ Sistema de Avaliação do rendimentos Escolar do Estado de São Paulo.
} 
supra citados, quanto a alguns dos problemas mais comumente apontados por educadores, como a indisciplina e a falta de participação.

Para tanto, as reflexões de Jovanovic (1992, p. 179) sobre "[...] a análise conjugada das relações entre língua materna e língua estrangeira" orientaram a escolha pela aproximação da metodologia de ensino adotada pela maioria dos cursos livres de inglês em funcionamento em São Paulo, a Abordagem Comunicativa, à prática de ensino de Língua Portuguesa. Segundo o autor (JOVANOVIC, 1992, p. 178):

Na prática escolar, portanto, o aluno acaba sendo alvo de uma abordagem centrada na AGT (Abordagem da Gramática-e-Tradução), quando se trata de ensino de língua materna, [...] Contraditoriamente ou não, o mesmo estudante pode acabar sendo alvo de abordagens como a AAL (Abordagem Audiolingual) ou a AC (Abordagem Comunicativa), quando se trata de ensino de língua estrangeira, ou, na maioria das vezes, da própria AGT, sem que se evidencie o fato - mais do que óbvio - de que todos os códigos lingüísticos são instrumentos de comunicação e, como tais, devem se encarados de modo idêntico tanto por aqueles que ensinam, quanto por aqueles que aprendem (ou deveriam aprender). [grifo nosso].

Ponderadas as diferenças entre o ensino de língua estrangeira e o de língua materna, Jovanovic (1992) aponta para a importância de ambos serem tratados como ensino de idiomas e, portanto, para o contra-senso do pouco aproveitamento das estratégias desenvolvidas e empregadas em cada uma dessas disciplinas em favor da outra.

Vale ressaltar o que Possenti (1996, p. 16) considerou como decisão fundamental quanto a experiências no ensino de língua materna:

[...] uma decisão [...] importante, no domínio do ensino de língua materna, é que não se façam experiências. [...] É que, se o experimento fracassa, não se desperdiçam amostras de matérias, mas pedaços de vidas, partes de projetos dos alunos, às vezes, vidas e projetos inteiros.

Outra questão que pautou a escolha pelo intercâmbio entre os conhecimentos metodológicos do ensino de língua estrangeira e os de língua materna foram os resultados positivos obtidos pela Abordagem Comunicativa. Trata-se não apenas de um modelo de sucesso, afastando riscos de um experimentalismo infundado, mas também da possibilidade do emprego de (1) estratégias que priorizam atividades primordialmente lingüísticas e epilingüísticas, e (2) uma 
orientação metodológica cujo entendimento do processo de ensino e aprendizagem de uma língua vai muito além da formação de um hábito ou da mera comunicação de frases e palavras avulsas (RICHARDS; RODGERS, 2001, p. 161).

O trabalho com a transposição de uma metodologia de ensino de língua estrangeira não teria sentido, porém, se não fosse feito um recorte daquilo que realmente pode ser aproveitado ao de língua materna. Optou-se pela forma como as atividades lúdicas são empregadas na rotina de sala de aula de Língua Inglesa como modelo para o seu uso em Língua Portuguesa.

A escolha se deu graças à (1) possibilidade de adaptação simples das atividades originais ao ensino e aprendizagem do Português; (2) abundância de bibliografia de consulta, com uma miríade de sugestões; (3) facilidade em se tornarem veículos para atividades lingüísticas e epilingüísticas, além de (4) serem um forte motivador para os alunos (e, porque não, para os professores também).

Ao re-contextualizarem a aprendizagem, os jogos criam um ambiente livre das interferências do mundo externo, proporcionando "[...] uma atmosfera de familiaridade, segurança emocional e ausência de tensão ou perigo [...] [que] oferece oportunidades para experimentar comportamentos que, em situações normais, jamais seriam tentados pelo medo do erro e punição" (KISHIMOTO , 1998, p. 140).

Por outro lado, para teóricos como Huizinga (2003) e Brougère (1995), a idéia de jogo educativo é um paradoxo (KISHIMOTO, 1992, p. 29). Isso porque, para esses autores, uma atividade só pode ser qualificada como jogo quando há a liberdade de escolha do indivíduo sobre o jogar, isto é, quem decide jogar é o próprio jogador. Em uma situação educacional, isso raramente é verdade, uma vez que quem propõe o jogo geralmente é o professor. Outro problema que esses teóricos apontam é o fato de que o jogo nunca tem uma finalidade em si mesmo, sendo o processo o seu elemento mais importante. Em um contexto didático, certamente o interesse do jogo recai no aprendizado advindo do jogar e, portanto, em um resultado.

\footnotetext{
${ }^{5}$ O excerto foi retirado de uma consideração que a autora faz sobre as idéias de Bruner (1972).
} 
Fazendo um balanço sobre o que ambos os autores dizem a respeito da questão do uso do jogo na Educação, Kishimoto (1992, p. 195) afirma que:

[...] um fator que encoraja o movimento do jogo educativo parece provir da influência crescente de teorias construtivistas, como as de Piaget (1978) e Vygotsky (1988), [...] Tais teorias foram consolidadas por um número considerável de pesquisas recentes sobre o papel do jogo no desenvolvimento social e cognitivo da criança (Christie \& Johnson, 1983; Johnson, Christie \& Wawkey, 1987 e Rubin, Rein \& Vanderberg, 1983) (apud Christie, 1991, p. 3-5).

Assim, segundo a autora (KISHIMOTO, 1992, p. 30):

Embora o problema filosófico continue sem solução, cresce o número de autores que adotam o jogo na escola em seu significado usual incorporando a função lúdica e a educativa. Entre eles, destaca-se Campagne (1989, p.113), que sugere critérios para a escolha de brinquedos de uso escolar. São eles:

1) $\mathrm{O}$ valor experimental - permitir a exploração e manipulação.

2) $\mathrm{O}$ valor da estruturação - dar suporte à construção da personalidade infantil;

3) O valor de relação - colocar a criança em contato com seus pares e adultos, com objetos e com o ambiente em geral para propiciar o estabelecimento de relações e

4) O valor lúdico - avaliar se os objetos possuem as qualidades que estimulam o aparecimento da ação lúdica.

A escolha das atividades lúdicas que fazem parte deste projeto foi feita observando-se esses valores.

A fim de contribuir com as reflexões empreendidas no meio acadêmico acerca do ensino e aprendizagem de Língua Portuguesa, propõe-se aqui a alcançar os seguintes objetivos:

(1) Realizar pesquisa bibliográfica referente ao trabalho no ensino e aprendizagem de inglês como Língua Estrangeira, segundo a Abordagem Comunicativa e, em especial no Task-based Language Teaching, com atividades lúdicas.

(2) Aplicar os conhecimentos adquiridos na observação do uso de jogos nas práticas de ensino e aprendizagem de Língua Inglesa à prática de Língua Portuguesa, 
respeitando as diferenças intrínsecas de objetivos pelos quais ambas as disciplinas se pautam.

Para tanto, dividiu-se esta monografia em 6 capítulos, seguidos das considerações finais, bibliografia, webgrafia e anexos.

O primeiro capítulo [Metodologia e sujeitos da pesquisa] apresenta uma descrição mais precisa do problema que motivou esta investigação e do objetivo que se pretende atingir. Detalha-se também a metodologia adotada, bem como a justificativa quanto à escolha dos sujeitos.

O capítulo 2 [O lúdico] é dedicado à conceituação dos termos "jogo", "lúdico", "brinquedo" e "brincadeira" sob diversos pontos de vista teóricos correntes, com a finalidade de serem estabelecidas as relações entre o lúdico e a Educação. O uso de atividades lúdicas pelo ensino de Língua Inglesa, sob a orientação da Abordagem Comunicativa, e especificamente, do Task-based Language Teaching também é tratado nesse capítulo.

No capítulo 3 [Ensino de língua inglesa como Língua Estrangeira: um modelo para o uso do lúdico em sala de aula], encontra-se uma revisão bibliográfica sobre as metodologias de ensino de Língua Inglesa de maior expressão no Brasil, seguida de um aprofundamento sobre a Abordagem Comunicativa e, em especial sobre o Task-based Language Teaching.

O capítulo 4 [Ensino de Lingual Portuguesa: perspectivas e possibilidades] discute a questão do lugar da gramática na aula de Língua Portuguesa, tanto aquele que lhe é reservado efetivamente nas práticas de ensino correntes, quanto àquele desejável por autores que defendem uma mudança em tais práticas, é central. As reflexões empreendidas sobre o assunto recorrem ao confrontamento de pontos de vistas diversos, que se pautam pela tradição escolar, pelos dados dos exames oficiais e pelo que os teóricos mais renomados do país entendem sobre a questão. Será abordada, ainda, a importância do papel das atividades lingüísticas e epilingüísticas na aula de Língua Portuguesa, assim como da realização de Avaliação Diagnóstica e Formativa e do uso de Seqüências Didáticas, para que o trabalho com textos seja voltado às necessidades verdadeiras de alunos reais - e não hipotéticos. 
O capítulo 5 [Entrada em Campo: in loco, como tudo isso acontece de fato?] trás um relato sobre a vivência de dois meses de observação de aula de duas professoras, uma de Língua Portuguesa e outra de Língua Inglesa, em aulas de um colégio particular de São Paulo. Buscam-se, por meio dessa experiência, subsídios necessários para analisar: (1) como as metodologias de ensino e aprendizagem são aplicadas de fato na prática e (2) de que modo as atividades lúdicas são inseridas no contexto de sala de aula.

No capítulo 6, [Uma proposta para a utilização do lúdico no ensino e aprendizagem de Língua Portuguesa no Fundamental II: trabalhando com atividades lingüísticas e epilinguiísticas], aventurou-se à proposição de uma forma de trabalho baseada nas conclusões extraídas tanto da teoria quanto das práticas relatadas no cap. 5. Trata-se, pois do relato de um minicurso oferecido a jovens de uma escola pública de periferia de São Paulo cujo foco das atividades recaía no uso de atividades lúdicas no ensino e aprendizagem de oralidade, leitura e escrita a alunos do Fundamental II.

Nas Considerações Finais defende-se o ganho qualitativo de um ensino e aprendizagem de Língua Portuguesa que faça uso de atividades lúdicas em lugar de excesso de exercitações metalingüísticas. 
METODOLOGIA E SUJEITOS DA PESQUISA 


\title{
1. METODOLOGIA E SUJEITOS DA PESQUISA
}

\author{
Não, não é fácil escrever. É duro como quebrar rochas. Mas voam faíscas como aços \\ espelhados. ${ }^{6}$
}

Clarice Lispector

Neste capítulo serão expostos, de forma detalhada, o problema de pesquisa e a sua relação com o objetivo deste trabalho, de maneira a ser justificada a sua pertinência.

Apresentam-se também os sujeitos que participaram da pesquisa e os procedimentos empregados para a sua realização.

\subsection{O problema}

Um problema que tem mobilizado o empenho e a reflexão da maioria dos educadores e pesquisadores da área do ensino de Língua Portuguesa é o baixo grau de letramento verificado entre os nossos alunos das séries finais do Ensino Fundamental II.

O último lugar ocupado pelo Brasil entre os demais 32 países participantes do $\mathrm{PISA}^{7}$ (Programme for International Student Assessment) ${ }^{8}$, em 2000, certamente nos dá a sensação desconfortável de que há muito trabalho ainda por ser feito.

Mesmo que um olhar para as condições de vida dos países que ocuparam os primeiros lugares da pesquisa referida revele que a má colocação do Brasil no ranking não se deve apenas a fatores intrinsecamente pedagógicos, não é possível supor-se também que o contrário seja verdade. Um exemplo claro disso é o "Índice de Desenvolvimento Humano" (IDH). Enquanto a Finlândia, um dos países mais bem qualificados em termos gerais naquele ano, obteve uma

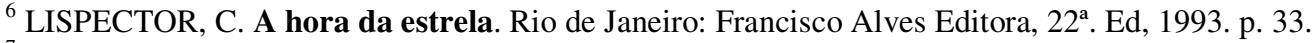

${ }^{7}$ Programa Internacional de Avaliação Comparada.

${ }^{8}$ Exame realizado por um organismo internacional, a Organização para Cooperação e Desenvolvimento Econômico, cujo propósito principal era monitorizar os resultados dos sistemas educativos por meio do desempenho de alunos de 15 anos relativo à leitura.
} 
marca de $91,7 \%$ dos requisitos necessários para o desenvolvimento integral do ser humano, o índice do Brasil foi de 74,7\%. O fato desse indicador ser composto por três características desejáveis nesse processo de desenvolvimento, a saber:

- a longevidade da população - expressa pela esperança de vida;

- seu grau de conhecimento - traduzido por duas variáveis educacionais: a taxa de alfabetização de adultos e a taxa combinada de matrícula nos três níveis de ensino; e

- sua renda ou PIB per capita, ajustada para refletir a paridade do poder de compra entre países. (PISA, 2000, p. 24)

oferece subsídios à discussão sobre a complexidade envolvida na busca por melhores resultados do nível de letramento no país. A defasagem brasileira em termos sociais, expressa pelos componentes 1 e 3 do índice, certamente tem um peso grande em relação aos países mais desenvolvidos. Porém, isso não diminui o peso do componente pedagógico, representado pelo segundo item componente. Se for levado em consideração que, cada vez mais, todos os bens culturais são mediados pela palavra escrita (basta pensar na janela para o mundo que é a Internet!), a incapacidade de tornar nossos alunos usuários competentes do sistema escrito significa furtá-los das chances de uma vida melhor e, portanto, excluí-los, não somente da escola, mas da sociedade. Portanto, soluções para os problemas no âmbito da Educação deveriam ser prioridade de qualquer governo.

Similarmente, os exames nacionais que verificam a qualidade do ensino constatam a mesma realidade que o PISA. No último SAEB (Sistema Nacional de Avaliação da Educação Básica), realizado em 2003, menos de 10\% (9,3\%) dos estudantes brasileiros que participaram da pesquisa atingiram um patamar adequado na escala de desempenho em Língua Portuguesa. Se os números em si não são animadores, o fato de terem assinalado uma curva descendente, se comparados aos do exame anterior, de $2001^{9}$, revela-se ainda mais preocupante.

Em 2005, cinco anos após a realização do primeiro PISA, o Prova Brasil não obteve resultados expressivamente diferentes daqueles observados anteriormente. Ainda que o método de avaliação tenha mudando, pois, diferentemente do SAEB, que era por amostragem, o Prova Brasil foi aplicado a todos os alunos da rede pública do país e a alguns da rede privada cujos colégios decidiram participar, mais uma vez os resultados demonstraram a fragilidade do grau de letramento em que se encontram os alunos brasileiros.

\footnotetext{
${ }^{9}$ Cuja porcentagem para o Brasil foi de 10,3\% e de São Paulo, 13,21\%.
} 
Em São Paulo, estado que interessa em particular a este trabalho, a média de acertos dos estudantes foi de 63\% (220,09 em 350). Segundo a escala de habilidades por pontos em Língua Portuguesa divulgada pelo INEP, isso significa que são capazes de "[...] compreender textos narrativos complexos, poéticos, informativos longos ou com informação científica [..]", mas não conseguem "[..] distinguir o sentido metafórico do literal de uma expressão ou localizar a informação principal em textos narrativos com traços descritivos que expressem sentimentos subjetivos e opiniões [..]" (INEP, 2007). Esses alunos teriam problemas, por exemplo, para ler uma obra literária ou um periódico mais denso.

Não obstante, nos PCN de Língua Portuguesa dos terceiro e quarto ciclos (1998, p. 20), o objetivo do ensino e da aprendizagem de Língua Portuguesa seja descrito como:

[...] aprender não somente palavras e saber combiná-las em expressões complexas, mas apreender pragmaticamente seus significados culturais e, com eles, os modos pelos quais as pessoas entendem e interpretam a realidade e a si mesmas.

Os dados obtidos por ambos os instrumentos de avaliação do ensino comentados acima (e constatados pela maioria dos professores em sala de aula) demonstram uma defasagem muito grande em relação àquilo que a lei garante como direito fundamental de todo brasileiro: aprender a ler e a escrever.

Embora essa questão seja extremamente complexa e passe necessariamente por questões alheias à escola, cabe a ela, em última instância, e, em particular, à disciplina de Língua Portuguesa, procurar meios para sanar o problema do baixo letramento de nossos alunos.

Considerando-se que Língua Portuguesa, ao lado de Matemática, é a matéria escolar com maior carga horária no país, resta saber o que se ensina nesse tempo? Gramática. Segundo Neves (2003, p.12-14), em pesquisa realizada por meio de questionários entregues a 170 professores de Língua Portuguesa de $1^{\circ}$ e $2^{\circ}$ graus (hoje, ensino Fundamental e Médio), mais de $90 \%(95,32 \%)$ do tempo total do programa dessa disciplina é gasto com gramática, preferencialmente na execução de exercícios de reconhecimento e classificação de palavras e estruturas $(75,56 \%)$. 
Em um estudo mais recente realizado por Semeghini-Siqueira (2006a) sobre os dados coletados em relatórios de estágios de observação de aulas de Português à disciplina de Metodologia do Ensino de Português da Universidade de São Paulo, a autora chega à conclusão de que cerca de $60 \%$ do tempo das aulas de Língua Portuguesa são gastos com exercícios gramaticais do tipo metalingüístico. Tais exercícios são apontados por Possenti (1996, p. 54), Geraldi (2002, p.129), Franchi (1991, p.15) e Travaglia (1996, p.101) como ineficientes no sentido de melhorar habilidades de compreensão da língua. Nas palavras de Franchi (1991, p. 20):

Antes de saber o que é um substantivo, um adjetivo, um advérbio, é preciso ter-se servido efetivamente dessas distinções gramaticais no trabalho de construção e reconstrução das expressões. Antes de aprender uma classificação das orações subordinadas (geralmente via memorização de listas de conjunções ou perguntilhas adrede preparadas), é preciso ter participado longo tempo do jogo de integrá-las umas nas outras, pelos mais diferentes procedimentos $[\ldots]$

A tais considerações, Travaglia (1996, p. 101) acrescenta:

[...] tais regras e exemplos (sobre o ensino da gramática prescritiva) são repetidos anos a fio como formas "corretas" e "boas" a serem imitadas na expressão do pensamento. Nas aulas há uma ausência quase total de atividades de produção e compreensão de textos.

Assim, não só esses autores criticam a forma como a gramática tem sido abordada em sala de aula, como também propõem uma outra maneira de seu ensino. Para eles, gramática, portanto, deixaria de ser entendida apenas como gramática prescritiva, normativa, atrelada à norma culta e à língua padrão e passaria a ser "[..] o estudo das condições lingüísticas da significação [..]" (FRANCHI, 1991, p. 32).

Duas outras constatações importantes podem ser deduzidas dessa definição de gramática escrita por Franchi (1991): que qualquer falante da língua domina a gramática; e que a gramática é um recurso a serviço do sentido, pois o falante ou escritor a empregará para comunicar suas idéias. Portanto,

(1) basta ser falante do português para perceber que a frase "menino o pato não é" não é gramatical. Para Possenti (1996, p. 30): 
Saber falar significa saber uma língua. Saber uma língua significa saber uma gramática. Saber uma gramática não significa saber de cor algumas regras que se aprendem na escola, ou saber fazer algumas análises morfológicas e sintáticas. Mais profundo do que esse conhecimento é o conhecimento (intuitivo ou inconsciente) necessário para falar efetivamente a língua.

Conseqüentemente, cabe à escola ensinar ao aluno o que ele ainda não sabe. Para tanto é necessário que seja realizado uma avaliação para verificar qual a capacidade de uso da língua pelo aluno "real". Esse é o objetivo da Avaliação Diagnóstica e Formativa (SEMEGHINISIQUEIRA, 1997, p. 8).

(2) Se o propósito do ensino da gramática está em instrumentalizar o aluno no sentido de torná-lo capaz de produzir textos, quer sejam orais ou escritos, isso significa que a gramática tem uma função importante dentro do processo de reescrita desse texto na medida em que aponta para melhores usos dos recursos da língua. Para isso, há a necessidade de, então, se recontextualizar não só o que se entende por gramática, mas também de como ela deve ser entendida/ensinada. Semeghini-Siqueira (1997, 2005, 2006c) propõe o trabalho com três "tipos" de gramática, que serão explicitados no capítulo 4, a saber: GRAMÁTICA 1, relacionada às atividades lingüísticas; GRAMÁTICA 2, às atividades epilingüísticas e GRAMÁTICA 3, às metalingüísticas.

Por meio dessa diferenciação de propostas para cada um dos "tipos" de gramática, pode-se elaborar atividades que sejam mais condizentes com as necessidades do aluno e mais adequadas ao desenvolvimento da escrita.

O uso de atividades epilingüísticas, relacionado à GRAMÁTICA 2, representa um ganho substancial ao de atividades metalingüísticas, uma vez que "[...] trata-se de uma atividade que toma a própria linguagem como objeto de operações transformadoras. O objetivo é aprender a usar os recursos expressivos da língua" (SEMEGHINI-SIQUEIRA, 1997, p. 7). Ao fazer com que o aluno reflita sobre as melhores formas de se dizer o que se quer dizer, em momentos destinados à reescrita, o aluno estará realizando atividades epilingüísticas.

Ao sugerir que as atividades epilingüísticas podem ser trabalhadas na forma de brincadeiras com linguagem, nas quais se "[...] compara as expressões, transforma-as, experimenta novos modos de construção canônicos ou não, brinca-se com a linguagem, investe as formas 
lingüísticas de novas significações [...]” (FRANCHI, 1991, p.36), o autor aponta para outra questão: o uso de atividades lúdicas no ensino de Língua Portuguesa.

Uma proposta que engloba esses tipos de atividades em larga escala e de forma bem sucedida é a adotada nas aulas de Língua Estrangeira, notadamente de língua inglesa ministradas nos chamados cursos de idiomas ${ }^{10}$. Ainda que haja uma variedade bastante grande de métodos oferecidos por tais escolas, quase a totalidade atualmente adota os princípios da Abordagem Comunicativa. Segundo essa linha de abordagem, o ensino de idiomas:

[...] é aquele que não toma as formas da língua descrita nas gramáticas como modelo suficiente para organizar as experiências de aprender outra língua, mas sim, aquele que toma unidades de ação feitas com linguagem como organizatórias das amostras autênticas de língua-alvo que se vão oferecer ao aluno-aprendiz. (ALMEIDA FILHO, 1993, p.47-48)

Nota-se, por meio dessa descrição, que, em nenhum momento, exercícios de classificação ou identificação de itens de linguagem foram mencionados - atividades essas tão comuns, ocupando $39,71 \%$ e 50,15\% da aula, respectivamente, segundo Neves (2003, p.10 e 11), no ensino de Língua Portuguesa. Trata-se, pois, de uma abordagem que privilegia atividades lingüísticas e epilingüísticas. Resta, porém, uma questão: como tais atividades são trabalhadas?

Embora não seja possível relacionar todas as maneiras pelas quais tais atividades aparecem em sala de aula de Língua Estrangeira, dado o volume das contribuições, Littlewood (1990, p. 2) identificou dois grupos de atividades: as "atividades comunicativas funcionais"11 e as "atividades sociais de interação." 12 As primeiras são descritas como "[...] atividades em que o professor apresenta situações nas quais os alunos terão que trocar informações ou resolver um problema." ${ }^{13}$ (LITTLEWOOD, 1990, p. 22). Caracterizam-se por:

[...] tarefas como a comparação de imagens para a percepção de similaridades, discussão sobre qual a sequiência provável dos eventos que ocorrem em um conjunto de imagens, encontrar o que falta em um mapa ou

\footnotetext{
${ }^{10}$ Vale ressaltar, porém, que “[...] os cursos de idiomas são caracterizados como livres pois seus certificados não são reconhecidos pelo Ministério da Educação e Cultura (MEC). Com isso, não existe um órgão que regulamente a abertura dos mesmos." (KANIKADAN; LIMONGE-FRANÇA; 2008).

11 “functional communication activities”" (tradução nossa).

12 "social interaction activities" (tradução nossa).

13 "[...] activities in which the teacher structures the situation so that the learners have to overcome an information gap or solve a problem." (tradução nossa).
} 
imagem, um aluno sem ver o outro dando instruções sobre como fazer um desenho ou uma figura, ou como se completa um mapa, seguir instruções, e resolver problemas por meio da socialização de informações. ${ }^{14}$ (RICHARDS; RODGERS, 2001, p. 166)

Já, as "atividades sociais de interação" incluem "[...] conversas e discussões, diálogos e teatralizações, simulações, situações engraçadas, improvisações e debates [...] [nas quais] se espera que os alunos façam escolhas acerca da linguagem utilizada tendo em vista aspectos tanto funcionais quanto sociais. Desarte, sua produção lingüística será avaliada em relação à sua aceitabilidade social e eficiência funcional."15 (LITTLEWOOD, 1990, p. 43)

Não por acaso, as idéias defendidas por Travaglia (1996) acerca de uma aprendizagem produtiva se assemelham, grosso modo, às defendidas pela Abordagem Comunicativa, dado o fato de o autor ter se servido, entre outros, do referencial teórico criado por pesquisadores ligados ao movimento de renovação dos estudos da linguagem da década de 70 que culminou na perspectiva comunicativa de ensino de línguas: Halliday, McIntosh e Strevens, citados diversas vezes por Tavaglia (1996, p.38-40; 51).

Se, por um lado, percebemos uma afinidade maior dos primeiros exercícios às atividades lingüísticas e dos últimos, às epilingüísticas, é bem verdade que ambos possuem um componente lúdico bastante presente. Como apontam Wright, Betteridge e Buckerby (1993, p. I), autores renomados de coletâneas de sugestões de jogos para o ensino de inglês:

Jogos ajudam e encorajam muitos alunos a manter o interesse e a trabalharem. Jogos também ajudam os professores a criarem contextos nos quais o uso da língua é necessário e significativo. Os alunos querem participar e, para isso, precisam compreender o que os outros estão dizendo ou escreveram, e eles precisam falar ou escrever para expressarem seu ponto de vista ou darem informações ${ }^{16}$.

\footnotetext{
14،[...] tasks as learners comparing sets of pictures and noting similarities; working out a likely sequence of events in a set of pictures; discovering missing features in a map or picture; one learner communicating behind a screen to another learner and giving instructions on how to draw a picture or shape, or how to complete a map; following directions; and solve problems from shared clues." (tradução nossa).

15 "[...] conversation and discussion sessions, dialogues and role plays, simulations, skits, improvisations, and debates.\{...\} The learner is expected to let social as well as functional considerations affect his choice of language. Accordingly, the language he produces will be evaluated in terms of its social acceptability as well as its functional effectiveness.” (tradução nossa)

16 "Games help and encourage many learners to sustain their interest and work. Games also help the teacher to create contexts in which the language is useful and meaningful. The learners want to take part and in order to do so must understand what the others are saying or have written, and they must speak or write in order to express their own point of view or give information." (tradução nossa)
} 
Portanto, para esses autores, os jogos adaptados ao ensino de idiomas são ideais para a criação de um ambiente de ensino e aprendizagem em que a prática da língua - feita de forma prazerosa - aparece conciliada a situações em que os alunos necessitam interagir de maneira mais livre para poderem realizar interações que têm uma motivação pessoal verdadeira. Longe de serem apenas momentos de relaxamento e diversão, tais atividades lúdicas consistem em tarefas importantes a serem executadas em conjunto por seus participantes/alunos. Trata-se, pois, de um recurso bem sucedido que privilegia principalmente a realização de atividades lingüísticas e epilingüísticas, em detrimento das metalingüísticas (ainda que nada as impeça de serem suportes para um desses jogos).

Por estabelecer a união entre a prática e o contexto, o uso desse tipo de jogo é largamente difundido no ensino de idiomas, notadamente nos institutos de idiomas disponíveis em São Paulo. E no ensino de Língua Portuguesa? Como é a sua utilização?

Com relação ao ensino de crianças pequenas, uma experiência no Pará aponta para o sucesso do emprego de jogos no ensino de Língua Portuguesa. No município de Vigia, no norte do estado, a escola de melhor desempenho no Prova Brasil 2005 de toda a região Norte do país, a Escola Municipal Cândido Vilhena, com 208 pontos na avaliação de Português (para a 4 . Série), a $13^{\mathrm{a}}$ mais bem colocada na série em todo o país, está em uma região muito pobre, com menos de $50 \%$ das residências com água e esgoto. Entre os projetos pedagógicos que a diretora Nazareth Vilhena destacou em entrevista ao site Portal da Revista da Educação, estão a formação continuada de professores e a "utilização de jogos didáticos no processo de alfabetização, como alternativa ao quadro negro.” (BARROS, 2006)

Com relação ao ensino Fundamental II, porém, há pouca literatura disponível que faça qualquer referência ao uso de jogos no ensino e aprendizagem de Língua Portuguesa. Assim sendo, porque não expandir a experiência bem sucedida no Fundamental I e no ensino de idiomas ao ensino de Português no Fundamental II, já que:

(1) Ainda que a forma de aquisição das modalidades oral e escrita de uma língua materna seja muito distinta à de um segundo idioma - e suas finalidades e propósitos sejam completamente diferentes - ambos possuem parte de seus objetivos semelhantes, isto é, proporcionam condições de interação entre as pessoas. 
(2) Assim como ocorre no ensino de Língua Portuguesa, houve também uma crença, durante muitos anos, de que o ensino da gramática de uma língua estrangeira bastava, por si só, para levar o aluno ao domínio do idioma em questão. Longe do desuso, essa prática pedagógica pode ainda ser observada na maioria das aulas do ensino regular das escolas de nosso país (CARRIEL, 2002, 91).

(3) Embora o Inglês seja matéria obrigatória para todos os alunos da rede oficial de ensino, um número cada vez maior de alunos matricula-se em institutos de idiomas. O que leva esses alunos a pagarem escolas paralelas para freqüentarem aulas que já são ministradas na escola regular? Observações realizadas por Carriel $(2002,106)$ em uma escola pública de São Paulo em situação de estudo etnográfico apontam que "[...] os alunos que estudavam inglês em institutos [de idiomas] eram admirados e respeitados por seus colegas. Como detinham o conhecimento, sempre eram requisitados [...]", denotando a crença de que nesses cursos extracurriculares aprenda-se realmente o idioma. O principal motivo sugerido pela autora (2002, 201-2005) é que, por dominarem o uso competente das quatro habilidades - falar, ouvir, ler, e escrever, e não somente da gramática, como ocorre na escola regular, esses alunos estão realmente mais bem preparados para compreenderem o idioma em foco. Isso significa que o ensino da gramática não é visto por tais alunos como suficiente para o domínio de um idioma.

(4) Apesar de toda a variedade metodológica que existe entre as escolas de inglês que funcionam no mercado brasileiro, alguns elementos são comuns em suas rotinas procedimentais. Entre eles, o uso de jogos para facilitar a aprendizagem parece ser, ao lado da prática oral efetiva, o elemento mais importante entre todas essas metodologias. $\mathrm{O}$ uso consistente e contextualizado desse recurso propicia a interação verdadeira entre os alunos, além de criar objetivos imediatos para a aprendizagem.

Por todos esses motivos, não se trata de reduzir um tipo de aprendizagem ao outro, mas de compartilhar experiências. Antes, propõe-se a descompartimentalização de conhecimentos em prol de uma busca para uma melhor forma de se superar o desafio de ensinar nossos alunos a “[...] ler e a escrever, discutir e reescrever, reler e reescrever mais para escrever e ler de forma sempre mais sofisticada [...]" (POSSENTI, 1996, p.33). 
Em função do exposto acima, formula-se a seguinte pergunta: como poderiam ser aproveitados os conhecimentos já elaborados sobre a utilização do lúdico no ensino e aprendizagem de línguas (notadamente em Língua Inglesa) para proporcionar maior interesse por parte dos alunos em Língua Portuguesa no Fundamental II?

\subsection{Objetivos}

O objetivo central deste trabalho é propor uma forma alternativa de ensino e aprendizagem de Língua Portuguesa cujo foco é o desenvolvimento efetivo das habilidades de leitura, escrita e oralidade de alunos que cursam o Fundamental II. Para isso, procurou-se priorizar a realização de atividades lingüísticas e epilingüísticas dentro de contextos lúdicos como maneira de motivar a participação e o interesse dos alunos envolvidos pelo projeto.

Tendo em vista outras finalidades específicas, pretende-se:

- refletir sobre aspectos da inserção do lúdico em sala de aula e suas implicações no processo de ensino e aprendizagem de línguas, tanto estrangeira quanto materna;

- analisar, a partir de um estudo exploratório, como tem sido a prática efetiva de professores de Língua Portuguesa e de Língua Inglesa com relação ao uso de jogos em sala de aula;

- verificar, por meio de minicurso ministrado a alunos da rede pública de ensino, as possibilidades reais de sucesso de uma metodologia de ensino de Língua Portuguesa cuja prática considere as atividades lúdicas como uma alternativa ao excesso de atividades metalingüísticas, sempre tendo como objetivo a leitura e produção de textos. 


\subsection{Proposta metodológica}

Duas opções metodológicas distintas foram realizadas para tornar viáveis os objetivos deste trabalho. Assim, em uma primeira etapa, recorreu-se a pesquisa de cunho Etnográfica Investigativa, e, posteriormente, foi realizada uma Segunda Entrada em Campo do tipo Investigação/ação.

Ainda que linhas diferentes dentro da etnografia tenham pautado cada uma de suas partes, a opção pela etnográfica foi central para esta pesquisa, uma vez que não é possível discutir sobre o modo como as atividades de caráter lúdico são realizadas no contexto da sala da aula sem se estar presente enquanto ocorrem.

A opção pela denominação de "entrada em campo" e pesquisa de "cunho etnográfico", ao invés de "pesquisa etnográfica" propriamente dita ocorreu em virtude do tempo limitado de sua realização. Porém, para os propósitos aqui definidos, sua duração foi considerada adequada.

As questões apresentadas no quadro 1 orientaram a pesquisadora na realização do trabalho de campo:

(1) Que forma de interação se estabelece entre os participantes (tanto entre os alunos quanto entre alunos-professor)?

(2) Em que momento da aula a atividade acontece?

(3) Qual o tempo de duração da atividade em relação ao tempo ocupado pelas demais atividades programadas na aula?

(4) Qual o objetivo da atividade?

(5) Qual o papel dos alunos e do professor na atividade?

\section{Quadro 1 - Questões orientadoras da ENTRADA EM CAMPO}

Outro benefício da escolha pela abordagem etnográfica foi a possibilidade que esse recurso trouxe ao pesquisador de revelar informações implícitas sobre a cultura dos sujeitos observados, já que muitas dessas informações permanecem em um nível não consciente para os próprios sujeitos. Por essa razão, tal conhecimento se torna impossível de ser resgatado por 
meio de métodos que se ocupem apenas em executar entrevistas ou analisar dados generalizantes sobre a população estudada (ERICKSON, 1989, p. 205).

Há, porém, várias concepções do termo "etnografia", cada qual de acordo com o entendimento de uma das diversas correntes ideológicas que compõem os estudos antropológicos (ERICKSON, 1989, p.196).

Assim, enquanto este trabalho consistiu apenas em observação, adotou-se como referencial teórico o ponto de vista da Etnografia Interpretativa, defendido por pesquisadores como Geertz (1995), Erickson (1989) e Rockwell (1986), entre outros. Em um segundo momento, quando a pesquisadora tomou parte do processo de ensino e aprendizagem, recorreu-se à Investigação-ação, cujo referencial teórico contempla a participação do pesquisador como ator do próprio processo estudado.

Quanto à perspectiva da Etnografia Interpretativa, o uso do termo “interpretativo" se dá porque seu objetivo é o estudo do significado das relações sociais estabelecidas em uma determinada cultura e local, sob a perspectiva de um observador que não se pretende isento de seus próprios pré-conceitos (GEERTZ, 1995, p. 15-20). O termo foi preferido por autores como Erickson (1989) e Geertz (1995) porque abrange, inclusive, outras variedades de pesquisas de caráter não exclusivamente qualitativo, podendo conter instrumentos quantitativos. Porém, mais importante do que generalizações estatísticas, esse estudo visa fatores universais concretos, aqueles aos quais se chegam por meio da análise de um caso concreto em profundidade (ERICKSON, 1989, p. 196).

A chave para a compreensão de algo de interesse para pesquisas etnográficas (e as de natureza etnográficas), portanto, não está nos dados, mas naquilo que é insinuado em uma descrição que o autor chamou de "densa". A objetividade da observação é entendida como algo impossível, já que se trata de um ponto de vista a partir de agente sobre uma cultura outra que não a sua, a do ator. Portanto, tal descrição é sempre ficção, no sentido de que traz uma construção elaborada com fatos recolhidos sob a orientação de uma determinada perspectiva (GEERTZ, 1995, p. 20).

Outro ponto muito importante para Geertz (1995, p. 32) é que toda descrição antropológica é microscópica, isto é, feita dentro de um recorte bastante criterioso da realidade social. Assim, 
embora haja a tentação de se querer compreender o todo pela parte, só é possível entender a parte em que se estuda, e isso não quer dizer que se compreenda aquele lugar de estudo, mas aquilo que se queira estudar naquele lugar, o que a torna, portanto, circunstanciada, isto é, dependente daquele contexto.

Rockwell e Ezpeleta $\left(1986^{17}\right.$ apud TELLES, 2005, p.12, 13) abordam ainda outra característica importante da Etnografia Interpretativa:

A etnografia como procedimento de pesquisa não requer a definição inicial de um modelo teórico acabado que funcione como marco, ou seja, que delimite o processo de observação, exigência, por exemplo, das pesquisas quantitativas e experimentais, nas quais a operacionalização das variáveis é necessária. Dado o vínculo estreito entre observação e análise, a definição de categorias teóricas de diferentes níveis vem se construindo no processo de pesquisa etnográfica.

Por outro lado, Erickson (1989, p. 258) chama à atenção para a necessidade de um modelo teórico sólido que possa embasar as considerações e as conclusões advindas da interpretação dos dados recolhidos: "La redacción de las notas estimula la memoria y le permite al investigador agregar información a la contenida em las anotaciones iniciales. También estimula la inducción analítica y la reflexión sobre los aspectos teóricos y la bibliografía pertinentes."

Assim, a questão não é ter uma pergunta fechada antes de entrar em campo, mas sim, ter perguntas que orientem o trabalho a princípio e, durante as observações, estar aberto para encontrar provas que refutem suas pressuposições e gerem novas perguntas.

Quanto à abordagem chamada de Investigação-ação, mesmo havendo uma grande diversidade de concepções teóricas a seu respeito, alguns pontos em comum orientam a sua prática. Segundo Gómez, Flores e Jiménez (1999, p. 52), a Investigação-ação tem como premissas básicas:

[...] destacar el carácter preponderante de la acción, como definitorio de este método de investigación. Esta dimensión se concreta en el papel activo que asumen los sujetos que participan en la investigación, la cual toma como inicio los problemas surgidos de la práctica educativa, reflexionado

\footnotetext{
${ }^{17}$ ROCKWELL, E. R, EZPELETA, J. Reflexiones sobre el processo etnográfico. México: Departamento de Investigações Educativas, Mimeo, 1986.
} 
sobre ellos, rompiendo de esta forma con la dicotomía separatista teoría/práctica. [...] Como investigación se concibe desde una perspectiva [...] defendiendo la unión de investigador/investigado, forjando un nuevo modelo de investigador que realiza su trabajo de forma sistemática a través de un método flexible, ecológico y orientado a los valores.

Destarte, a intervenção no meio é o princípio fundamental dessa linha investigativa, uma vez que é por meio do envolvimento com a comunidade que ocorre a busca por uma solução para a questão-problema que motivou a pesquisa.

Nesse sentido, a Investigação-ação tende a ser a abordagem preferida especialmente por aqueles que estão diretamente relacionados ao meio em que realizam sua pesquisa.

\subsection{Primeira Entrada em Campo: pesquisa de cunho etnográfico- investigativo}

A Primeira Entrada em Campo consistiu na observação de aulas de Português da $6^{\text {a }}$ série e de Inglês extracurricular, que ocorreu uma vez por semana em um colégio particular de São Paulo durante dois meses, em 2005. Foram realizadas também entrevistas informais com ambas as professoras e com os 11 alunos que tomaram parte da pesquisa.

\subsubsection{Local em que ocorreu a pesquisa}

O colégio em que foi realizada a primeira parte da Entrada em Campo faz parte da rede particular de ensino do Estado de São Paulo, localizado em um bairro de classe média, na zona sul da capital, desde que foi fundado, em 1954.

Quando o estudo foi iniciado, a pesquisadora já lecionava, como funcionária do curso de inglês extracurricular, há três meses nesse estabelecimento de ensino. Se, a princípio, o interesse pela escola se deu pelo acesso facilitado aos alunos e ao corpo docente, o que realmente o definiu como lugar para a pesquisa foi o fato de serem praticamente os mesmos alunos que freqüentavam a aula de Português e a de Inglês extracurricular. Por esse motivo, 
foi possível observar como tais alunos se comportavam em um e em outro momento, segundo as atividades que lhes eram propostas.

Em termos gerais, o colégio atende a, aproximadamente, 1500 alunos por ano, distribuídos em três períodos, manhã, integral e noite. No período noturno funcionam paralelamente cursos de formação superior e de EJA (Educação para jovens e adultos). Durante o dia, a clientela é formada por crianças vindas do mesmo bairro em que se localiza a escola e de outros bairros de classe média vizinhos. São, quase a metade deles (37\%), filhos de ex-alunos. À noite, uma população muito mais pobre, de classe média-baixa e baixa, freqüenta a escola, na sua grande maioria, formada por adultos residentes em outras regiões da cidade menos privilegiadas. $\mathrm{O}$ EJA é gratuito, realizado como obra social.

O instituto de idiomas da qual a professora de Inglês (e a pesquisadora) fazia parte também fica na zona sul de São Paulo, próximo ao colégio pesquisado, mas em uma área mais sofisticada da região. Na época, eram aproximadamente 3.500 alunos, distribuídos em 16 salas de aula, e três colégios para os quais prestava serviços, sendo que um deles era justamente aquele pesquisado.

As salas de aula são bastante grandes para um curso de inglês (média de 18 alunos) e a clientela é bastante variada. Sabe-se, porém, que em alguns horários, principalmente à tarde, as turmas são compostas por crianças e adolescentes de famílias de classe média e média-alta e que, de manhã e a noite, os alunos são majoritariamente adultos, cujos níveis sociais se alteram quase que similarmente aos do estágio em que se encontram: classe média/médiabaixa nos estágios mais básicos, classe média/ média-alta, nos mais avançados.

$\mathrm{Na}$ condição de professora desse instituto de idiomas, a pesquisadora obteve acesso, embora com alguma restrição, tanto às classes que desejava, quanto aos materiais pedagógicos (livro do aluno, livro do professor), aos documentos oficiais (Projeto Pedagógico, publicações internas, circulares para alunos, programa da disciplina) e aos funcionários da escola (professores, coordenadora, secretárias e inspetores). Não foi possível, porém, falar com a diretora. 


\subsubsection{Sujeitos da pesquisa}

Participaram dessa primeira etapa duas professoras - uma de Português, contratada pelo colégio onde a Entrada em Campo ocorreu, e outra, de Inglês ${ }^{18}$, técnica em idiomas da escola de inglês que se utiliza do espaço e dos alunos da escola regular para realizar suas aulas; e 11 alunos da $6^{\text {a }}$. série do Ensino Fundamental II.

A escolha por esses sujeitos deveu-se ao fato de serem, a maioria deles, os mesmos alunos que freqüentavam a aula de Inglês, oferecida pelo curso de idiomas referido acima, e de Português, da $6^{\circ}$. série.

Os alunos-sujeitos são todos do período integral, todos entre 11 e 12 anos, cujo perfil sócioeconômico é semelhante àquele que já foi exposto anteriormente sobre os alunos que freqüentam a escola de manhã e de tarde.

\begin{tabular}{|c|c|c|c|}
\hline Alunos/Sala & $\begin{array}{c}\text { SALA DE INGLÊS } \\
\text { EXTRACURRICULAR }\end{array}$ & $\begin{array}{c}\text { SAla de } \\
\text { Português }\end{array}$ & $\begin{array}{c}\text { ALUNOS- } \\
\text { SUJEITOS DA } \\
\text { PESQUISA }\end{array}$ \\
\hline MENINOS & 9 & 7 & 4 \\
\hline MENINAS & 7 & 12 & 7 \\
\hline TOTAL & 16 & 19 & 11 \\
\hline
\end{tabular}

Tabela 1 - Relação de alunos por sala no colégio onde ocorreu a pesquisa de campo

Lecionando há apenas um ano e meio nessa escola, Marta tem 47 anos, dos quais, 18 foi secretária e 13, professora. Atualmente, leciona nas $6^{\text {as }}$ séries do colégio pesquisado e continua como professora em uma escola estadual, onde começou sua carreira, no horário noturno. Segundo ela, gosta muito de dar aulas na rede pública porque se sente mais valorizada por aqueles alunos, o que leva a pensar que no colégio em questão a professora não sentia o mesmo nível de satisfação pessoal.

Quanto à Ingrid, foi colega de trabalho da pesquisadora por um ano. Por esse motivo, havia uma liberdade maior em suas respostas, ainda que se percebesse seu constrangimento quando

\footnotetext{
${ }^{18}$ Os nomes fictícios Marta e Ingrid, respectivamente, foram aqui lhes atribuído para que suas identidades verdadeiras fossem preservadas.
} 
teve suas aulas observadas. Sem uma formação universitária específica (fez técnico em secretariado na década de 80), a técnica em idiomas aprendeu inglês na própria instituição em que no momento da pesquisa estava trabalhando, e em viagens que fez à Europa. Aos 45 anos, lecionou em dois momentos distintos nessa escola - que foi seu único empregador na área da Educação.

Em muitas conversas anteriores à observação das aulas, deixou entrever a desilusão que enfrentava com o trabalho. Segundo ela, na primeira vez que foi contratada, se sentia "muito mais valorizada", enquanto "hoje, me sinto mais uma das empregadas domésticas de meus alunos".

\subsubsection{Procedimentos para a coleta de dados}

Como o método escolhido nessa etapa pressupõe, foram realizadas observações de ambas as aulas uma vez por semana, nas quais se procurou anotar tudo o que parecia relevante: falas da professora e dos alunos, comentários paralelos durante a aula, exercícios passados na lousa, seqüência das atividades realizadas em aula, instruções para a realização das atividades, matéria utilizada no livro didático, envolvimento e interesse dos alunos durante as atividades, movimentações na sala e qualquer outra ocorrência que pudesse, em um segundo momento, o da reflexão, fazer algum sentido.

Nessa etapa, os dados foram coletados entre 22 de maio e 25 de agosto de 2006, sendo que o mês de julho inteiro foi de recesso escolar.

\subsection{Segunda Entrada em Campo: Investigação-ação}

A segunda etapa da Entrada em Campo consistiu na realização, pela pesquisadora, de um minicurso de oralidade, leitura e escrita oferecido a alunos de uma escola da rede pública da zona sul de São Paulo, situada dentro da Favela da Paz. 
O trabalho com nove alunos que se dispuseram a participar do projeto foi realizado durante dois meses, em 2006.

\subsubsection{Local em que ocorreu a pesquisa}

Localizada em uma das muitas favelas da zona sul da capital, o colégio da rede pública municipal onde foi realizada a segunda etapa da Entrada em Campo foi escolhida por dois motivos práticos: sua proximidade física da casa da pesquisadora e o conhecimento prévio do trabalho realizado pela escola dentro da comunidade em que se encontra. A rigor, trata-se da única presença do poder público dentro da própria favela, que carece de esgoto e iluminação pública em suas ruelas, mesmo sendo vizinha de um dos bairros mais ricos da capital, o Morumbi.

Inaugurada no governo Jânio Quadros, a EMEF presta serviços exclusivamente à população da favela. Tendo consciência da importância de seu papel social, a escola participa de todos os projetos de melhoria da qualidade de ensino e inclusão social da prefeitura: abre suas portas de fim de semana à comunidade, oferece cursos alternativos nas férias, realiza passeios freqüentemente a parques, museus e eventos culturais na cidade, faz parceria com uma ONG, que oferece aulas gratuitas de xadrez, e realiza um trabalho de inclusão com alunos com deficiência mental e/ou física.

Seus aproximadamente 660 alunos se dividem em três períodos: manhã, tarde e noite; sendo as aulas da manhã freqüentadas por alunos do Fundamental I; da tarde, do Fundamental II e da noite, do EJA. O minicurso ocorreu entre o primeiro e o segundo período, das 11:00 às 13:00, duas vezes por semana.

\subsubsection{Sujeitos da pesquisa}

Os alunos que se dispuseram a participar do minicurso eram provenientes da $6^{\mathrm{a}}, 7^{\mathrm{a}}$ e $8^{\mathrm{a}}$ séries, sendo que apenas um aluno da $7^{\mathrm{a}}$ desistiu depois da primeira aula, somando 9 alunos freqüentes. 


\begin{tabular}{c|c|c|c}
\hline ALUNOS/SÉRIE & $\mathbf{6}^{\mathrm{a}}$. SÉRIE & $\mathbf{7}^{\mathrm{a}}$. SÉRIE & $\mathbf{8}^{\mathrm{a}}$. SÉRIE \\
\hline MENINOS & 1 & 2 & 1 \\
\hline MENINAS & 3 & 1 & 2 \\
\hline TOTAL & 4 & 3 & 3 \\
\hline
\end{tabular}

Tabela 2 - Relação de alunos por série da Segunda Entrada em Campo

Suas idades variavam entre 13 anos e 15 anos. Todos eram moradores da favela e suas famílias recebiam algum auxílio do governo para complementar a renda mensal, ainda que a maioria dos pais e mães trabalhasse fora. Eram seguranças, vendedores ambulantes, porteiros, policiais civis, empregadas domésticas e recepcionistas, entre outras profissões de baixa remuneração. Esses alunos não possuíam computador em casa, mas todos acessavam a Internet pela escola. Com exceção de uma menina, todos são afro-descendentes. Dos 3 alunos que estavam para concluir a $8^{\mathrm{a}}$ série naquele ano, dois estavam já a procura de emprego.

Todos os alunos que frequientaram as aulas do minicurso o fizeram por vontade própria. Não houve em momento algum coerção de qualquer espécie por parte nem da direção, nem do corpo docente para que esses adolescentes viessem às aulas. O próprio ato de inscrição no curso se deu também respeitando suas vontades individuais, uma vez que foi deixada na secretaria uma lista que a ser preenchida pelos alunos interessados.

\subsubsection{Procedimentos para a coleta de dados}

O procedimento de coleta de dados consistiu em três tipos de anotações: a seqüência didática criada para o minicurso, as observações anotadas imediatamente após cada aula e as produções dos alunos, nas diversas etapas do trabalho realizado.

As aulas foram ministradas entre os dias $1^{\circ}$ de novembro e 13 de dezembro de 2006 , em um total de 22 horas.

A proposta das atividades realizadas, assim como as constatações da Avaliação Diagnóstica e Formativa, a sequiência didática, as observações sobre as aulas e seus resultados estão no capítulo 6. 
O LÚDICO 


\section{O LÚDICO}

Por inverossímil que pareça, ninguém ensaiara até então uma teoria geral dos jogos.

O babilônio não é um ser especulativo.

Jorge Luis Borges ${ }^{19}$

A aparente simplicidade do uso cotidiano da palavra "jogo" esconde uma complexidade conceitual comparada por Wittgenstein (1975, p. 42-43) à própria dificuldade de se definir a linguagem.

A diversidade dos processos aos quais atribuímos esse nome é tão grande que o clichê "a vida é um jogo" parece ser a máxima por detrás da lógica de tal denominação - ainda que, evidentemente, “a vida não é, não pode ser, apenas um jogo” (MACHADO, 2006, p. 106). O mesmo ocorre com "brinquedo", "brincadeira" e "lúdico".

Assim, este capítulo inicia-se com a distinção do que é "lúdico", "jogo", "brinquedo" e "brincadeira", para, posteriormente, discutir-se as implicações de suas características na Educação.

\subsection{Jogo, lúdico, brinquedo ou brincadeira?}

Ao procurar uma analogia que explique o funcionamento da linguagem humana, Wittgenstein (1975, p. 42, 43) recorre à comparação desta com o jogo:

Considere, por exemplo, os processos que chamamos de "jogos". Refiro-me a jogos de tabuleiro, de cartas, de bola, torneios esportivos, etc. O que é comum a todos eles? Não diga: "Algo deve ser comum a eles, senão não se chamariam jogos" - mas veja se algo é comum a todos. - Pois, se você os contemplar, não verá na verdade algo que seja comum a todos, mas verá semelhanças, parentescos, e até toda uma série deles. Como disse: não pense, mas veja! - Considere, por exemplo, os jogos de tabuleiro, com seus múltiplos parentescos. Agora passe para os jogos de cartas: aqui você encontra muitas correspondências com aqueles da primeira classe, mas

\footnotetext{
${ }^{19}$ BORGES, J. L. A loteria em Babilônia. In: Ficções. Globo: 2005, p. 78
} 
muitos traços comuns desaparecem e outros surgem. Se passarmos aos jogos de bola, muita coisa comum se conserva, mas muitos se perdem. - São todos "recreativos"? Compare o xadrez com o jogo da amarelinha. Há em todos um ganhar e um perder ou uma concorrência entre os jogadores? Pense nas paciências. Nos jogos de bola há um ganhar e um perder, mas se a criança atira a bola na parede e a apanha outra vez, este traço desaparece. Veja que papéis desempenham, a habilidade e a sorte. E como é diferente a habilidade no xadrez e no tênis. Pense agora nos brinquedos de roda: o elemento de divertimento está presente, mas quantos dos outros traços característicos desaparecem! E assim podemos percorrer muitos, muitos outros grupos de jogos e ver que semelhanças surgirem e desaparecerem.

E tal este é o resultado desta consideração: vemos uma rede complicada de semelhanças que se envolvem e se cruzam mutuamente. Semelhanças de conjunto e de pormenor. Não posso caracterizar melhor essas semelhanças do que com a expressão "semelhanças de família", pois assim se envolvem e se cruzam as diferentes semelhanças que existem entre os membros de uma família: estatura, traços fisionômicos, cor dos olhos, o andar, o temperamento, etc., etc. - E digo: os “jogos” formam uma família.

A conclusão de Wittgenstein de que as semelhanças que levam à atribuição da mesma palavra a fenômenos tão distintos são da mesma ordem que as observadas em uma família aponta para uma das principais características do jogo: a dificuldade de se encontrar uma definição que consiga abarcar toda a variedade das relações humanas que se estabelecem sob sua denominação.

Sobre essa diversidade de fenômenos a que a palavra "jogo" se refere, Huizinga (2004, p. 34) relaciona ao fato de que "[...] a categoria geral de jogo não ter sido distinguida com idêntico rigor por todas as línguas, nem sempre sendo sintetizada em uma única palavra [...]” porque “[...] a abstração de um conceito geral de jogo penetrou uma cultura muito mais cedo e de maneira mais completa do que outra [...]." Além disso, "há indícios que mostram que a abstração de um conceito geral de jogo foi, em algumas culturas, tão tardia e secundária como foi primária e fundamental a função do jogo."

À dimensão cultural apontada por Huizinga, Brougère (1995, p. 16) acrescenta "a noção de jogo como conjunto de linguagem que funciona em um contexto social," de forma que "a designação não tem o objetivo de compreender a realidade visada, mas de manipulá-la simbolicamente para as necessidades da vida cotidiana", ao que o autor conclui dizendo que (BROUGÈRE, 1995, p. 29):

Certamente, deve-se estar atento à diversidade que se encontra sob o mesmo vocábulo, mas, ao mesmo tempo, levar a sério o ato social que leva a reagrupar sob o mesmo termo diferentes atividades. Deve-se pensar em 
conjunto a diversidade dos "fatos lúdicos" e a lógica da noção de jogo que se enriquece sem cessar com todos os discursos que tentam delimitar, repensar essa noção, sob o risco de se encontrar em uma posição instável em relação ao uso social. [...] Estudar o jogo é estudar fatos e, ao mesmo tempo, a denominação desses fatos. Sem a unidade da palavra jogo, por mais arbitrária que seja, não haveria estudo possível do jogo.

Assim, para Huizinga (2004, p.33), jogo é:

[...] uma atividade ou ocupação voluntária, exercida dentro de certos e determinados limites de tempo e de espaço, segundo regras livremente consentidas, mas absolutamente obrigatórias, dotado de um fim em si mesmo, acompanhado de um sentimento de tensão e de alegria e de uma consciência de ser diferente da "vida quotidiana."

Voluntário porque iniciado, sem coerção, pelos próprios participantes; limitado no tempo e no espaço no sentido de que tem um início, meio e fim - mas não uma finalidade, isto é, não se joga para atender a "[...] interesses materiais imediatos e à satisfação individual das necessidades biológicas [...]" (HUIZINGA, 2004, p. 12). Por causa de seu isolamento com relação às outras atividades cotidianas, o jogo pode ser repetido e transmitido pela memória, quando "torna-se tradição" (HUIZINGA, 2004, p. 13). Quanto às regras, Huizinga (2004, p. 14) destaca sua importância para o conceito de jogo porque são elas que determinam "aquilo que 'vale' dentro do mundo temporário por ele circunscrito" e, portanto, que ordenam a realidade dentro do jogo. A tensão é uma decorrência da regra, do superar-se dentro dos limites estabelecidos por ela, e a alegria a decorrência do sucesso dessa superação.

Outra característica importante relacionada ao jogo por Huizinga (2004, p. 8 - 11) é a nãoseriedade, sendo que o autor adverte sobre a não possibilidade da se reduzir a expressão a "o jogo não é sério", pois, para aqueles que jogam, o fazem "com um enlevo e um entusiasmo que chegam ao arrebatamento". A não-seriedade relaciona-se, nesse contexto, ao fato de que nenhuma mudança no mundo real - exterior ao jogo - advir do jogo.

No Brasil, Kishimoto (1994, p. 7) identifica que diversos estudos importantes sobre o jogo "apontam para a indiferenciação no emprego de tais termos" (jogo, brinquedo e brincadeira), sintoma "que reflete o pouco avanço dos estudos na área". Kishimoto (2001, p. 21), porém, compreende que:

O vocábulo 'brinquedo' não pode ser reduzido à pluralidade de sentidos do jogo, pois conota criança e tem uma dimensão material, cultural e técnica. 
Enquanto objeto, é sempre suporte de brincadeira. É o estimulante material para fazer fluir o imaginário infantil. E a brincadeira? É a ação que a criança desempenha ao concretizar as regras do jogo, ao mergulhar na ação lúdica. Pode-se dizer que é o lúdico em ação. Desta forma, brinquedo e brincadeira relacionam-se diretamente com a criança e não se confundem com o jogo. [grifos da autora].

Entende-se por essa afirmação que, embora "jogo", "brinquedo" e "brincadeira" não se refiram ao mesmo fenômeno, o "lúdico" perpassa a nossa compreensão dessas realidades. Similarmente, Santa (2000, p. 57) afirma que “[...] a palavra lúdico significa brincar. Nesse brincar estão incluídos os jogos, brinquedos e brincadeira, e é relativo também à conduta daquele que joga, que brinca e que se diverte."

Para Macedo, Petty e Passos (2005, p. 15-22), a presença do lúdico em uma atividade pode ser indicada pela presença de cinco fatores:

1. Prazer funcional.

2. Serem desafiadoras.

3. Criarem possibilidades ou disporem delas.

4. Possuírem dimensão simbólica e

5. expressarem-se de modo construtivo ou relacional.

Por prazer funcional, os autores entendem a alegria e a voluntariedade dos participantes de um jogo em tomarem parte dele; quanto ao desafio e às possibilidades, se referem à necessidade de que o grau de dificuldade da atividade seja compatível com a capacidade daqueles que se dispõem em realizá-la, sem, entretanto, que seja fácil demais. Em relação à dimensão simbólica, Macedo, Petty e Passos (2005, p. 20) a qualificam como "motivada e histórica" "motivada" porque faz sentido ao jogador e "histórica" porque localizada no tempo e espaço social e cultural daquele que joga. À expressão construtiva, os autores atribuem à qualidade da "errância", isto é, de "[...] uma construção que supõe ao mesmo tempo a consideração do conjunto de relações ou pontos de vista que a constituem, mesmo que minimamente, e uma referência ou direção.” (MACEDO; PETTY; PASSOS, 2005, p. 22).

\subsection{Jogo e Educação}

Ao longo da história, diversas foram as formas de compreensão do jogo enquanto recurso para a instrução de jovens e crianças. Seu uso já aparece documentado em textos de Platão e 
Aristóteles, mas foi com Frobel, no século XIX, “[...] que o jogo, entendido como objeto e ação de brincar, caracterizado pela liberdade e espontaneidade, passa a fazer parte da história da educação infantil." (KISHIMOTO, 1994, p. 16).

Atualmente, a principal questão sobre o uso do jogo na Educação está em seu caráter dúbio, proporcionado pela presença da "função lúdica - o jogo propicia a diversão, o prazer e até o desprazer quando escolhido voluntariamente," (KISHIMOTO, 1994, p. 19) concomitantemente com a sua "função educativa - o jogo ensina qualquer coisa que complete o indivíduo em seu saber, seus conhecimentos e sua apreensão do mundo." (CAMPAGNE, $1989^{20}$ apud KISHIMOTO, 1994, p. 19).

Segundo Kishimoto (1994, p. 19), esse "paradoxo do jogo educativo" - como o denominam “[...] alguns filósofos e teóricos, quando tratam da utilização do jogo pela educação [...]" leva autores como Brougère (1995, p. 208) a afirmar que não há, rigorosamente, jogo na escola. Isto porque, partindo das considerações de teóricos como Huizinga e Callois, Brougère $(1995,191)$ propõe que é a decisão de jogar que diferencia o jogo do não-jogo: "se um jogador de xadrez não é livre para decidir a sua próxima jogada, não é mais ele quem joga". Na medida em que não há possibilidade real de decisão, quer seja para iniciá-lo, quer seja para levá-lo adiante, o jogo na escola não pode ser considerado "jogo", porque o aluno, quando muito, pode escolher se quer jogar ou não, mas não pode escolher o que jogar.

Brougère (1995, p. 193) observa também que, como o jogo não tem finalidade para além do próprio prazer por ele proporcionado, o processo sempre é mais importante do que o resultado. No contexto didático, porém, seu interesse recai no aprendizado advindo do jogar e, portanto, no seu resultado.

Outro fator importante que contrapõe o jogo e sua utilização em contextos educacionais é a questão da incerteza, pois "sua indeterminação é seu interesse e, ao mesmo tempo, seu limite" (BROUGÈRE, 1995, p. 194). Na escola, o tempo é limitado e a aprendizagem deve ser garantida - portanto, o lugar da incerteza deve sempre ser minimizado.

\footnotetext{
${ }^{20}$ CAMPAGNE, F. Le jouet, l'enfant, l'eéducateur - roles de l'objet dans le développement de l'enfant et le travail pédagogique. Paris: Privat, 1989.
} 
Se, por um lado, em termos filosóficos, a idéia de jogo educativo permanece um paradoxo irreconciliável, por outro, a prática de sala de aula tem provado a sua pertinência enquanto estratégia de ensino (KISHIMOTO, 1992, p. 30): “[...] cresce o número de autores que adotam o jogo na escola em seu significado usual incorporando a função lúdica e a educativa." De natureza mais empírica do que teórica, os argumentos apresentados em favor ao uso do jogo na educação poderiam ser resumidos em (BROUGÈRE, 1999, p. 136):

- uma melhora substancial na motivação dos alunos, dado seu envolvimento e agência no contexto de sala de aula;

- a necessidade de se propor outros métodos além daqueles usados no sistema tradicional, um argumento defendido especialmente por aqueles que trabalham com dificuldades de aprendizagem entre jovens;

- a valorização da comunicação e da interatividade entre os alunos, ocasionando o surgimento de um espírito de grupo;

- o jogo enquanto recurso capaz de trazer para a sala de aula a complexidade de situações reais (por meio de simulações);

- o jogo como dimensão concreta, auxiliar na compreensão de conceitos abstratos;

- a necessidade do jogador em resolver problemas, agir, decidir e ser criativo. ${ }^{21}$

O jogo também tem sido objeto de estudo da psicologia. Para Piaget (1990, p. 117), dentro de uma perspectiva estruturalista e genética ${ }^{22}$, “[...] o jogo é essencialmente assimilação, ou assimilação predominando sobre a acomodação."

Kishimoto (2001, p. 32) resume a função do jogo na teoria de Piaget como:

21، If we take a look at the justifications most often given, they usually refer more to practical instruction than what we could call pedagogical pragmatics (Guide Edilude, 1995):

- $\quad$ Some concern motivation and the necessity to propose other methods than those used in the school system, an argument put forth most particularly in cases of reintegration of young adults with scholastic difficulties.

- Others concern communication and interactivity between trainees, between trainees and trainers, whether gaming/simulation should be used to construct the group or to put the accent on communication as such. It can also be away of valorizing team spirit.

- Gaming/simulation is presented as being able to translate the complexity of situations by highlighting the interdependence of factors and actions.

- Gaming/simulation is also evoked for its concrete dimension, the construction of an experience in which general and abstract knowledge may be put into play.

- We can also put the emphasis on the necessity for the player to solve problems, act, decide, and be creative. Contrary to the preschool sector, here practice and its demands precede theory" (tradução nossa).

${ }^{22 ، " E s t r u t u r a l i s t a, ~ p o r q u e, ~ d i f e r e n t e ~ d o ~ m o d o ~ u s u a l ~ d e ~ c l a s s i f i c a c ̧ a ̃ o ~ d o s ~ j o g o s ~(p o r ~ s e u ~ c o n t e u ́ d o, ~ m a t e r i a i s, ~}$ objetivos etc., ou por sua diversidade cultural), Piaget propõe quatro formas de organização dos jogos e os aspectos importantes de cada uma delas. Genética, porque o que estrutura as características expressa estágios de desenvolvimento do jogo nas crianças, culminando com o modo pelo qual ele será predominantemente nos adultos (lúdico, simbólico, regrado e construtivo)." (MACEDO, 2006, p. 20) 
Entendida como ação assimiladora, a brincadeira aparece como forma de expressão da conduta, dotada de características metafóricas como espontânea, prazerosa, semelhantes às do Romantismo e da biologia. Ao colocar a brincadeira dentro do conteúdo da inteligência e não na estrutura cognitiva, Piaget distingue a construção de estruturas mentais da aquisição de conhecimentos. A brincadeira, enquanto processo assimilativo, participa do conteúdo da inteligência, à semelhança da aprendizagem.

No âmbito da teoria de desenvolvimento da criança em estágios de Piaget há quatro grandes categorias de jogos: lúdico, simbólico, regrado e construtivo. Macedo (2006, p. 21) explica que no jogo lúdico, ou de exercício, "a criança poder repetir os esquemas de ação em constituição (levantar, pegar, olhar, bater, montar e desmontar, esconder e descobrir etc.) pelo próprio prazer de poder sempre fazer de novo." Os jogos de símbolos são constituídos pelas brincadeiras de faz-de-conta, histórias ou desenhos infantis "em que o real, enquanto conteúdo, subordina-se à dimensão imaginária ou simbólica de seus construtores." (MACEDO, 2006, p. 22), Já, no jogo regrado, “[...] o símbolo de assimilação individual cede [...] o passo quer a regra coletiva, quer ao símbolo representativo ou objetivo, quer aos dois reunidos," enquanto o jogo de construção caracteriza-se pelo "[...] desafio aceito ou autoimposto pelo jogador [...] de construir algo na direção do que foi planejado ou querido." (MACEDO, 2006, p. 24).

Ao concluir, Macedo (2006, p. 20) ressalta que em todos esses estágios, há sempre a manutenção de "o que define a anterior como parte fundamental da seguinte."

Para Vygotsky (2003), o jogo é fundamental para a aprendizagem, porque, por meio do brinquedo, a criança atinge a definição funcional de conceitos ou de objetos, atuando na Zona de Desenvolvimento Proximal (ZDP) ${ }^{23}$. Isso significa que, quando brinca, a criança mobiliza saberes para além daqueles que já domina, ampliando suas possibilidades de atuação no mundo real. $\mathrm{O}$ autor considera ainda que tanto a brincadeira de criança quanto o jogo regrado fazem parte de um continuиm. A regra, como principal característica de ambas as atividades, aparece na brincadeira infantil de forma implícita e não sujeita ao controle externo, enquanto

${ }^{23}$ Conceito criado por Vygotsky (2003) que define a distância entre o nível de desenvolvimento real, determinado pela capacidade de resolver um problema sem ajuda, e o nível de desenvolvimento potencial, determinado por meio de resolução de um problema sob a orientação de um adulto ou em colaboração com outro companheiro. 
em jogos como o xadrez, por exemplo, a regra é explícita e coletiva (VYGOTSKY, 2003, p. 131).

Segundo Kishimoto (1998, 141), Bruner avança nas idéias de Vygotsky sobre a importância do contexto social e histórico na aprendizagem e "aponta a potencialidade da brincadeira para a descoberta das regras e aquisição da linguagem.” Assim, para Bruner (1969, p. 155)

O brincar é antes de tudo uma atitude com a qual a criança aprende que as consequiências dos seus atos não são tão extremas quanto esperava ou temia - e significa, assim, aprender a limitar os resultados antecipados da atividade.

Ainda que todas as principais teorias psicológicas sobre a aprendizagem tratem da utilização de jogos como recursos facilitadores no ensino voltado à criança, algumas considerações importantes sobre a teoria desses autores apontam para a questão do uso de jogos para além da idade infantil. Brougère (1999, p. 141), em um artigo sobre a relação do jogo infantil e do adulto, comenta a respeito da teoria de Piaget:

Piaget (1951) é uma referência essencial por sua análise do desenvolvimento da inteligência que permite a classificação dos jogos em sensório-motor, jogos simbólicos ou jogos com regras. Devemos a ele também a análise fundamental da progressão do relacionamento da criança com as regras (Piaget, 1965). [...] As formas que os jogos se manifestam são, portanto, intimamente relacionadas às habilidades de mobilidade. Por isso, os jogos não podem ser idênticos para todas as idades (Corbeil, 1999; Millians, 1999; Wheatley, 1999). Começando em uma determinada idade durante a adolescência, as atividades das crianças orientadas para jogos com regras começam a assemelhar-se àquelas dos adultos, ou novas formas de jogos são postos no lugar (esportes, jogos em lan houses, videogames), que continuarão a ser praticados pelo adulto que o adolescente está se tornando. Testemunhamos o domínio do jogo e o aparecimento de novas formas de simulação que substituem o jogo da criança pequena. As características permanecem as mesmas, mas são expressas em formas e conteúdos diferentes ${ }^{24}$. [grifos nosso]

\footnotetext{
24“"Piaget (1951) is an essential reference through his analyses of the development of intelligence that enables the classification of games according to whether they are sensorial motor, symbolic games or games with rules. We also owe him for a fundamental analysis of the progression of the child's relationship to rules (Piaget, 1965). Other authors as well have and continue to contribute to this knowledge of children's capacities. The forms that games take are therefore closely linked to mobility skills. For this, games cannot be identical for all ages (Corbeil, 1999; Millians, 1999 [this issue]; Wheatley, 1999). Starting at a certain age during adolescence, children's activities oriented toward games with rules begin to resemble those of adults, or rather new forms of play activity are put into place (sports, parlor games, video games) that will continue to be practiced by the adult the adolescent is becoming. We witness the domination of the game and the apparition of new forms of simulation that replace the pretend play of the young child. The characteristics remain the same but are expressed in different forms and content". (tradução nossa).
} 
Similarmente, Macedo, Petty e Passos (2005, p. 14), pesquisadores dos processos de aprendizagem por meio do lúdico orientados pela teoria piagetiana, compreendem que:

[...] para adolescentes, adultos e idosos, o brincar continua com a mesma função. Para nós, o brincar é a saudade ou a recuperação daquela criança que fomos um dia, que dava sua vida para as coisas pelo gosto e pelo valor que tinham em si mesmas, pelos benefícios ou pelas consequiências inerentes ao próprio ato de sua realização.

Se, por um lado, reconhece-se a especificidade dos processos de aprendizagem da criança e do adolescente, por outro, entende-se que ambos integram um todo, que é o indivíduo, pois "[...] adultos foram um dia crianças e, assim sendo, jogaram jogos de crianças e experimentaram a evolução da brincadeira que todas as crianças experimentam." 25 (BROUGÈRE, 1999, p. 137).

Com relação à teoria de Vygotsky, os usos que os estudos sobre o ensino de língua estrangeira e de segunda língua fizeram acerca do autor tornaram o conceito de ZDP central para o TBLT, Task-based language teaching. Para Ellis (2003, p. 179):

A aprendizagem no TBLT ocorre por meio de atividades estruturadas de tal forma que apresentem um desafio compatível com as condições do aprendiz, mas que requeiram dele a execução de funções e usos de linguagem que habilitem a construção dinâmica de ZDPs ${ }^{26}$.

Como o ensino de língua estrangeira em cursos de idiomas não se resume apenas às crianças, estendendo-se a jovens e adultos também, isso implica um uso que extrapola os limites da educação infantil.

Bruner (1973, p. 37) também parece compreender similaridades na educação de crianças e de jovens:

A experiência tem demonstrado ser compensador o esforço para oferecer, à criança em crescimento, problemas que a estimulem a passar aos estágios seguintes de desenvolvimento. Assim observou David Page, um dos

\footnotetext{
${ }^{25}$ "This first theme prompts us to evoke a continuity: Adults were once children and therefore played children's games and experienced the evolution of play that children experience”. (tradução nossa).

${ }^{26}$ "The implication for effective task-based learning is that tasks must be structures in such a way that pose an appropriate challenge by requiring learners to perform functions and use language that enable them to dynamically construct ZPDs”. (tradução nossa).
} 
professores mais experiente de matemática elementar: 'ensinando desde o jardim da infância até o pós-graduado surpreendi-me com a semelhança intelectual dos seres humanos em todas as idades, [...].

Para o mesmo autor (BRUNER, $1977^{27}$ apud MOYLES, 2002, p. 24):

Pois a principal característica do brincar - quer infantil quer adulto - não é o seu conteúdo, e sim o seu modo. O brincar é uma abordagem à ação, não uma forma de atividade. [grifo nosso].

Portanto, o uso do lúdico enquanto recurso de ensino para adolescentes não se trata de uma redução das especificidades cognitivas dessa idade a uma aprendizagem infantilizada, mas sim, da busca pela motivação desses alunos por meio da agência e da socialização, características tão importantes para os indivíduos nesse estágio de desenvolvimento.

\subsection{O lúdico e o ensino e aprendizagem de Língua Estrangeira}

Da mesma forma em que há uma enorme variedade de métodos, abordagens e opções (e opiniões) sobre como deve, ou não, ser a aula de Língua Estrangeira, muitos são também os entendimentos sobre o uso de atividades lúdicas nessa área de ensino. Se, por um lado, a diversidade de objetivos permeia o discurso dos diversos métodos, por outro, a contradição entre as propostas de uso não invalida suas proposições, já que cada metodologia busca a melhor maneira de integrá-las às demais atividades de sala de aula, consoante com seus procedimentos próprios.

Diante dessa diversidade, não é de se estranhar que a compreensão sobre o que se chama de “jogo” também não seja unânime. Três denominações, porém, são mais comuns: simulações, role-play e jogo ${ }^{28}$. Cada uma implica características específicas e, portanto, necessitam de uma breve conceituação para além daquela já realizada no início deste capítulo, ainda que, nos materiais de apoio didático voltados para professores, a denominação geral "jogo" prevaleça sobre as demais (CROOKALL; OXFORD, 1990, p. 18).

\footnotetext{
${ }^{27}$ BRUNER, J.S. Introduction. In: TIZARD, B. e HARVEY, D. (org), The biology of play. Londres: Spastics international Medical Publications.

${ }^{28}$ Em inglês: "simulation" ou "simulation/gaming", "role play" e "game”.
} 
Para Crookall e Oxford (1990, p. 14), as simulações são entendidas como “[...] representações que, de alguma forma, se assemelham ao mundo real; são símbolos com referentes e, portanto, derivam seu sentido desses referenciais ${ }^{29}$." São "motivadas" porque guardam seu sentido na realidade de seus participantes, e "contextualizadas" por não se restringirem à prática de estruturas de linguagem. Portanto, as simulações dependem de que aqueles que estão nela envolvidos ajam de forma tal que se pretenda serem reais seus objetivos, mesmo todos sabendo que nenhuma conseqüência advinda de suas ações durante aquele momento terá efeito após o seu término. Por isso, as “[...] simulações encorajam os alunos a utilizarem os conhecimentos da língua recém aprendida de maneiras como a maioria das pessoas em outras situações (similares, mas reais) faz." ${ }^{30}$ (CROOKALL; OXFORD, 1990, p. 15).

Consequientemente, os "atores" da simulação não somente aprendem a utilizar seus conhecimentos lingüísticos, mas também têm a possibilidade de refletir sobre questões relativas à própria realidade em que vivem (CROOKALL; OXFORD, 1990, p. 15). Dessa forma, ao distanciarem-se dos pontos de vista comumente aceitos como verdadeiros na vida cotidiana por meio da interpretação de papéis (que podem ou não já terem sido desempenhados na realidade), esses alunos têm a oportunidade de experimentar perspectivas que, sem o uso da imaginação, não seriam possíveis na vida real.

O role-play, ainda que mais popular do que "simulação" entre professores de Língua Inglesa, é um termo que denomina apenas um tipo de simulação - aquela em que a "participação de cada um se caracteriza pela função social ou pela atividade exercida pelos personagens representados $^{31} . "($ CROOKALL; OXFORD, 1990, p. 19). Mais estereotipado, o role-play também é geralmente acompanhado por encenação teatralizada.

Já o termo “jogo”, segundo Crookall e Oxford (1990, p. 18), “[...] em ensino de língua estrangeira, refere-se a atividades ligeiras (charadas, jogo das 20 questões etc.), nas quais o

\footnotetext{
29 “[...] simulation is seen as somehow representing some real-worldly system; simulation is a symbol with a referent and thereby draws its essential meaning from that referent”. (tradução nossa)

30 "Simulations thus encourage language participants to use their new language in the ways most people do in other (similar, but real) situations." (tradução nossa)

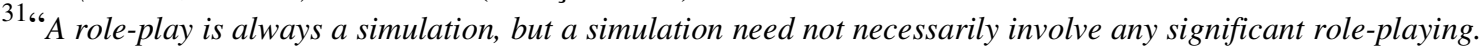
Role-play is usually defined as a social or human activity in which participants take on and act out specified roles, often within a predefined social framework or situation blueprint (a scenario)." (tradução nossa)
} 
principal objetivo é permitir aos jogadores a prática de elementos lingüísticos $[\ldots]^{32 \%}$. Porém, autores como Penny Ur (2001), Wright, Betterridge e Buckby (1993), Rivonlucri (2004), Langran e Purcell (1994), Rixon (1985), Richards e Rodgers (2001) e Larsen-Freeman (1986) adotam a palavra "jogo" indistintamente para simulação, role-play e jogo (no sentido referido anteriormente).

Neste trabalho, optou-se por se utilizar o termo "jogo", conforme esses autores sugerem, tanto por uma questão de freqüência quanto pela consistência de seu uso na literatura de diversas áreas do conhecimento.

Outra questão importante sobre o uso de jogos no ensino de Língua Estrangeira é a realização de procedimentos chamados de briefing e debriefing, especialmente no contexto da Abordagem Comunicativa.

O briefing é o momento em que são realizados os preparativos, em sala de aula, para que o jogo aconteça. Tanto aspectos formais da língua quanto relativos ao conteúdo necessário para a execução da atividade (jogo) subseqüente devem ser retomados nessa etapa. Portanto, no briefing, é importante que se garanta que todos saibam minimamente como poderão se expressar durante o jogo, assim como o que é necessário fazer para que se conclua a atividade (BULLARD, 1990, p. 57).

No decorrer do briefing, o professor também acessa o conhecimento prévio do aluno por meio de questões abertas que introduzem o assunto ou a estrutura (ou ambos) que serão abordados no jogo. Esse diagnóstico tem duas funções: (1) orientar o trabalho imediato do professor no sentido de antecipar dificuldades que possam impedir o bom andamento do jogo e (2) indicar necessidades específicas que terão de ser trabalhadas em momentos posteriores.

Já o debriefing, que ocorre logo após a realização da atividade lúdica, é um momento de reflexão sobre o que foi feito, tanto em termos lingüísticos quanto com relação ao conteúdo,

\footnotetext{
32 "[...] in language instruction, the term "game" usually refers to small-scale activities (e.g., CHARADES or 20 QUESTIONS), which aim principally at allowing players to practice a language component or a narrow range of them (e.g., structures, asking questions)”. (tradução nossa)
} 
sendo a ênfase maior em um ou outro, dependendo das características do próprio jogo (BULLARD, 1990, p. 58). Segundo Brougère (1999, p. 142), trata-se da:

[...] contribuição mais interessante à reflexão sobre jogos na educação para adultos, [...]. O debriefing é um tema familiar aos leitores deste jornal [dedicado ao uso de atividades lúdicas no ensino de língua estrangeira], portanto, não é necessário explicá-lo aqui, mas é inexistente quando se trata de educação de crianças pequenas. A importância atribuída nesses estudos a essa fase, ainda que seu tempo de realização em sala de aula seja curto, revela que, ao menos no contexto educação formal, o jogo não pode ser desenvolvido com o propósito de prover totalmente a aprendizagem. [...] O ponto crítico é realmente a reflexão que possibilita a passagem do divertimento à aprendizagem; portanto, a importância do debriefing, que aparece como contribuição essencial à pesquisa sobre jogos na educação. ${ }^{33}$

No ensino de Língua Estrangeira, entretanto, cada método possui uma forma específica de fazer uso das atividades lúdicas. Tanto no Método de Gramática e Tradução quanto no Método de Leitura, as atividades lúdicas não estão previstas entre as técnicas empregadas, pois preconizam a taxionomia do idioma ao seu uso de fato. Quando muito, aparecem em atividades descontextualizadas, com caráter de recompensa ou de preenchimento de tempo em que não é possível ser ocupado por outra atividade "séria" (WRIGHT; BETTERIDGE; BUCKBY, 1993, p. I; RINVOLUCRI, 2004, p. 3).

No Método Audiolingual, vários jogos tomam parte dos procedimentos habituais. O principal objetivo de sua utilização é a prática dos chamados disguised drills, isto é, a repetição, com pouca ou nenhuma variação, em coro ou individualmente, de sentenças contendo padrões gramaticais (LARSEN-FREEMAN, 1986, p. 47). O caráter lúdico advém mais da forma como tal exercitação é realizada do que propriamente da elaboração de uma situação de jogo. São utilizados recursos como a variação da entonação da voz, atribuindo à repetição um efeito jocoso; a repetição de frases ou palavras com a adição de novas palavras até o limite da memória; ou mesmo, repetições mais sofisticadas que se valem de cartas, como se fossem baralho, para o exercício da transformação do tempo verbal.

\footnotetext{
33، The most interesting contribution to reflection on gaming in adult education is the accent put on what follows the game stricto-senso, the after-game, that we usually call debriefing. Debriefing is a theme familiar to readers of this journal, so it is not necessary to develop it here, but it is particularly nonexistent when it comes to the young child. The importance given to this phase, even if it is sometimes short in terms of time, reveals that, at least within the context of formal education, the game cannot be designed to directly provide learning. A moment of reflexivity is required to make transfer and learning possible.[...] The critical point is indeed that reflection enables the passage from play to learning; therefore, the importance of the debriefing that appears as an essential contribution to research on play and gaming in education." (tradução nossa).
} 
Outra finalidade das atividades lúdicas nesse método é a de motivar a participação dos alunos na aula (RICHARDS, RODGERS, 2001, p. 27), o que deixa entrever duas questões importantes:

(1) Que a repetição como meio de fixação de frases e palavras causa cansaço e monotonia, levando ao desinteresse do aluno.

(2) Que a utilização de jogos, no ensino, de línguas é capaz de mobilizar alunos que já estão dispersos.

Richards e Rodgers (2001, p. 27) afirmam ainda que "[...] na Abordagem Comunicativa, os mesmos jogos [que os do Método Audiolingual] podem ser adotados para introduzir e/ou

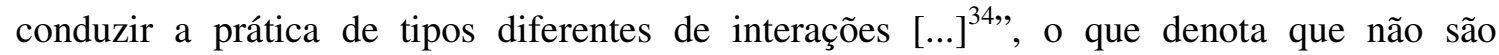
necessariamente as atividades lúdicas que mudam nessa outra concepção de ensino, mas seus objetivos.

Ainda que a criatividade do professor e a disponibilidade de recursos (e de informação) sejam fatores cruciais para a escolha das atividades em cada momento da lição, em uma sequiência típica de PPP (APRESENTAÇÃO, PRÁTICA E PRODUÇÃo ${ }^{35}$ ), a realização de alguns tipos de jogos é mais favorecida do que a de outros, pelas próprias exigências que o método impõe para cada etapa (RIXON, 1985, p. 69).

Assim, na APRESENTAÇÃO, quando o objetivo é prover um modelo de uso da linguagem a ser trabalhada nas demais etapas do processo, os jogos mais comuns são aqueles que oferecem um padrão de interação professor-classe, e a participação dos alunos se restringe a responder ou reagir dentro dos limites lingüísticos por eles já dominados. A produção dos novos elementos de linguagem, portanto, fica a encargo do próprio professor (RIXON, 1985, p. 70).

Durante a PRÁTICA, composta por exercitações dos itens recém apresentados, o padrão de interação entre os participantes dos jogos varia de momentos mais centrados no professor (professor - classe) para outros, mais autônomos (aluno - aluno). São privilegiadas atividades

\footnotetext{
34 "[...] in Communicative Language Teaching, the same games may be used to introduce or provide practice for particular types of interactive exchanges." (tradução nossa).

35 “Presentation, Practice e Production." (tradução nossa).
} 
lúdicas em que a repetição e a transformação das estruturas são realizadas pelos próprios alunos (RIXON, 1985, p. 70). Nessa etapa, os jogos são muito semelhantes àqueles concebidos no Método Audiolingual.

Na etapa final, a da PRODUÇÃO, espera-se que o aluno consiga não apenas produzir o item de linguagem, mas interagir por meio dele com seus colegas. Atividades como simulações são comuns nesse ponto da lição (RIXON, 1985, p. 70). Nas versões da Abordagem Comunicativa em que o esquema de aula baseia-se nos 4P's (Produção LIVRE, ApresentaÇão, PrÁticA e ProduÇão) ${ }^{36}$, esse é o momento em que ocorre uma TAREFA ${ }^{37}$ (HORNER; McGINLEY, 1990, p. 34).

Diferentemente do esquema do PPP, no qual as atividades lúdicas estão intrinsecamente relacionadas à estrutura da língua, no Task-based Language Teaching (TBLT), o foco central de todas as atividades é a TAREFA, cujas definições encontram-se no capítulo 3.3. Por se tratar de uma atividade que não se limita à comunicação de idéias, mas requer a simulação de uma situação real, a TAREFA necessariamente é uma atividade lúdica. Portanto, o jogo desempenha função central no método TBLT, porque é a partir dele que o resto de toda a estrutura do método se desenvolve.

Antecede a TAREFA uma etapa de pré-TAREFA (pre-TASK), cujo propósito é muito semelhante ao do briefing - afinal, o TBLT pode ser considerado uma das diversas interpretações modernas da Abordagem Comunicativa (RICHARDS; RODGERS, 2001, p. 223). Nessa fase, “[...] é importante apresentar o que o aluno terá de fazer e qual será o tipo de resultado que dele se espera. ${ }^{38, "}$ (ELLIS, 2007, p 244).

No PÓS-TAREFA (POST-TASK), à semelhança do debriefing, os alunos e o professor também fazem uma reflexão sobre o que foi (ou não) a atividade. A diferença, porém, do PÓS-TAREFA é a forma como essa atividade é conduzida. No debriefing, o foco pode concentrar-se na forma ou no conteúdo, ou em ambos, dependendo do objetivo pedagógico do jogo (BULLARD, 1990, p. 60); no PÓS-TAREFA, há uma ordem a ser seguida. Primeiramente, reflete-se sobre a TAREFA, no sentido de se resgatar tanto "[...] como eles [os alunos]

\footnotetext{
${ }^{36}$ Free Production stage, Presentation, Practice, Performance (HORNER, McGINLEY, 1990, p 34)

${ }^{37}$ No sentido empregado por Nunan (1993), citado neste trabalho na seção 3.3 .

38 "[...] provide an advance organizer of what the student will be required to do and the nature of the outcome they will arrive at." (tradução nossa)
} 


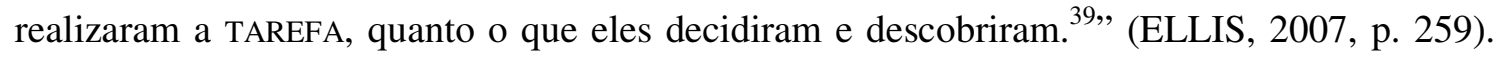
Depois, há uma discussão sobre questões relacionadas à forma, que passa pela revisão dos erros dos alunos e por atividades cujo objetivo é saná-los. Ao final, é comum que a TAREFA seja repetida, agora incorporando as correções sugeridas anteriormente (ELLIS, 2007, p. 258 261).

Se a maneira, o motivo e o momento da inserção dos jogos nos diversos métodos são muito distintos entre si, algumas observações procedimentais são comuns a todos os que recomendam o uso de jogos no ensino de língua estrangeira. Langran e Purcell (1994, p. 8) recomendam:

[...] definir a estrutura trabalhada e o vocabulário pertinente; escolher um tópico relevante; atentar para a viabilidade logística; certificar-se de que a sala de aula é adequada para a atividade; preparar a atividade com antecedência; promover oportunidades em que ocorra um trabalho acumulativo; certificar-se de que todos sabem as palavras essenciais; garantir que as instruções estão claras para todos; demonstrar, se necessário; contextualizar a situação; oportunizar a agência e a liberdade de escolha; durante a atividade, monitorar, auxiliar e mostrar-se disponível; finalizar o jogo no momento oportuno; apontar pontos que poderiam ter sido mais bem trabalhados logo após a atividade; deixar claro para os alunos qual o objetivo pedagógico do jogo; introduzir jogos desde os estágios iniciais. ${ }^{40}$

Muito semelhantes também são os argumentos daqueles em favor do uso do jogo no ensino de Língua Estrangeira. Entre seus principais defensores estão Wright, Betteridge, Buckby (1993), Rinvolucry (2004), Ur (2001), Langran e Purcell (1994), Crookall e Oxford (1990), Rixon (1985) que afirmam que os jogos mantêm o interesse na aula porque:

- na medida em que requerem a participação ativa do aluno em contextos reais de uso da língua, despertam o interesse em saber mais;

- as interações que ocorrem entre os alunos evolvidos em situação de jogo são verdadeiras. Por isso, o seu resultado ultrapassa a mera exercitação do conteúdo, pois envolvem troca de informações, opiniões, experiências e emoções;

\footnotetext{
39، [...] how they did the task and what they decided or discovered." (tradução nossa)

40 "Define the structure and vocabulary; choose a relevant topic; check the logistics; make sure the room is suitable; prepare the activity; look for opportunities for 'pyramid' work; check for the key words; make sure the instruction is clear; demonstrate, if necessary; set the scene; maximize ownership and choice; during the activity, monitor, prompt, be on hand; stop the game at the right time; look for effective follow-up; make sure learners understand why you have decided to use language games as a teaching strategy; introduce game early on in a beginner's class." (tradução nossa)
} 
- muitos jogos são adaptáveis a diversos contextos, níveis de ensino, arranjos de classes e objetivos pedagógicos;

- ao facilitarem o relaxamento, o aprendizado também é facilitado, pois o aluno fica menos ansioso diante das dificuldades enfrentadas para comunicar-se na língua-alvo;

- promovem um bom ambiente de relacionamento entre os alunos e o professor, o que influi no bom desempenho do aluno;

- oferecem chances para que alunos com habilidades diferentes possam praticá-las, sem privilegiar apenas aqueles que possuem maior facilidade em uma determinada habilidade;

- os alunos são levados a se arriscarem mais, já que nenhuma avaliação formal decorrerá desse tipo de atividade;

- o professor pode ficar livre para monitorar o andamento da atividade e prestar mais atenção nas necessidades específicas de cada aluno, sem perder o foco do todo. Por esse motivo, o professor é capaz de conhecer melhor seus alunos;

- a aprendizagem de uma língua é demorada e custosa, sendo que resultado desejado (ler, ouvir, escrever e falar com fluência e correção), muitas vezes, parece bastante distante. Os jogos funcionam como uma forma de prover um objetivo imediato para esse aprendizado: ganhar/perder/participar, o que pode ser visto como desafios reais em qualquer estágio do aprendizado.

O capítulo que se segue contextualiza o ensino e a aprendizagem de língua inglesa como Língua Estrangeira com o intuito de explicitar-se um modelo para a inserção da ludicidade na sala de aula de Língua Portuguesa. 
ENSINO DE LÍNGUA INGLESA COMO LÍNGUA ESTRANGEIRA: UM MODELO PARA O USO DO LÚDICO EM SALA DE AULA 


\title{
3. ENSINO DE LÍNGUA INGLESA COMO LÍNGUA ESTRANGEIRA: UM MODELO PARA O USO DO LÚDICO EM SALA DE AULA
}

\begin{abstract}
Diga-me, e eu esquecerei; ensina-me, e eu lembrarei; envolva-me, e eu aprenderei. ${ }^{41}$
\end{abstract}
Benjamin Franklin

A proposta de utilização de atividades lúdicas no ensino e aprendizagem de Língua Portuguesa no Fundamental II apresentada neste trabalho está baseada na experiência bem sucedida do uso desse recurso em aulas de Língua Inglesa como Língua Estrangeira por meio da Abordagem Comunicativa, em especial, do Task-based language teaching (TBLT), cujo aporte teórico encontra-se detalhado neste capítulo.

A escolha por esse modelo deve-se a três motivos: (1). Por se compreender que, salvo as devidas diferenças, o ensino de língua materna e o de língua estrangeira são ambos, em última análise, ensino de idiomas (JOVANOVIC, 1992). Portanto, o intercâmbio de estratégias pedagógicas entre ambas as disciplinas escolares (e áreas de estudo) só têm a contribuir na reflexão de alternativas viáveis para questões de interesse mútuo. (2) Ir ao encontro do que os principais lingüistas, pesquisadores e autores respeitados do meio acadêmico propõem enquanto mudanças necessárias para o ensino de Língua Portuguesa. (3) Tratar do uso consistente do jogo enquanto estratégia de ensino e aprendizagem, e não como expediente periférico pouco integrado às demais atividades de sala de aula.

A contextualização de algumas questões centrais no ensino de idiomas - a diferença entre os termos "método" e "abordagem" e a definição/ diferenciação entre língua materna, língua estrangeira e segunda língua - foi considerada importante, uma vez que situa as discussões sobre metodologia nessa área.

A opção pelo detalhamento do Método Gramática e Tradução, do Método de Leitura e do Método Audiolingual foi feita por razões distintas, mas igualmente relevantes para esta discussão. Os dois primeiros mereceram atenção graças a: (1) a permanência de muitos de

\footnotetext{
41“Tell me and I forget, teach me and I remember, involve me and I learn”. (tradução nossa).
} 
seus procedimentos e ideologias nas práticas ainda hoje observadas em aulas de Língua Inglesa, especialmente em escolas regulares; (2) as semelhanças entre algumas dessas práticas e o ensino de Língua Portuguesa tradicional. Quanto ao Método Audiolingual, sua referência se faz necessária pela integração de muitas das atividades lúdicas originalmente concebidas sob sua orientação nas práticas da Abordagem Comunicativa e do Task-based Language Teaching.

Um breve histórico sobre o ensino e aprendizagem de Língua Estrangeira no Brasil também pareceu convir, na medida em que contextualiza as especificidades locais com relação às maneiras como esses métodos e abordagens foram adotados no país.

\subsection{Conceitos}

Enquanto o termo "língua materna," também referido como L1, é bastante aceito nos meios acadêmicos para designar "a língua em uso no país de origem do falante e que o falante adquiriu desde a infância, durante o aprendizado da linguagem" (DUBOIS et alli, 1973, p. 378), a terminologia "língua estrangeira" não desfruta do mesmo privilégio (DELIBO, 1999, p.13). Há teóricos que entendem as denominações "L2" (segunda língua) e "língua estrangeira" como equivalentes (RIVERS, 1983) e outros, como Richards (1989, p.108-109), cujo entendimento é de que "língua estrangeira" trata-se de "[...] uma língua que é ensinada como matéria escolar, mas não é utilizada enquanto meio de instrução na escola nem como língua para comunicação no país (ex.: pelo governo, nos negócios ou na indústria)»42 enquanto o termo "segunda língua" deve ser aplicado a "[...] uma língua que não é a língua nativa no país, mas que é amplamente utilizada como um meio de comunicação (ex.: pela escola ou pelo governo) e que é geralmente falada ao lado de outra língua ou línguas. ${ }^{43}$

\footnotetext{
42 "[...] a language which is taught as a school subject but which is not used as a medium of instruction in school nor as a language of communication within a country (e.g. in government, business, or industry)." (tradução nossa).

43 "[...] a language which is not a native language in a country but which is widely used as a medium of communication (e.g. in education and government) and which is usually used alongside another language or languages." (tradução nossa)
} 
Por esse motivo, neste trabalho, a opção é pelo uso de "língua estrangeira", uma vez que no Brasil esse é o status da língua inglesa, cujo meio de circulação primordial é a escola, ainda que imprescindível, dada a globalização, nas relações comerciais com outros países.

Outra diferenciação importante é a entre "método" e "abordagem". Ainda que muitas vezes sejam utilizados indiscriminadamente, a maioria dos teóricos assume a distinção entre ambos os conceitos. De acordo com Nunan (2003, p. 333):

[...] abordagens são orientações filosóficas gerais sobre o que é a linguagem e o ensino" e "[...] método é um conjunto integrado de procedimentos de sala de aula, geralmente baseados em crenças sobre a natureza da linguagem e de seu ensino. Metodologia é o desenvolvimento de princípios e procedimentos de seleção, sequiênciação de tarefas e atividades de aprendizagem propositadas ${ }^{44}$. [grifos do autor].

Atualmente, porém, "[...] sob a influência de teorias lingüísticas e de teorias de aprendizagem recentes, mais do que métodos, fala-se em metodologia, termo mais abrangente, eis que, pelo seu sentido etimológico, pode implicar mais de um método [...]" (FERRO, 1998, p. 46), caracterizando aquilo que autores como Richards e Rodgers (2001) e Stern (1991) chamaram de a "Era Pós-método ${ }^{45 " . ~ A ~ d e c o r r e ̂ n c i a ~ m a i s ~ c l a r a ~ d e s s a ~ h i b r i d i z a c ̧ a ̃ o ~ d e ~ m e ́ t o d o s ~ e ́ ~ a ~ m a i o r ~}$ autonomia dos professores na escolha de procedimentos e de seqüênciações de conteúdo que atendam mais adequadamente as verdadeiras necessidades de seus alunos, resultando em um ensino mais personalizado (RICHARDS; RODGERS, 2001, p. 250). Por outro lado, facilitase a mau uso dessa flexibilidade, "[...] que pode ser confundida com abuso do direito de interpretar [...]" (DEMO, 2000 ${ }^{46}$ apud PLATERO, 2000, p. 28).

\subsection{Abordagens e Metodologias mais difundidas no Brasil}

Ministrado às classes mais abastadas desde os tempos do Império, o ensino e a aprendizagem do inglês popularizou-se no Brasil na mesma medida em que essa língua foi tomando o lugar

\footnotetext{
44"[...] approaches are general, philosophical orientations to language and teaching" $e$ "method is an integrated set of classroom procedures, usually based on beliefs on the nature of language and learning. Methodology is the development of principles and procedures for selecting, sequencing, and justifying learning tasks and activities." (tradução nossa)

${ }^{45}$ "Post-methods era" (tradução nossa).

${ }^{46}$ DEMO, P. A nova LDB - ranços e avanços. Campinas: Papirus Ed., 2000, p. 25.
} 
do francês nas relações internacionais, graças à crescente posição de hegemonia conquistada pelos Estados Unidos no contexto mundial. Já durante o Estado Novo "[...] a língua francesa, para o povo em geral, passou a ser sinônimo de 'elite', de refinamento de uma classe dominante $[\ldots]$ ", enquanto o inglês “[...] tornou-se sinônimo de modernidade [...]", pois “" $[. .$. os Estados Unidos representavam o modelo do futuro, não só em nível das grandes invenções e descobertas tecnológicas e científicas, mas também da realização pessoal, pelo modelo de Homem, sobretudo para os jovens brasileiros da classe média.” (BERGO E GOMES, 1985, p. 262).

Longe de se tratar de uma percepção relacionada a características intrínsecas aos idiomas, essa atribuição ideológica ao francês e ao inglês estava fortemente alicerçada na realidade social da população brasileira. Por um lado, apenas as classes mais abastadas tinham acesso à instrução, e, portanto, o pejo de "elitista" ao ensino do francês; por outro, a nossa crescente dominação política, econômica e cultural pelos norte-americanos. Em 1945, quando do início da "ajuda" técnica e financeira norte-americana ao Brasil, "[...] impôs-se ao nosso país a aquisição de parte expressiva de material norte-americano destinado à construção e equipamento de escolas de nível primário e médio, que foram instaladas com a ajuda dos Estados Unidos" (BERGO E GOMES, 1985, p. 266), inaugurando uma tendência que se consolidaria nos anos seguintes: o vínculo do ensino do inglês às exigências de qualificação técnica para o mercado de trabalho.

Se, a princípio, o inglês tomou parte do currículo escolar com a finalidade de franquear as portas do ensino superior aos membros da elite brasileira, (BERGO E GOMES, 1985, p. $247-$ 259), em uma tentativa de "ilustrar" a alta sociedade, a partir da II Guerra Mundial, seu ensino passou a ser gradativamente disseminado, tanto por escolas regulares quanto por institutos de idiomas $^{47}$, entre as classes mais populares. Em 1942, com a Reforma Capanema e a instituição do ensino ginasial, com quatro anos, e do colegial, com três anos de duração, houve um aumento de $20 \%$ na carga horária do ensino de Língua Estrangeira (RODRIGUES, 2005, p. 19). Segundo ainda a autora:

\footnotetext{
${ }^{47}$ Os institutos de idiomas começaram a se instalar no país nessa época.
} 
[...] a insistência na adoção do Método Direto $^{48}$ e o desdobramento dos objetivos de ensino em objetivos instrumentais, educativos e culturais presentes na Portaria Ministerial $\mathrm{n}^{0} 114$, de 29 de janeiro de 1943, intensificaram a cisão entre as recomendações oficiais e o cotidiano das escolas, pois 'o que se verificou nas salas de aula foi uma versão simplificada do Método de Leitura' (PLATERO, 2000, p. 20), no qual a oralidade restringia-se a leituras em voz alta de textos lexical e sintaticamente graduados.

Com a Lei de Diretrizes e Bases $n^{0}$ 4024, de 1961, iniciou-se um movimento de restrição da oferta do ensino de língua estrangeira em escolas regulares que, até então, ministravam, além do latim, "no curso ginasial, o francês e o inglês [...] obrigatórios, o primeiro, nas quatro séries e o segundo, só a partir da segunda série; no curso colegial (clássico ou científico), o francês e o inglês, nos dois primeiros anos e o espanhol, no primeiro ano" (FERRO, 1998, p. 34). A mudança de status de "obrigatória" para "complementar" ou "optativa" e a orientação para que só disponibilizassem cursos de línguas estrangeiras aqueles estabelecimentos que dispusessem de condições para realizá-los segundo as orientações do Método Direto representaram um "[...] retrocesso, uma vez que a lei acabou por impossibilitar uma política de ensino de línguas estrangeiras no Brasil, que se fazia emergir. Ao vincular a presença das línguas estrangeiras às condições do ensino, a lei teve, involuntariamente, um caráter reducionista e elitista." (FERRO, 1998, p. 35).

Em 1971, durante o regime Militar, por meio da lei $\mathrm{n}^{0}$ 5.692, a escola "[...] deixou de ser, sempre e necessariamente, um estabelecimento com endereço fixo e único, podendo funcionar em mais de um lugar, o que deu nascimento aos centros de línguas e possibilitou o recurso a outras instituições ou escolas especializadas, com validade de ensino regular e oficial." (FERRO, 1998, p. 36). Ainda que algumas instituições - na sua maioria, binacionais - já exercessem suas atividades no país, foi nessa época que ocorreu a proliferação desse tipo de estabelecimento de ensino, orientado, em sua grande maioria, pelo Método Audiolingual (FOGAÇA; GIMENEZ, 2007, p. 167).

Outra "novidade" foi a Resolução SE 163, de dezembro de 1985, da Secretaria da Educação de São Paulo, a qual:

\footnotetext{
${ }^{48}$ O Método Direto preconizava, em linhas muito gerais, o uso oral do idioma em sala de aula, sendo, por esse motivo, de difícil implantação, pois "os professores brasileiros não estavam capacitados para falar a língua estrangeira correta e fluentemente, [...]” (FERRO, 1998, p. 33).
} 
[...] transformou o ensino de L.E.M. (Língua Estrangeira Moderna), no $1^{\circ}$ grau, em atividade, cuja avaliação passou a não influir na promoção do aluno; para o $2^{\circ}$ grau, o ensino de L.E.M. continuou como disciplina, portanto, com nota. [...] Redundou, porém, numa perda ou diminuição da importância da matéria, trazendo, na prática, um desestímulo para os professores e um motivo de descaso para os alunos. (FERRO, 1998, p. 36).

Atualmente, a recomendação dos PCN de Língua Estrangeira no Ensino Fundamental (1998, p. 27) é a de que:

[...] na aprendizagem de línguas o que se tem a aprender é também, imediatamente, o uso do conhecimento, ou seja, o que se aprende e o seu uso devem vir juntos no processo de ensinar e aprender línguas. Assim, caracterizar o objeto de ensino significa caracterizar os conhecimentos e os usos que as pessoas fazem deles ao agirem na sociedade.

Pela reiteração da idéia de uso, processo e relação com a sociedade, o trecho acima citado dos PCN deixa entrever que a função primordial do ensino e aprendizagem de Língua Estrangeira deva ser a interação entre pessoas. Porém, nos mesmos PCN (1998, p. 20), encontra-se uma outra visão a respeito do objetivo do ensino dessa disciplina, causando ambigüidade quanto às suas finalidades. No capítulo reservado à introdução, lê-se:

[...] considerar o desenvolvimento de habilidades orais como central no ensino de Língua Estrangeira no Brasil não leva em conta o critério de relevância social para a sua aprendizagem. [...] o uso de uma língua estrangeira parece estar, em geral, mais vinculado à leitura de literatura técnica ou de lazer. Note-se também que os únicos exames formais em Língua Estrangeira (vestibular e admissão a cursos de pós-graduação) requerem o domínio da habilidade de leitura. [...] Além disso, a aprendizagem de leitura em Língua Estrangeira pode ajudar o desenvolvimento integral do letramento do aluno. A leitura tem função primordial na escola e aprender a ler em outra língua pode colaborar no desempenho do aluno como leitor em sua língua materna.

Tais características - o predomínio da habilidade da leitura, a aprendizagem condicionada à necessidade de uma qualificação formal/profissional e a identificação de seu aprendizado com o desenvolvimento intelectual do aluno - assemelham-se muito àqueles pressupostos advogados como princípios pelo Método de Gramática e Tradução e pelo Método de Leitura. Não por acaso, muitas das características próprias desses dois métodos ${ }^{49}$ são as mais

\footnotetext{
${ }^{49}$ Como a não obrigatoriedade do professor dominar corretamente o uso do idioma, conhecendo apenas a mecânica de sua estrutura, o trabalho com gramática (GRAMÁTICA 3) excessivo e descontextualizado, a leitura enquanto apenas suporte para exercícios de tradução/versão ou de compreensão de texto e a ênfase em aspectos lexicais e gramaticais, com prejuízo à comunicação e ao uso.
} 
comumente identificáveis nas práticas de sala de aula de Língua Inglesa nas escolas regulares do país. Como argumenta Leffa (1999, p. 24):

Esta ênfase na leitura tem gerado muitas críticas por parte de muitos professores. Argumenta-se que enquanto a própria lei baseia-se no princípio do pluralismo de idéias e de concepções pedagógicas (Art. $3^{\circ}$, Inciso III), os Parâmetros restringem o espaço de ação do professor. Embora haja muitos argumentos a favor dessa ênfase, a escola não vai recuperar o ensino da língua estrangeira, "deslocado para os cursos de línguas", como está explicitado nos próprios parâmetros, devido justamente à ênfase na leitura.

Quanto aos cursos de idiomas, livres das prescrições governamentais - ao menos no que diz respeito às dos $\mathrm{PCN}$, do $\mathrm{MEC}$, e às dos direitos adquiridos pelos profissionais da Educação, do Ministério do Trabalho - a Abordagem Comunicativa e os métodos dela decorrentes e, em menor escala, o Método Audiolingual, são inegavelmente preferidos ao Método de Gramática e Tradução.

Uma razão para isso pode ser encontrada em Richards e Rodgers (2001, p. 7), quando comentam sobre as causas do declínio do uso do Método de Gramática e Tradução : “[...] pouco a pouco, o sistema público de Educação parecia estar falhando com suas responsabilidades ${ }^{50,}$, pois tal método trazia consigo a falácia do ensino do falar sobre a língua e não da língua em si. Seu fracasso foi comprovado na Europa - do século XIX provocando a reforma do ensino de idiomas, o que levou à busca de alternativas que melhor contemplassem a necessidade por pessoas proficientes na compreensão do idioma, não somente em sua modalidade escrita, mas também, falada.

No Brasil, hoje, a disciplina de Língua Estrangeira integra o currículo dos alunos de escolas regulares por, no mínimo, 7 anos. Ainda assim, há uma crescente demanda por cursos paralelos, ministrados por escolas de idiomas. Certamente o que motiva essa população a freqüentar (e a pagar) por um serviço já oferecido pela escola regular é a insatisfação com os resultados obtidos nessa instituição (CARRIEL, 2002). Portanto, parece que a "relevância social" associada apenas ao domínio da leitura a que se referem os PCN não tem sido suficiente para cumprir de fato o papel social da escola: "[...] preparar o aluno para integrar a sociedade em que vive." (BRASIL, PCN - LÍNGUA ESTRANGEIRA - ENSINO FUNDAMENTAL, 1998, p. 27).

\footnotetext{
50“"...] increasingly, the public education system was seen to be failing in its responsibilities [...]." (tradução
} nossa) 
Vale lembrar, porém, de que boa parte da população não dispõe de condições financeiras para freqüentar tais cursos, tendo como única opção, aquele que, por direito, deveria oferecer-lhe um ensino que se bastasse, ou seja, que realmente tornasse o aluno proficiente em um idioma estrangeiro. A respeito da importância do currículo, Apple (1999, p. 22) afirma que:

[...] o currículo nunca é simplesmente a reunião neutra de conhecimentos, que de alguma forma surgem em textos e salas de aula de uma nação. Ele é sempre parte de uma tradição seletiva, a seleção de alguém, a visão de algum grupo do conhecimento legítimo. Ele é produzido a partir de conflitos culturais, políticos e econômicos, de tensões e compromissos que organizam e desorganizam as pessoas. A decisão de se definir o conhecimento de alguns grupos como mais legítimo, como o conhecimento oficial, enquanto o conhecimento de outros grupos mal é percebido, diz algo extremamente importante sobre quem tem o poder na sociedade.

Se a oferta de um ensino de língua estrangeira claramente limitado pelo seu próprio arcabouço teórico pode representar a desigualdade no acesso a melhores condições de vida, pode-se imaginar o que isso significa no domínio do ensino de língua materna, já que os pressupostos que sustentam o Método de Gramática e Tradução e o Método de Leitura não são muito diferentes do binômio gramática normativa/ exercícios de identificação e análise dos elementos constituintes da frase do ensino de Língua Portuguesa, promovido pela maioria das instituições de ensino do país.

Ainda que seja impossível resgatar todas as orientações metodológicas que influenciaram a prática do ensino e aprendizagem de inglês como Língua Estrangeira no Brasil, alguns métodos e abordagens tornaram-se notadamente mais populares do que outros. Em decorrência disso, muitas das atividades lúdicas que originalmente faziam parte de rotina de sala de aula de um determinado método acabaram sendo incorporados pelos professores a outros, de forma, muitas vezes, completamente alheia ao seu significado inicial. É por essa razão que se faz necessário o breve comentário sobre o Método de Gramática e Tradução, Método de Leitura e do Audiolingual.

Oriundo do ensino de línguas clássicas, o Método de Gramática e Tradução baseia-se no uso da língua materna como suporte de aprendizado, por meio da tradução, das estruturas e do vocabulário da língua estrangeira a ser aprendida. Seu objetivo é tornar o aluno capaz de ler e escrever no idioma estudado, além de desenvolver a disciplina mental e as faculdades 
intelectuais pelo exercício de seu aprendizado. O suporte didático consiste normalmente de textos e a frase é a unidade básica da aprendizagem. A correção é enfatizada e o erro, punido. A gramática é ensinada de forma expositiva. (RICHARDS; RODGERS, 2001, p. 5-6)

As principais técnicas relacionadas a esse método são: (1) a tradução de passagens literárias; (2) questões de compreensão de texto; (3) exercícios gramaticais - tais como a busca por antônimos ou sinônimos; (4) memorização de vocabulário e (5) redação sobre um dos temas do texto de leitura (LARSEN-FREEMAN, 1986, p.13-14).

Apesar da monotonia e a frustração experimentada pelos alunos que por ele passaram, "[...] para quem aprender uma língua estrangeira significava uma tediosa experiência de memorização de listas intermináveis de regras gramaticais e vocabulário inúteis, além de tentativas de traduções de passagens empoladas ou textos literários [...]" ${ }^{, 51}$ (RICHARDS; RODGERS, 2001, p. 6), o Método de Gramática e Tradução ainda persiste em muitas das práticas que norteiam as atividades mais corriqueiras das escolas públicas (e particulares) brasileiras (NOGUEIRA, 2007, 23), ao lado das do Método de Leitura simplificado.

A popularização nos Estados Unidos do Método de Leitura deveu-se principalmente às recomendações do relatório Coleman (1929), cuja conclusão era a de que, em média, a população americana estudava apenas dois anos de língua estrangeira e, em tão pouco tempo, seria impossível desenvolver as quatro habilidades, sendo a leitura a mais adequada a ser trabalhada nesse período. (RICHARDS; RODGERS, 2001, p. 50).

Assim como no Método de Gramática e Tradução, a leitura desempenha papel central em suas práticas de sala de aula. A diferença, porém, é a de que neste, os textos são adaptações cujo nível de dificuldade lexical e gramatical (GRAMÁTICA 3) é graduado, enquanto aquele se utiliza de textos originais (de preferência, clássicos da literatura). Outra semelhança é o uso da língua materna nas instruções (STERN, 1991, p. 461). São também suas características, de acordo com Stern (1991, p. 461):

A introdução do estudo da língua estrangeira era realizada oralmente, como no Método Direto, para facilitar a pronúncia e porque se acreditava que o

51 "[...] for whom foreign language learning meant a tedious experience of memorizing endless lists of unusable grammar rules and vocabulary and attempting to produce translations of stilted or literary prose[...]." (tradução nossa). 
'discurso interno' era um recurso facilitador da compreensão da leitura. Várias técnicas de leitura em língua materna foram adotadas. Acima de tudo, o controle do vocabulário era considerado de suma importância, assim como a distinção entre leitura intensiva, para um estudo detalhado, e leitura extensiva, feita rapidamente e com propósito de compreensão geral do texto. ${ }^{52}$

No Brasil, "[...] fala-se em uma versão simplificada, pois, originalmente, o método também incluía a oralidade sob a forma de leituras em voz alta, o que não era [aqui] aplicado." (PLATERO, 2000, p. 20).

O Método Audiolingual, por sua vez, vai completamente de encontro às premissas do Método de Gramática e Tradução e do Método de Leitura. Como relatam Richards e Rodgers (2001, p. 14-16), diante da necessidade da comunicação oral eficiente enfrentada pelos norteamericanos durante a Segunda Guerra Mundial, o exército desenvolveu um método cujo principal objetivo era o ensino e aprendizagem da língua falada de forma rápida e com pronúncia próxima da nativa.

Do aperfeiçoamento desse método e da aplicação dos conceitos da psicologia (de cunho behaviorista) e da lingüística (estruturalista) ao ensino de idiomas surgiu, no final da década de 50, o Método Audiolingual. Suas principais características são:

[...] (1) separação das habilidades - escuta, fala, leitura e escrita - e a primazia das habilidades audiolinguais sobre as gráficas; (2) uso de diálogos como principais meios de apresentação da língua; (3) ênfase em certos aspectos técnicos da prática; (4) uso de laboratório de idiomas; (5) o estabelecimento de uma teoria psicológica e lingüística como base para o método. ${ }^{53}$ (STERN, 1991, p. 462)

\footnotetext{
52 "The introduction of the second language was oral and in direct method because facility in pronunciation and in 'inner speech' was regarded as an important aid in reading comprehension. Several techniques were adopted from native language reading instruction. Above all, vocabulary control in reading texts was regarded as of prime importance, and so was the distinction between intensive reading for detailed study and extensive rapid reading of graded 'readers' for general comprehension."(tradução nossa).

53 “[...] (1) separation of the skills - listening, speaking, reading, and writing - and the primacy of the audiolingual over the graphic skills; (2) the use of dialogues as the chief means of presenting the language; (3) emphasis on certain practice techniques, mimicry, memorization and pattern drills; (4) the use of the language laboratory; (5) establishing a linguistic and psychological theory as a basis for the teaching method." (tradução nossa)
} 
Os exercícios de rotinização (pattern drills) estão entre as principais características dos procedimentos de sala de aula, além da repetição em coro e dos jogos para a prática de gramática (LARSEN-FREEMAN, 1986, p. 45-47).

A afirmação de Chomsky (1957 54 apud RICHARDS; RODGERS, 2001, p. 65) de que “[...] a língua não é apenas uma formação de hábito. É característica do comportamento lingüístico comum a inovação, formação de novas sentenças e padrões de acordo com regras intrincadas e de grande abstração [...]"55 não levou apenas ao declínio do Método Audiolingual, mas à busca por uma outra maneira de se ensinar idiomas que pudesse contemplar a criatividade característica da linguagem em uso. A solução mais bem sucedida foi a Abordagem Comunicativa, surgida no final da década de 70.

Apoiada por uma visão funcionalista da linguagem, o principal objetivo dessa corrente teórica encontrar meios para o desenvolvimento da competência comunicativa do aluno. Por competência comunicativa entende-se a capacidade de produzir enunciados apropriados ao contexto em que ocorre a fala, assim como o conhecimento de estruturas, significados e funções lingüísticas (RICHARDS; RODGERS, 2001, p 144). Segundo Widdowson (1990, p. 215, 216):

Se contrastarmos ambas as expressões [ensinar inglês como comunicação e ensinar inglês para comunicação], 'ensinar inglês como comunicação' parece focar a atenção na natureza do fenômeno a ser ensinado: sugere estar implicado, a meu ver, que o objetivo do professor é apresentar a língua de tal forma que sua qualidade comunicativa seja preservada. Parecemos dizer com isso que há aspectos da língua que são mais comunicativos e que são eles os que devem especialmente constituir conteúdo para o estudo. 'Ensinar para comunicação', por outro lado, parece modificar a ênfase do estudo da língua enquanto uso com vistas a uma finalidade comunicativa, e, com isso, trazer à cena a aprendizagem de objetivos, referindo-se não àquilo que está sendo ensinado em sala de aula, mas ao resultado desejável para a atividade. [...]. Portanto, se elas [as atividades] não forem conduzidas para comunicação na sala de aula, acabarão por se tornarem itens a serem armazenados na memória não muito diferentemente daqueles das rotinizações, apenas tendo sido rotuladas de outra forma. ${ }^{56}$

\footnotetext{
${ }^{54}$ CHOMSKY, N. Linguistic theory. In: ALLEN, J.P.; BUREN; P. van (org.). Chomsky. Selected Readings. London: Oxford University Press, 1966, p. 152 - 159.

55،[...] language is not a habit structure. Ordinary linguistic behaviour characteristically involves innovation, formation of new sentences and patterns in accordance with rules of great abstractness and intricacy." (tradução nossa)

56 "If one sets the two expressions into contrastive opposition, 'Teaching language as communication' seems to focus attention on the nature of the phenomenon to be taught: it seems to carry the implication, I think, that the teacher's aim should be to present language in such a way as to preserve its communicative character. It seems
} 
Isso significa que o ensino da gramática e do vocabulário é importante, mas o uso da língua deve ser preponderante à forma. Portanto, a finalidade do ensino e aprendizagem é a comunicação de significados.

Quer seja pela longevidade, quer seja pela abrangência, a definição de suas características mais representativas tornou-se um tanto difícil. Segundo Richards e Rodgers (2001, p. 172), seus elementos comuns e fundamentais são:

- os alunos aprendem a língua por meio do uso;

- as situações de comunicação autênticas e com significado relevante devem ser o objetivo das atividades de sala de aula;

- a fluência é uma dimensão importante da comunicação;

- a comunicação envolve a integração de diferentes habilidades lingüísticas;

- aprender é um processo de construção criativa e envolve tentativa e erro ${ }^{57}$.

Essas características fazem da Abordagem Comunicativa um marco difícil de ser contestado no âmbito do ensino de idiomas, embora não signifique a inexistência de problemas. $\mathrm{O}$ próprio fato de a teoria dar margem a diversos tipos de práticas, muitas vezes, inclusive, contraditórias, é um dos pontos muito criticados no meio acadêmico (DELIBO, 1999, p. 28).

Outra crítica comum é o fato de que tanto os métodos quanto as abordagens trazem consigo um esquematismo exagerado, isto é, há uma independência entre o está previsto para acontecer na aula e a real necessidade dos alunos. Se, por um lado, isso estabelece uma organização do conteúdo a ser trabalhado, criando uma previsibilidade, para o bem e para o mal, do que pode ocorrer na situação real de ensino, por outro, dificulta a atuação do

\footnotetext{
to suggest that there are aspects of language itself which are communicative and that these should constitute the essential content of courses. 'Teaching language for communication', however, seems to shift the emphasis from language as such to the activity of using it to achieve communicative ends, and to focus attention on learning objectives, referring not to what is actually being taught in the classroom but the desired outcome of that teaching activity. [...] For unless they are used for communication in the classroom they remain items to be stored as knowledge not essentially different from sentence patterns but with new labels attached." (tradução nossa).

57 "Learners learn a language through using it to communication; Authentic and meaningful communication should be the goal of classroom activities; Fluency is an important dimension of communication; Communication involves the integration of different language skills; Learning is a process of creative construction and involves trial and error." (tradução nossa)
} 
professor, que fica restrito ao que o método ou a abordagem (ou, na maioria das vezes, ao que o livro) prescreve (STERN, 1991, p. 204).

Nesse sentido, alguns autores como Richards e Rodgers (2001) e Stern (1991) afirmam que estamos hoje em um momento pós-método, no qual o professor deve se valer dos recursos disponíveis, independentemente das prescrições desta ou daquela orientação pedagógica. Não se trata, porém, de um vale-tudo, mas sim, de adaptar, tanto quanto necessário às necessidades dos alunos, as condições de ensino, na busca de melhores resultados.

Mesmo assim, é possível afirmar que a maioria das práticas promovidas em sala de aula hoje dentre as que consideram o desenvolvimento das quatro habilidades - estão, de alguma forma, impregnadas pelos conceitos que norteiam a Abordagem Comunicativa.

\subsection{Da Abordagem Comunicativa ao Task-based language teaching}

A evolução das pesquisas sobre aquisição e aprendizagem durante as décadas de 80 e 90 propiciou o surgimento de correntes de pensamento dentro da Abordagem Comunicativa que buscavam por mais oportunidades de situações nas quais a aquisição pudesse ocorrer do que aquelas previstas pelo procedimento metodológico típico da Communicative Languange Teaching (CLT, interpretação mais popular da Abordagem Comunicativa), o PPP ${ }^{58}$ (ELLIS, 2003, p. 27).

Paralelamente, a penetração das idéias de Vygotsky, via Teoria Sócio-cultural da Mente $(\mathrm{SCT})^{59}$, no ensino de língua estrangeira proporcionou a fundamentação teórica necessária

\footnotetext{
${ }^{58}$ Presentation, Practice, Production. Procedimento caracterizado pela apresentação da gramática, por meio de texto escrito ou oral, seguido pela sua prática (primeiramente controlada, depois menos controlada) e finalizado pela produção do item gramatical focalizado em um contexto situacional. (RICHARDS, RODGERS, 2001, p. 66).

${ }^{59}$ Sociocultural Theory of Mind. São características dessa teoria: (1) o entendimento de que a aprendizagem é sempre mediatizada, quer seja pela interação social, pelo self, via discurso intra-pessoal, ou por objetos (LANTOLF apud ELLIS, 2003, p. 176); (2) a compreensão, apoiada no conceito de ZDP de Vygotsky, de que o desenvolvimento de uma nova habilidade tem sempre uma dimensão social associada a uma psicológica (ELLIS, 2003, p. 179); (3) a importância do procedimento de scaffolding [traduzido por Kishimoto (2007, p. 260) como "andaime"], entendido como "o processo dialógico no qual um par mais hábil ajuda outro em uma tarefa que este
} 
para que uma nova concepção metodológica fosse proposta: o Task-based Langauge Teaching (ELLIS, 2003, cap. 6).

No centro desse método está a TAREFA (TASK). Várias são as suas definições, tendo-se optado aqui pelas duas mais comumente citadas:

[...] um elemento do trabalho escolar que envolve os alunos em compreender, manipular, produzir e interagir com a língua alvo enquanto sua atenção está focada principalmente no sentido e não na forma. A TAREFA também deve conter uma impressão de completude, sendo possível de existir enquanto ato comunicativo sem outro apoio ${ }^{60}$. (NUNAN, 1993, p. 7)

Uma TAREFA é um plano de trabalho que requer do aluno o processamento da linguagem de forma pragmática, com o objetivo de atingir um resultado que possa ser avaliado em termos de se o conteúdo foi veiculado de forma correta ou apropriada. Por isso, ela requer tanto que a atenção seja primeiramente voltada ao sentido quanto que sejam utilizados os próprios recursos lingüísticos do aluno, embora a elaboração da TAREFA possa predispô-lo a escolher algumas formas em particular de linguagem. Uma TAREFA pretende um resultado lingüístico que se assemelhe, direta ou indiretamente, a forma com que a linguagem é utilizada no mundo real. Igualmente a outras atividades lingüísticas, uma TAREFA pode exercitar conhecimentos produtivos ou passivos, habilidades escritas ou orais e vários outros processos cognitivos. ${ }^{61}$ (ELLIS, 2003, p. 16)

Os principais pontos em comum que ambos os autores atribuem à TAREFA - sua natureza escolar, a necessidade de um resultado para além do plano lingüístico, seu referencial no mundo real, a atenção focada no conteúdo e não na forma e o sentido de completude guardam grandes semelhanças àquelas já discutidas no capítulo anterior, em 2.3, com relação

ainda não é capaz de executar sozinho" (ELLIS, 2003, p. 181); (4) a aproximação do conceito de atividade de Leontiev (1999, p. 59-83) ao de tarefa (ELLIS, 2003, p. 183).

60 "....] a piece of classroom work which involves learners in comprehending, manipulating, producing and interacting in the target language while their attention is principally focused on meaning rather than form. The task should also have a sense of completeness, being able to stand alone as a communicative act in its own right." (tradução nossa).

61 "A TASK is a workplan that requires learners to process language pragmatically in order to achieve an outcome that can be evaluated in terms of whether the correct or appropriate propositional content has been conveyed. To this end, it requires them to give primary attention to meaning and to make use of their own linguistic resources, although the design of the task may predispose them to choose particular forms. A TASK is intended to result in language use that bears a resemblance, direct or indirect, to the way language is used in the real world. Like other language activities, a task can engage productive or receptive, and oral or written skills and also various cognitive processes." (tradução nossa). 
à simulação. Tanto que, para Breen (BREEN, $1987^{62}$ apud NUNAN, 1993, p. 6) "a TAREFA [...] varia [...] de um simples exercício, a uma atividade mais longa e complexa como uma situação problema, uma simulação ou uma tomada de decisão ${ }^{63}$."

Além disso, o uso da imaginação é imprescindível à transposição didática de situações reais para a sala de aula, dada a natureza e os objetivos distintos daquilo que é feito para uso escolar e daquilo que provém de seu uso social real. É, portanto, a imaginação o elemento que relaciona a TAREFA - confinada à escola - à realidade a que se pretende imitar. Essa característica da TAREFA a aproxima bastante daquela que é considerada por Vygotsky (2003, p. 123) o principal objetivo do jogo - a experimentação para além do limite daquilo que já é dominado, por meio da imaginação.

Similarmente à forma como um jogo é trabalhado na Abordagem Comunicativa, por meio dos recursos de briefing e debriefing ${ }^{64}$, a TAREFA, no TBLT, é introduzida por uma PRÉ- TAREFA (PRE-TASK) e finalizada por uma PÓS- TAREFA (POST-TASK). Duas são as forma de condução destas etapas, sendo que Willis (1996) e Nunan (2004) são os dois pesquisadores expoentes de cada uma. Para Willis (WILLIS, $1996^{65}$ apud ELLIS, 2003, p. 244), a seqüência de uma TAREFA deve conter:

\begin{tabular}{|c|c|}
\hline Fase & Procedimentos mais comuns \\
\hline PRÉ-TAREFA & $\begin{array}{l}\Rightarrow \text { Informações necessárias para a realização da TAREFA } \\
\Rightarrow \text { Planejamento de tempo } \\
\Rightarrow \text { Modelo da TAREFA }\end{array}$ \\
\hline Durante a TAREFA & $\begin{array}{l}\stackrel{\Rightarrow}{\Rightarrow} \text { Tempo determinado } \\
\Rightarrow \text { Número de participantes }\end{array}$ \\
\hline PÓS-TAREFA & $\begin{array}{l}\Rightarrow \text { Apresentação da TAREFA para o grupo } \\
\Rightarrow \text { Trabalho com conteúdo ou forma problemáticos } \\
\Rightarrow \text { Repetição da TAREFA }\end{array}$ \\
\hline
\end{tabular}

Tabela 3 - Sequiência do TBLT, segundo Willis (ELLIS, 2003, p. 244) ${ }^{66}$

\footnotetext{
${ }^{62}$ BREEN, M. Learner contributions to task design. In: CANDLIN MURPHY (eds.) Revised Syllabus Specifications for the Omani School English Language Curriculum. Muscat: Ministry of Education and Youth, 1987.

63،'TASK' is therefore assumed to refer to a range of workplans which have the overall purposes of facilitating language learning - from the simple and brief exercise type, to more complex and lengthy activities such as group problem-solving or simulations and decision-making." (tradução nossa).

${ }^{64}$ Apresentados e discutidos no capítulo anterior.

${ }^{65}$ WIILIS, J. A framework for Task-based Learning. Hallow: Longman, 1996.

${ }^{66}$ "A. PRE-TASK* Framing the activity (e.g. establishing the outcome of the TASK); * Planning time; * Doing a similar TASK. B. During TASK* Time pressure; * Number of participants. C. POST-TASK* Learner report * Consciousness-raising; * Repeat TASK.” (tradução nossa).
} 
Assim, na fase da PRÉ-TAREFA, é importante que "se prepare os alunos para a TAREFA de forma que se promova a aquisição da linguagem ${ }^{67 "}$ (ELLIS, 2003, p. 244). Para isso, a autora (ELLIS, 2003, p. 245) aponta para quatro procedimentos fundamentais: “(1) a realização, pelos próprios alunos, de uma atividade modelo, semelhante a que terão de fazer na fase posterior; (2) a apresentação de um modelo pelo professor; (3) a realização de uma atividade (não- TAREFA) que prepare os alunos para a TAREFA; (4) o planejamento estratégico de como a TAREFA será realizada. ${ }^{68}$,

Durante a realização da TAREFA, o professor monitora o trabalho dos alunos, auxiliando, quando necessário, a solucionar possíveis dúvidas. Decisões como: tipos de interação entre os alunos (se em grupos, em pares, etc.), tempo para a realização da TAREFA e acesso a materiais de consulta trazem resultados bastante distintos nas atividades realizadas nesse momento (ELLIS, 2003, p. 250).

O PÓS-TAREFA é o momento de apresentação dos resultados da TAREFA e a decorrente reflexão sobre o que foi (ou não) feito. Os objetivos pedagógicos dessa fase podem ser resumidos em: “(1) promover uma oportunidade para a repetição da TAREFA; (2) encorajar a reflexão dos alunos sobre a realização da TAREFA, e (3) encorajar a atenção à forma, em especial, àquelas que provaram ainda serem problemáticas para os alunos enquanto apresentavam suas TAREFAS. ${ }^{69,}$

Já, para Nunan (2004, p. 20), esse procedimento está dividido em seis momentos, como observado na tabela abaixo:

\footnotetext{
67 "The purpose of the PRE-TASK phase is to prepare students to perform the task in ways that will promote acquisition." (tradução nossa).

68 "These alternatives can be tackled procedurally in one of four ways; (1) supporting learners in performing a task similar to the task they will perform in the during-task phase of the lesson, (2) asking students to observe a model of how to perform the TASK, (3) engaging learners in non-task activities designed to prepare them to perform the TASK or (4) strategic planning of the main task performance. We will consider each in some detail”. (tradução nossa).

69 “(1) to provide an opportunity for a repeat performance of the TASK, (2) to encourage reflection on how the task was performed, and (3) to encourage attention to form, in particular to those forms that proved problematic to the learners when they performed the TASK." (tradução nossa).
} 


\begin{tabular}{|c|c|}
\hline Fase & Procedimentos mais comuns \\
\hline Ativação da schemata & $\Rightarrow$ Ativação do conhecimento de mundo do aluno \\
\hline Prática controlada contextualizada & $\Rightarrow$ Prática baseada no conhecimento de mundo do aluno \\
\hline $\begin{array}{l}\text { Trabalho com habilidades } \\
\text { "receptivas" }\end{array}$ & $\Rightarrow$ Apresentação do contexto situacional \\
\hline Foco na forma & 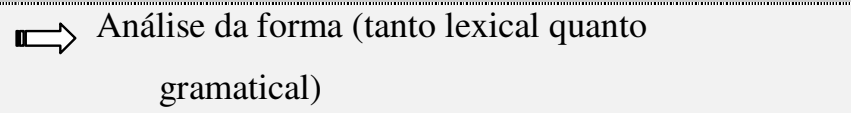 \\
\hline Prática menos controlada & $\Rightarrow$ Prática incorporada aos novos itens aprendidos \\
\hline TAREFA & $\longrightarrow$ Produção de língua em um contexto propositado \\
\hline
\end{tabular}

Tabela 4 - Sequiência do TBLT, segundo Nunan (2004, p. 20)

No modelo de Nunan (2004), a TAREFA não representa somente o fim da unidade de ensino (quer essa seja entendida como o capítulo do livro, a aula, ou o projeto do semestre), mas é o momento em que todo o trabalho realizado é integrado em uma única atividade. Disso decorrem duas observações: (1). Ainda que a TAREFA seja o objetivo final (e primeiro, porque tudo na unidade de ensino converge para a sua realização), ela não é central no modelo de Nunan, porque não gera os demais procedimentos, como no modelo de Willis, citado acima. (2) Como notado por Feeney (2006 $6^{71}$ apud OXFORD, 2006, p. 111), esse modelo aproximase muito da formatação do PPP, com a única diferença de acrescentar uma prática controlada a mais em seu procedimento.

No Brasil, o modelo de TBLT mais adotado é o de Nunan (2004). As aulas observadas durante o período de Entrada em Campo realizada para a pesquisa de cunho etnográfico deste trabalho orientavam-se por um modelo misto, com características desse tipo de TBLT (a realização da TAREFA FINAL como encerramento de uma Unidade de Trabalho) e da metodologia clássica do CTL (o foco na forma e não no conteúdo).

Ainda que, como Richards e Rodgers (2001) defendem, cada método tenha seu mérito e seu problema e, portanto, é melhor adaptar-se às necessidades reais de sala de aula do que atrelarse a um método fixo, o modelo de uso de TAREFAS proposto por Willis (WILLIS apud ELLIS, 2003, p. 244) vem ao encontro da proposta de ensino e aprendizagem que balizou a realização

\footnotetext{
70 “*schema building; *controlled practice embedded in a context (unlike traditional controlled practice), *authentic receptive skills work, *a focus on form (lexical and/or grammatical), *freer practice ("communicative activities"), and at last * the (communicative) task itself." (tradução nossa).

${ }^{71}$ Feeney, A. Review of Task-based language teaching (2004) by David Nunan. ELT Journal, 60 (2), 2006 . p. 199-201.
} 
deste trabalho, na medida em que seus pressupostos teóricos são muito próximos daqueles sugeridos pelo uso de Seqüências Didáticas (SCHNEUWLY \& DOLZ, 2007); (SEMEGHINISIQUEIRA, 1997, 2006c).

Assim, o conceito de TAREFA foi utilizado aqui como ponto de convergência entre práticas de ensino de Língua Portuguesa e de Língua Estrangeira, como forma de trazer o lúdico enquanto elemento central da organização de suas atividades. 
ENSINO DE LÍNGUA PORTUGUESA: PERSPECTIVAS E POSSIBILIDADES 


\section{ENSINO DE LÍNGUA PORTUGUESA: PERSPECTIVAS E POSSIBILIDADES}

No meio do caminho tinha uma pedra

tinha uma pedra no meio do caminho

Carlos Drummond de Andrade

Enquanto as demais disciplinas escolares parecem ter seus objetos de estudo razoavelmente delimitados pelos seus respectivos campos do saber $^{72}$, Língua Portuguesa - assim como todo ensino e aprendizagem de língua materna - parece ter dificuldades em estabelecer aquilo que lhe é próprio e peculiar.

Isso porque o desenvolvimento de habilidades de oralidade, leitura e escrita não são exclusivamente tarefa das aulas de Língua Portuguesa, mas perpassam os objetivos de todas as demais disciplinas escolares. Além disso, como língua materna, os alunos já chegam à escola sabendo muito sobre seu funcionamento - são falantes proficientes, ainda que, muitas vezes, de uma modalidade e/ou variedade distinta daquela que ali encontrará.

Por esse motivo, muitos acreditam que seja o objeto próprio do ensino e aprendizagem de Língua Portuguesa a gramática. Outros não. E outros, ainda, recontextualizam o que significa ensinar e aprender gramática.

Destarte, discutir o que deve ser ensinado em aulas de Português não parece ser sem relevância, ainda que, como escreve Geraldi (1985, p. 42):

Em geral, quando se fala em ensino, uma questão que é prévia - para que ensinamos o que ensinamos? E sua correlata para que as crianças aprendem o que aprendem? - é esquecida em benefício de discussões sobre o como ensinar, o quando ensinar, o que ensinar, etc. Parece-me, no

\footnotetext{
${ }^{72}$ No sentido que Bourdieu (2002, p. 20) atribui a campo: "Minha hipótese consiste em supor que entre esses dois pólos (contexto textual e contexto social) muito distanciados, entre os quais se supõe, um pouco imprudentemente, que a ligação possa se fazer, existe um universo intermediário que chamo o campo literário, artístico, jurídico ou científico, isto é, o universo no qual estão inseridos os agentes e as instituições que produzem, reproduzem ou difundem a arte, a literatura ou a ciência." (grifos do autor).
} 
entanto, que a resposta ao 'para quê?' é que dará as diretrizes básicas das respostas às demais questões. (grifos do autor).

Assim, neste capítulo, serão discutidos:

- Para que se estuda LP (Língua Portuguesa)?

- O que se estuda em LP?

- O que é gramática?

- Qual o seu papel no ensino de LP?

na expectativa de se traçar um panorama de como são/estão orientadas as práticas pedagógicas nessa disciplina.

Dada a diversidade de seus entendimentos, foram eleitos alguns pontos de vista a partir dos quais se discute a questão:

(1) Pesquisas sobre as práticas efetivas dos professores em sala de aula, baseadas nos trabalhos das lingüistas Neves (2003) e Semeghini-Siqueira (1998 e 2006a).

(2) O desempenho dos alunos, na medida em que isso possa ser inferido pelos exames oficiais, como o SARESP, a Prova Brasil e o PISA (internacional).

(3) Sugestões dos documentos oficiais, em especial, dos PCN de Língua Portuguesa dos terceiro e quarto ciclos.

(4) Observações de autores cujas obras são referência nos meios acadêmicos de maior prestígio do país.

Esses pontos serão discutidos na tentativa de situar este trabalho em relação àquelas correntes de pensamento com as quais se identifica - quer seja porque lhe serviram de amparo teórico, quer seja porque representam os modelos aos quais se busca alternativas.

Em um segundo momento, neste capítulo, há a exposição dos fundamentos teóricos que serviram de base para a proposta que será apresentada no capítulo 6.

\subsection{Gramática e aula de Português: são a mesma coisa?}




\subsubsection{Na perspectiva da TRADIÇÃO ESCOLAR}

“Ensinar gramática. É possível? É desejável? E é exatamente o quê?” (NEVES, 2003, p. 9). Foi partindo dessas perguntas que Neves pesquisou seis grupos de professores de Língua Portuguesa de $1^{\circ}$ e $2^{\circ}$ graus (nomenclatura utilizada na época da primeira publicação de seu estudo, em 1990), em quatro cidades do estado de São Paulo, compreendendo 170 entrevistados.

A segunda pesquisa que serviu de referência para as considerações sobre a tradição escolar da disciplina de Língua Portuguesa foi a de Semeghini-Siqueira (1997, 2006a), realizada com base em cinco corpora diferentes, compostos por entrevistas com professores de Português (corpus II e III), professores das demais disciplinas (corpus I) e por relatórios de estágio para a disciplina de Metodologia do Ensino de Língua Portuguesa na Faculdade de Educação da USP (corpus V). Esse trabalho abrangeu impressões acerca das práticas de ensino e aprendizagem de Língua Portuguesa desde a década de 50 até a de 90.

Os resultados de ambas as pesquisas foram muito semelhantes, e revelam que a gramática (normativa e trabalhada em sala de aula por meio de exercícios metalingüísticos) ocupa a maior parte do tempo de aula, 60\%, (SEMEGHINI-SIQUEIRA, 2006a, p. 7), além de ser o cerne da maioria das atividades que ali se desenvolvem (SEMEGHINI-SIQUEIRA, 2006a, p. 6). Mesmo assim, nem os próprios professores entrevistados acreditavam que o seu ensino fosse capaz de melhorar as habilidades de leitura e escrita de seus alunos (NEVES, 2003, p. 47).

Por outro lado, a defesa do ensino da "gramática escolar" continua propagada por autores cuja falta de embasamento teórico é proporcionalmente inversa a sua popularidade na mídia:

As línguas que têm forma escrita, como é o caso do português, necessitam da gramática normativa para que se garanta a existência de um padrão lingüístico uniforme no qual se registre a produção cultural. Conhecer a norma culta é, portanto, uma forma de ter acesso a essa produção cultural e à linguagem oficial. Esta gramática é dedicada ao ensino da norma culta da língua portuguesa em sua vertente brasileira. (CIPRO NETO, INFANTE, 1998, p. 13). 
Ainda que se compreenda o poder da mídia enquanto "[...] um poder muito relativo e que consiste menos em manipular, e mais em saber observar, descobrir o que está se passando" (MARTÍN-BARBERO, 1995, p.48), seu papel na formação da opinião pública é, sem dúvida, privilegiado. Reflexo disso são as opiniões reiteradas, e verificadas por Neves (2003), de que "Quem lê interioriza as regras gramaticais básicas e aprende a organizar o pensamento." (LIMA, 2001, p. 105) ou de que "o domínio da língua impulsiona a carreira" (capa da Revista Veja de 12/09/2007 ${ }^{73}$ ).

4.1.1.1. Para que se estuda Língua Portuguesa, na perspectiva da tradição escolar?

Segundo a pesquisa de Neves (2003, p.10), para:

(1) Melhorar a expressão, a comunicação e a compreensão (50\% dos entrevistados);

(2) Maior correção, conhecimento de regras ou de normas do padrão culto $(30 \%)$;

(3) E $20 \%$ deles acreditam que para aquisição de estruturas da língua/apreensão de padrões da língua/sistematização do conhecimento da língua.

Outras indicações sobre a utilidade da gramática aprendida, segundo os sujeitos da pesquisa de Neves (2003, p. 10), dizem respeito a:

- Ser aprovado em concursos e vencer na vida.

- Expressar-se corretamente e ser bem aceito na sociedade.

- Usar a língua padrão/norma culta e ser bem-sucedido na vida.

A confusão entre saber falar sobre a língua e dominar os recursos expressivos da língua aparece claramente nas opções de resposta dos professores. Como decorrência disso, toda prática de ensino de Língua Portuguesa acaba afetada, porque se promete algo (falar, ler e escrever melhor) por meio de um instrumento que, a priori, não será capaz de suprir as necessidades primordiais para a realização bem sucedida dessa tarefa. Sobre esse fato, Perini (2005, p. 51) observa que "[...] os alunos percebem isso com bastante clareza, embora talvez não possam explicitar; e esse é um dos fatores do descrédito da disciplina [de Português] entre eles".

${ }^{73}$ VEJA. São Paulo, BR: Ed. Abril, 12/09/2007. 
Outro problema na base do discurso dos professores é a justificativa de se ensinar gramática como meio de ascensão social. Mais uma vez, a confusão entre saber utilizar a língua portuguesa de forma adequada (para ler, interpretar corretamente o que leu e escrever de forma apropriada) e saber gramática parece estar na base desse tipo de julgamento. Ainda que em todos os concursos públicos Língua Portuguesa seja matéria obrigatória, pouquíssimos deles, atualmente, têm questões relacionadas a conhecimentos metalingüísticos. Além disso, como ironiza Bagno (1999, p. 69): "Ora, se o domínio da norma culta fosse realmente um instrumento de ascensão na sociedade, os professores de Português ocupariam o topo da pirâmide social, econômica e política do país, não é mesmo?”

\subsubsection{Segundo a tradição escolar, o que se estuda em Língua Portuguesa?}

Por meio de relatórios de estágio, Semeghini-Siqueira (2006a, p. 7) chegou à constatação de que $60 \%$ do tempo de aula são utilizados em atividades relacionadas à GRAMÁTICA 3 (atividades com metalinguagem) ${ }^{74}, 30 \%$ em leitura (18\% com textos do livro didático, e o restante em textos fotocopiados, livros de literatura, atividades com jornal) e $10 \%$ em redação.

Quanto à leitura, Semeghini-Siqueira (2006a, p. 5) relata uma mudança positiva e gradual em dois aspectos fundamentais durante os 50 anos a que sua pesquisa se refere: a indicação de leitura em si e a forma como é avaliada. Ao longo desse tempo, a leitura passou a ocupar espaço na sala de aula, pois, no início do período pesquisado, só ocorria como lição de casa. Há, também, indícios na década de 90 de que as provas começaram a ceder espaço para atividades mais significativas, como debates, júri simulado, etc. (SEMEGHINI-SIQUEIRA, 1998, p. 2).

Porém, “[...] a periodicidade com que os exercícios de GRAMÁTICA 3 eram realizados, a partir das lições escritas na lousa ou transcritas do livro didático adotado, evidenciou-se como a característica mais forte da disciplina desde a década de 50 até a década de 90." (SEMEGHINI-SIQUEIRA, 2006a, p. 6). A afirmação também é corroborada pela pesquisa de Neves (2003, p.12), que constatou que $100 \%$ dos professores entrevistados utilizavam-se de

\footnotetext{
${ }^{74} \mathrm{O}$ conceito de GRAMÁTICA 3 será abordado na seção 4.2. Grosso modo, trata-se de um entendimento de que gramática envolve metalinguagem associada à norma padrão.
} 
exercícios metalingüísticos em suas aulas. Mais do que isso, "[...] as aulas de gramática consistem numa simples transmissão de conteúdos expostos no livro didático em uso" (NEVES, 2003, p. 12). Segundo Neves (2003, p.13) ainda, mais de 60\% das aulas foram gastas em "[...] exercícios relativos ao reconhecimento (e classificação) de classes de palavra e das funções sintáticas." Esse reconhecimento e classificação limitaram-se à aplicação de definições (na maioria das vezes, apenas nocionais) que haviam sido expostas pelos professores antes de serem realizados os exercícios (NEVES, 2003, p. 15).

Com relação à escrita em sala de aula, restringiu-se, segundo Semeghini-Siqueira (2006a, p. 7), a prática da redação, isto é, a elaboração de um texto individual ou em grupo sobre um tema, sem a orientação clara de um gênero a ser trabalhado. A correção clássica - com os "erros" em tinta vermelha e a nota - atravessou todas as décadas da pesquisa, enquanto o procedimento de "passar a limpo" a redação (que pode ser considerado um exercício de reescrita individual) perdeu força nas últimas décadas, representando a perda de uma oportunidade importante para o aluno refletir sobre a língua.

\subsubsection{O que é a gramática, segundo a tradição escolar?}

A noção dos professores, sujeitos da pesquisas já mencionadas (SEMEGHINI-SIQUEIRA, 1998, 2006a) e (NEVES, 2003), a respeito do que é gramática pode ser resumida nessas duas “definições" de Neves (2003, p. 40):

1. Gramática como um conjunto de regras de bom uso (=gramática normativa).

2. Gramática como descrição das entidades da língua e suas funções (gramática descritiva).

A lingüista (NEVES, 2003, 41) ainda explica que, por "descrição das entidades e funções", entende-se definição dos termos gramaticais e não propriamente da descrição da língua em uso. Em nenhum momento a gramática é vista para além do âmbito da metalinguagem.

Essa mesma associação entre gramática e metalinguagem parece estar disseminada na opinião pública, como pode ser atestado em artigo publicado pela Veja (AZEVEDO, 2007, p. 98), por ocasião das discussões sobre a reforma ortográfica: 
A moda chegou por aqui na década de 70 , espalhou-se como praga divina e contribuiu para formar gerações de analfabetos funcionais: as escolas renunciaram á gramática e, em seu lugar, passaram a ensinar uma certa 'Comunicação e Expressão', pouco importando o que isso significasse conceitualmente em sua grosseira redundância. Na prática, o aluno não precisava mais saber o que era um substantivo; bastava, dizia-se, que soubesse emprega-lo com eficiência e, atenção para a palavra mágica, 'criatividade'. (grifo nosso)

4.1.1.4. Como essa gramática é "ensinada/aprendida”, segundo a tradição escolar?

O livro didático, tanto na pesquisa de Neves (2003, p.18), quanto na de Semeghini-Siqueira (2006c, p. 9), é o principal recurso utilizado para a introdução do tópico gramatical, responsável também pela seqüenciação do conteúdo e fonte de exercícios.

Apesar disso, Neves (2003, p. 18) identifica também que “[...] uma das preocupações dos professores [...] é afirmar a opção pelos textos, como ponto de partida da exercitação gramatical. [...] O que se verificou, porém, nas entrevistas, foi que 'a partir do texto' nada mais representa que 'retirar de textos' unidades (frases ou palavras) para análise e catalogação."

Segundo Neves (2003, p. 30), essa preocupação pode ser vista como um dos resultados dos programas de curto prazo de atualização que muitos desses professores têm freqüentado nos últimos anos. Embora eles consigam “[...] despertar os professores para certos problemas, oferecer caminhos para posterior desenvolvimento, indicar bibliografia [...]" enfim, criar interesse por outras formas de se ensinar e aprender, "[...] findo o curso, o professor volta a sua rotina [...]” com “[...] meia dúzia de exercícios 'diferentes' que passam a conviver com os que têm cadeira cativa nas atividades".

Outro exemplo do descompasso entre aquilo que os professores acreditam ser ideal e o que realmente praticam pode ser encontrado na pesquisa que Semeghini-Siqueira (2006a, p. 9) conduziu, contrastando respostas de questionários entregues a professores de Língua Portuguesa e relatórios de observação de aula da mesma disciplina. Nesses questionários, $34 \%$ daqueles professores diziam basearem-se em "[D] avaliação diagnóstica do desempenho do aluno" e $23 \%$ afirmaram que a maior influência que sofriam era do "[J] envolvimento pessoal intenso com a leitura e escrita". Com relação aos tópicos "[A] força da tradição" e 
"[E] pressões (do livro didático)", ocorreram 15\% e 1\% de indicações, respectivamente. Por outro lado, a realidade observada em sala de aula, descrita pelos relatórios de estágio, era bastante diferente, apontando para os itens [A] e [E] como os principais fatores que influenciavam a aula. Esse resultado foi analisado pela pesquisadora como um paradoxo instigante: se "um número expressivo de docentes 'sabe' (de forma consciente ou nãoconsciente) que o ponto de partida deveria ser a capacidade de uso da língua pelos alunos, porque o professor não coloca em prática esse saber?”' (SEMEGHINI-SIQUEIRA, 2006a, p. 9).

\subsubsection{Qual o papel do ensino de Língua Portuguesa, segundo a tradição escolar?}

Analisados os dados e as reflexões expostas anteriormente, depreende-se que se, por um lado, os professores de Língua Portuguesa têm consciência de que suas aulas não estão realmente ajudando os alunos a desenvolverem suas capacidades expressivas a contento; por outro, "“...] mantêm as aulas sistemáticas de gramática como um ritual imprescindível à legitimação de seu papel" (NEVES, 2003, p. 48).

Segundo as considerações de Neves (2003, p. 45-48), isso acontece porque "[...] é como se o professor, com aulas regulares de gramática, provesse para si um álibi para o caso de uma falta de progresso do aluno na apropriação que este deve fazer, gradativamente, dos recursos da língua [...]", uma vez que a prática de ensino de gramática, nos termos aqui já expressos, está enraizada na tradição escolar e, mesmo não "servindo para nada," legitima um determinado conhecimento estável (e previsível) que deve ser esperado tanto do professor quanto do aluno.

Travaglia (1996, p. 106), comentando essa observação de Neves (2003), acrescenta:

Talvez essa resistência obstinada à mudança se deva sobretudo ao que bem lembraram Possenti e Ilari (1987): a imagem que a sociedade tem do ensino de língua materna e de como deve ser o professor leva cada professor a repetir um modelo recebido, buscando mais legitimar o seu papel (como acabamos de registrar nas observações de Neves) do que fazer algo que represente um ensino significativo para a vida de seus alunos.

Nesse sentido, a gramática funciona como expressão do poder dominante: do professor (que sabe [?]) sobre o aluno (que não sabe), dos alunos que sabem (?) sobre os que não sabem, da 
norma culta sobre as variações lingüísticas, e de uma tradição escolar sobre a própria consciência do professor.

\subsubsection{O que revelam as AVALIAÇÕES OFICIAIS sobre o Ensino Fundamental?}

A comparação dos resultados dos diversos instrumentos de avaliação do processo de ensino e aprendizagem aplicados aos alunos do Fundamental no Brasil, e, em específico, em São Paulo, aponta para problemas bastante graves com relação à qualidade desse ensino. Ainda que tais instrumentos sejam discutíveis, tanto do ponto de vista metodológico, quanto em termos de resultados práticos (basta lembrar de que os 56,2 milhões de reais ${ }^{75}$ gastos no Prova Brasil poderiam ter sido empregados na melhoria efetiva de escolas), não se pode esquecer de que são esses os meios pelos quais o governo direciona suas políticas públicas na área da Educação.

Portanto, mesmo contendo um retrato parcial da realidade, a importância de uma avaliação é incontestável para a Educação. Por esse motivo, serão apresentadas algumas conclusões obtidas por três desses instrumentos: (1) o SARESP de $2004^{76}$, sistema de avaliação aplicado pela Cesgranrio para medir o desempenho individual de cada um dos quase cinco milhões de alunos do Ensino Fundamental e do Ensino Médio de São Paulo, com relação a habilidades de leitura e escrita, incluindo questões objetivas e uma redação; e o (2) Prova Brasil de 2005, exame que substituiu o SAEB e foi "realizado em 5.398 municípios de todas as unidades da Federação, avaliando 3.306.378 alunos de $4^{\mathrm{a}}$ e $8^{\mathrm{a}}$ séries do ensino fundamental, distribuídos em 122.463 turmas de 40.920 escolas públicas urbanas com mais de 30 alunos matriculados na série avaliada" (PROVA BRASIL, 2005) e o (3) PISA, de 2000, exame promovido em 32 países pela OCDE, Organização para Cooperação e Desenvolvimento Econômico, cujo foco, naquele ano, foi a leitura.

Segundo o SARESP de 2004, apenas $32,7 \%$ dos alunos participantes que estão entre a $5^{\text {a }}$ e a $8^{\mathrm{a}}$ séries possuem níveis adequados de leitura e escrita (ótimo, muito bom e bom). Mais alarmante ainda é saber que quase o mesmo número, 30,3\%, se encontra na categoria dos

\footnotetext{
${ }^{75}$ Informação obtida em: MARQUES, C. Nova avaliação da educação básica será a mais cara do país. Folha de São Paulo, São Paulo, 02 maio 2005, Folha Online. Disponível em: $<$ http://www1.folha.uol.com.br/folha/educacao/ult305u17447.shtml > Último acesso em 20/01/ 2007.

${ }^{76}$ No momento em que este texto foi escrito, os dados de 2005 ainda não haviam sido disponibilizados ao público em geral.
} 
"insuficientes" e "abaixo de insuficiente" - que conta com quase $18 \%$ desse total. Os demais obtiveram desempenho "regular",77.

Isso significa que dois terços de todos os alunos do Fundamental II conseguem “[...] reconhecer o tema de um texto de opinião [...]”, por exemplo, mas não “[...] conseguem inferir informações implícitas nessas opiniões [...]” nem “[...] fazer conexões entre essas opiniões e gráficos [...]”. Desses, um terço “[...] compreende uma história em quadrinhos estabelecendo relações entre imagem e texto [...]", mas não "[...] consegue estabelecer relação entre os mesmos recursos em uma propaganda[...]" (SARESP, 2004).

Os resultados do Prova Brasil $2005^{78}$ são semelhantes. São Paulo, $12^{\mathrm{a}}$ colocada entre as 26 capitais participantes, obteve desempenho abaixo da média brasileira com relação à leitura escrita. Foram 220,09 pontos de 350 possíveis.

Esse resultado leva a duas considerações bastante intrigantes:

(1) A afirmação de que a carência de meios influi diretamente na qualidade da educação oferecida, ainda que seja bastante lógica e razoável, não se sustenta como única razão para o baixo desempenho escolar, como é possível deduzir por meio dos dados dessa pesquisa. Sendo São Paulo a cidade mais rica do país, seus resultados ficaram muito aquém de seu poder econômico, ainda que não se tenha sido realizada uma análise específica das condições materiais de cada escola.

(2) Há de se inferir, então, sobre outras razões que influenciaram o mau desempenho desses alunos. Certamente a questão de como estão estruturadas essas aulas e qual o nível de envolvimento/comprometimento desses alunos e professores deve ser considerada para que uma análise mais conclusiva sobre esses dados possa ser feita. Infelizmente, porém, não são dados dos quais se dispõe nessas pesquisas. Sabe-se apenas que a escola com melhor colocação no exame (para $4^{\mathrm{a}}$. série) foi Escola Municipal Professor Cândido Vilhena, localizada no Pará, em uma região sem água encanada nem esgoto. Porém, segundo a diretora da escola, Nazareth Vilhena, o

\footnotetext{
${ }^{77}$ Dados disponíveis em: http://www.educacao.sp.gov.br/noticias_2005/2005_06_27_arquivo02.ppt (último acesso em 22/01/2007)

${ }^{78}$ Disponível em: http://www.inep.gov.br/basica/SAEB/prova brasil/index.html (último acesso em 22/01/2007)
} 
sucesso no exame pode ser atribuído a quatro fatores: o engajamento da comunidade nos assuntos da escola, a introdução de "metodologia que utiliza atividades lúdicas no processo de alfabetização, em lugar da aula expositiva no quadro-negro", a formação continuada dos professores e a parceria entre a escola e a universidade na realização de estágios supervisionados (BARROS, 2006).

Assim, segundo o Prova Brasil, no nível de letramento em que São Paulo se encontra, a média dos alunos sabe, por exemplo, “[...] identificar diferentes personagens em um texto literário [...]", mas não é capaz de "[...] distinguir opiniões distintas emitidas por eles, [...]" nem de "[...] estabelecer relação entre as partes de um texto, identificar a tese de textos ou diferenciar a parte principal das secundárias em texto informativo que recorre à exemplificação [...]" (PROVA BRASIL, 2005).

Ao serem comparados ambos os exames, algumas constatações chamam à atenção, entre elas a de que a grande maioria dos alunos submetidos aos exames não consegue entender metáforas, estabelecer relações de causa e conseqüência, relacionar gráfico com texto nem separar fatos de opiniões.

Diante dessa realidade, não é de se estranhar que o Brasil tenha amargado o último lugar entre os 32 países que tomaram parte, em 2000, do PISA (Programa Internacional de Avaliação de Estudantes). Embora os resultados desse exame de 2003 já tenham sido divulgados, preferiuse recorrer aos dados de 2000 pelo fato de focalizarem a leitura, enquanto aquele, os conhecimentos matemáticos. No PISA 2003, entretanto, houve um "avanço" na posição do Brasil em relação aos demais, então, 37 países - foi o antepenúltimo, ficando apenas na frente da Indonésia e da Tunísia.

Dentro do nível de proficiência 1, aquele em que o Brasil se enquadrou com seus 396 pontos de 698, os alunos se mostraram capazes de "[...] localizar informações explícitas em um texto, reconhecer o tema principal ou a proposta do autor, construir uma conexão simples entre uma informação expressa em um texto de uso cotidiano e outras já conhecidas [...]" (PISA, 2000, p. 59), mas não conseguiram fazer inferência a partir de um texto, construir relações que extrapolem os limites do que está apenas escrito no próprio texto, formular hipóteses a partir daquilo que leu nem avaliar criticamente um texto. 
Essas constatações deixam explícita a triste realidade de que, embora encontrem as informações que necessitam no texto, os estudantes brasileiros não sabem utilizá-las, mostrando-se incapazes de compreendê-las funcionalmente. O resultado do PISA, portanto, apenas identificou aquilo que os exames nacionais também acabaram por comprovar: a distância abissal entre o ensino das escolas brasileiras e a necessidade real do desenvolvimento das habilidades capazes de tornar os alunos brasileiros não apenas em cidadãos instrumentalizados, mas sujeitos de suas ações, capazes de interagir adequadamente com/na sociedade em que vivem.

Essa realidade, bastante distante temporalmente daquela vivida no início do século, parece ainda abrigar o mesmo modelo de escola, tal é a atualidade do poema de Drummond ${ }^{79}$, "Aula de Português":

[...] professor Carlos Góes, ele é quem sabe,

E vai desmatando

O amazonas de minha ignorância

Figuras de gramática, esquipáticas,

Atropelam-me, aturdem-me, seqüestram-me

$[\ldots]$

O português são dois: o outro, mistério.

\subsubsection{Na PERSPECTIVA OFICIAL}

Previstos pela Constituição de 1988 e subordinados à Lei de Diretrizes e Bases (Lei no 9.394/96, de 20/12/96), os Parâmetros Curriculares Nacionais (PCN) constituem hoje a principal referência em termos oficiais com relação à Educação no país. Os PCN são compostos por sugestões "temáticas" e "estruturais" que servem como base para os municípios e estados elaborarem seus currículos.

Os PCN para a área de Língua Portuguesa, especificamente, “[...] focalizam a necessidade de dar ao aluno condições de ampliar o domínio da língua e da linguagem, aprendizagem fundamental para o exercício da cidadania” (BRASIL, PCN - LÍNGUA PORTUGUESA TERCEIRO E QUARTO CICLOS, 1998, p. 32).

\footnotetext{
${ }^{79}$ DRUMMOND DE ANDRADE, C. Aula de Português. In: Esquecer para lembrar. Rio de Janeiro: Record,
} 1979. 
Para tanto, várias recomendações são feitas pelo documento no sentido de orientar caminhos para que essa meta se torne aplicável à prática escolar. A grande crítica, porém, comumente feita a esse documento é justamente a generalidade dessas recomendações, tendo pouco subsídio sobre como elas poderiam ser implantadas. (MILLER, 1998, p. 77).

\subsubsection{Para que se estuda Língua Portuguesa, segundo os PCN?}

Segundo os PCN de Língua Portuguesa referentes aos terceiro e quarto ciclos (1998, p. 49), o ensino e aprendizagem dessa disciplina orienta-se em três eixos de estudos: a fala/escuta, a leitura/escrita e a análise lingüística. Os objetivos para cada uma dessas habilidades, expressos no documento, são:

\section{No processo de escuta de textos orais, espera-se que o aluno:}

- amplie, progressivamente, o conjunto de conhecimentos discursivos, semânticos e gramaticais envolvidos na construção dos sentidos do texto;

- reconheça a contribuição complementar dos elementos não-verbais (gestos, expressões faciais, postura corporal);

- utilize a linguagem escrita, quando for necessário, como apoio para registro, documentação e análise;

- amplie a capacidade de reconhecer as intenções do enunciador, sendo capaz de aderir a ou recusar as posições ideológicas sustentadas em seu discurso.

\section{No processo de leitura de textos escritos, espera-se que o aluno:}

- saiba selecionar textos segundo seu interesse e necessidade;

- leia, de maneira autônoma, textos de gêneros e temas com os quais tenha construído familiaridade:

a) selecionando procedimentos de leitura adequados a diferentes objetivos e interesses, e a características do gênero e suporte;

b) desenvolvendo sua capacidade de construir um conjunto de expectativas (pressuposições antecipadoras dos sentidos, da forma e da função do texto), apoiando-se em seus conhecimentos prévios sobre gênero, suporte e universo temático, bem como sobre saliências textuais

- recursos gráficos, imagens, dados da própria obra (índice, prefácio etc.);

a) confirmando antecipações e inferências realizadas antes e durante a leitura;

b) articulando o maior número possível de índices textuais e contextuais na construção do sentido do texto, de modo a:

i) utilizar inferências pragmáticas para dar sentido a expressões que não pertençam a seu repertório lingüístico ou estejam empregadas de forma não usual em sua linguagem;

ii) extrair informações não explicitadas, apoiando-se em deduções;

iii) estabelecer a progressão temática;

iv) integrar e sintetizar informações, expressando-as em linguagem própria, oralmente ou por escrito;

v) interpretar recursos figurativos tais como: metáforas, metonímias, eufemismos, hipérboles etc.;

c) delimitando um problema levantado durante a leitura e localizando as fontes de informação pertinentes para resolvê-lo; 
Continuação do quadro da página anterior:

- seja receptivo a textos que rompam com seu universo de expectativas, por meio de leituras desafiadoras para sua condição atual, apoiando-se em marcas formais do próprio texto ou em orientações oferecidas pelo professor;

- troque impressões com outros leitores a respeito dos textos lidos, posicionando-se diante da crítica, tanto a partir do próprio texto como de sua prática enquanto leitor;

- compreenda a leitura em suas diferentes dimensões . o dever de ler, a necessidade de ler e o prazer de ler;

- seja capaz de aderir ou recusar as posições ideológicas que reconheça nos textos que lê.

No processo de produção de textos orais, espera-se que o aluno:

- planeje a fala pública usando a linguagem escrita em função das exigências da situação e dos objetivos estabelecidos;

- considere os papéis assumidos pelos participantes, ajustando o texto à variedade lingüística adequada;

- saiba utilizar e valorizar o repertório lingüístico de sua comunidade na produção de textos;

- monitore seu desempenho oral, levando em conta a intenção comunicativa e a reação dos interlocutores e reformulando o planejamento prévio, quando necessário;

- considere possíveis efeitos de sentido produzidos pela utilização de elementos não-verbais.

\section{No processo de produção de textos escritos, espera-se que o aluno:}

- redija diferentes tipos de textos, estruturando-os de maneira a garantir:

a) a relevância das partes e dos tópicos em relação ao tema e propósitos do texto;

b) a continuidade temática;

c) a explicitação de informações contextuais ou de premissas indispensáveis à interpretação;

d) a explicitação de relações entre expressões mediante recursos lingüísticos apropriados (retomadas, anáforas, conectivos), que possibilitem a recuperação da referência por parte do destinatário;

- realize escolhas de elementos lexicais, sintáticos, figurativos e ilustrativos, ajustando-as às circunstâncias, formalidade e propósitos da interação;

- utilize com propriedade e desenvoltura os padrões da escrita em função das exigências do gênero e das condições de produção;

- analise e revise o próprio texto em função dos objetivos estabelecidos, da intenção comunicativa e do leitor a que se destina, redigindo tantas quantas forem as versões necessárias para considerar o texto produzido bem escrito.

\section{No processo de análise linguística, espera-se que o aluno:}

- constitua um conjunto de conhecimentos sobre o funcionamento da linguagem e sobre o sistema lingüístico relevantes para as práticas de escuta, leitura e produção de textos;

- aproprie-se dos instrumentos de natureza procedimental e conceitual necessários para a análise e reflexão lingüística (delimitação e identificação de unidades, compreensão das relações estabelecidas entre as unidades e das funções discursivas associadas a elas no contexto);

- seja capaz de verificar as regularidades das diferentes variedades do Português, reconhecendo os valores sociais nelas implicados e, conseqüentemente, o preconceito contra as formas populares em oposição às formas dos grupos socialmente favorecidos.

Quadro 2 - Objetivos do ensino e aprendizagem de Língua Portuguesa no $3^{\circ}$. e $4^{\circ}$. Ciclos, segundo os PCN de Língua Portuguesa dos terceiro e quarto ciclos (1998, p. 49 - 52) 
4.1.3.2. O que se estuda em Língua Portuguesa, segundo os PCN?

Articulada em torno dos três eixos anteriormente comentados (fala/escuta, leitura/escrita e a análise lingüística), a prática recomendada pelos PCN de Língua Portuguesa para os terceiro e quarto ciclos do Fundamental II preconizam o trabalho com gêneros textuais como ponto de partida para todas as atividades de sala de aula:

[...] não é possível tomar como unidades básicas do processo de ensino as que decorrem de uma análise de estratos - letras/fonemas, sílabas, palavras, sintagmas, frases - que, descontextualizados, são normalmente tomados como exemplos de estudo gramatical e pouco têm a ver com a competência discursiva. Dentro desse marco, a unidade básica do ensino só pode ser o texto. Os textos organizam-se sempre dentro de certas restrições de natureza temática, composicional e estilística, que os caracterizam como pertencentes a este ou aquele gênero. Desse modo, a noção de gênero, constitutiva do texto, precisa ser tomada como objeto de ensino. (BRASIL, PCN LÍNGUA PORTUGUESA - TERCEIRO E QUARTO CICLOS, 1998, p. 23).

A forma como esse emprego deve ocorrer, segundo o documento, é por meio do intercâmbio entre o uso e a reflexão, esquematizado na figura 1 (BRASIL, PCN LÍNGUA PORTUGUESA - TERCEIRO E QUARTO CICLOS, 1998, p. 35).
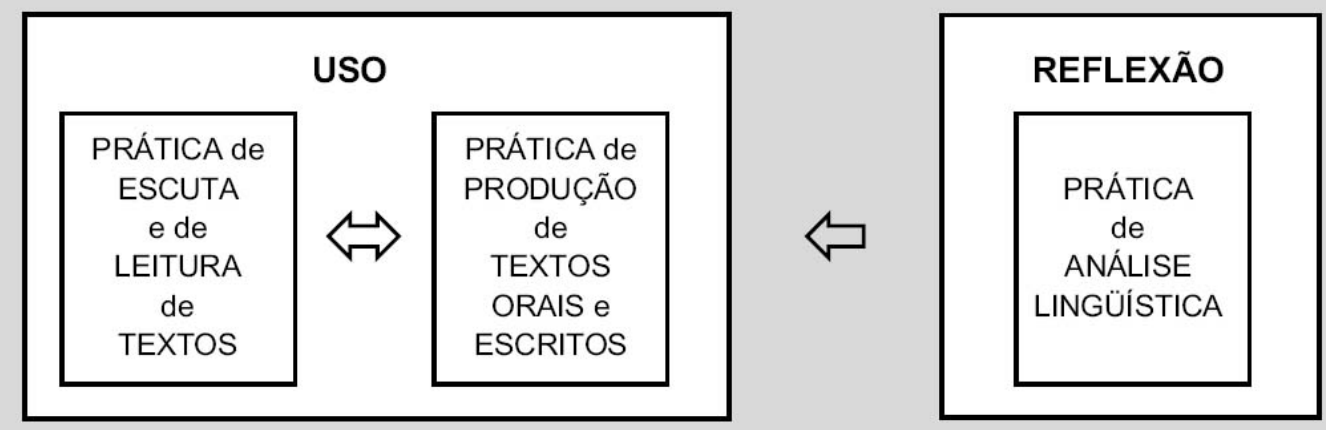

Figura 1 Procedimento para organização das situações didáticas, segundo os PCN de Língua Portuguesa dos terceiro e quarto ciclos $(1998$, p. 35$)$

Ao contemplar todas as habilidades (leitura, escrita, fala e escuta) e a análise da língua sob a perspectiva da organização do ensino e da aprendizagem por meio de gêneros textuais, os PCN abrem caminho para um ensino renovador, que não considera apenas a palavra escrita, nem o padrão culto preconizado pela gramática normativa como único conteúdo válido para ser abordado em sala de aula. 
Outro ponto positivo é o entendimento que perpassa todos os objetivos de que o uso da língua é mais importante do que o reconhecimento de categorias e classificação de estruturas.

O problema, porém, está no como esses preceitos foram integrados ao cotidiano do professor que já desempenhava sua função antes deles entrarem em vigor. As crenças pessoais sobre o papel do professor em sala de aula e o julgamento da relevância sobre aquilo que deve ou não ser selecionado como conteúdo válido para o ensino são questões que vão muito além da implantação de uma lei.

Ainda que debates, palestras, workshops, reciclagens tenham sido feitas - e sejam de grande importância - não se pode desconsiderar o fato de que quando os professores se vêem diante da sua realidade de ensino, recorrem aquilo que lhes é mais confortável e seguro. Portanto, pode-se dizer que se houver efeitos positivos decorrentes dos PCN, infelizmente demandarão muito tempo para serem incorporados às práticas educacionais.

\subsubsection{O que é gramática, segundo os $\mathrm{PCN}$ ?}

Se, por um lado, “[...] na seleção dos conteúdos de análise lingüística, [...] a referência não pode ser a gramática tradicional”, por outro, “[...] a atividade metalingüística deve ser instrumento de apoio para a discussão dos aspectos da língua que o professor seleciona e ordena no curso do ensino-aprendizagem [...]” (BRASIL, PCN LÍNGUA PORTUGUESA TERCEIRO E QUARTO CICLOS, 1998, p. 28).

Assim, ainda que a análise da língua seja preferencialmente realizada por meio de atividades lingüísticas e epilingüísticas, no $3^{\circ}$ e $4^{\circ}$ ciclos, segundo os PCN de Língua Portuguesa dos terceiro e quarto ciclos $(1998$, p. 48,49$)$ espera-se que a abordagem gramatical contemple também a metalingüística, com intuito de "[...] merecerem tratamento mais aprofundado na direção da construção de novas formas de organizá-lo [conhecimento lingüístico] e representá-lo que impliquem a construção de categorias, intuitivas ou não.”

A referência a atividades metalingüísticas não se dá no sentido de classificação de palavras ou de termos da oração, como tradicionalmente se aplica na escola. Mesmo assim, a formulação 
confusa do propósito de sua utilização, além da menção de "categorias" facilita compreensões que levem a práticas de taxionomia de palavras e frases.

\subsubsection{Qual o papel do ensino de Língua Portuguesa para os PCN?}

Ainda que nas páginas dos PCN de Língua Portuguesa dos terceiro e quarto ciclos (1998, p. 32) haja intenções claras em se fazer o aprendizado da língua uma "[...] aprendizagem [...] para o exercício da cidadania[...]", a capacitação do aluno à interação com/na sociedade em que vive, de tal forma que ele se constitua em sujeito crítico diante da vida e não apenas expectador de eventos ainda parece distante, senão do texto, mas da prática, por tudo que já foi exposto anteriormente.

\subsubsection{Na perspectiva dos ESTUDOS LINGÜÍSTICOS voltados à Educação}

Optou-se pelas idéias defendidas por Eglê Franchi (1984), Carlos Franchi (1991), Geraldi (1985, 1991, 2002), Travaglia (1996), Possenti (1996), Perini (2005), Marcuschi (2004), Fávaro, Andrade e Aquino (2000) e Semeghini-Siqueira (1997, 1998, 2001, 2005, 2006a, 2006b, 2006c), uma vez que constituem referência obrigatória para qualquer estudo sobre Educação na área de Língua Portuguesa.

\subsubsection{Para que se estuda Língua Portuguesa, na perspectiva dos ESTUDOS LINGÜÍSTICOS voltados à Educação?}

Embora haja formulações diversas pelos teóricos cujos textos serviram de base para estas considerações, a de Geraldi (1985, p. 42) parece bastante apropriada porque relaciona diretamente a finalidade do ensino e aprendizagem de Língua Portuguesa à prática de sala de aula: “[...] no caso do ensino de Língua Portuguesa, uma resposta ao 'para quê' envolve tanto uma 'concepção de linguagem' quanto uma postura relativamente à Educação. Uma e outra se fazem presentes na articulação metodológica.” [grifo do autor]

A concepção de linguagem que norteia os estudos desses autores é a de que a língua é uma forma de interação, isto é, “[...] através dela o sujeito que fala pratica ações que não conseguiria praticar a não ser falando; com ela age sobre o ouvinte, constituindo compromissos e vínculos que não pré-existiam antes da fala" (GERALDI, 1985, p. 43). Nessa 
perspectiva, a linguagem é mais do que simplesmente a expressão do pensamento (um suporte material da subjetividade), ou a comunicação de idéias (um veículo da subjetividade), é o ato da própria inter-subjetividade, o que implica, como escreve Geraldi (1985, p. 43), “[...] uma postura educacional diferenciada, uma vez que situa a linguagem como lugar de constituição de relações sociais, onde os falantes se tornam sujeitos."

Essa postura educacional se traduz por prioridades que podem ser resumidas em: (1) oferecer oportunidades igualitárias de acesso aos bens materiais e culturais disponíveis na sociedade, e (2) desenvolver as habilidades de leitura e escrita.

A primeira dessas proposições relaciona-se a escolha de se ensinar a variedade padrão na escola. Embora esses teóricos defendam que a escola não deva estigmatizar as diversas variedades lingüísticas, todos se posicionam a favor do ensino da variedade de maior prestígio, conhecida como "padrão". Isso “[...] porque a posse dessa variedade e dessa forma específica de relação com a linguagem é instrumento fundamental e indispensável na luta pela superação das desigualdades sociais.” (SOARES, $1983^{80}$ apud GERALDI, 1985, p. 45).

Portanto, não se trata de ensinar a variedade padrão porque as demais são "erradas", como fica explícito na concepção da tradição escolar, analisada anteriormente, nem porque pelo seu conhecimento seja possível ascender socialmente. Antes, oferecer chances iguais a todos os alunos, independentemente de sua origem social ou do dialeto utilizado em família, é uma condição mínima que qualquer sociedade democrática deve cumprir, “[...] desde que se aceite que a mesma língua possa servir a mais de uma ideologia, a mais de uma função, o que parece hoje evidente." (POSSENTI, 1996, p. 18).

Quanto à segunda proposição, os teóricos são unânimes em afirmar que o desenvolvimento da leitura e da escrita só pode ocorrer por meio da prática dessas habilidades, e não pela exercitação metalingüística. Nesse sentido, o estudo da gramática em sala de aula necessita de ser ressignificado. Nesse outro escopo teórico, diferentemente daquele da tradição escolar, defendida pela mídia e constatada nas salas de aula pelos trabalhos de Neves (2003) e Semeghini-Siqueira (1998, 2006a), a gramática passa a ser entendida em três níveis lingüístico, epilingüístico e metalingüístico, que serão objeto de definição na seção 4.2 deste

\footnotetext{
${ }^{80}$ SOARES, M. Aprendizagem da lingual maternal: problemas e perspectivas. Em aberto, ano2, no. $12,1983$.
} 
capítulo, e o seu estudo orientado à reflexão sobre a língua em uso, e não mais à memorização de definições.

\subsubsection{O que se estuda em Língua Portuguesa, na perspectiva dos ESTUDOS LINGÜÍSTICOS voltados à Educação?}

Evidentemente, cada um dos textos teóricos consultados traz diferentes propostas sobre o ensino e aprendizagem de Língua Portuguesa, afinal, cada um traz uma contribuição diferente aos estudos da Educação. Ainda assim, os eixos que os orientam possuem entendimentos em comum sobre:

- qual variedade lingüística deve ser objeto de estudo na escola;

- o lugar da gramática;

- a presença da fala/escuta enquanto habilidades a serem trabalhadas em sala de aula;

- a leitura e a escrita, organizadas em torno de gêneros textuais.

Mesmo não havendo unanimidade no âmbito dos estudos lingüísticos acerca do privilégio da variedade padrão em seu ensino na escola, como expõe Soares $\left(1983^{76}\right.$ apud GERALDI, 1985 , p. 45):

[...] de um lado há os que pretendem que a escola deva respeitar e preservar a variedade lingüística das classes populares, [...]. Neste caso, a escola deveria assumir a variedade lingüística das classes populares como instrumento legítimo do discurso escolar (dos professores, dos alunos e do material didático). Por outro lado, há os que afirmam a necessidade de que as classes populares aprendam a usar a variedade lingüística socialmente privilegiada, própria das classes dominantes, e aprendam a manter com a linguagem a relação que as classes dominantes com ela mantêm.

Todos os autores que serviram de base teórica para este trabalho defendem o ensino da norma padrão, pelos motivos já comentados na seção anterior. Todavia, se a opção defendida é o ensino da norma padrão, isso não significa que, para eles, a gramática deva ser entendida apenas enquanto gramática normativa. 
Como será aprofundado na próxima seção deste capítulo, a gramática, para esses autores, é constituída por uma pluralidade de entendimentos que contempla diversas formas de abordagens práticas.

Grosso modo, porém, o que defendem pode ser aglutinado nas palavras de Possenti (1996, p. 88-90):

\begin{abstract}
A primeira tarefa da escola, do ponto de vista do ensino da gramática, é aumentar o domínio de recursos lingüísticos por parte do aluno. Isso se faz expondo o aluno consistentemente a formas lingüísticas que ele não conhece, mas deve conhecer para ser um usuário competente da língua escrita. [...]
\end{abstract}

Em segundo lugar, em termos de prioridade, entraria a gramática descritiva. Ensinar gramática descritiva não seria, evidentemente, ensinar lingüística na escola. A proposta é a seguinte: diante do domínio lingüístico efetivo da língua que o aluno revela na escrita, ou dos problemas que manifesta em suas atividades de escrita, deve-se aprender a comparar e/ou propor diversas possibilidades de construção. A proposta consiste em trabalhar os fatos da língua a partir da produção efetiva do aluno. [...]

A comparação sem preconceito das formas é uma tarefa da gramática descritiva. E a explicitação da aceitação ou rejeição social de tais formas é uma tarefa da gramática normativa. As três podem evidentemente conviver na escola.

Não se trata, portanto, de eliminar os estudos de gramática de sala de aula, mas sim, redefinir, não somente o seu espaço, mas também, o que se entende por gramática.

Dessa forma, o domínio da língua escrita e, por conseguinte, da leitura não se pretende ser atingido pela exercitação de estruturas gramaticais. Antes, é pelo uso, pela constante reescrita e releitura que esses autores entendem que o aluno pode ser levado ao domínio adequado dessas habilidades. Desarte, defende-se que o ensino e a aprendizagem de Língua Portuguesa seja propositivo - levem o aluno a ler/escrever, falar/ouvir melhor - e propositado - faça sentido para o aluno, e não fique apenas no reconhecimento e classificação de palavras e frases.

Para tanto, o texto também deixa de estar confinado apenas à dimensão escrita. Para Marcuschi (2004, p. 42), o oral e o escrito estão em um contínuo, de forma que o desenvolvimento de um auxilia o outro: 
O contínuo dos gêneros textuais distingue e correlaciona os textos de cada modalidade (fala e escrita) quanto às estratégias de formulação que determinam o contínuo das características que produzem as variações das estruturas textuais-discursivas, seleções lexicais, estilo, grau de formalidade etc., que se dão num contínuo de variações, surgindo daí semelhanças e diferenças ao longo de contínuos sobrepostos. (grifos do autor)

Fávero, Andrade e Aquino (2000, p.12) também chamam à atenção à importância da produção de textos orais, que são meio por excelência da interação entre pessoas - da troca de idéias, experiências, opiniões, etc. Seu lugar na sala de aula:

[...] não se trata obviamente de "ensinar a fala", mas de mostrar aos alunos a grande variedade de usos da fala, dando-lhes a consciência de que a língua não é homogênea, monolítica, trabalhando com eles os diferentes níveis (do mais coloquial ao mais formal) das duas modalidades - escrita e falada.

Auxiliando, assim a percepção do aluno acerca da variação lingüística e da questão dos níveis da fala, isto é, dos níveis de formalidade e que perpassam a fala, segundo o contexto de sua enunciação.

\subsubsection{O que é gramática, para os ESTUDOS LINGÜÍSTICOS voltados à Educação?}

Entre os textos dos autores pesquisados, o de Travaglia (1996, p. 30-33) é o que traz a maior abrangência de entendimentos sobre a gramática. Por esse motivo, estão reproduzidas no Quadro 3, em linhas gerais, as definições que esse autor emprega para o termo, segundo cada corrente de estudo.

Travaglia (1996, p. 34) chama à atenção, porém, ao fato de que há outras três (implícita, explícita e reflexiva) que diferem das transpostas anteriormente pelos critérios de sua proposição, ligados à estrutura e aos mecanismos de funcionamento da língua. Por esse motivo, consistem mais em procedimentos de análise da língua do que propriamente concepções sobre o que deva ser a gramática. Portanto, não se excluem das três primeiras (normativa, descritiva e internalizada), mas se identificam com elas em certa medida. 
A gramática normativa, que é aquela que estuda apenas os fatos da língua padrão, da norma culta de uma língua, norma essa que se tomou oficial, baseia-se, em geral, mais nos fatos da língua escrita e dá pouca importância à variedade oral da norma culta, que é vista, conscientemente ou não, como idêntica à escrita. Ao lado da descrição da norma ou variedade culta da língua (análise de estruturas, uma classificação de formas morfológicas e léxicas), a gramática normativa apresenta e dita normas de bem falar e escrever, normas para a correta utilização oral e escrita do idioma, prescreve o que se deve e o que não se deve usar na língua. Essa gramática considera apenas uma variedade da língua como válida, como sendo a língua verdadeira. [...]

A gramática descritiva é a que descreve e registra para uma determinada variedade da língua em um dado momento de sua existência (portanto numa abordagem sincrônica) as unidades e categorias lingüísticas existentes, os tipos de construção possíveis e a função desses elementos, o modo e as condições de uso dos mesmos. Portanto a gramática descritiva trabalha com qualquer variedade da língua e não apenas com a variedade culta e dá preferência para a forma oral desta variedade. Podemos, então, ter gramática descritiva de qualquer variedade da língua. [...]

A gramática internalizada ou competência lingüística internalizada do falante é o próprio "mecanismo", o conjunto de regras que é dominado pelos falantes e que lhes permite o uso normal da língua (cf. Perini, 1976, p.20 e 22). Na verdade é essa gramática que é objeto de estudo dos outros dois tipos de gramática, sobretudo da descritiva. [...]

Quadro 3 - Entendimentos sobre o que é gramática, segundo Travaglia (1996, p. 30-33)

Todos os demais autores consultados procuram ater suas considerações sobre esses três primeiros "tipos" de gramática relacionados por Travaglia (1996) (normativa, descritiva e internalizada), sendo que Semeghini-Siqueira (2005) as associa ainda a três níveis de operações com a linguagem - o lingüístico, o epilingüístico e o metalingüístico, explicitado no

Quadro 4:

GramáticA 1: INTERNALIZADA. Trata-se de aprendizagem associada a operações nãoconscientes, intuitivas, subjacentes ao uso da língua na interação com o outro. Refere-se a atividades lingüísticas, tais como: falar, escutar, ler e escrever. [...]

GRAMÁtiCa 2: NÃO-SISTEMATIZADA. Trata-se de propor atividades que focalizem a própria linguagem como objeto de operações transformadoras, que viabilizem uma reflexão sobre a linguagem, ou melhor, sobre as diferentes formas de dizer. O objetivo é ensinar/aprender a usar os recursos expressivos da língua, por meio de operações mentais predominantemente conscientes, sem recorrer a "termos técnicos" / a nomenclaturas nem a classificações. Nesta prática, os enunciados são confrontados e transformados de forma lúdica. São consideradas atividades epilingüísticas, por exemplo, a ampliação ou redução de elementos de um texto e, sobretudo, a reescrita/reelaboração. Certamente, as atividades com GRAMÁTICA 1 e GRAMÁTICA 2 estão interligadas. Podemos estabelecer entre elas um continuиm. [...]

Gramática 3: SistematizadA. Pode-se dizer que constituem exercícios que requerem operações conscientes, reflexões sobre a língua e abarcam componentes descritivos e normativos, recorrendo-se ao uso de 'terminologia técnica'. Tais exercícios correspondem às atividades metalingüísticas. Trata-se do ensino da "gramática escolar", da "gramática pela gramática" sem haver uma preocupação com a atividade discursiva.[...] (grifos da autora).

Quadro 4 - Aprender e ensinar Gramática 1-2-3 na escola: qual? quanto? como? para quê?

(Semeghini-Siqueira, 2005, p. 4) 
A grande diferença entre essas definições e aquela praticada pela tradição escolar está em não considerar a gramática um objeto de estudo único, nem única a sua perspectiva de trabalho. Não se trata de um compêndio com as normas cristalizadas do "bem escrever", mas sim, de abordagens distintas que procuram compreender as regras que subjazem à língua nos diferentes momentos em que a utilizamos. Essa visão mais ampla sobre a gramática possibilita uma riqueza nas práticas de sala de aula que jamais seria compatível com o entendimento restrito de gramática enquanto apenas metalinguagem.

4.1.4.4. Qual o papel do ensino de Língua Portuguesa, na perspectiva dos ESTUDOS LINGÜÍSTICOS voltados à Educação?

Para esses estudiosos, o ensino e a aprendizagem de Língua Portuguesa é a principal forma de "[...] romper com os bloqueios de acesso ao poder [...]" (GERALDI, 1985, p. 46) e promover uma sociedade mais justa - não da forma como a tradição escolar propõe, pelo simples fato de que saber a norma culta garanta o acesso a condições melhores de vida, mas porque oportuniza a todas as classes o desenvolvimento pleno das capacidades de socialização.

Em termos mais específicos, algumas orientações, relacionadas por Soares (1999, p. 56-57), perpassam os textos de todos esses teóricos:

- Promover práticas de oralidade e de escrita de forma integrada, levando os alunos a identificar as relações entre oralidade e escrita.

- Desenvolver as habilidades de uso da língua escrita em situações discursivas diversificadas em que haja:

- motivação e objetivo para ler textos de diferentes tipos e gêneros e com diferentes funções;

- motivação e objetivo para produzir textos de diferentes tipos e gêneros, para diferentes

interlocutores, em diferentes situações de produção.

- Desenvolver as habilidades de produzir e ouvir textos orais de diferentes gêneros e com diferentes funções, conforme os interlocutores, os seus objetivos, a natureza do assunto sobre o qual falam ou escrevem, o contexto, enfim, as condições de produção do texto oral ou escrito.

- Criar situações em que os alunos tenham oportunidades de refletir sobre os textos que lêem, escrevem, falam ou ouvem, intuindo, de forma contextualizada, a gramática da língua, as características de cada gênero e tipo de texto, o efeito das condições de produção do discurso na construção do texto e de seu sentido.

- Desenvolver as habilidades de interação oral e escrita em função e a partir do grau de letramento que o aluno traz de seu grupo familiar e cultural, uma vez que há uma grande diversidade nas práticas de oralidade e no grau de letramento entre os grupos sociais a que os alunos pertencem - diversidade na natureza das interações orais e na maior ou menor presença de práticas de leitura e de escrita no cotidiano familiar e cultural dos alunos. 


\subsection{Crítica ao ensino e aprendizagem de gramática no Fundamental II}

Diante da discrepância entre os objetivos defendidos para o ensino e a aprendizagem de gramática pelos estudiosos cujos textos serviram de base para a elaboração desta proposta, e as práticas referidas por Neves (2003) e Semeghini-Siqueira (1998, 2006a) e reiteradas pelas observações durante a Entrada em Campo, descritas no capítulo 5 deste trabalho, faz-se indispensável a menção à crítica desses teóricos às práticas da tradição escolar.

Assim, Perini (2005, p. 48) identifica alguns sintomas de que “[...] alguma coisa está muito errada [...]" no ensino de gramática na escola. O primeiro deles é que “[...] uns sustentam que a gramática 'não serve para nada' [...], [enquanto outros, dizem que] sem gramática não é possível aprender português". O tudo ou nada dessas proposições, longe de contribuir para avanços nas discussões a respeito do lugar da gramática na escola, simplesmente expõe a fragilidade de seus argumentos, de base ideológica, e não teórica.

Outros dois "índices” do problema também são apontados por Perini (2005, p.48) nos seguintes termos: “Quantos (jovens) sonham em ser gramáticos?” e, ainda pior do que isso, depois de pelo menos nove anos estudando gramática, “[...] ao chegar ao terceiro colegial, (o aluno) continua estudando a análise sintática e as classes de palavras - e continua não sabendo." (PERINI, 2005, p. 48)

O desinteresse pelo estudo da gramática, assim como a própria falta de progresso na matéria também são os motivos apontados, principalmente por Possenti (1996) e Franchi (1991), para a necessidade da renovação de seus estudos na escola. Possenti (1996, p. 40) ainda acrescenta que a atualização dos próprios compêndios se faz premente: “[...] todos perceberíamos que gastar um tempo enorme com regências e colocações inusitadas é, a rigor, inútil. A prova é que a maioria dos que estudam não aprendem tais formas, ou, pelo menos, não as usa; [...]" enquanto Franchi (1991, p.27) chama à atenção ao caráter redutor da análise que se faz da gramática na escola:

$[\ldots]$

- apesar de tudo o que tem sido dito pela lingüística e pela pedagogia, mantém-se um viés normativo que não se limita a levar os alunos ao domínio da modalidade culta e escrita (um dos objetivos da escola), mas 
que constitui um fator importante de discriminações e repressão lingüísticas;

- enquanto sistema nocional descritivo, a gramática escolar esconde intuições interessantes sobre a linguagem sob uma capa de definições e um conjunto de critérios que não dão conta dos fatos das línguas naturais;

- enquanto prática escolar, o ensino gramatical se reduz ao exercício de técnicas insatisfatórias de descoberta e de classificação de segmentos de orações;

- em nenhum dos casos se busca responder à questão relevante para qualquer estudo gramatical da linguagem: por que as expressões significam aquilo que significam? (grifos do autor)

Tendo em vista encontrar quais seriam os problemas metodológicos fundamentais para o fracasso do ensino de gramática tal como é feito hoje nas escolas, Perini (2005, p. 49) aponta para três questões centrais: “[...] primeiro, seus objetivos estão mal colocados; segundo, a metodologia adotada é seriamente inadequada; e, terceiro, a própria matéria carece de organização lógica." (grifo nosso).

Com relação aos objetivos, Perini (2005, p. 49) identifica como erro a suposição de que “[...] o estudo da gramática é um dos instrumentos que levarão o aluno a ler e escrever melhor, [...]" pois "[...] a gente aprende a escrever escrevendo, lendo, relendo e reescrevendo; foi assim que o Veríssimo chegou lá.” (PERINI, 2005, p. 55) .

Nesse mesmo sentido, Carlos Franchi (1991, p. 24) comenta a problemática de se ensinar metalinguagem a um aluno que ainda não tem domínio lingüístico efetivo sobre seu idioma:

Exercícios gramaticais, quase todos se situam ao nível da metalinguagem, ou seja, o de adquirir um sistema de noções e uma linguagem representativa (na verdade, uma nomenclatura) para poder falar de certos aspectos da linguagem. [...] Esquece-se que a pertinência de um elemento verbal a esta ou àquela classe supõe operações efetivas (lingüísticas) do sujeito e que a própria elaboração de um sistema descritivo supõe uma familiaridade prévia com os processos envolvidos nessa construção.

Com relação à metodologia, Perini $(2005$, p. 25) ressalta a situação inconveniente em que os professores de Língua Portuguesa se encontram toda vez que precisam justificar um fenômeno da língua e são obrigados a dizer simplesmente que "é assim porque é assim", simplesmente porque a língua é um fato e não há como argumentar o porquê de ser de um jeito e não de outro. Essa atitude metodológica inspira pouco interesse nos alunos, segundo o autor, porque insinua que o que está sendo ensinado deva ser sumariamente decorado e não compreendido. 
Quanto ao problema da organização, Perini (2005, p. 52) aponta para as incongruências entre as definições dos termos e suas aplicações e exemplos: “[...] não estou dizendo que a gramática não tem lógica. Falo da matéria que se ensina nas escolas com o nome de 'gramática'." Trata-se, pois, do problema de definições que não são suficientemente amplas para abarcar todos os fenômenos da língua a que se propõem. Frágeis, acabam por serem refutadas por exemplos extraídos dos próprios compêndios que se pretendem descrevê-las, causando incômodo, tanto para os professores - que se vêem sem argumento diante das exceções - quanto aos alunos, que percebem a fragilidade da argumentação em prol das tais definições (PERINI, 2005).

Em momento algum, porém, os textos teóricos que serviram de sustentação à este trabalho refutam a necessidade do ensino de gramática na escola. Ao contrário, defendem que a gramática seja compreendida em sua integralidade, como não sendo única (e, portanto, não apenas em seu viés normativo), e com seu espaço repensado dentro da sala de aula de Língua Portuguesa, como fica claro nessa passagem de Possenti (1996, p. 56):

Falar contra a "gramatiquice" não significa propor que a escola só seja "prática", não reflita sobre questões de língua. Seria contraditório propor esta atitude, principalmente porque se sabe que refletir sobre a língua é uma das atividades usuais dos falantes e não há razão para reprimi-la na escola. Trata-se apenas de reorganizar a discussão, de alterar prioridades (discutir os preconceitos é certamente mais importante do que fazer análise sintática - eu disse mais importante, o que significa que a análise sintática é importante, mas é menos...) [grifo do autor]

\subsection{Alternativa para o ensino e aprendizagem de Língua Portuguesa - Avaliação Diagnóstica e Formativa, Sequiência Didática e Atividades Lingüísticas e Epilingüísticas}

Os quatro conceitos centrais que fundamentam este trabalho - a Avaliação Diagnóstica e Formativa, a Seqüência Didática e as Atividades Lingüísticas e Epilingüísticas - foram propostos por Semeghini-Siqueira (1997, 2002), Schneuwly, Dolz e Noverraz (2007), e 
Semeghini-Siqueira (1977; 1997), Franchi (1991), Geraldi (1991; 2002), Travaglia (1996) e

Possenti (1996), respectivamente.

Este capítulo é dedicado à revisão teórica desses conceitos.

\title{
4.3.1. Avaliação Diagnóstica e Formativa (ADeF) - conceito
}

Analisando a problemática da avaliação no ensino e aprendizagem brasileiro, Luckesi (2002, p. 81) identifica a avaliação/verificação da aprendizagem como um dos principais fatores de exclusão escolar. O autor ressalta a importância da avaliação diagnóstica, ao afirmar que:

\begin{abstract}
Em primeiro lugar, há que partir para a perspectiva de uma avaliação diagnóstica. Com isso queremos dizer que a primeira coisa a ser feita para que a avaliação sirva à democratização do ensino, é modificar a sua utilização de classificatória para diagnóstica Ou seja, a avaliação deverá ser assumida como um instrumento de compreensão do estágio de aprendizagem em que se encontra o aluno, tendo em vista tomar decisões suficientes e satisfatórias para que possa avançar no processo de aprendizagem. [grifos do autor]
\end{abstract}

A avaliação formativa também foi objeto de estudo de Perrenoud (1998, p. 103):

É formativa toda avaliação que ajuda o aluno a aprender e a se desenvolver, ou melhor, que participa da regulação das aprendizagens e do desenvolvimento no sentido de um projeto educativo. [...] a avaliação formativa define-se por seus efeitos de regulação dos processos de aprendizagem. Dos efeitos, buscar-se-á a intervenção que os produz e, antes ainda, as observações e as representações que orientam essa intervenção.

Ao relacionar os conceitos de Avaliação Diagnóstica - realizada com o objetivo de se verificar o que o aluno já sabe - e Avaliação Formativa - isto é, processual e contínua, SemeghiniSiqueira (2006c, p. 4) propõe a Avaliação Diagnóstica e Formativa (ADeF), um instrumento de trabalho que se baseia em:

[...] textos pragmáticos escritos pelos alunos de uma classe $\mathrm{X}$, a partir dos quais será possível elaborar, conscientemente, um planejamento direcionado a alunos "reais". Essa avaliação inicial permitirá que sejam propostas atividades, sobretudo em grupos heterogêneos, para sanar as dificuldades detectadas e, outras, que propiciarão o avanço na aquisição de habilidades de uso da língua. 
Embora não atribua nome algum ao procedimento que descreve como sendo a melhor forma de se saber o que deve ser ensinado aos alunos, Possenti, (1996, p. 50) acaba por apresentar o conceito de "avaliação diagnóstica":

O que já é sabido não precisa ser ensinado. Seguindo esse princípio, os programas anuais poderiam basear-se num levantamento bem feito do conhecimento prático de leitura e escrita que os alunos já atingiram e, por comparação com o projeto da escola, uma avaliação do que ainda lhes falta aprender. Nada de consultar manuais e guias para saber o que se deve ensinar, por exemplo, numa sexta série. Nada, portanto, desses programas pré-fabricados para ir do simples ao complexo, presos a uma tradição que não se justifica a não ser por ser tradição. (grifo do autor)

Contudo, a diferença entre a ADeF e a compreensão de Possenti (1996) sobre o assunto é em termos procedimentais: para ele, a vistoria no caderno dos alunos bastaria para a determinação do conteúdo já estudado. A sugestão da realização da produção de um texto escrito por Semeghini-Siqueira (2006c) parece orientar resultados mais efetivos.

A necessidade de haver uma avaliação que leve em consideração o estágio de letramento do aluno também recebeu menção nos PCN de Língua Portuguesa dos terceiro e quarto ciclos (1998, p. 34), nos seguintes termos:

[...] as situações didáticas são organizadas em função da análise que se faz dos produtos obtidos nesse processo e do próprio processo. Essa análise permite ao professor levantar necessidades, dificuldades e facilidades dos alunos e priorizar os aspectos que serão abordados.

As vantagens da ADeF em relação à avaliação/verificação convencionais são comentadas por Semeghini-Siqueira (1997, p. 13-14): (1) “ [...] viabiliza o contado com o nível lingüístico do aluno”; (2) “ [...] propicia o desenvolvimento de estratégias para a elaboração de atividades epilingüísticas [...]”; (3) “[...] habilita o professor a interagir com seu aluno de forma mais eficaz, durante o processo de produção e reelaboração/revisão do texto [...]”; (4) “[...] possibilita a inserção da pesquisa na formação docente. $\mathrm{O}$ professor passa a refletir sobre os recursos expressivos que seus alunos já estão dominando e onde se localizam os problemas [...]” e, por último, (5) “[...] permite mudança radical no processo educativo [...]”, pois desloca o foco dos problemas para a busca de soluções bem sucedidas de ensino e aprendizagem. 
Parece, portanto, que a $\mathrm{ADeF}$ é um instrumento muito importante para que o professor detecte, desde o início do trabalho, as necessidades verdadeiras dos alunos reais que participam do processo de ensino e aprendizagem, o que torna mais fácil propor soluções plausíveis que possam adequarem-se à cada sala de aula.

\subsubsection{Seqüência Didática (SD) - conceito}

Segundo Schneuwly, Dolz e Noverraz (2007, p. 97), seqüência didática

[...] é um conjunto de atividades escolares organizadas, de maneira sistemática, em torno de um gênero textual oral ou escrito. [...] Uma sequiência didática tem, precisamente, a finalidade de ajudar o aluno a dominar melhor um gênero de texto, permitindo-lhe, assim, escrever ou falar de uma maneira mais adequada numa dada situação de comunicação. [grifo dos autores].

Essas atividades se organizam da seguinte forma:

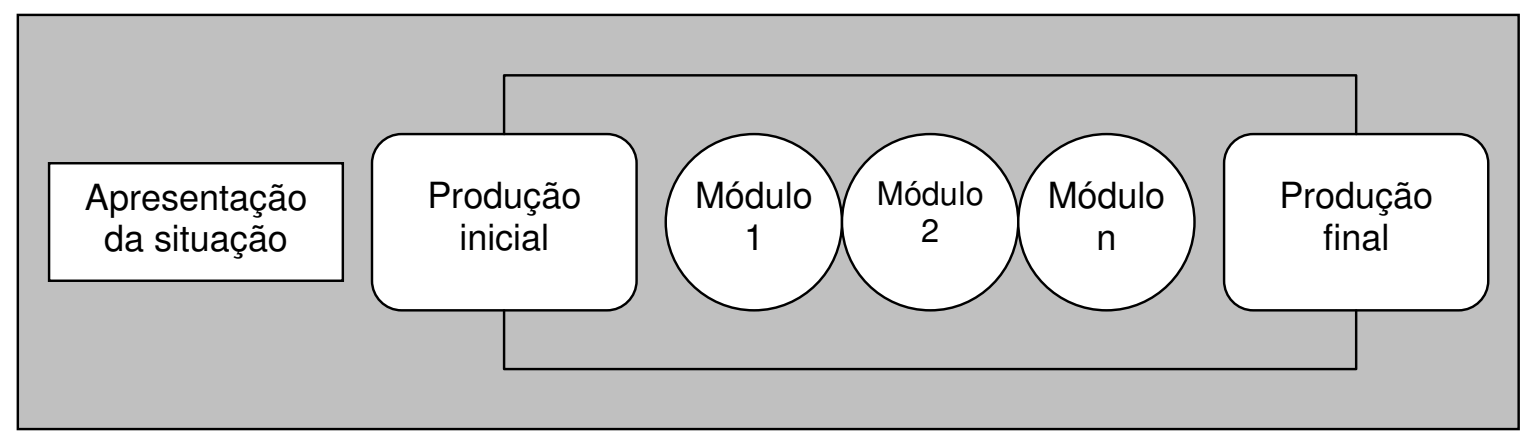

Figura 2 - Esquema da seqüência didática (SCHNEUWLY; DOLZ; NOVERRAZ, 2007, p. 98)

Iniciando com a apresentação da situação, na qual se descreve "de maneira detalhada a tarefa de expressão oral ou escrita que os alunos deverão realizar" (SCHNEUWLY; DOLZ; NOVERRAZ, 2007, p. 98), a primeira produção textual do aluno (produção inicial) tem o objetivo de permitir "[...] ao professor avaliar as capacidades já adquiridas e ajustar as atividades e os exercícios previstos na seqüência às possibilidades e dificuldades reais de uma turma. Além disso, ela define o significado de uma seqüência para o aluno, isto é, as capacidades que deve desenvolver para melhor dominar o gênero de texto em questão."

Semelhante em função à ADeF (SEMEGHINI-SIQUEIRA, 2006c, p. 4), a produção inicial, entretanto, diferencia-se sutilmente daquela pela necessidade de ser uma produção relacionada 
ao gênero que será trabalhado ao longo da seqüência didática. A ADeF, por outro lado, não precisa estar vinculada a esse gênero (ainda que isso seja desejável).

Nos módulos, além de se "[...] trabalhar os problemas que apareceram na primeira produção [...]" (SCHNEUWLY; DOLZ; NOVERRAZ, 2007, p. 103) [grifo dos autores], o aluno participa de atividades que o levarão a um domínio crescente de diversos aspectos relacionados ao gênero. Serão nesses momentos em que questões como a elaboração do conteúdo, o planejamento e a realização do texto, as atividades e exercícios necessários para que tanto forma quanto conteúdo dos textos em trabalho sejam refinados.

Além dos próprios textos, durante os módulos, o aluno elabora listas nas quais registra as aquisições feitas durante o processo de escrita e re-escrita textual. Essa atividade guarda semelhanças àquelas realizadas no ensino de língua estrangeira conhecida pelo nome de accountability, cujo propósito, similarmente, é o de registro e a percepção consciente da aprendizagem.

Encerra o ciclo a produção final, momento no qual " $[\ldots]$ o aluno pode pôr em prática os conhecimentos adquiridos e, com o professor, medir os progressos alcançados. A produção final serve também, para uma avaliação de tipo somativo, que incidirá sobre os aspectos trabalhados durante a seqüência.” (SCHNEUWLY; DOLZ; NOVERRAZ, 2007, p. 98). Essa avaliação, ainda que implique nota, também é um instrumento que possibilita ao professor planejar melhores estratégias que viabilizem melhores resultados futuros.

\subsubsection{Atividades lingüísticas (ALs), epilingüísticas (AEs) e metalingüísticas (AMs) - conceitos}

Segundo Semeghini-Siqueira (1997, p. 7), “[...] as atividades lingüísticas são os usos da língua tanto na modalidade oral como escrita: o falar, o ler e o escrever. Abrangem as práticas de leitura e as práticas de produção de texto, entre outras.” [grifo da autora]. Franchi (1991, p. 35) acrescenta a essa definição o papel específico da escola:

A atividade lingüística é nada mais do que o exercício pleno, circunstanciado, intencionado e com intenções significativas da própria linguagem. Ela já se dá, obviamente, nas circunstâncias cotidianas da comunicação no âmbito da família e da comunidade de nossos alunos. E somente pode reproduzir-se, na escola, se esta se tornar um espaço de rica 
interação social que, mais do que mera simulação de ambientes de comunicação, pressuponha o diálogo [...].

A relação entre atividade lingüística e estratégias discursivas é enfocada pela definição de Travaglia (1996, p. 33):

\begin{abstract}
As atividades lingüísticas são aquelas que o usuário da língua (falante, escritor/ ouvinte, leitor) faz ao buscar estabelecer uma interação comunicativa por meio da língua e que lhe permite ir construindo o seu texto de modo adequado à situação, aos seus objetivos comunicacionais, ao desenvolvimento do tópico discursivo, que alguns chamam de assunto ou tema. Neste caso, o falante faz uma reflexão sobre a língua que se diria automática, porque ele seleciona recursos lingüísticos e os arranja em um trabalho de construção textual em que lança mão dos mecanismos lingüísticos que domina sem um trabalho de explicação dos mesmos. As atividades lingüísticas são, pois, as atividades de construção e/ou reconstrução do texto que o usuário realiza para se comunicar.
\end{abstract}

Já, o conceito de atividade epilingüística, ainda que não referido dessa maneira, mas como "gramática não-consciente", encontra-se na literatura da área de Educação desde a década de 70, por meio dos Subsídios para a implantação do Guia Curricular de Língua Portuguesa - $3^{\mathrm{a}}$. e $4^{\mathrm{a}}$. séries (1977, p. 149), publicados pela CENP/SEE-SP. Naquele documento, cujo trabalho foi coordenado por Semeghini-Siqueira já se conjecturava acerca do ensino de metalinguagem, suspeitando não sê-lo a melhor maneira de se levar o aluno à leitura e à escrita: "Se o objetivo do ensino de Língua portuguesa, nestas séries [ $3^{\mathrm{a}}$. e $4^{\mathrm{a}}$.], é desenvolver a comunicação oral e escrita, será que o fato de 'aprender' teoria gramatical ajudará a criança a manejar melhor sua língua?"

Ainda que muitas vezes não esteja explícita a expressão "atividade epilingüística", essa proposta de prática educativa aparece descrita em diferentes momentos da literatura acadêmica, por meio de diversos teóricos, como em Carlos Franchi (1991, p. 36-37):

Chamamos de atividade epilingüística a essa prática que opera sobre a própria linguagem, compara as expressões, transforma-as, experimenta novos modos de construção canônicos ou não, brinca-se com a linguagem, investe as formas lingüísticas de novas significações. Não se pode ainda falar de "gramática" no sentido de um sistema de noções descritivas, nem de uma metalinguagem representativa como uma nomenclatura gramatical. Não se dão nomes aos bois nem aos boiadeiros.

Em Semeghini-Siqueira (1998, p. 4), encontra-se ainda: 
GRAMÁTICA 2 será o conjunto de estratégias, concernentes às atividades epilingüísticas. Elas requerem uma reflexão sobre a linguagem, ou melhor, sobre as diferentes formas de dizer. Nesta prática, as expressões são comparadas, transformadas, "brinca-se com a linguagem". É um trabalho consciente. Trata-se de uma atividade que toma a própria linguagem como objeto de operações transformadoras.

Geraldi (2002, p. 63-64) chama à atenção para o fato de que:

Todas essas considerações mostram a necessidade de transformar a sala de aula em um tempo de reflexão sobre o já-conhecido para aprender o desconhecido e produzir o novo. É por isso que atividades de reflexão sobre a linguagem (atividades epilingüísticas) são mais fundamentais do que aplicação a fenômenos sequer compreendidos de uma metalinguagem de análise construída pela reflexão de outros. Aquele que aprendeu a refletir sobre a linguagem é capaz de compreender uma gramática - que nada mais é do que o resultado de uma (longa) reflexão sobre a língua; aquele que nunca refletiu sobre a linguagem pode decorar uma gramática, mas jamais compreenderá seu sentido. [grifo do autor]

Travaglia (1996, p. 34) faz a seguinte consideração:

As atividades epilingüísticas são aquelas que suspendem o desenvolvimento do tópico discursivo (ou do tema ou do assunto), para, no curso da interação comunicativa, tratar dos próprios recursos lingüísticos que estão sendo utilizados, ou de aspectos da interação. Segundo Geraldi (1993, p. 24-25) elas estão presentes nas hesitações, correções (auto ou heteroiniciadas), pausas longas, repetições, antecipações, lapsos, etc. ou, por exemplo, quando um interlocutor questiona a atuação interativa de outrem (se ele fala, se fala demais) ou controla a tomada da palavra numa conversação, indicando quem deve ou não falar por recursos diversos [...].

A atividade epilingüística pode ser ou não consciente. Se pensamos que inconsciente se relaciona com a gramática de uso, se consciente parece se aproximar mais da gramática reflexiva, todavia, de qualquer forma há uma reflexão sobre os elementos da língua e de seu uso relacionada ao processo de interação comunicativa.

Por fim, há uma menção nos PCN de Língua Portuguesa dos terceiro e quarto ciclos (1998, p.28), ainda que em nota de rodapé:

Por atividade epilingüística se entendem processos e operações que o sujeito faz sobre a própria linguagem (em uma complexa relação de exterioridade e interioridade). A atividade epilingüística está fortemente inserida no processo mesmo da aquisição e desenvolvimento da linguagem.

Em linhas gerais, portanto, as atividades epilingüísticas se caracterizam por serem operações mais conscientes concernentes ao uso a língua, cujo principal finalidade é levar o aprendiz a 
diferentes formas de dizer (e escrever) a mesma coisa, o que implica uma reflexão sobre a linguagem em si. Porém, essa reflexão não se dá em função de classificações ou categorizações como ocorre nas atividades metalingüísticas, nas quais "[...] o objetivo é aprender a categorização dos elementos da língua, por exemplo: substantivo, adjetivo, verbo, sujeito/predicado etc. (SEMEGHINI-SIQUEIRA, 1997, p. 7).

Todos os autores referidos acima postulam, em linhas gerais, que o trabalho com atividades epilingüísticas deva ser privilegiado em relação àquele com atividades metalingüísticas; tanto em termos de tempo dispensado em sala de aula quanto com relação à ordem de trabalho, preconizando a sua antecedência em relação a qualquer abordagem metalingüística.

Não cabe aqui, porém, a reflexão dos porquês tais atividades não integrarem ainda hoje regularmente as práticas de sala de aula. Esta proposta, porém, basear-se-á prioritariamente na utilização de atividades lingüísticas e epilingüísticas, em detrimento do uso das atividades metalingüísticas, com resultados bastante favoráveis, descritos no capítulo 6 . 
ENTRADA EM CAMPO: IN LOCO , COMO TUDO ISSO ACONTECE DE FATO? 


\section{ENTRADA EM CAMPO: IN LOCO, COMO TUDO ISSO ACONTECE DE}

\section{FATO?}

Bem, há apenas duas matérias que querem REALMENTE que suas crianças sejam ensinadas: caligrafia e aritmética. Caligrafia, principalmente. [...] Muitas cópias bonitas e bem feitas que as garotas possam levar para casa, e seus pais mostrarem aos vizinhos e nos fazerem um pouco de propaganda gratuita. ${ }^{81}$

George Orwell ${ }^{82}$

Neste capítulo, apresenta-se a análise das observações realizadas por meio de pesquisa de campo de cunho etnográfico interpretativo ocorrida ao longo de dois meses em uma escola particular de São Paulo. As disciplinas cujas aulas foram acompanhadas uma vez por semana foram Língua Portuguesa e Língua Inglesa (extracurricular).

O foco da observação foi dirigido ao trabalho com atividades lúdicas realizado por ambas as professoras. Procurou-se notar tanto como tais atividades se relacionavam com o conteúdo ministrado nas disciplinas, quanto a forma pela qual estavam inseridas no contexto da sala de aula. Os papéis das professoras e dos alunos durante essas atividades também constituiu objeto de atenção.

Por fim, procurou-se traçar considerações acerca da possibilidade de aproveitamento de algumas estratégias bem sucedidas de utilização de atividades lúdicas do contexto da aula de Língua Inglesa à proposta de ensino e aprendizagem de Língua Portuguesa que orientou a Segunda Entrada em Campo desta pesquisa.

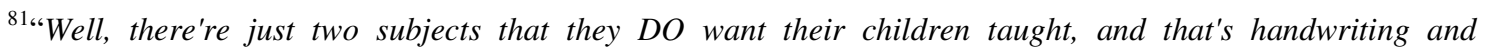
arithmetic. Especially handwriting. [...] Plenty of nice neat copies that the girls can take home, and that the parents'll show off to the neighbours and give us a bit of a free advert." (tradução nossa)

${ }^{82}$ ORWELL, G. Clergyman's daughter. Disponível em: <http://gutenberg.net.au/ebooks02/0200011.txt> Último acesso em: 1/12/2006.
} 


\subsection{Na aula de Inglês}

Com o intuito de preservar a identidade da professora do curso extracurricular de Inglês, foilhe atribuído o nome fictício Ingrid. Trabalhando há 9 anos e meio no curso de idiomas que alocava as dependências da escola particular, onde ocorreu a Entrada em Campo para a realização desta pesquisa de cunho etnográfico investigativo, esse era o primeiro semestre de Ingrid ministrando aulas de inglês extracurricular naquele estabelecimento de ensino. A frente de uma sala com 16 alunos (9 meninos e 7 meninas, que freqüentavam paralelamente o Ensino Fundamental II, sendo que apenas 5 não estudavam nem mesma sala nem no mesmo ano no ensino regular ${ }^{83}$ ), a professora de Inglês se dizia "cansada e desmotivada" com seu trabalho na escola de idiomas, pois se julgava "muito pressionada pela direção", mas dizia gostar bastante da experiência de ir até outra escola, pois se sentia "mais livre para dar aula".

Como Ingrid e a pesquisadora eram colegas de trabalho (ambas professoras do curso de idiomas), a permissão para o acompanhamento de suas aulas na escola particular foi facilmente concedida e o constrangimento das primeiras aulas cedeu aos poucos à parceria. Assim, ao final de cada dia de observação, as duas professoras se reuniam para comentar detalhes a respeito da escolha de procedimentos e sobre situações que haviam ocorrido durante a aula.

Os alunos do curso extracurricular de inglês da professora Ingrid também foram bastante acessíveis, na medida em que concordaram em diversos momentos a ficarem após o término de suas aulas conversando com a pesquisadora. De um modo geral, eles se mostravam contentes com a aula de Ingrid, que qualificavam como muito diferentes das da escola, “porque eram bem divertidas". Não gostavam, porém, do fato de serem muito longas e logo após o almoço.

A escola particular onde as aulas ocorreram não apresentou nenhuma objeção para que as observações das aulas de Inglês extracurricular ocorressem, o que não se repetiu nas de Português, como será comentado adiante neste capítulo.

\footnotetext{
${ }^{83} \mathrm{E}$, portanto, esses 5 alunos não fizeram parte dos sujeitos concernentes à pesquisa.
} 
Todas as atividades de sala de aula foram conduzidas preferencialmente em inglês pela professora, que se utilizava do português apenas quando os alunos realmente não conseguiam compreendê-la ou quando fazia comentários paralelos, não relacionados diretamente ao conteúdo proposto para o ensino. Os alunos, por outro lado, ainda que encorajados pela professora para utilizarem a língua alvo durante o maior tempo possível, conversavam muito em português, assuntos relativos ou não à aula.

O estágio em que esses alunos estavam era o básico (básico 2), o que significa que já haviam sido expostos a: se apresentar, fazer pedidos, falar sobre suas atividades - tanto rotineiras quanto momentâneas, dar/seguir instruções simples como orientações de local onde estão objetos ou endereços, e aprenderam vocabulário básico relacionado a roupas, comida, tarefas comuns a estudantes e cômodos da casa. Todas essas situações encontravam-se articuladas em torno do ensino do tempo verbal "presente", nas modalidades "simples" e "contínua" (Simple Present / Present Continuous), dividido em três Unidades de Trabalho: uma sobre previsão do tempo, outra sobre planos para uma viagem e a última, sobre planos para o futuro.

As aulas iniciavam-se às 13:30 e terminavam às 15:20, com 10 minutos de intervalo, ocorrendo apenas às terças-feiras. O módulo foi composto por 32 aulas de 50 minutos cada, perfazendo um total de 27 horas de curso, das quais aproximadamente 16 horas foram acompanhadas pela pesquisadora.

\subsubsection{O método adaptado pela instituição}

Partindo da perspectiva teórica da Abordagem Comunicativa, a instituição de ensino de idiomas que presta serviços à escola regular escolhida para ser o local desta pesquisa utilizase de algumas adaptações das práticas preconizadas por essa linha de estudos a suas necessidades, mantendo, porém, a seqüência do PPP $^{84}$ como eixo orientador das atividades realizadas em sala de aula. Dentre as principais adaptações está a transformação da etapa de PRODUÇÃo (production) em TAREFA FINAL (FINAL TASK). Essa mudança foi incorporada ao método praticado pela escola depois de experimentalismos com o Task-based Language Teaching na década de 90.

\footnotetext{
${ }^{84}$ Presentation, Practice, Production, comentados no capítulo 3.3.
} 
O material didático adotado é importado e específico para adolescentes. Embora as situações retratadas nos dois livros que o compõem, um de sala de aula e outro de lição de casa, sejam pertinentes ao universo jovem, como em todo material importado, há certo descompasso entre a realidade ali expressa e a realidade brasileira. Isso ocorre, em especial, quando há personagens em situações cotidianas nos diálogos-modelos da introdução de cada capítulo.

Ainda que boa parte da aula esteja baseada nos textos do livro de classe (Student's book), a sua utilização não segue uma seqüência linear. O conteúdo do livro texto, portanto, é trabalhado segundo um esquema dividido em quatro etapas diferentes: (1) ENGAJAMENTO (Engagement), (2) EXPOSIÇÃO/PERCEPÇÃO/ANÁLISE (Exposure/ Noticing /Analysis), (3) Prática (Practice) e (4) TAREFA Final (FINAL TASK). Esses quatro momentos da lição compõem uma Unidade de Trabalho (Unit of work), cujo eixo orientador está centrado em tópicos gramaticais (GRAMÁTICA 3), contextualizados em situações pertinentes ao universo da faixa etária a qual o curso se propõe.

No ENGAJAMENTO, o professor introduz o tópico que será discutido ao longo da Unidade de Trabalho, procurando relacioná-lo à experiência de vida dos alunos. Geralmente ocorre uma conversa inicial entre professor e o grupo todo, em inglês, na medida do possível.

Em seguida, os alunos ouvem uma gravação de um diálogo ou lêem um texto relacionado ao assunto que fora discutido anteriormente. É a partir desse modelo, contido na EXPOSIÇÃO, que será feito todo o trabalho de PERCEPÇÃo e da ANÁLISE. Nesse curso de idiomas, essas etapas se referem geralmente à GRAMÁTICA 3 (atividades com metalinguagem). Assim, durante a PERCEPÇÃo, o aluno é levado a identificar e isolar a estrutura a ser estudada enquanto na ANÁLISE, há a explicação sobre como a estrutura funciona. Sucedem-se, então, diversos exercícios de PRÁTICA, realizados com o intuito de fixação da estrutura. Pelo método, a maioria das atividades lúdicas sugeridas no próprio manual do professor se concentra nessa etapa.

Por último, é apresentada uma situação em que o aluno deve se utilizar (mas não somente) da estrutura recém aprendida para interagir com seus colegas em uma situação semelhante àquela 
apresentada na EXPOSIÇÃO. Trata-se da TAREFA FINAL de cada Unidade de Trabalho. Pelo seu caráter de simulação ${ }^{85}$, essa atividade possui um forte componente lúdico em sua essência.

Evidentemente, não é possível realizar todas essas etapas em uma só aula, variando, de acordo com o grau de dificuldade do tópico abordado, o número de aulas atribuídas a cada Unidade de Trabalho ${ }^{86}$. Por isso, o professor deve começar e terminar toda aula de maneira que o aluno relembre o que foi estudado na aula anterior. Geralmente esse tipo de exercício demora poucos minutos e se assemelha aos exercícios de ENGAJAMENTO do início da Unidade de Trabalho. Muitas dessas atividades são jogos, como "forca", "jogo da velha", "memória", entre outros. De modo semelhante, nos minutos finais da aula, o professor recorda os alunos sobre o que foi aprendido naquele dia - são os exercícios de CONTABILIDADE (Accountability).

Todo o livro adotado por essa escola possui um roteiro bastante minucioso, contendo o que deve ser feito nessas quatro etapas para todas as Unidade de Trabalho. Embora os professores não sejam obrigados a segui-lo (e, geralmente não o fazem na sua totalidade) há certa cooptação por parte da direção acadêmica para que não só a seqüência das Unidades de Trabalho seja respeitada, mas também os materiais por elas sugeridos sejam utilizados. Na prática, como a maioria dos professores possui, em média, entre 8 a 10 turmas, é muito comum que eles simplesmente sigam o que o roteiro "sugere".

\subsubsection{Do método à prática concreta: observações das aulas de Inglês}

Nas 16 aulas $^{87}$ em que a pesquisadora esteve presente, Ingrid variou apenas 7 das 35 atividades realizadas, perfazendo um total de apenas $20 \%$ de atividades cuja proposta (ou procedimento) não constava no manual do professor. Isso revela o poder daquele instrumento sobre a decisão da professora em sala de aula. Quando questionada sobre o assunto, disse que o fazia por falta de tempo para procurar outra fonte de consulta, além do que já havia dado aquela aula muitas vezes e sabia que aquele procedimento "daria certo". A principal implicação dessa conduta por parte de Ingrid está no fato de que muitas das atividades realizadas em sua aula não correspondiam exatamente às necessidades reais de seus alunos. Um exemplo disso foi observado em uma aula em que a professora explicava o uso de um

\footnotetext{
${ }^{85}$ A definição de simulação encontra-se no capítulo 2.3 .

${ }^{86} \mathrm{Em}$ média, porém, são utilizadas 6 aulas de 50 minutos por Unidade de Trabalho.

${ }^{87} \mathrm{Em}$ cada dia ocorriam 2 aulas de 50 minutos.
} 
determinado tempo verbal (Present Continuous) enquanto boa parte dos alunos conversava e trocava, por debaixo das carteiras, revistas em quadrinhos. Depois da aula, a pesquisadora questionou alguns deles sobre o porquê de tal atitude ao que responderam que já haviam estudado aquela matéria nas aulas regulares de Inglês. Nas aulas subseqüentes, notou-se que, de fato, esses alunos não apresentavam dificuldade alguma para executarem os exercícios metalingüísticos propostos. Porém, não eram capazes de se expressar oralmente, revelando a necessidade de prática e não de exercícios de metalinguagem.

Conseqüentemente, o desencontro de necessidades (das presumidas - e programadas - pela professora e as reais, advindas dos alunos reais que freqüentavam aquelas aulas) pareceu ser uma das principais causas dos momentos de indisciplina e de apatia observados, dado que ocorreram principalmente durante atividades que não (ou quase não) propunham desafio algum àqueles alunos. Por outro lado, nos momentos em que havia oportunidade de participação efetiva, quer fosse pela comunicação de uma experiência vivida/história que sabiam, quer fosse pelo engajamento em alguma atividade lúdica, os alunos demonstravam grande motivação em realizarem aquilo que lhes havia sido proposto pela professora. Isso pôde ser observado especialmente durante uma TAREFA que envolveu a elaboração de um folheto de viagem, seguida por um role play ${ }^{88}$ (em que a sala se dividia em dois grupos: o dos agentes de viagem e o dos turistas em busca do melhor pacote de viagens) ${ }^{89}$. Outro ponto que pareceu influenciar positivamente no andamento das aulas observadas foi a variedade das atividades realizadas, como se pode notar na figura 3.

Pela divisão do conteúdo em etapas dentro das Unidades de Trabalho, o método adotado por essa escola propicia que diversos tipos de atividades sejam realizados durante a aula, com propósitos diferentes, mobilizando conhecimentos distintos. Decorre disso mais dinamismo na aula e a maior participação dos alunos.

Outra conseqüência desejável é que a GRAMÁTICA 3 (atividades metalingüísticas) deixa de ocupar a quase totalidade do tempo da aula, como foi observado por Neves (2003) e Semeghini-Siqueira $(1998,2006 a)^{90}$ em aulas de Português, para dividir espaço com atividades lingüísticas (GRAMÁTICA 1) e epilingüísticas (GRAMÁTICA 2), como é preconizado

\footnotetext{
${ }^{88}$ Definido no capítulo 2.3 .

${ }^{89}$ Essa atividade encontra-se descrita em maiores detalhes na próxima seção do capítulo.

${ }^{90}$ E corroborada pela observação de aula de Língua Portuguesa realizada neste trabalho.
} 
por Eglê Franchi (1984), Carlos Franchi (1991), Geraldi (1985, 1991, 2002), Travaglia (1996), Possenti (1996), Perini (2005) e Semeghini-Siqueira (1997, 1998, 2001, 2005, 2006a, 2006b, 2006c).

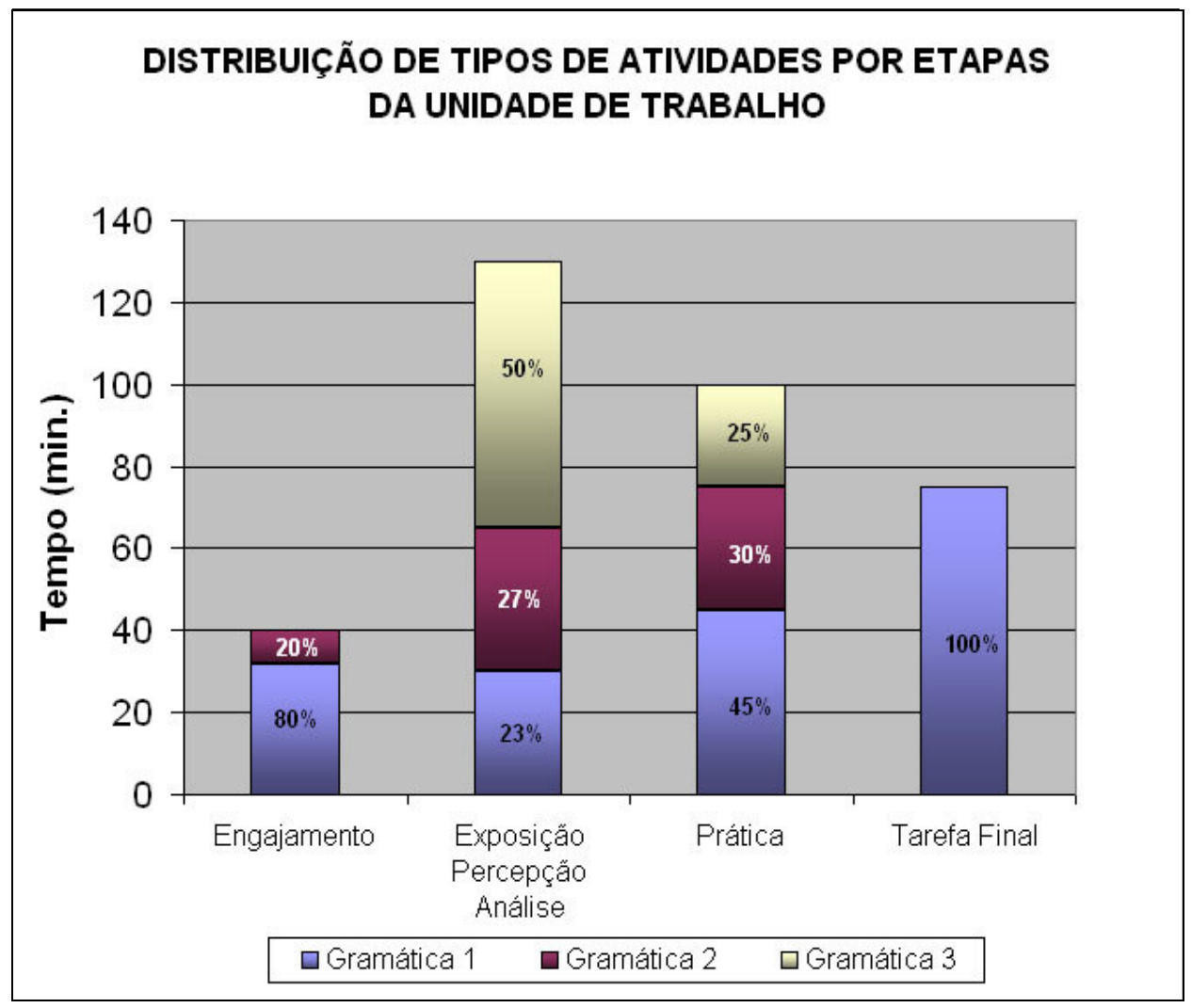

Figura 3 - Distribuição de tipos de atividades por etapas da Unidade de Trabalho

\subsubsection{E os jogos? Como eram na aula de inglês?}

Vários jogos tomaram parte das aulas de Inglês observadas, com um resultado imediato, de modo geral, positivo, pois “acordavam os alunos". Essa era, inclusive, a justificativa de Ingrid para recorrer a eles com certa frequiência. Ainda assim, não era por vontade da própria professora que tais jogos ocorriam, mas pela indicação do manual do professor, que definia qual, como e quando tais atividades deveriam ser realizadas. Talvez por esse motivo, notouse que o padrão de ocorrência de tais atividades era muito semelhante nas três Unidades de Trabalho acompanhadas pela pesquisadora (figura 4).

Durante o ENGAJAMENTO, sempre havia um momento para conversas, e outro, para jogos. Os jogos dessa etapa eram rápidos e buscavam ou relembrar o conteúdo da aula anterior ou trazer 
à discussão o tema central a ser enfocado na aula em questão. Eram comuns atividades lúdicas como Palavra Cruzada na lousa, Jogo da Velha, Spidergram (um tipo de diagrama em forma de aranha), de onde saíam palavras relacionadas ao tópico principal da aula. Simulações também foram observadas, sendo que o contexto proposto para essa atividade era semelhante àqueles abordados na etapa de PERCEPÇÃO.

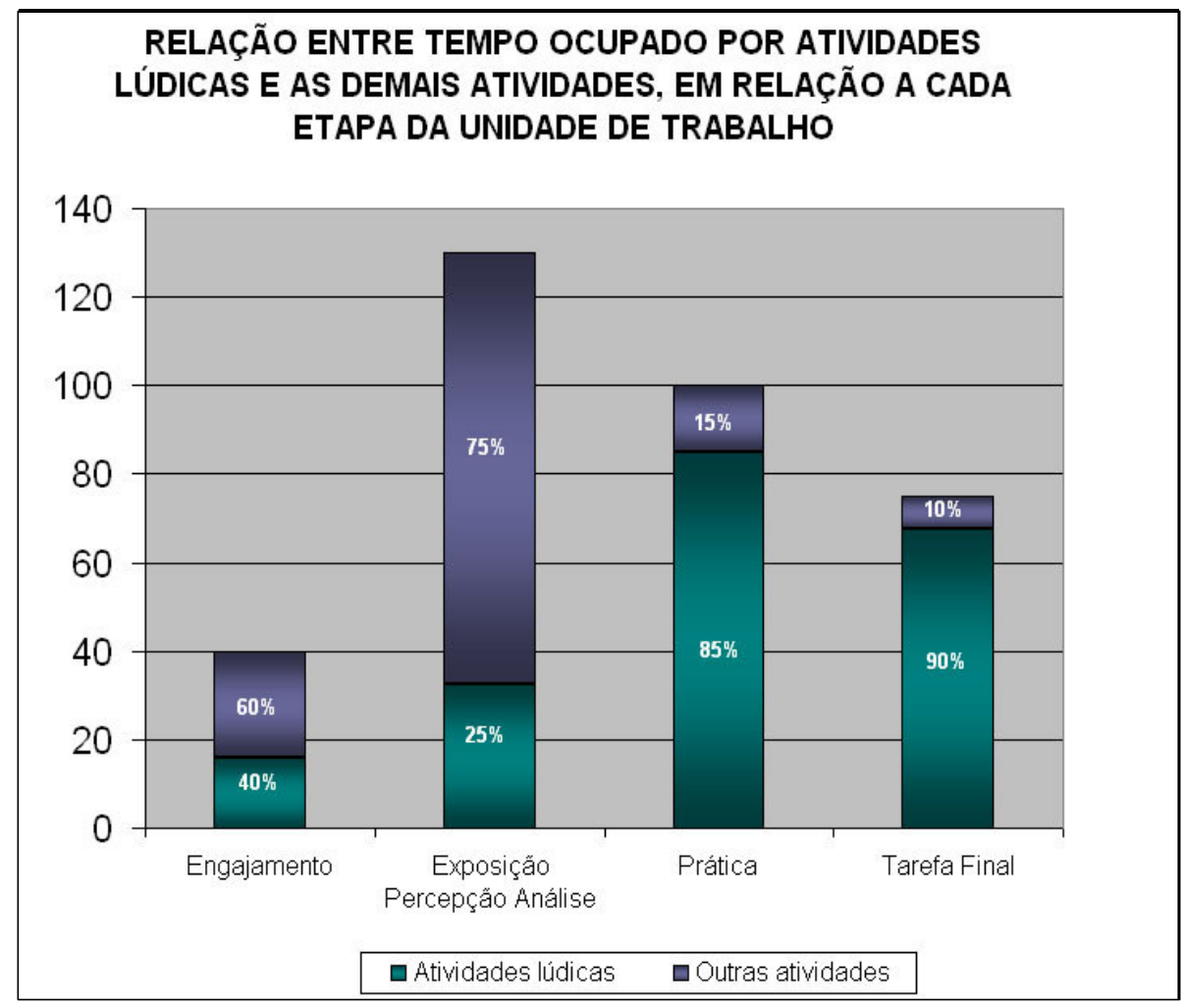

Figura 4 - Relação entre tempo ocupado por atividades lúdicas e as demais atividades, em relação a cada etapa da aula

Na EXPOSIÇão, a leitura performática dos diálogos garantia pelo menos 15 minutos de roleplay $^{91}$. A professora escolhia dois ou três dos muitos voluntários para lerem os diálogos da gravação recém ouvida. Mesmo que o propósito primeiro dessa atividade não contemplasse o lúdico, pois se trata apenas da leitura para o esclarecimento de dúvidas de vocabulário e da pronúncia de palavras mais complicadas, os próprios alunos tornaram a atividade em uma simulação, ao interpretarem as personagens, fazendo vozes e trejeitos. Como havia continuidade entre as histórias que iniciam cada unidade do livro, os alunos agiam como se estivessem em uma rádio-novela, e procuravam ler (e representar) de uma maneira muito divertida.

\footnotetext{
${ }^{91} \mathrm{~A}$ definição de role-play encontra-se no capítulo 2.3. Em linhas gerais, trata-se de uma simulação mais estereotipada, cujas personagens podem ser facilmente identificadas com seus papéis sociais.
} 
Poucas atividades lúdicas ocorrem na PERCEPÇão. A mais comumente observada baseava-se em brincadeiras do tipo "encontre alguém que...", cujo propósito era levar o aluno a perceber o padrão lingüístico que seria explicitado no passo seguinte, ou seja, na ANÁLISE. Nesse outro momento da lição, não se observou ocorrência de jogos, talvez porque o trabalho estivesse centrado na explicação gramatical (GRAMÁTICA 3) e no professor.

Na etapa seguinte, da PRÁTICA, havia três tipos de atividades lúdicas distintas que eram realizadas. A primeira delas "mascarava" um exercício metalingüístico, quer fosse por meio de cartas que continham frases para serem completadas, ou pela repetição/ recombinação de termos ou palavras em frases. Essas atividades apontavam todas para o mesmo objetivo: a internalização do conteúdo explicitado durante a ANÁLISE. O segundo tipo envolvia alguma troca de informação entre os alunos, por meio de exercícios em que um precisava fazer uma pergunta ao outro para solucionar algum problema proposto pela professora ou pelo livro. $\mathrm{O}$ terceiro tipo nem sempre ocorria, sendo suprimido algumas vezes quando a professora estava atrasada com o cronograma, o que representou um grande prejuízo para os alunos porque esses exercícios funcionariam como um elo entre a prática controlada, realizada até então, e a produção mais livre, presente na TAREFA FINAL. A única atividade, porém, observada possuía caráter lúdico, pois se tratava de uma brincadeira de "detetive". Em grupos de 5 alunos, um aluno se fazia de detetive enquanto os outros recebiam cartõezinhos com informações sobre suas personagens, todos suspeitos. Por meio de perguntas semelhantes àquelas até então praticadas, o aluno "detetive" tinha que descobrir quem era o culpado entre os colegas "suspeitos".

Na última fase, a da TAREFA FINAL, pelo seu próprio caráter de simulação, praticamente todas as atividades conduzidas poderiam ser consideradas lúdica em algum sentido. Optou-se, porém, por considerar as interações que levavam em conta informações/opiniões verdadeiras dos alunos como atividade não-lúdica, pois não se tratavam de simulação e sim, de debate.

Um bom exemplo da utilização de uma atividade lúdica enquanto TAREFA FINAL foi a elaboração de um folheto de viagem, cuja inspiração, segundo a professora, veio de uma atividade realizada em um curso promovido pela escola em que trabalhava naquele momento. 
A professora iniciou o tema perguntando, em inglês, "Se vocês pudessem escolher um lugar para viajar agora, para onde vocês iriam?" Assim, desde o início da atividade, ela incluiu um elemento de imaginação, que foi sendo alimentado até o seu término, na aula seguinte. Depois de ouvir uma boa parte dos alunos, ela sugeriu "O que vocês acham de ir para Sydney, na Austrália?" Justificou a escolha dizendo que ela própria queria ir para lá. Na verdade, era uma forma de introduzir o texto do livro que eles teriam que ler, para depois usarem de modelo para suas próprias produções.

$\mathrm{Na}$ aula seguinte, sob a orientação que doravante seriam donos de uma agência de turismo e teriam de escolher qual lugar era mais interessante para montar um pacote e um folheto promocional, os alunos começaram seu trabalho de elaboração do texto.

Todos participaram ativamente da escolha, da elaboração do texto, do desenho do material e da sua pintura. Quando o texto estava pronto e decorado o folheto de viagens, a professora dividiu a sala em duas equipes, uma de turistas e outra, de vendedores de agência de turismo. A participação na atividade foi impressionante.

Os procedimentos de briefing e debriefing ${ }^{92}$ integraram todas as atividades lúdicas propostas pela professora durante as aulas observadas, o que facilitou não apenas a agilidade na realização desses jogos, mas também, sua integração com as demais atividades ocorridas durante a aula. Portanto, na aula de Língua Inglesa, o lúdico desempenhava um papel extremamente importante: era a ponte entre a realidade - tanto entendida como sendo as experiências já vividas por essas crianças, quanto aquelas que um dia vivenciarão fora da escola - e a sala de aula.

\subsection{Na aula de Português}

Antes que qualquer consideração seja feita acerca das aulas de Língua Portuguesa, dado o fato de se tratar de um relato de cunho etnográfico investigativo, faz-se necessário que uma

\footnotetext{
${ }^{92}$ Tratados na seção 2.3 deste texto. Em resumo, o briefing se constitui em um procedimento que introduz e contextualiza o jogo, enquanto o debriefing é o encerramento da atividade, no qual a aprendizagem advinda do jogo é explicitamente comentada.
} 
circunstância prévia à Entrada em Campo, mas bastante reveladora sobre a realidade que a pesquisadora iria encontrar, seja brevemente relatada.

Ao contrário das aulas de Língua Inglesa, em que não houve objeção por parte da escola regular pesquisada em permitir que as observações de aula ocorressem - até porque a própria pesquisadora também lecionava no estabelecimento de ensino em questão, por meio do curso de inglês extracurricular que prestava serviços dentro das dependências dessa escola nos horários em que os alunos do período integral não tinham aulas regulares - foi bastante difícil conseguir autorização da parte da diretoria para a realização da pesquisa nas aulas de Língua Portuguesa. O motivo justificado foi que a pesquisadora não era ex-aluna, e apenas ex-alunos tinham acesso a estágios no colégio. O impasse teve de ser resolvido diretamente entre a direção do curso de inglês (do qual a pesquisadora era funcionária) e do colégio pesquisado.

Essa experiência anterior à Entrada em Campo apontou para uma realidade que acabou sendo confirmada ao longo do período de observação da pesquisa: o status da aula de Inglês extracurricular era bastante diferente daquele atribuído às aulas regulares: tratava-se de um curso "paralelo", de "menor importância". Por esse motivo, não só a direção, mas também os próprios alunos permitiam algumas "facilidades" para com ele, não aceitas no curso regular.

Da parte da direção, essa diferença era percebida no pequeno vínculo que a escola estabelecia com o curso que era ministrado em suas dependências. Exemplo disso foi a negligência com que a direção agiu em relação à disponibilização de salas de aula para a realização de aulas que excediam a quantidade programada no início do semestre, em virtude dos cancelamentos ocorridos por causa dos jogos do Brasil na copa do mundo.

Por parte dos alunos, havia dois tipos de opinião geral a respeito daquele curso: pareciam mais dispostos a colaborar com a professora - porque a aula era mais "legal" e tinha "joguinho", mas não levavam muito a sério as atividades que precisavam fazer, especialmente em casa, porque, "eu não vou repetir nisso, vou?", como um dos alunos respondeu à pesquisadora quando questionado sobre o porquê de não fazerem a lição de casa para o curso extracurricular de Inglês.

Por outro lado, as aulas de Português eram um dos pilares do ensino da escola e, portanto, o zelo com relação a qualquer espécie de "interferência" na aula. Certamente, por esse motivo, 
pesava sobre a professora de Português a responsabilidade de representar aquilo que de mais tradicional a escola tinha a oferecer. Não por acaso, uma aula antes da pesquisadora começar as suas observações na $6^{\mathrm{a}}$ série $\mathrm{B}$, a coordenadora geral dos cursos do Fundamental II visitou a sala e avisou a todos que deveriam se comportar, porque teriam "visita"93.

Marta, nome fictício atribuído à professora de Português, iniciava todas as suas aulas da mesma forma: escrevendo "Bom dia" na lousa. Dos 19 alunos ${ }^{94}$ da sala de aula da 6 a série em que lecionava, apenas uns 4 ou 5 sempre respondiam. Os demais, conversavam com colegas das carteiras ao lado, ou procuravam seu lugar, de volta dos 5 minutos de intervalo entre uma aula e outra. Questionada sobre o porquê de escrever a saudação na lousa, a professora de Português respondeu à pesquisadora que se tratava de "uma formalidade", pois sabia que ninguém responderia.

Distantes, professora e alunos, em conversas informais no intervalo entre as aulas, tanto ela quanto eles fizeram reclamações recíprocas - Marta queixava-se da falta de interesse e da constante falta de respeito que enfrentava, por parte dos alunos; eles, por outro lado, diziam que a aula era chata e que a professora "era velha". Certamente havia um descompasso grande entre expectativas e atitudes que, no decorrer dos dois meses de observação de aula, pareceu ser muito menos motivado por questões de caráter pessoal ${ }^{95}$ do que pelas circunstâncias da situação de ensino em que se encontravam.

Marta é uma professora que se adeqüa aos preceitos da tradição escolar (discutida e criticada no capítulo 6 deste trabalho). Portanto, para ela, ensinar Português era, substancialmente, trabalhar com GRAMÁTiCA 3 (atividades metalingüísticas). Seus alunos, por outro lado, todos com idades entre 11 e 12 anos, não compreendiam aquelas categorias metalingüísticas, nem viam propósito em aprendê-las, como confirmado em conversa após a aula com o grupo de alunos que pertenciam à sala de Inglês extracurricular. Diziam não gostar de escrever nem de ler - ainda que passassem boa parte do tempo entre o horário das aulas regulares e o do curso extracurricular de Inglês na sala de informática, na Internet, lendo orkut e escrevendo

\footnotetext{
${ }^{93}$ Fato relatado pela professora Marta, depois de algum tempo de pesquisa, ao justificar-se da frieza com que recebeu a pesquisadora nas primeiras aulas observadas, por conta do medo de ela se tratar de alguma espécie de instância ligada à coordenação do colégio.

${ }^{94}$ Dos quais apenas 11 eram sujeitos da minha pesquisa, pois também freqüentavam as aulas de Língua Inglesa extracurricular.

${ }^{95}$ Por ocasião das festas juninas, a pesquisadora teve a oportunidade de observar o relacionamento extraclasse de Marta com os alunos, que pareceu muito mais amistoso do que aquele verificado dentro de sala de aula.
} 
mensagens para os amigos. Ainda que Marta soubesse disso (a pesquisadora comentou com a professora essa questão aparentemente paradoxal), em nenhum momento cogitou aproveitar desse interesse verdadeiro pela leitura e pela escrita de seus alunos em benefício de suas aulas. Antes, dizia que "isso [a Internet] era perda de tempo". Outro motivo que arrolava para a não utilização de atividades diferentes àquelas comentadas a seguir era a "necessidade se cumprir com o programa", que era "apertado" e não dispunha de muito tempo para outras atividades.

Apesar da ênfase em atividades metalingüísticas (GRAMÁTICA 3) observada nas aulas, segundo o programa para o $2^{\circ}$ bimestre de 2005, o objetivo central do estudo de Língua Portuguesa na $7^{a}$ série é "desenvolver estratégias de leitura tornando-a eficiente". Para tanto, os alunos deveriam ser levados a

[...] reconhecer a notícia como gênero e produzi-la empregando, com propriedade, os recursos pertinentes a essa tipologia textual; conjugar e aplicar, em diferentes contextos, os verbos irregulares no modo Indicativo e Subjuntivo; apropriar-se e fazer uso de regras de acentuação; e ler efetivamente, compreender e interpretar textos variados, inclusive a obra paradidática escolhida. (ANEXO A).

A confusão entre estratégias que tenham resultado na qualidade da leitura e o domínio da GRAMÁTICA 3 (atividades metalingüísticas) expõe a contradição que fundamenta o programa dessa escola: por um lado, as exigências dos PCN que orientam, ainda que de forma vaga, a prioridade da leitura e da escrita sobre o domínio da metalinguagem; por outro, a tradição escolar, que prega a importância do ensino da metalinguagem para a boa escrita.

Ao tentar conciliar entendimentos tão distantes sobre o papel do ensino de Língua Portuguesa, no programa transparece a pouca convicção com que os trabalhos de leitura e escrita são realizados na prática. Não por acaso, a distribuição do tempo das atividades realizadas em sala, revela que $70 \%$ desse tempo foram dedicados ao ensino da GRAMÁTICA 3, acima, inclusive, da média relatada pelos trabalhos de Semeghini-Siqueira (2006c), conforme se observa na figura 5. 


\section{RELAÇÃO ENTRE TEMPO E ATIVIDADE REALIZADA NA AULA DE LÍNGUA PORTUGUESA}

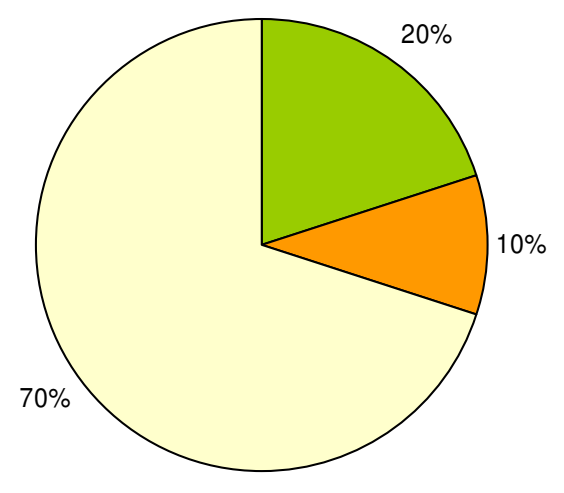

Figura 5 - Relação entre tempo e tipo de atividade realizada na aula de Português

Esses exercícios constituíram principalmente na elaboração de tabelas com a flexão verbal em todas as pessoas e tempos verbais, corrigidas na lousa pela professora, e na aplicação de regras de acentuação em listas de palavras.

Ocupando o centro das aulas observadas, os exercícios com tempo verbal eram elaborados a partir de duas fontes: a "inspiração" do momento da professora e verbos utilizados de forma incorreta nos textos escritos pelos alunos durante um Estudo de Meio ${ }^{96}$, realizado uma semana antes da chegada da pesquisadora. Ainda que representasse uma intenção entre relacionar o trabalho realizado pelos alunos e o conteúdo dos exercícios, a tentativa não os diferenciava daqueles simplesmente provindos da imaginação da professora, uma vez que a condução de ambas as atividades era idêntica: colocava-se o verbo na lousa e se pedia, ora para conjugá-lo no tempo verbal e no modo pedido pela professora, ora para corrigi-lo na frase escrita pelo aluno, explicando-se a correção pelo tempo e pelo modo verbal corretos.

Considerou-se que ocorreu GRAMÁTICA 2 (atividades epilingüísticas) em apenas 10\% do tempo decorrido da observação de aula. Ainda que o propósito da cruzadinha de verbos praticamente a invalidasse enquanto tal, pois se tratava da "avaliação bimestral de gramática",

\footnotetext{
${ }^{96}$ Trata-se do nome dado por essa escola a excursões. O Estudo do Meio referido aqui se constituiu de uma viagem a Santos (SP), de duração de um dia.
} 
o exercício, que consistia em uma cruzadinha cujas dicas das palavras a serem completadas eram o tempo e o modo de determinados verbos, previa, em sua montagem, a necessidade de que uma letra de um verbo na horizontal "ajudasse" na conjugação de um verbo na vertical, possibilitando, mesmo que de forma muito limitada, a experimentação por parte daqueles alunos que não sabiam de cor a conjugação dos verbos.

Nos $20 \%$ do tempo restante, foram realizadas atividades de reescrita de texto (aquela anteriormente citada, sobre o Estudo de Meio). Baseando-se em um código de correção que havia sido distribuído aos alunos no início do ano (Anexo B), Marta devolveu todas as "redações" corrigidas para os alunos. Suas correções privilegiaram aspectos exclusivamente ortográficos, de pontuação, acentuação e relacionados a tempos ou modos verbais utilizados inadequadamente, porque "são esses os conteúdos trabalhados nesse bimestre", alegou a professora.

Quando os alunos recebiam os textos, nenhum sabia o que significava o código do qual a professora havia se utilizado. Não só a tabela de códigos de correção não fazia o menor sentido para aqueles alunos, quanto os erros não eram identificados por eles como tais. Como solução para o impasse, a professora passou, de carteira em carteira, esclarecendo dúvidas - e indicando as correções a serem feitas - para cada um dos alunos, ocupando um tempo enorme da aula sem proveito algum nem para o aluno, que recebia a resposta pronta, nem para o grupo, que se dispersou na bagunça. Portanto, a rigor, não houve reescrita pelos alunos, mas correção de texto.

Nesse contexto descrito, ainda que o livro didático não representasse a imposição de um programa a ser cumprido e a professora possuísse meios para desenvolver um trabalho real com leitura e escrita, a força da tradição de um ensino baseado na exercitação da metalinguagem e na aplicação de regras do "bem escrever" fez-se presente em todas as aulas observadas. Em nenhum momento, considerou-se partir das necessidades reais dos alunos para a realização de uma atividade, sendo que o mais próximo que se chegou a isso foram aos tristes exercícios de conjugação verbais já descritos.

Dessa forma, embora a aula de Português possuísse a maior carga horária do currículo da $6^{\mathrm{a}}$. série ( 5 aulas semanais de 45 minutos cada), boa parte do seu tempo era gasto em atividades que se alongavam muito além do necessário, causando grande tédio ou inquietação nos alunos 
presentes. Além disso, a pequena diversidade de tipos de atividades relacionados à escrita, assim como o excesso de exercícios da GRAMÁTICA 3 (atividades metalingüísticas) faziam com que nada acontecesse para atingir o objetivo proposto, que era "desenvolver estratégias de leitura tornando-a eficiente" (Anexo A).

\subsubsection{E na aula de Português? Onde estão os jogos?}

Em todas as aulas de Português observadas ocorreu apenas um jogo, ou, pelo menos, foi assim que Marta o definiu. Isso porque a atividade não foi conduzida de maneira a criar situação lúdica alguma. Antes, foi como se os alunos estivessem fazendo outro exercício de GRAMÁTICA 3, o que não deixou de ser uma verdade.

Assim, a cruzadinha foi concebida como uma atividade que partia dos próprios erros que os alunos cometeram com relação à conjugação de verbos na notícia que escreveram sobre o Estudo de Meio. Embora partisse de um referencial contextualizado e pudesse servir como momento de reflexão e pesquisa para a solução dos problemas apresentados no texto, sua condução foi realizada visando apenas a avaliação do conteúdo "aprendido".

Mais do que isso, a metalinguagem acompanhou todas as etapas da realização da cruzadinha, pois os alunos deveriam escrever como dica da palavra o modo, o tempo e a pessoa em que o verbo estava, descontextualizando, para quem fosse resolvê-la, a palavra de sua origem (que era a redação).

Ainda que esse problema não invalidasse a atividade enquanto jogo, tornando-o apenas em um exercício de GRAMÁTICA 3 “disfarçado", a sua função de reflexão sobre a língua foi completamente perdida.

Depois de pronta, a cruzadinha foi entregue à Marta, que se deu ao trabalho descomunal de resolver todas elas e, duas semanas depois, devolvê-las corrigidas e com nota para que um colega as resolvesse novamente.

O grande problema, porém, consistiu no fato de que a atividade serviu de avaliação do bimestre sobre os verbos. Embora haja muitas questões sobre a conceituação de jogo, assim como a validade do jogo educativo, como já foi discutido anteriormente, um aspecto que 
parece ser indiscutível para que qualquer atividade receba o nome de jogo é o seu caráter de processo, e não de resultado (HUIZINGA, 2004) e (BROUGÈRE, 1995). Se o peso de avaliação é certamente um elemento indesejável para qualquer atividade, para um jogo, ele simplesmente significa o fim do elemento lúdico. Tanto que os alunos se comportaram durante o exercício da cruzadinha da mesma forma com que faziam em todas as outras atividades - indiferentes ao que estava sendo feito ou dito pela professora. $\mathrm{O}$ interesse apareceu apenas na hora de corrigir os problemas e devolvê-la para a professora, porque aí implicava nota.

A rigor, portanto, não houve jogo algum na aula de Português durante as todas as observações feitas.

\subsection{Articulando as observações das aulas de Língua Portuguesa e Língua Inglesa}

Embora muitos dos procedimentos observados na aula de Língua Inglesa, se transplantados à de Língua Portuguesa, não fariam sentido algum - uma vez que o desafio daquela consistia em justamente estruturar enunciados em uma língua ainda não dominada completamente pelos alunos - algumas aproximações contribuem positivamente para a reflexão que aqui se pretende.

Entre os elementos identificados para a análise comparativa que pudessem contribuir para a compreensão sobre a forma, o motivo e o momento de inserção das atividades de caráter lúdico no contexto da sala de aula de Língua Portuguesa e de Língua Inglesa, foram elencados (1) a utilização do tempo de sala de aula; (2) a dinâmica / variedade de atividades ocorridas; (3) o tipo de trabalho dispensado à gramática.

Se comparadas as aulas de Inglês e de Português em termos de utilização do tempo, é possível depreender que naquela houve uma variedade muito maior, não apenas de tipos de atividades desenvolvidas, mas também, de abordagens gramaticais, e, portanto, o tempo foi empregado de uma forma muito mais produtiva do que na de Língua Portuguesa. 
Como decorrência direta dessa observação, a pesquisadora identificou a maior participação dos alunos na aula de Inglês do que na de Português, assim como a baixa ocorrência de indisciplina naquela se comparado a essa. Aparentemente isso se deveu:

- a praticamente não existência de "tempo morto", improdutivo, durante a aula de Língua Inglesa, dado o fato de a professora monitorar constantemente a execução de todas as atividades;

- a realização de atividades que privilegiaram diferentes habilidades e a constante variação de arranjos de padrões de interação (atividades individuais, em pares, em grupos ou com a sala toda), que pareciam propiciar a aprendizagem de todos os alunos, não somente daqueles cuja compreensão depende de raciocínio analítico (ou da paciência para ouvir o professor falar);

- a oportunidade de interação verdadeira promovida pelas atividades lúdicas, que aproximavam os alunos uns aos outros, possibilitando que se conhecessem melhor e pudessem dividir opiniões com mais naturalidade do que na aula de Língua Portuguesa, onde o esquema de "panelinhas" impedia a livre circulação dos alunos (e de idéias) por todos os grupos. Essa aproximação também se dava entre os alunos e a professora, embora ela apenas conduzisse essas atividades. Ao ser "cúmplice" da imaginação de seus alunos, Ingrid parecia ser mais bem aceita pelo seu grupo de alunos do que Marta.

Nesse sentido, a opção pelo uso de atividades lúdicas em diferentes etapas da aula de Língua Inglesa e com propósitos diversos - mas sempre integradas às demais atividades realizadas, não representando apenas um recurso avulso de sentido ou de propósito recreativo - provouse muito eficiente, tanto em termos de estimulação da criatividade desses alunos quanto do envolvimento na aula.

A utilização dos procedimentos de briefing e debriefing no curso de inglês extracurricular revelou-se muito eficiente na medida em que contextualizava as atividades lúdicas, além de clarificarem seus propósitos pedagógicos, o que pareceu contribuir muito para que os jogos observados na aula de Língua Inglesa fossem bem sucedidos. 
Assim, ao possibilitarem a interação verdadeira, as atividades lúdicas funcionaram não apenas como veículo para a exercitação de conteúdos recém aprendidos, mas da imaginação daqueles alunos. Por meio do lúdico, relacionavam experiências já vividas a expectativas acerca de suas ações no mundo fora da sala de aula. Por esse motivo, o jogo funcionou nas aulas acompanhadas de Língua Inglesa como o principal recurso criativo, do qual a professora dispunha para captar a atenção dos alunos.

Freqüentando há apenas um ano e meio o referido curso de idiomas, os alunos de Inglês eram capazes de se comunicarem (ainda que com muitas limitações se comparado à fluência de uma língua materna) tanto oralmente quanto por escrito. Notou-se certo domínio das estruturas recém aprendidas e bom domínio daquelas que já haviam sido objeto de estudo em outros módulos, o que deixa entrever a eficiência do método. Já os alunos de Língua Portuguesa, todos falantes nativos desse idioma, eram muito capazes de expressar oralmente suas idéias, mas apresentavam um desempenho escrito aquém daquele esperado, se comparado com o de Língua Inglesa, como pode ser constatado pelas produções incluídas nos Anexos C e D.

Tendo em vista esse resultado, passou-se para a segunda etapa deste projeto: a realização de um minicurso de oralidade, leitura e escrita em Língua Portuguesa utilizando-se de atividades lúdicas. 
UMA PROPOSTA PARA A UTILIZAÇÃO DO LÚDICO NA SALA DE AULA DE LÍNGUA PORTUGUESA NO FUNDAMENTAL II: TRABALHANDO COM ATIVIDADES LINGÜÍSTICAS E EPILINGÜÍSTICAS 
6. UMA PROPOSTA PARA A UTILIZAÇÃO DO LÚDICO NA SALA DE AULA DE LÍNGUA PORTUGUESA NO FUNDAMENTAL II: TRABALHANDO COM ATIVIDADES LINGÜÍSTICAS E EPILINGÜÍSTICAS

\author{
O jogo \\ $O$ verdelhão no choupo \\ - E que mais? \\ O choupo no céu azul \\ - Eque mais? \\ O céu azul dentro d'água \\ - E que mais? \\ A água na folhinha nova \\ - E que mais? \\ A folha nova na rosa \\ - Eque mais? \\ A rosa em meu coração \\ - Eque mais? \\ E o meu coração no teu!
}

Manuel Bandeira ${ }^{97}$

Os tópicos aqui apresentados, em si, não têm nada de novo. Seus pilares são todos bem conhecidos: o uso de Avaliação Diagnóstica e Formativa (SEMEGHINI-SIQUEIRA, 2006c), como ponto de partida para a elaboração de atividades a serem realizadas em sala de aula; de seqüências didáticas (SHNEUWLY; DOLZ; NOVERRAZ, 2007), como orientação para o encadeamento produtivo dessas atividades; de atividades epilingüísticas e lingüísticas (SEMGHINI-SIQUEIRA，1977，1997，2001，2005，2006b，2006c; FRANCHI, 1991; GERALDI, 1985, 1991, 2002; TRAVAGLIA, 1996; POSSENTI, 1996), como procedimento de integração do lúdico (KISHIMOTO, 1992, 1994, 1998, 2001, 2007), (MACEDO; PETTY; PASSOS, 2000) e (CROOKALL; OXFORD, 1990) ao ensino e aprendizagem

\footnotetext{
${ }^{97}$ BANDEIRA, M. Estrela da vida inteira. Rio de Janeiro: Ed. Nova Fronteira, 1993, p. 418.
} 
(VYGOTSKY, 2003), (PIAGET, 1990), (BRUNER, 1973) e a estruturação metodológica dessas atividades por meio do TBLT (ELLIS, 2003; NUNAN, 2004).

A novidade, portanto, é a confluência de todas essas experiências bem sucedidas com o propósito de enriquecer a prática do ensino e aprendizagem de Língua Portuguesa. O fio que cose esse entrelaçamento é o uso de atividades lúdicas em todas as etapas do ensino - não se restringindo apenas, como disse Rivonlucri (2004, p. 6), a "[...] uma sexta-feira a tarde, quando todo mundo está cansado e está chovendo ${ }^{98,}$.

\subsection{A proposta: Minicurso de oralidade, leitura e escrita}

O "Minicurso de oralidade, leitura e escrita" foi oferecido a nove alunos de $6^{\mathrm{a}}$. a $8^{\mathrm{a}}$. série do ensino Fundamental II de uma escola da prefeitura de São Paulo e teve como objetivo auxiliar o desenvolvimento dessas habilidades por meio de uma abordagem lúdica.

As atividades realizadas ao longo das 22 horas de aula, distribuídas em dois meses, novembro e dezembro de 2006, pautaram-se pelo programa apresentado na Quadro 6.

Seguindo as recomendações de Semeghini-Siqueira (1997), os trabalhos iniciaram-se pela realização de uma AvALIAÇão DiAgnóstiCA E FormATIVA (ADeF) ${ }^{99}$. Optou-se pela escrita de uma carta de apresentação pessoal endereçada à professora. Essa escolha se deu por dois motivos: (1) por se tratar de uma finalização adequada às atividades programadas para o primeiro dia de aula, que revolviam em torno da apresentação dos alunos, da professora e do curso; e (2) por ser um gênero muito presente no cotidiano do adolescente, por meio do $e$-mail e dos chats, e, portanto, ser capaz de simular o uso real que esses alunos fazem da língua escrita.

O trabalho com o gênero textual entrevista como eixo orientador para as atividades posteriores foi decorrência da constatação de que a maioria dos problemas apresentados na

\footnotetext{
98 “[...] Friday afternoon, when everybody is tired and it's raining.” (tradução nossa)

${ }^{99}$ Cujo detalhamento encontra-se descrito na seção 6.2.
} 
AVALIAÇÃo DiAgNÓSTICA E FORMATIVA relacionava-se à passagem da língua falada para a língua escrita. Para o melhor aproveitamento desses alunos, foi necessário que, antes de se tratar sobre a entrevista, fosse realizada uma introdução a algumas das características do tipo de discurso jornalístico ${ }^{100}$.

\section{Apresentação}

2. Realização da Avaliação Diagnóstica e Formativa

3. Atividades com o TIPO DE DISCURSO JORNALÍSTICO:

3.1. Hipótese de texto jornalístico

3.2. Contacto com material legítimo (modelo)

3.3. Características do texto jornalístico: público alvo; meio/veículo; manchete/lead/ pirâmide invertida

3.4. Retorno à hipótese de texto jornalístico

\section{Atividades com o gênero ENTREVISTA}

4.1. Primeira produção: hipótese de entrevista

4.2. Módulo 1: Apresentação e análise de modelo de entrevista

4.3. Módulo 2: Teste de modelo

4.3.1. Escrita coletiva

4.3.2. Reescrita coletiva

4.3.3. Reescrita individual

4.4. Módulo 3: Coleta de dados

4.5. Módulo 4: Transcrição das entrevistas

4.6.1. Reescrita coletiva

4.6.2. Reescrita individual

4.7. Produção final: Ampliação da hipótese inicial sobre entrevista: REFLEXÃO FINAL e AVALIAÇÃO

Quadro 6 - Programa das atividades realizadas no minicurso de oralidade, leitura e escrita

O trabalho com o gênero textual entrevista, como eixo orientador para as atividades posteriores, foi decorrência da constatação de que a maioria dos problemas apresentados na AvaliaÇÃo DiagnóstiCA E FoRMATIVA relacionava-se à passagem da língua falada para a língua escrita. Para o melhor aproveitamento desses alunos, foi necessário que, antes de se

\footnotetext{
${ }^{100}$ Nomenclatura segundo Maingueneau (2002, p. 61).
} 
tratar sobre a entrevista, fosse realizada uma introdução a algumas das características do tipo de discurso jornalístico ${ }^{101}$.

A seleção dos conteúdos trabalhados em sala de aula seguiu os princípios defendidos por Schneuwly e Dolz (2007, p.82):

O princípio da legitimidade (referência aos conhecimentos que emanam da cultura ou elaborados por profissionais especialistas); princípio de pertinência (referência às capacidades dos alunos, às finalidades e objetivos da escola, aos processos de ensino/aprendizagem); princípio de solidarização (tornar coerentes os conhecimentos em função dos objetivos visados).

Portanto, a relevância do trabalho escolar com textos jornalísticos, em especial, com entrevistas, para adolescentes está no papel que a mídia desempenha na sua vida e no seu imaginário. Isso, porém, não significa que a informação mediatizada seja por ele plenamente compreendida, nem que haja um posicionamento crítico a seu respeito. Ao revelar os meios pelos quais esses textos são produzidos, objetivou-se não só o desenvolvimento de estratégias que aprimorassem suas habilidades de leitura e de escrita, mas sim, de recursos capazes de levar aqueles alunos à reflexão sobre sua própria relação com os textos produzidos pela mídia, contribuindo para sua leitura de mundo.

Procurou-se, assim, trabalhar elementos próprios da entrevista, como a relação entre públicoalvo e veículo de publicação/meio, a formatação do texto em manchete, lead/sub-lead e pirâmide invertida (OLIVEIRA, 1991), sem se desconsiderar a possibilidade de transferência desse conhecimento para outros gêneros textuais, como sugere Schneuwly e Dolz (2007, p. 80):

[...] toda introdução de um gênero na escola é o resultado de uma decisão didática que visa a objetivos precisos de aprendizagem que são sempre de dois tipos: trata-se de aprender a dominar o gênero, primeiramente, para melhor conhecê-lo ou aprecia-lo, para melhor saber compreendê-lo, para melhor produzi-lo na escola ou fora dela e, em segundo lugar, para desenvolver capacidades que ultrapassam o gênero e que são transferíveis para outros gêneros próximos ou distantes.

\footnotetext{
${ }^{101}$ Nomenclatura segundo Maingueneau (2002, p. 61).
} 
Quanto ao trabalho com questões relacionadas à linguagem, seguindo as orientações de Eglê Franchi (1984), Carlos Franchi (1991), Geraldi (1985, 1991, 2002), Travaglia (1996), Possenti (1996), Perini (2005) e Semeghini-Siqueira (1997, 1998, 2001, 2005, 2006a, 2006b, 2006c), privilegiou-se o uso de atividades lingüísticas e epilingüísticas, em detrimento da exercitação metalingüística. Essa orientação metodológica está completamente consoante com o que Schneuwly, Dolz e Noverraz (2007, p. 114) propõem, pois, segundo os autores, as seqüências "[...] visam ao aperfeiçoamento das práticas de escrita e de produção oral e estão principalmente centradas na aquisição de procedimentos e de práticas [...]”, mas, ao mesmo tempo, “[...] constituem um lugar de intersecção entre atividades de expressão e de estruturação [...]”, ainda que não possam “[...] assumir a totalidade do trabalho necessário para levar os alunos a um melhor domínio, da língua e devem apoiar-se em certos conhecimentos, construídos em outros momentos."

Referindo-se a esses “conhecimentos”, Schneuwly, Dolz e Noverraz (2007, p. 115) indicam um caminho para o trabalho com a sintaxe, a ortografia e o uso equivocado da morfologia verbal. Contrariamente ao que a pratica a tradição escolar brasileira (discutida no capítulo 4, seção 1.1.), esses autores propõem que:

As pesquisas feitas sobre os processos de aprendizagem mostram [...] que dar aos alunos múltiplas ocasiões para escrever é uma condição indispensável para favorecer o desenvolvimento de suas capacidades nesse domínio (em referência à ortografia).

E (SHNEUWLY; DOLZ; NOVERRAZ, 2007, p. 116),

[...] o domínio (da sintaxe) [...] passa pela compreensão e pela apropriação das regras gerais que dizem respeito à organização da frase e necessita de conhecimentos explícitos sobre o funcionamento da língua nesse nível. Trata-se, portanto, desenvolver nos alunos capacidades de análise que lhes permitam melhorar esses conhecimentos. Para tanto, é essencial reservar tempo para um ensino específico de gramática ${ }^{102}$, no qual o objeto principal das tarefas de observação e de manipulação é o funcionamento da língua. A bagagem que os alunos terão acumulado ao longo desses momentos de reflexão específica poderá ser reinvestida, com proveito, nas tarefas de escrita e de revisão previstas nas seqüências. Em contrapartida, as seqüências permitirão contextualizar certos objetivos de aprendizagem e dar-lhes mais sentido.

\footnotetext{
${ }^{102}$ Em nota, a tradutora do original em francês esclarece: "Aqui, os autores referem ao que tem sido tratado, no Brasil, como atividades de caráter epilingüístico."
} 
Assim, não se recorreu em momento algum a atividades metalingüísticas em sala de aula.

Todas as atividades lingüísticas e epilingüísticas realizadas nesta proposta procuraram integrar uma ou mais das características apontadas por Macedo, Petty e Passos (2005, p. 15) como essenciais para uma atividade lúdica: (1) prazer funcional; (2) serem desafiadoras; (3) criarem possibilidades ou disporem delas; (4) possuírem dimensão simbólica e; (4) expressarem-se de modo construtivo ou relacional ${ }^{103}$.

Essas atividades foram estruturadas em TAREFAS seguindo os procedimentos de PRÉ-TAREFA e PÓS-TAREFA do TBLT (ELLIS, 2003) e (NUNAN, 2004), por se compreender que tal metodologia possibilita melhor aproveitamento pedagógico do recurso lúdico, uma vez que viabiliza a relação entre a diversão imediata advinda do jogo à reflexão necessária para o ensino e a aprendizagem consistente. A proximidade, em diversos aspectos, entre os pressupostos da seqüência didática descritos por Schneuwly, Dolz e Noverraz (2007) e os do Task-based language teaching, por Ellis (2003) e Nunan (2004), especialmente no que diz respeito a:

- a necessidade de uma referência no mundo real que oriente a produção de sala de aula;

- a ponto de partida do trabalho é o conhecimento de mundo do aluno;

- a busca pela independência e criatividade durante a realização das atividades;

- a preponderância de atividades lingüísticas e epilingüísticas, em detrimento das de metalinguagem;

- a avaliação que leva em conta não apenas o produto, mas o processo também

facilitou a integração de ambos os referenciais teóricos.

Recorreu-se como fonte de sugestões para as atividades lúdicas a três coletâneas de jogos aplicados ao ensino de língua estrangeira editadas por Ur (2001), Wright, Betterridge e Buckerby (1993) e Rivonlucri (2004). Adaptações, evidentemente, foram feitas no sentido da adequação à situação de ensino de língua materna.

\footnotetext{
${ }^{103}$ Abordadas com maior profundidade no capítulo 2, seção 1.
} 
Embora o trabalho com leitura tenha desempenhado um papel secundário no minicurso, pois ficou restrito aos modelos e às produções dos próprios alunos, é importante que se registre a sua orientação metodológica. Optou-se pelos "modos de ler" "sobrevôo, saltos e passinhos" (SEMEGHINI-SIQUEIRA, 2006b, p. 190), cujos termos, provenientes do ensino de língua estrangeira instrumental ${ }^{104}$, assemelham-se em funcionalidade às estratégias de reading for gist, skimming, scanning, top-down reading e bottom-up reading. Vale ressaltar que os termos utilizados em língua portuguesa foram "imaginados" para o uso com crianças e jovens.

Por "sobrevôo", a autora (SEMEGHINI-SIQUEIRA, 2006b, p. 190) se refere à leitura superficial, visando apenas uma compreensão geral, auxiliada por informações gráficas, deduções decorrentes do gênero, assunto, autor, etc. No modo de ler "saltos", os pontos principais do texto são o alvo. Sua execução deve ser rápida e silenciosa, enquanto a busca do leitor deve ater-se a

[a] um tópico sobre o qual o leitor já tem conhecimentos prévios sólidos e concorda ou discorda com o autor do texto; [b] um tópico que interessa ao leitor, referente a uma informação nova sobre a qual ele tem poucos conhecimentos, mas que é relevante para a construção do conhecimento em questão. (SEMEGHINI-SIQUEIRA, 2006b, p. 191)

Quanto ao modo de ler 3, "passinhos", trata-se de um procedimento detalhado e em profundidade. Procura-se compreender o texto e as relações que subjazem a sua leitura. Semeghini-Siqueira (2006b, p. 189), porém, acrescenta que "é importante recorrer a elas, de forma lúdica, como se fosse um jogo, para alavancar essa aprendizagem e desenvolver habilidades necessárias ao ato de ler."

\subsection{Caminhos apontados pela Avaliação Diagnóstica e Formativa}

Realizada no primeiro dia de aula, a $\mathrm{ADeF}$ funcionou como o fechamento do tópico tratado naquele momento, a apresentação pessoal. Todas as atividades anteriores possuíam dupla funcionalidade: propiciar situações em que os alunos pudessem falar sobre si enquanto os demais ouviam o colega; e servirem de preparação para a realização da ADeF. Por esse

\footnotetext{
${ }^{104}$ Abordagem de ensino de língua estrangeira voltada apenas à leitura.
} 
motivo, a orientação para a atividade restringiu-se à indicação do nome do aluno e do destinatário, a professora-pesquisadora, à escrita em, no máximo, três parágrafos a respeito de si mesmo, e à necessidade de cumprimentos de saudação e despedida.

A opção pela realização da $\mathrm{ADeF}$ naquele momento, i.e., primeira aula, contrariando a sugestão de Schneuwly, Dolz e Noverraz (2007, p. 98) de a avaliação formativa (no vocabulário empregado por aqueles autores) coincidir com a produção inicial, se deu em virtude do fato de a professora-pesquisadora não conhecer os alunos de antemão - pois todos os que participaram do minicurso de oralidade, leitura e escrita o fizeram por escolha própria - e, portanto, não poder adiantar quais seriam as necessidades reais que aqueles alunos apresentariam em relação ao trabalho com escrita. Foi com base nessas necessidades que a escolha pelo trabalho com o gênero textual entrevista foi realizada.

Enquanto atividade de avaliação do grau de letramento, a TAREFA possibilitou a execução de uma amostra de extensão adequada. Além disso, por se tratar de um gênero bastante cotidiano, presente na realidade desses alunos por meio do e-mail e do chat, dispensou-se instruções complexas sobre a formatação do texto, o que não só simplificou a realização do trabalho como também, revelou o grau de envolvimento com a escrita desses alunos, pouco acostumados a escrever outros gêneros textuais senão esses na vida real.

Com relação ao conteúdo do texto, a carta também serviu para que a professora-pesquisadora pudesse conhecer um pouco mais seus alunos.

Seguindo a "GRADE para mobilizar a percepção do PROFESSOR e desencadear o processo de AVALIAÇÃO DIAGNÓSTICA E FORMATIVA [ADeF] concernente à PRODUÇÃO ESCRITA: conhecimento do GRAU DE LETRAMENTO/LITERACIA do ALUNO como estratégia para a reinvenção de práticas educacionais de LINGUAGEM" (SEMEGHINISIQUEIRA, 2002), foi possível identificar áreas problemáticas na escrita dos participantes do projeto, sendo possível planejar ações no sentido de contribuir para o desenvolvimento de sua capacidade de escrita.

Antes, porém, de que os dados sejam apresentados, algumas considerações preliminares sobre o instrumento de análise se fazem necessárias. A "Grade” (SEMEGHINI-SIQUEIRA, 2002), apresentada no Anexo E, está dividida em 10 tópicos: 
(1) “Avaliação preliminar [AP] do professor", onde são feitas as observações de caráter geral sobre cada uma das produções analisadas;

(2) "Gênero em questão e estratégia adotada pelo professor". Tópico em que constam informações sobre o trabalho com gênero realizado pelo professor anteriormente à produção escrita;

(3) "Gêneros escritos: agrupamentos a partir de tópicos mais amplos," momento em que se relaciona a produção escrita a um gênero textual;

(4) "Tipologia textual: protótipo de cada tipo de seqüência textual e elementos para a análise." Para além do que o próprio nome do tópico revela, acrescenta-se que cada tipologia textual está subdividida nos diversos itens para viabilizar uma análise detalhada sobre a presença (ou não) de cada um de seus elementos constituintes;

(5) "Organização subjacente do texto: coerência." São analisados, por exemplo, aspectos como incoerência semântica, sintática, estilística e pragmática.

(6) “Organização superficial o texto: coesão." Repetições, uso de conjunções, paragrafação, discurso direto ou indireto e pontuação compõem esse tópico;

(7) "Vocabulário;"

(8) Frequiência de "desvios" referentes ao padrão culto da língua;"

(9) "Domínio da ortografia," no nível da palavra;

(10) "Três diferentes tipos de 'Desvios ortográficos'," relativos a trocas de surdas e sonoras, interferências da oralidade e a desvios da ortografia padrão no Brasil;

(11) "Observação final", no qual se considera, tendo em vista todos os aspectos analisados da produção do aluno, se a produção escrita é plenamente satisfatório, satisfatório, razoavelmente satisfatório ou não-satisfatório.

Quadro 7 - Principais tópicos da "Grade para [...] Avaliação Diagnóstica e Formativa [...]"

(SEMEGHINI-SIQUEIRA, 2002)

Trabalhando com o gênero carta informal, individualmente e com explicitação sumária sobre as características desse gênero, apenas duas produções não se adequaram à proposta. Uma, descreveu desconexamente supostos acontecimentos passados com os familiares, e o outro, assemelhava-se à letra de uma música ou poesia, contendo uma mensagem de encorajamento $^{105}$. Isso revelou à professora-pesquisadora o desconhecimento do gênero "carta informal" para alguns esses alunos.

${ }^{105}$ Anexo E. 
Com relação à tipologia textual, ainda que oito das nove produções possuíssem remetente e destinatário, apenas quatro cumpriram com a formalidade de saudação e despedida, o que demonstra que a mensagem que deveria ser veiculada pela carta foi compreendida pela maioria, mas não o seu formato.

Com relação à coerência textual, apenas um exemplo problemático pode ser apreendido das produções. ("na vida tem" - sendo que o sentido era de "a vida tem”). Aventa-se a hipótese de que, por se tratar de um assunto acessível (apresentação pessoal) e que fora trabalhado ao longo de toda a aula, a elaboração textual tornou-se uma tarefa menos complicada; logo, os poucos problemas de coerência - o que não se refletiu na coesão textual.

O excessivo uso de repetições, a totalidade de orações simples ou períodos compostos por coordenação (cujos conectivos utilizados foram, invariavelmente, "e" e "que"), a ocorrência de textos blocados, sem paragrafação nem pontuação adequadas, foi responsável por $54 \%$ de todos os problemas apresentados nas nove produções escritas. Segundo Schneuwly, Dolz e Novarrez (2007, p. 115)

[...] as seguintes dificuldades aparecem mais freqüentemente nos textos dos alunos: utilização de frases incompletas; falta de variedade na construção das frases; utilização de coordenação mais que de subordinação; pontuação insuficiente. Essas inabilidades, freqüentemente resultantes de interferências entre sintaxe do oral e sintaxe da escrita, indicam também uma dificuldade de ordem cognitiva para hierarquizar. elementos.

Por se tratarem de marcas da interferência da oralidade na língua escrita, optou-se pelo trabalho posterior com o gênero "entrevista", no qual a diferenciação da ambas modalidades de linguagem é central.

Não houve uso de gírias, regionalismos, termos em outras línguas nem neologismos nas produções assinaladas. Também não houve maiores problemas com concordância nominal (ocorrência de um caso, "bastante filho"), nem verbal nos textos. Possivelmente, o fato do uso da primeira e da segunda pessoa do singular concorreu para esse resultado positivo. Em produções textuais posteriores, nas quais havia a necessidade do emprego de maior variedade de pessoas do discurso, os problemas foram bastante freqüentes, especialmente de concordância verbal como "nós faz" ou "a gente fazemos". 
Com relação à forma escrita das palavras, $10 \%$ das grafias apresentavam algum tipo de problema, quer seja de acentuação, quer seja de ortografia. Ocorrências significativas foram:

- Trocas de surdas por sonoras: "farias", no lugar de "várias"; "di” por "te"; "cam digo", ao invés de "contigo".

- Interferências diretas da oralidade: "teio", por "tenho"; "pode", "conhece", "melho", "fo", "se" faltando o "r" final; "bam" e "tam", sem o uso do "ão"; "mais", por "mas"; "enteligente", "di", “qui”, apresentando a confusão entre a grafia do "i" e do "e"; "nóis", acréscimo da vogal "i”" e a junção de palavras, como em "aminha".

- Desvios da ortografia padrão, como em "jentill, "ta", "tar" (estar), "em tão", "serto", “serteza”, “terca”, “inesqueciveu”, “autos” (altos), "presão”, “vir” (no lugar de "vi”), "por que" (no lugar de "porque”), “marreu”, "trenhi” (e não "trem”), “enprortante” e "aprendir".

- Problemas com acentuação: "e” ("é”), "simpática”, "veterinária”, "divertida”, “à” (a), “família", "vez", "primeiro", "serie", "familiares" e "ultimo".

Todas as produções apresentaram similarmente problemas com pontuação, tanto dentro do período ("eu tenho 14 anos estou na $6^{a}$ serie"), quanto dentro do parágrafo ("estou quase realizando um sonho eu vou fazer teste para jogar no profissional”) ou com relação ao ponto final (“A professora é muito legal e divertida passa brincadeiras divertidas e educativas"), totalizando $48 \%$ dos problemas identificados nos textos.

Relacionando-se o total de problemas apresentados nas produções escritas, obteve-se o gráfico da figura 6.

Tendo em vista de todos os critérios utilizados para a Avaliação Diagnóstica e Formativa, $33 \%$ das produções foram julgadas satisfatórias, 33\% razoavelmente satisfatórias e 33\% não satisfatórias. Todo o trabalho posterior, baseado nessas constatações, foi realizado no sentido de desenvolver estratégias para minimizar a interferência da oralidade nos textos escritos desses alunos. 


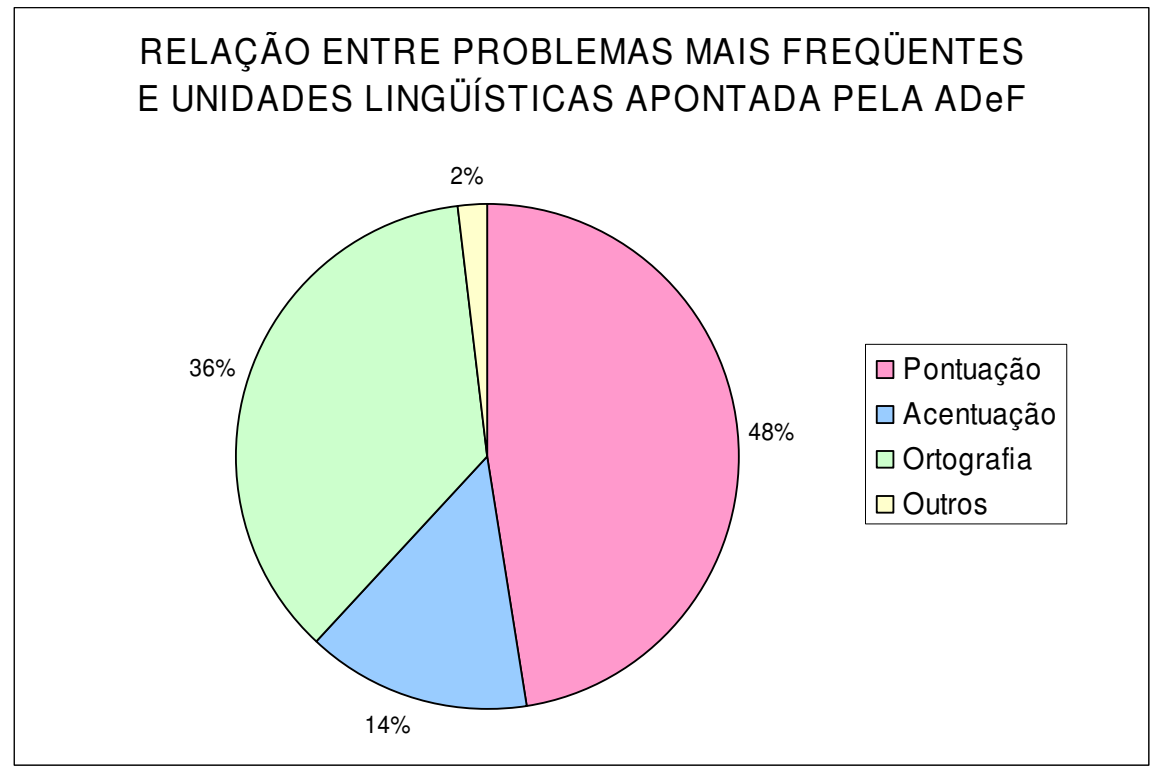

Figura 6 - Relação entre problemas mais freqüentes e unidades lingüísticas apontada pela ADeF

\subsection{A execução}

Optou-se por ordenar as anotações pela data de ocorrência da aula, para que a evolução cronológica dos eventos fosse respeitada. As atividades encontram-se numeradas de forma que seja claro sua relação com as demais realizadas no mesmo dia de aula (por exemplo, 1/2 significa que foi a primeira em uma aula em que ocorreram duas atividades). Constam também o tema, o número de alunos participantes da aula, a descrição da atividade (em forma de procedimento geral) e os comentários advindos de sua realização. Os objetivos do professor e do aluno, além do tipo de conhecimento mobilizado para a realização da atividade são informações que encerram cada ficha.

Todas as atividades foram conduzidas semelhantemente às TAREFAS do TBLT, sendo precedidas por PRÉ-TAREFAS e sucedidas por PÓS-TAREFAS. Houve a realização de briefing e debriefing ${ }^{106}$ para todas as atividades lúdicas. A menção desses procedimentos, porém, foi feita apenas quando se constituíram em outra atividade, antecedendo ou sucedendo a atividade lúdica em si.

\footnotetext{
${ }^{106}$ Definições no capítulo 2.
} 


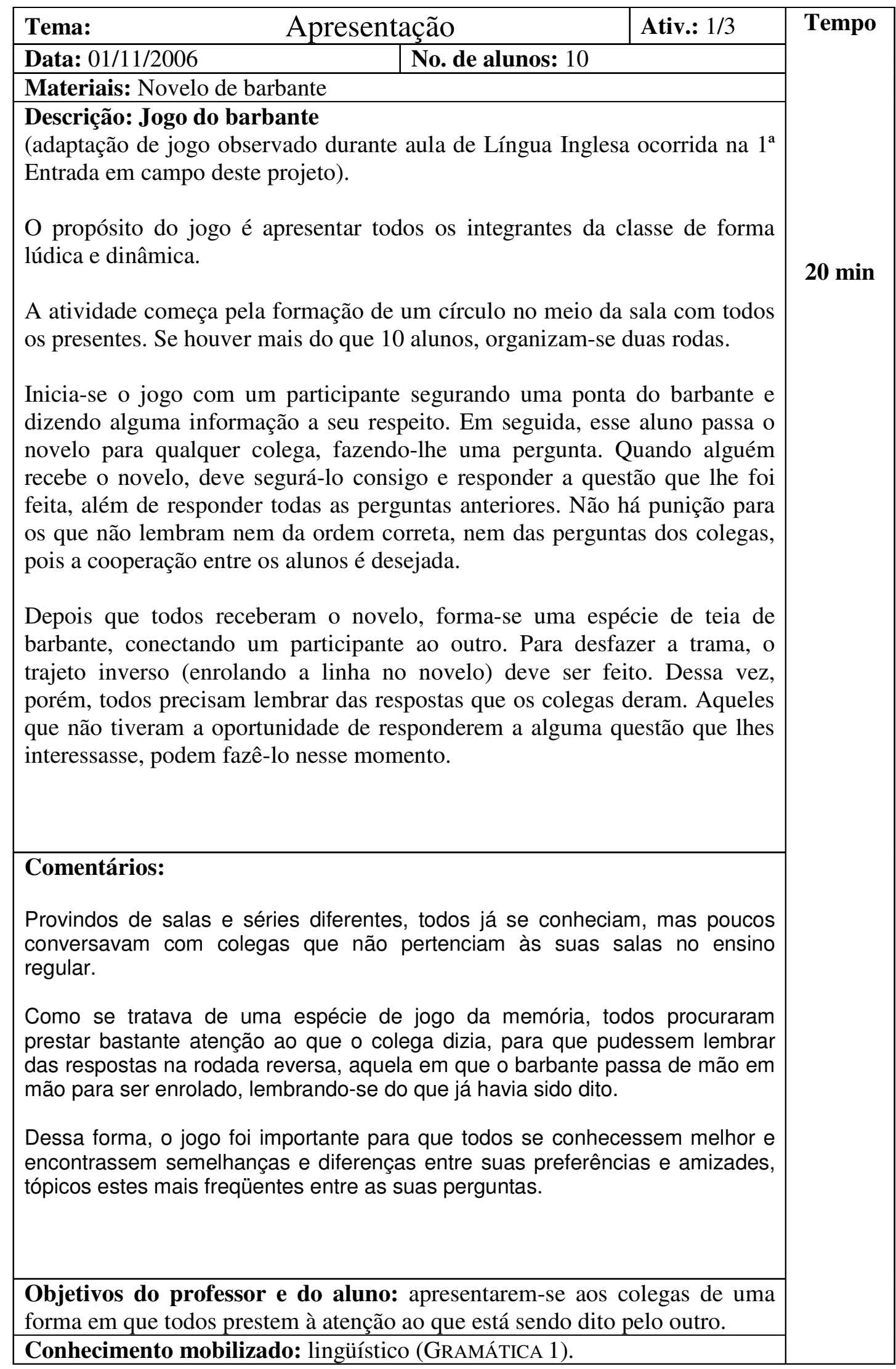




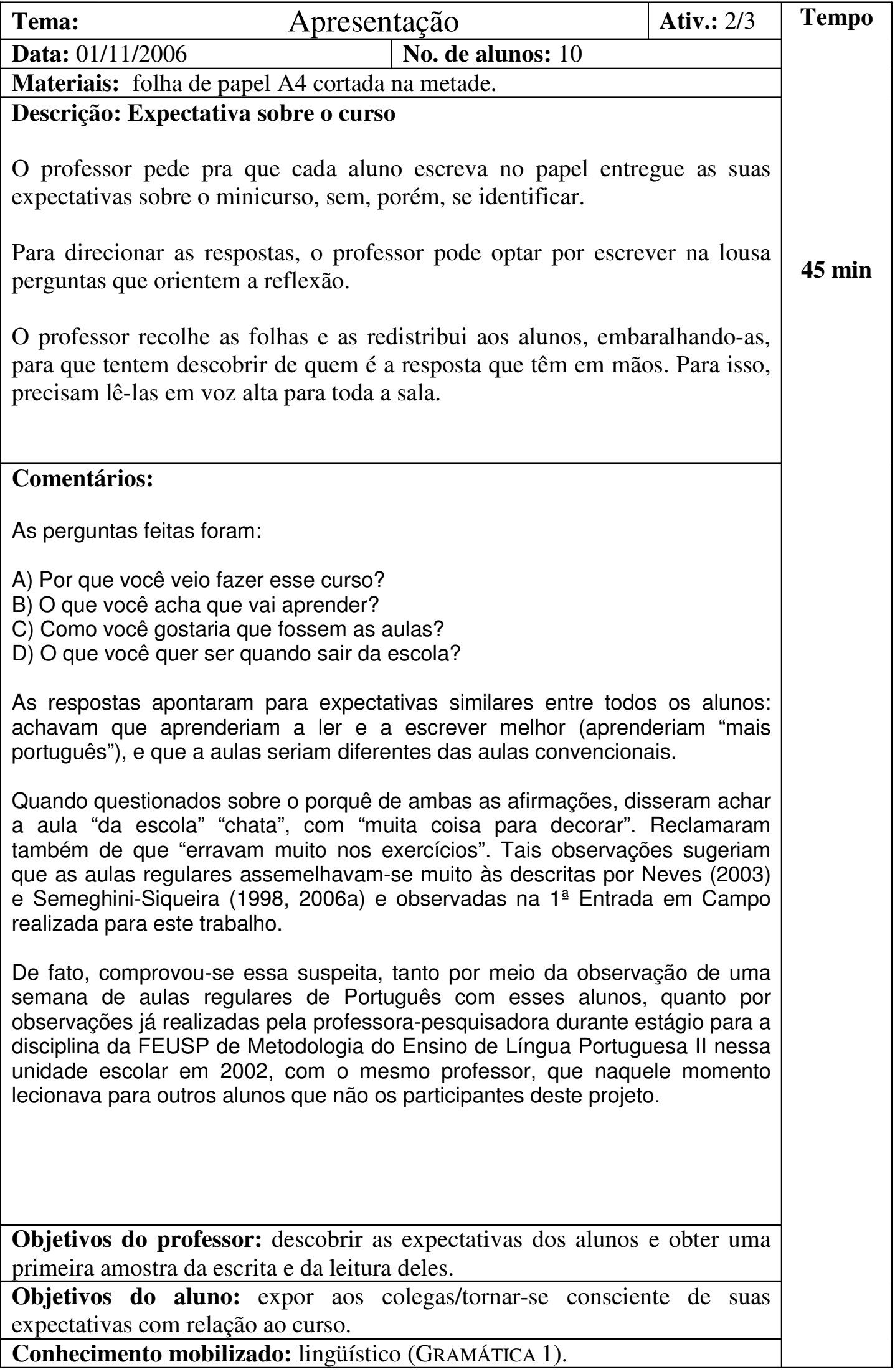




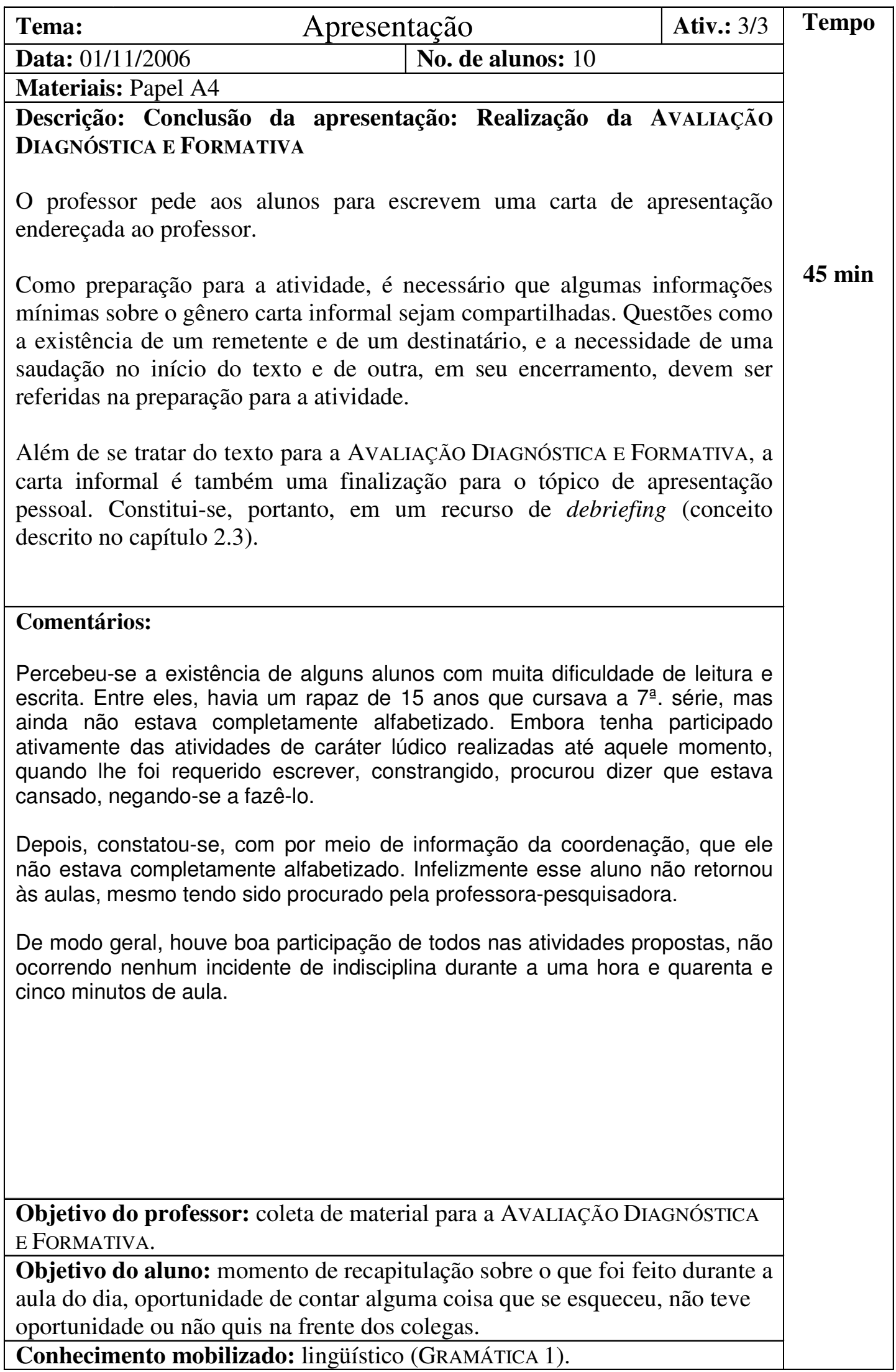




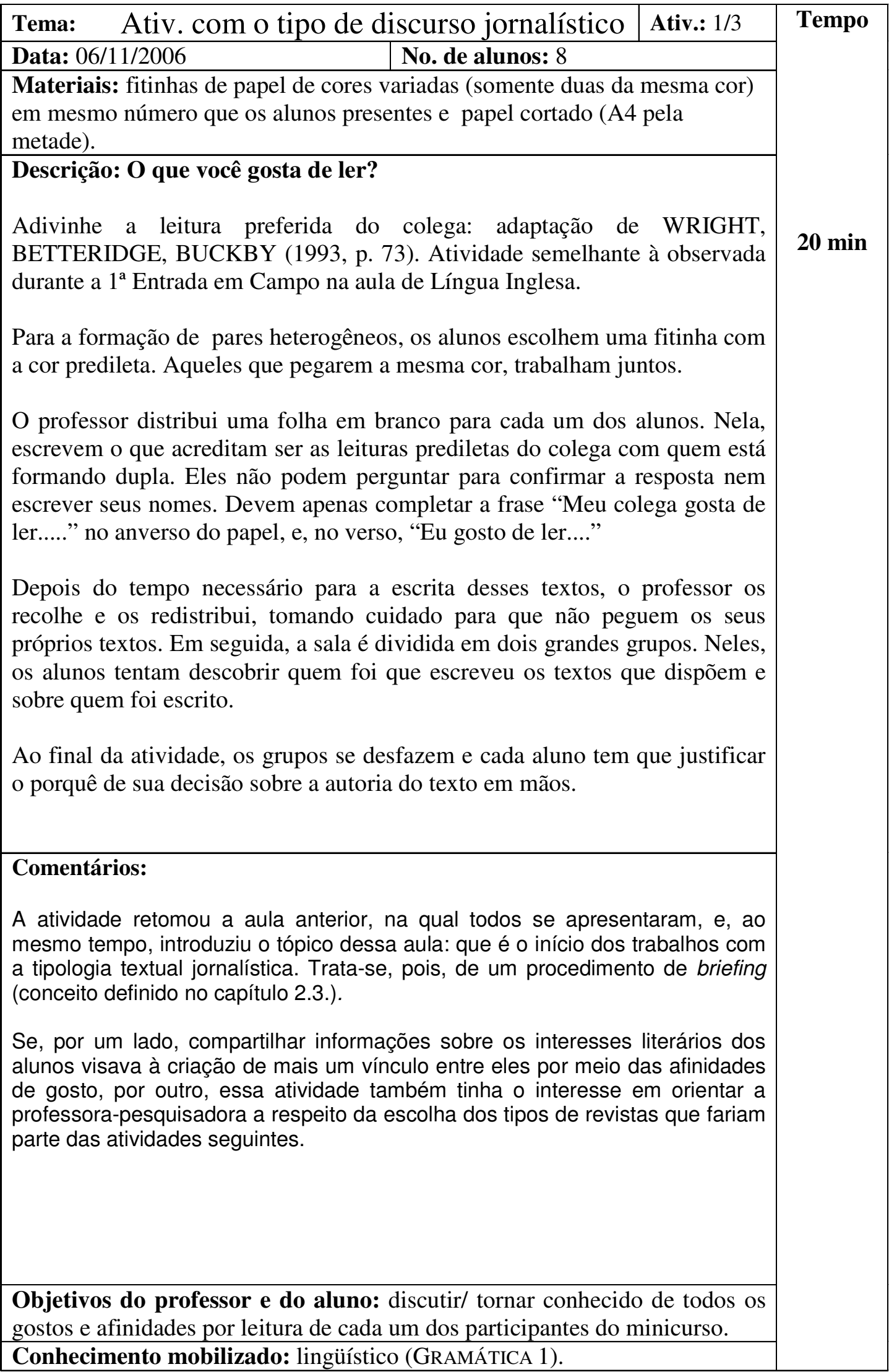




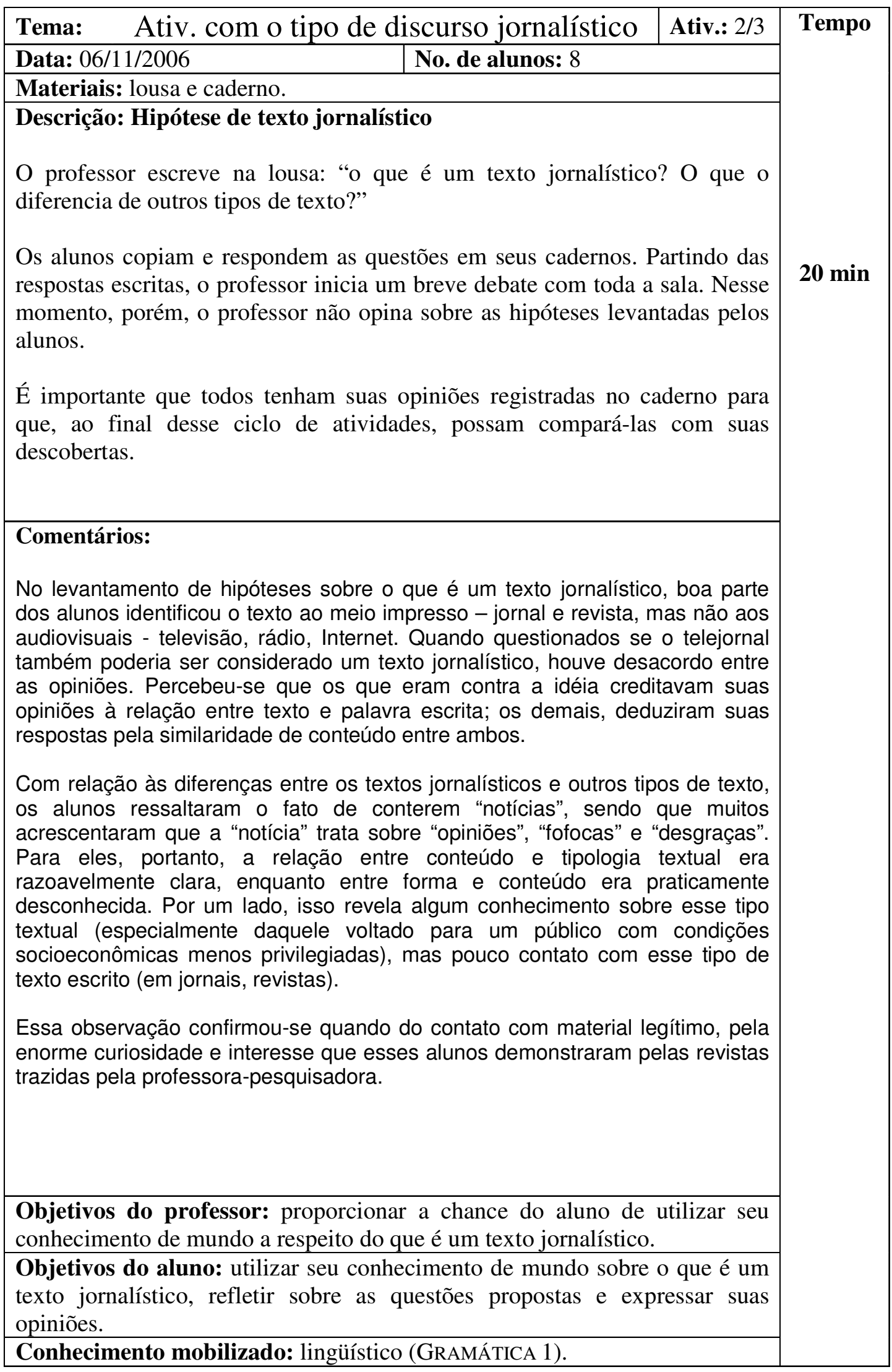




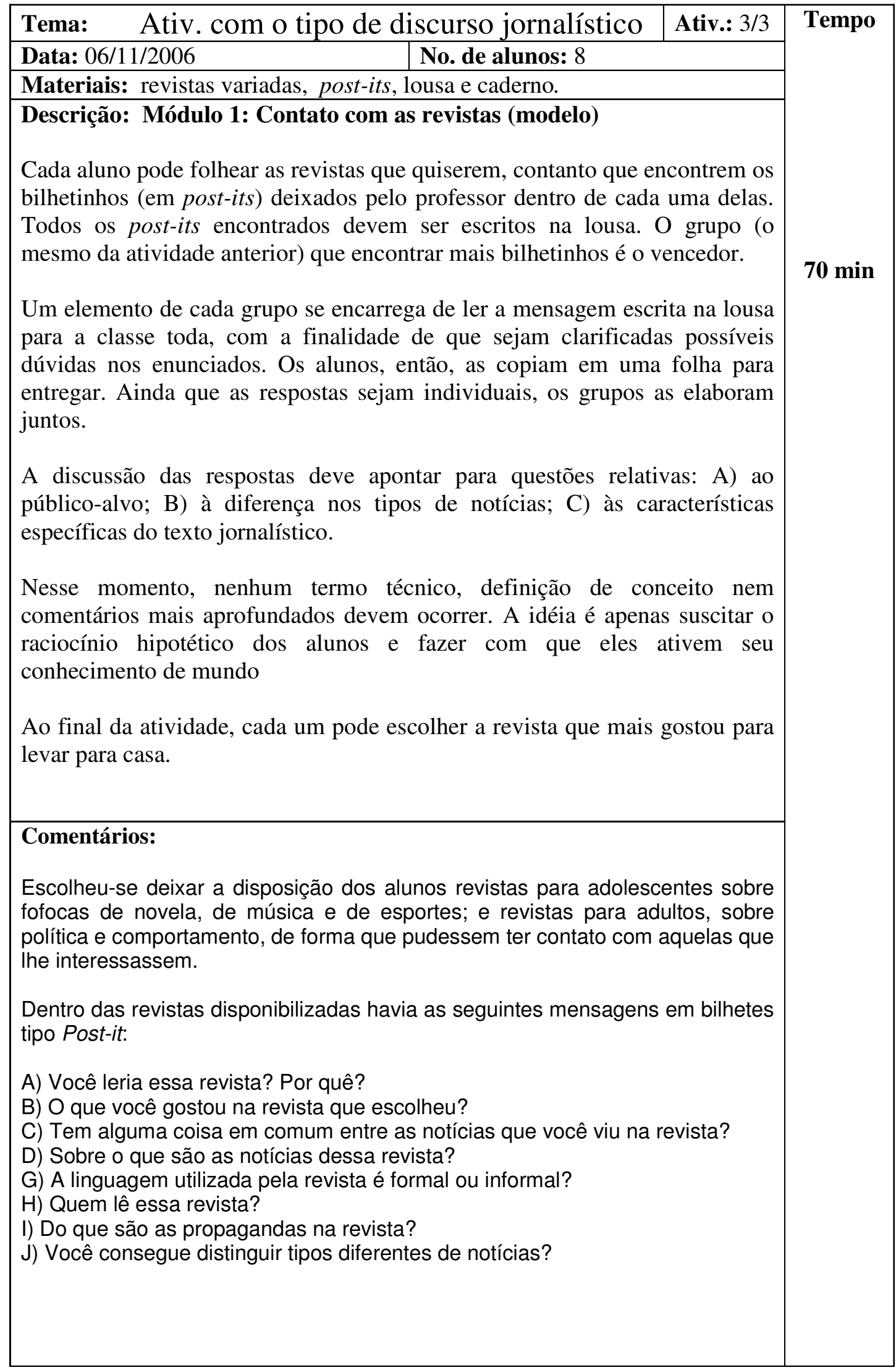




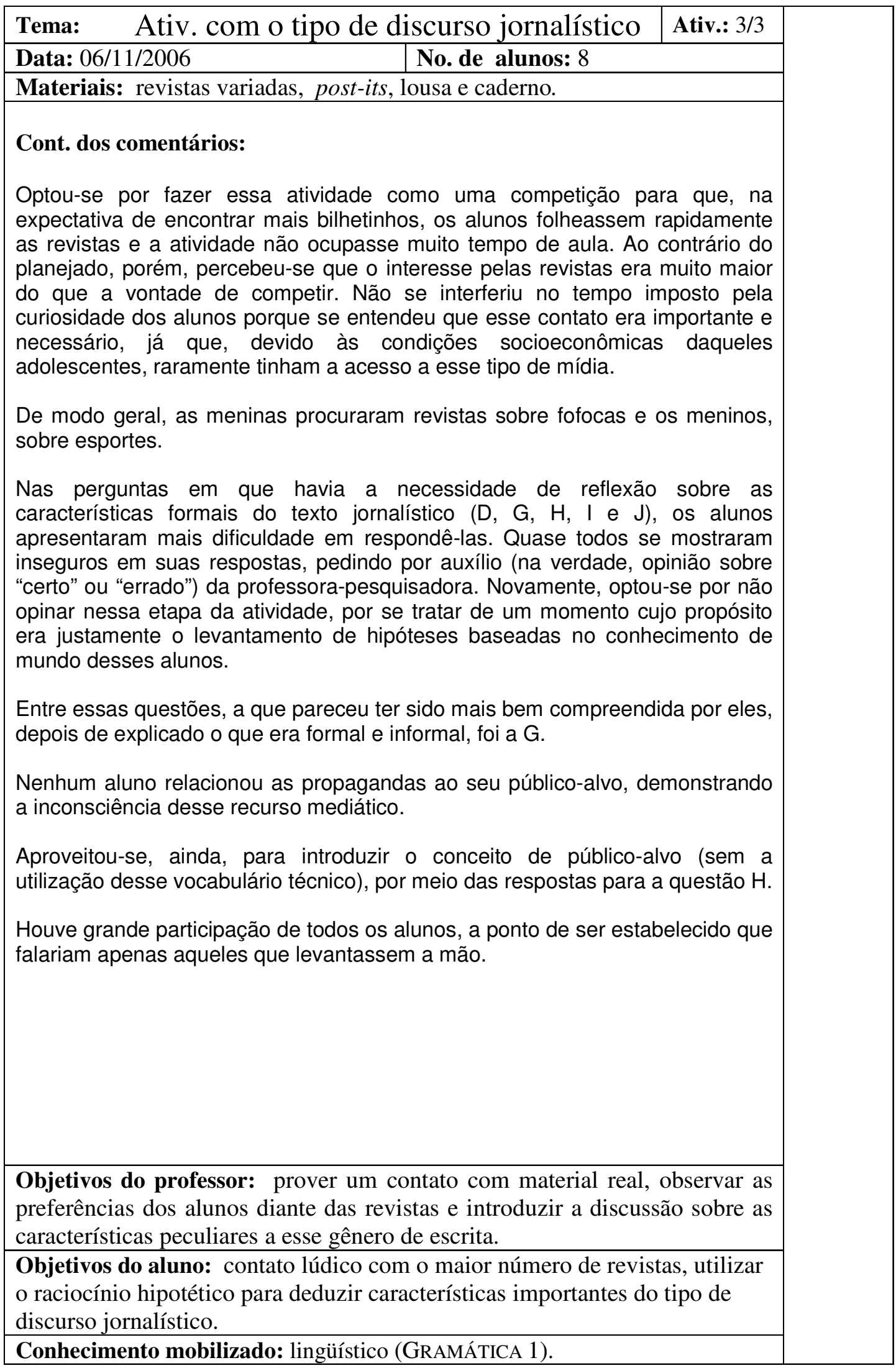




\begin{tabular}{|c|c|}
\hline \begin{tabular}{l|l} 
Ativ. com o tipo de discurso jornalístico II & Ativ.: 1/4
\end{tabular} & \\
\hline \begin{tabular}{|l|l} 
Data: $13 / 11 / 2006$ & No. de alunos: 9 \\
\end{tabular} & \\
\hline $\begin{array}{l}\text { Materiais: Tac (tipo de massinha para afixar papéis nas paredes sem } \\
\text { arrancar a tinta). Se a escola ou o professor não dispuser dela, pode ser } \\
\text { utilizado em seu lugar fita adesiva. Folha A4, figuras de pessoas } \\
\text { desconhecidas e revistas variadas. }\end{array}$ & \\
\hline $\begin{array}{l}\text { Descrição: Características do texto jornalístico: público-alvo, meio/ } \\
\text { veículo; manchete/lead/ sublead/ pirâmide invertida. }\end{array}$ & \\
\hline $\begin{array}{l}\text { Wall game (adaptação de atividade observada na aula de Língua Inglesa } \\
\text { concernente à } 1^{\text {a }} \text { Entrada em Campo desta pesquisa). }\end{array}$ & $80 \mathrm{~min}$ \\
\hline A) Público-alvo e veículo: & \\
\hline $\begin{array}{l}\text { O professor inicia a aula perguntando se os alunos acham que é possível } \\
\text { dizer alguma coisa sobre a personalidade de uma pessoa por meio da } \\
\text { aparência física dela - modo de vestir, de agir, de olhar... }\end{array}$ & \\
\hline $\begin{array}{l}\text { Depois de breve discussão, o professor escreve na lousa algumas indicações } \\
\text { visíveis que os alunos achem que possam revelar algo sobre a personalidade } \\
\text { de alguém. Essas "categorias" devem ser escritas na lousa para serem } \\
\text { utilizadas na etapa seguinte da atividade. }\end{array}$ & \\
\hline $\begin{array}{l}\text { O professor dispõe, em cada uma das paredes da sala, a figura de uma } \\
\text { pessoa. Cada uma delas representa um tipo bem diferente de indivíduo. } \\
\text { Abaixo dessas figuras, coloca-se um papel em branco para que a atividade } \\
\text { seja realizada. }\end{array}$ & \\
\hline $\begin{array}{l}\text { Pede-se para que cada aluno se dirija à figura que mais gostou (técnica de } \\
\text { formação de grupos heterogêneos). As pessoas que escolherem a mesma } \\
\text { figura trabalharão juntas até o final dessa atividade. }\end{array}$ & \\
\hline $\begin{array}{l}\text { Cada grupo passa a escrever nesses papéis como imagina serem as pessoas } \\
\text { das figuras, baseando-se nas categorias formuladas no início da aula. }\end{array}$ & \\
\hline $\begin{array}{l}\text { Quando todos terminarem de escrever suas opiniões sobre todas as figuras, o } \\
\text { professor compara as respostas e distribui para os grupos anúncios de } \\
\text { revistas diferentes e pede que para os alunos, coletivamente, decidam qual } \\
\text { desses anúncios venderia seu produto cada uma daquelas pessoas. Assim que } \\
\text { se chegar a um consenso, o anúncio deve ser afixado abaixo da figura. }\end{array}$ & \\
\hline $\begin{array}{l}\text { Depois, os grupos recebem revistas de tipos diferentes e devem decidir } \\
\text { quem, entre aquelas figuras da parede, leria essas revistas. Quando todos } \\
\text { terminarem, os grupos têm que justificar suas escolhas para a sala. Nessa } \\
\text { discussão, as escolhas que fizeram em todos os momentos do exercício } \\
\text { devem ser relacionadas à questão do que é público-alvo e de sua importância } \\
\text { para a redação de uma matéria de revista. }\end{array}$ & \\
\hline
\end{tabular}




\begin{tabular}{|l|l|l|}
\hline Tema: Ativ. com o tipo de discurso jornalístico II & Ativ.: $1 / 4$ \\
\hline Data: $13 / 11 / 2006$ & No. de alunos: 9 \\
\hline $\begin{array}{l}\text { Materiais: Tac, folha A4, figuras de pessoas desconhecidas e revistas } \\
\text { variadas. }\end{array}$
\end{tabular}

Continuação da descrição:

Os aspectos mais importantes (OLIVEIRA, 1991) a serem levantados nessa discussão são as variações determinadas pelo público-alvo referentes à:

- linguagem empregada;

- assuntos abordados;

- anunciantes;

- lay-out da revista.

O problema em se julgar alguém pela aparência (estereótipo) também é um assunto paralelo a ser abordado.

\section{B) Características específicas do texto jornalístico:}

Escolhe-se um texto de cada revista utilizada na etapa anterior da atividade para ser afixado na lousa. Depois disso, o professor pede para que os alunos venham até a lousa em seus grupos, observem os textos e os comparem, procurando por características similares.

Quando todos já tiverem escrito suas observações em seus cadernos, o professor inicia uma discussão com a sala toda para que sejam confrontados os pontos de vista de cada grupo. Embora muitas considerações relevantes possam aparecer nessa discussão, o professor não pode deixar de introduzir os conceitos de:

- manchete: frase de impacto, com letras maiores no topo da notícia, que resume a informação principal do texto;

- lead: quem, onde e quando aconteceu o que será contado;

- técnica da pirâmide invertida: inicia-se com o lead para depois contar o como e o porquê aquilo aconteceu;

- distanciamento jornalístico: não se fala em primeira pessoa, se conta o fato (OLIVEIRA, 1991).

\section{Comentários:}

Ainda que bastante longa, a realização da atividade lúdica com um suporte visual auxiliou nas associações lógicas feitas pelos alunos, de forma que facilitou a compreensão das características específicas do texto jornalístico.

As imagens escolhidas pela professora-pesquisadora foram: uma mãe com seus filhos no berço, uma criança na praia, uma estudante adolescente e um rapaz com uniforme de esporte. 


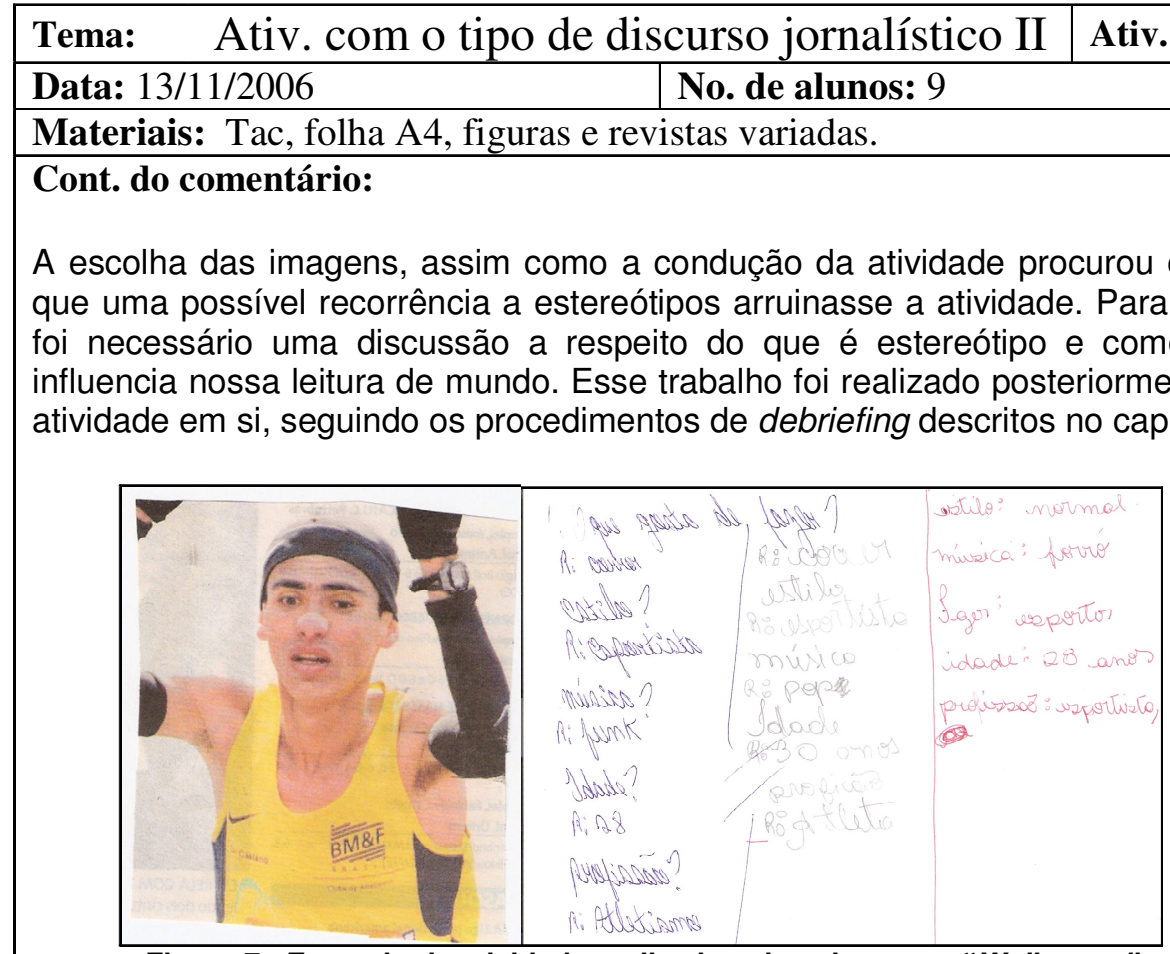

Figura 7 - Exemplo de atividade realizada pelos alunos no "Wall game"

Optou-se pelo trabalho apenas com a identificação do público-alvo, das peculiaridades do veículo e dos elementos distintivos do texto jornalístico (manchete, lead, técnica de pirâmide invertida e distanciamento objetivo do texto) por causa da restrição do tempo total do minicurso. A escolha dessas características como sendo as mais importantes foi baseada em Oliveira (1991).

Entre os aspectos que pareceram mais fáceis de serem compreendidos pelos alunos, a variação da linguagem foi certamente o que mais chamou atenção, já que a relacionaram com situações de seu próprio cotidiano. O conceito de manchete também já se encontrava amplamente difundido entre eles.

Entretanto, notou-se que a idéia de pirâmide invertida não ficou muito clara nesse momento para todos os alunos.

Objetivos do professor: aproveitar o conhecimento que os alunos têm sobre as características específicas do texto jornalístico para aprofundá-lo, de maneira que seja possível, nas etapas posteriores, que esses alunos escrevam textos nesse gênero.

Objetivos do aluno: relacionar o conhecimento de mundo que já possui sobre as características específicas do texto jornalístico às considerações feitas pelo professor e pelo grupo sobre esse assunto.

Conhecimento mobilizado: lingüístico (GRAMÁTICA 1). 


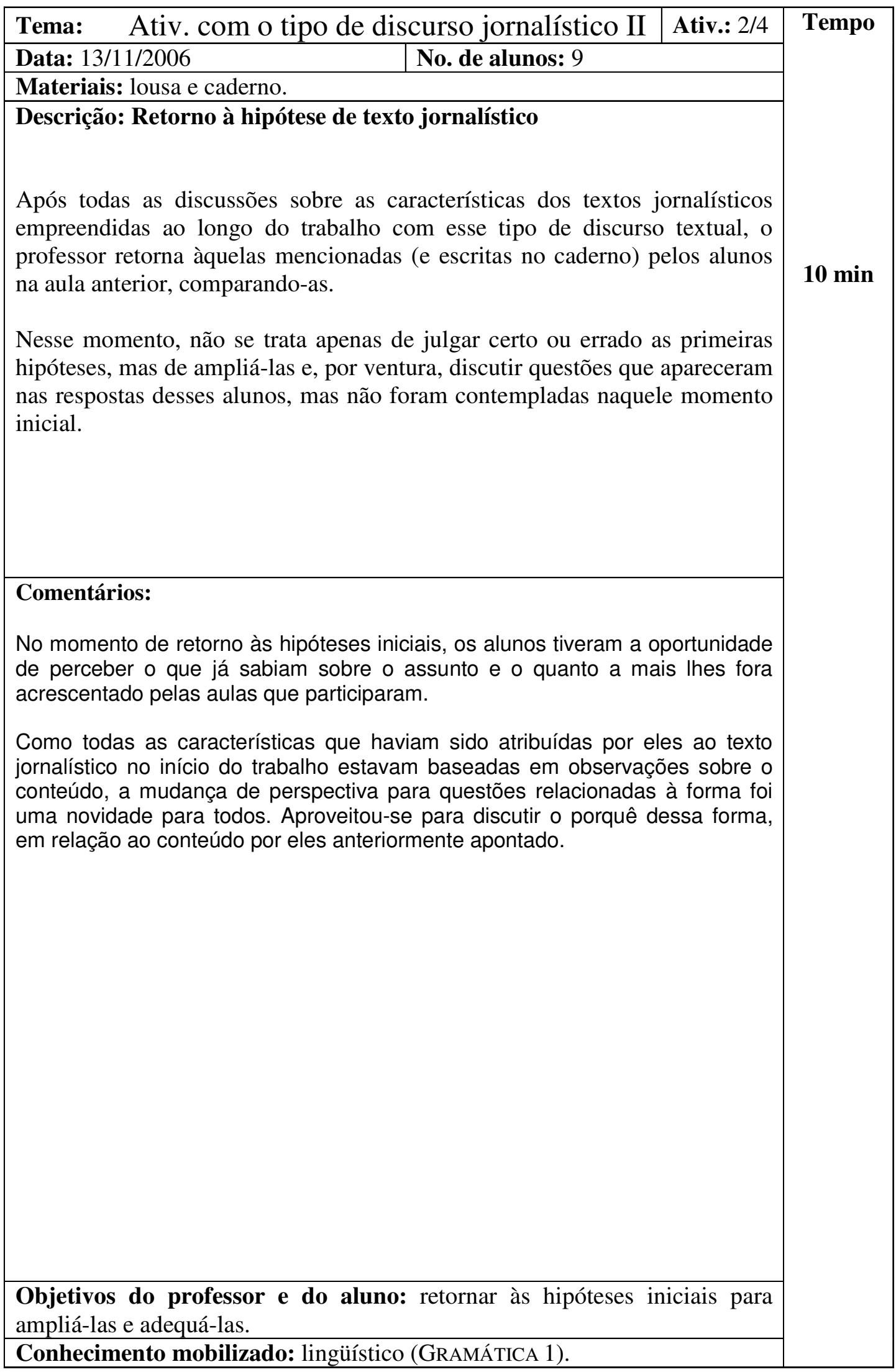




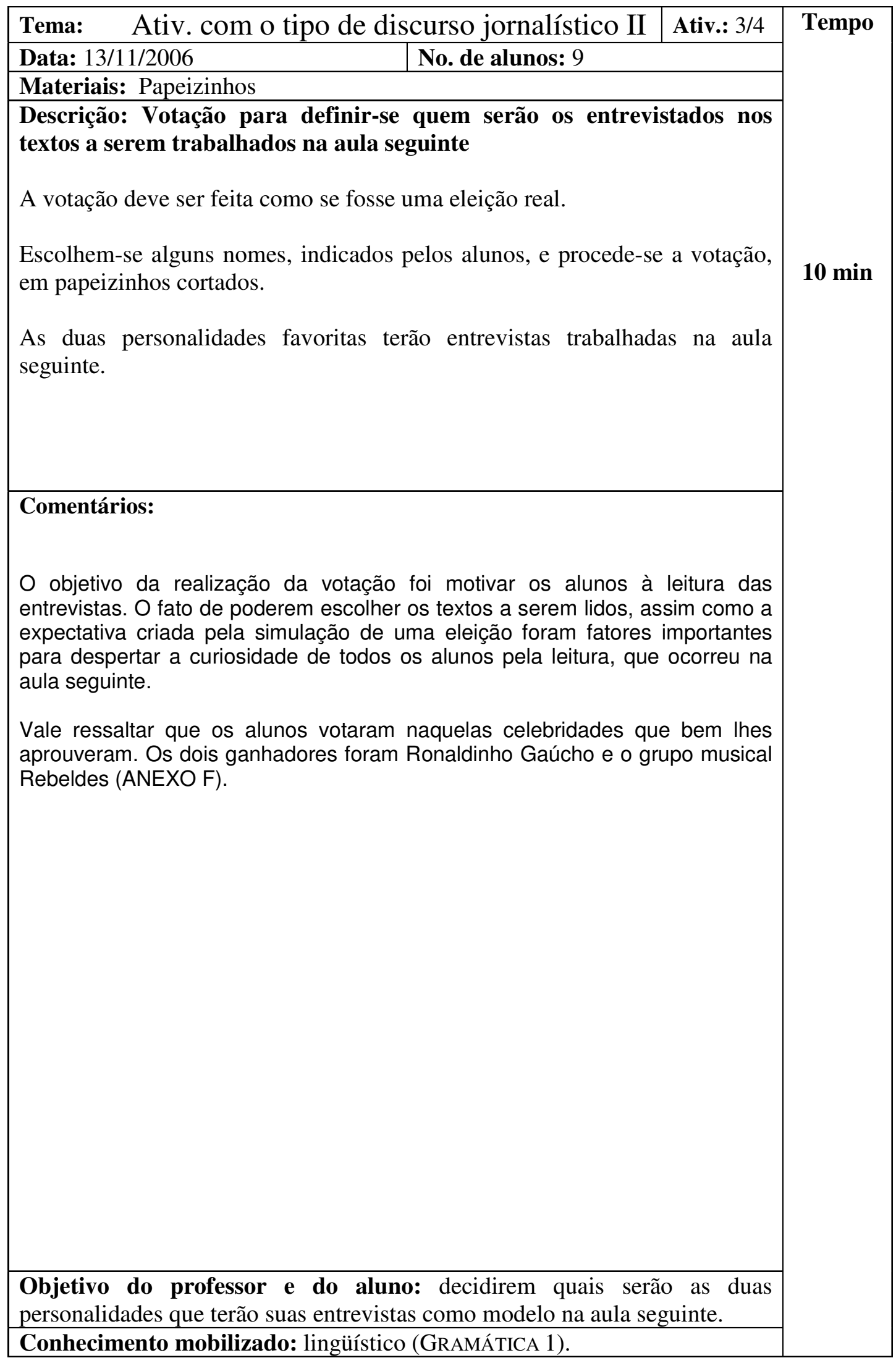




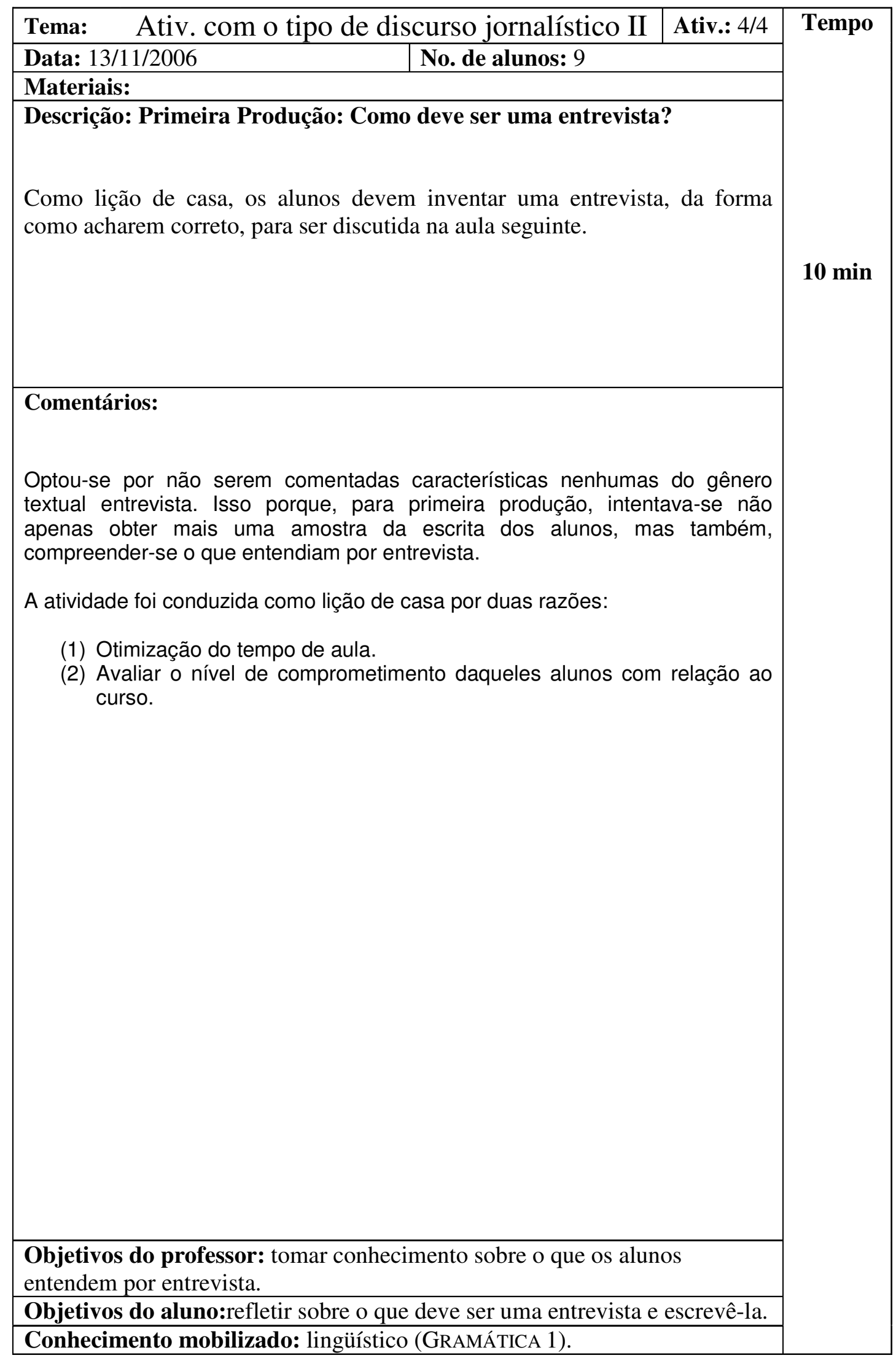




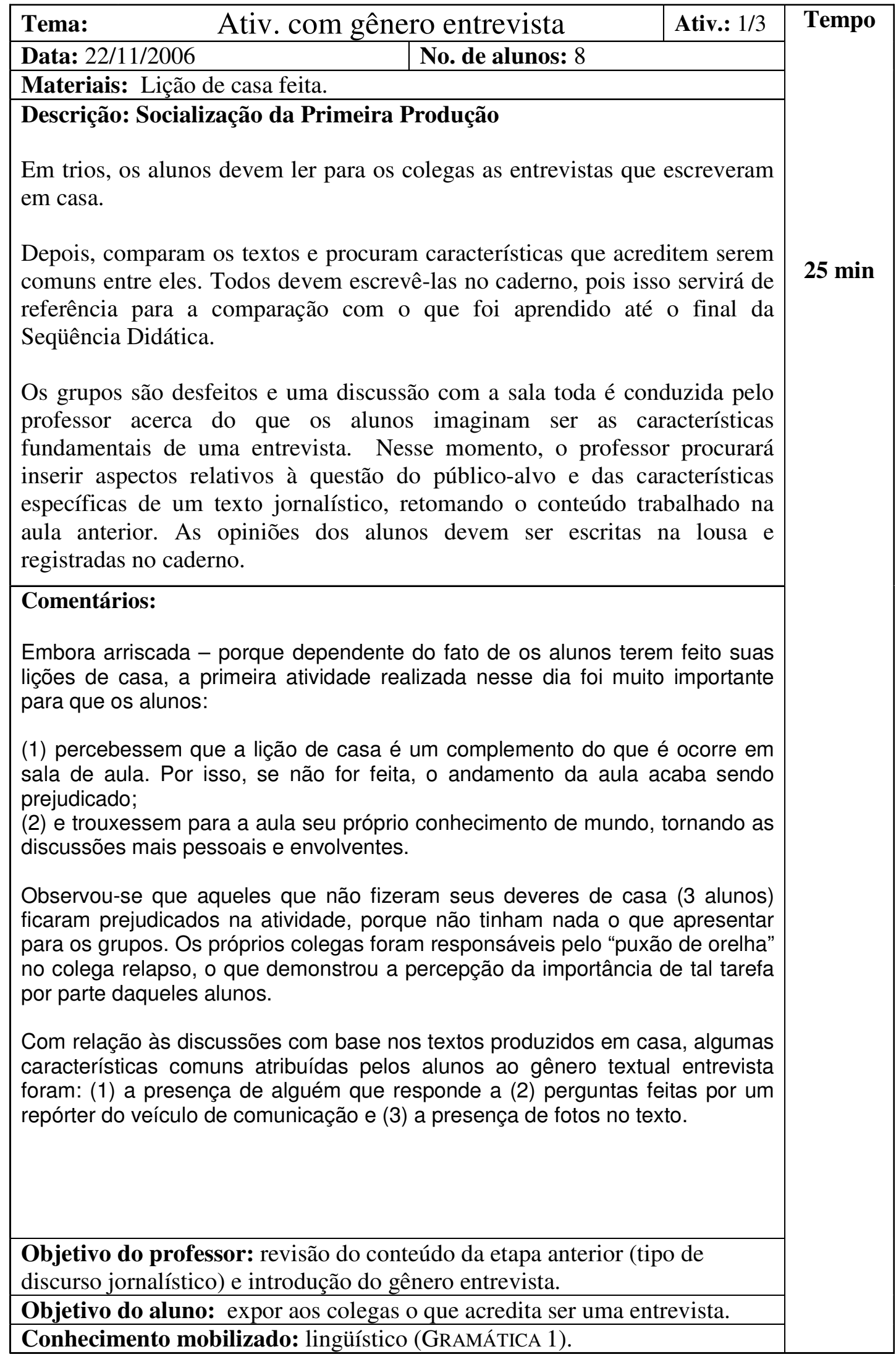




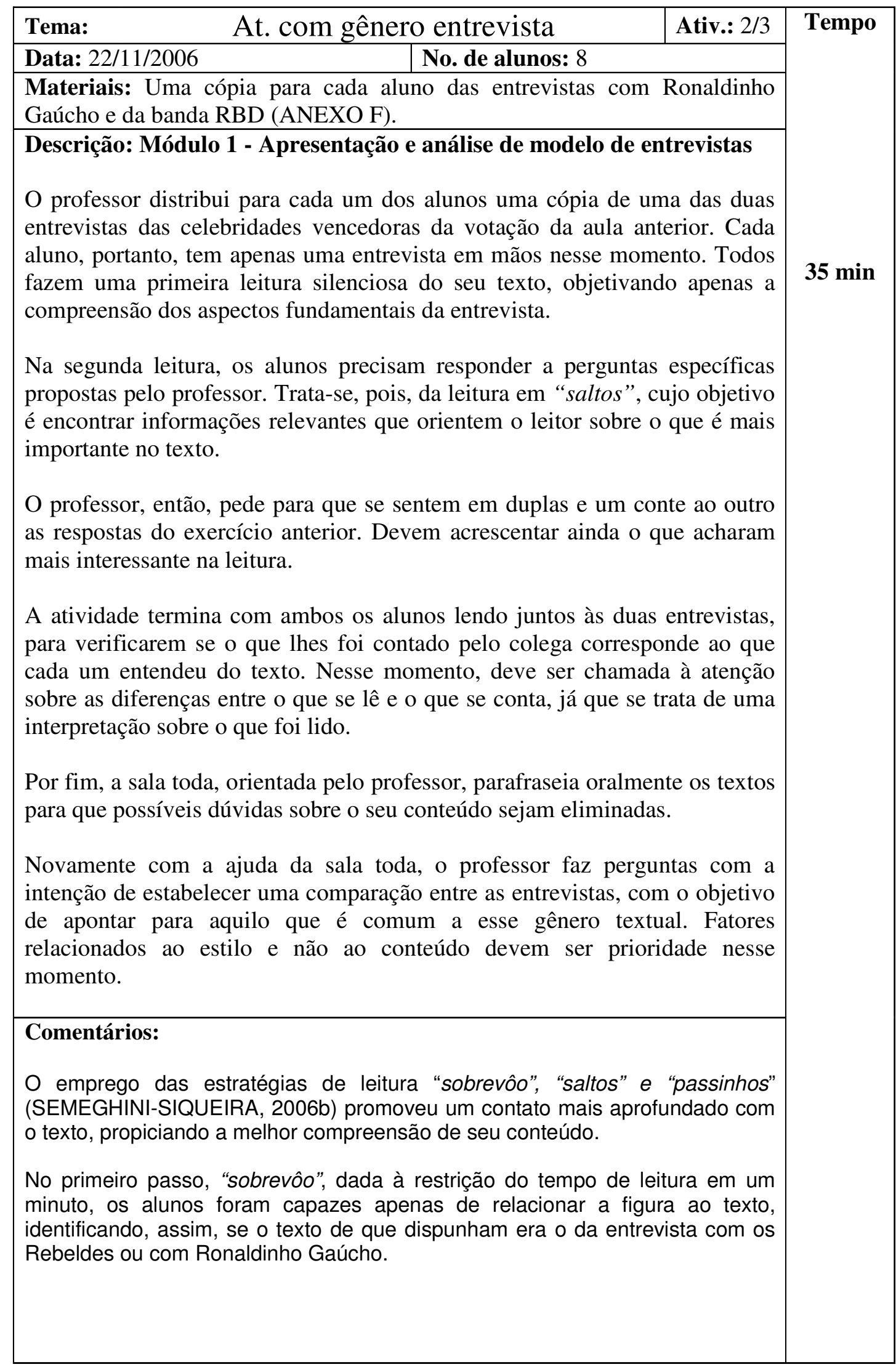




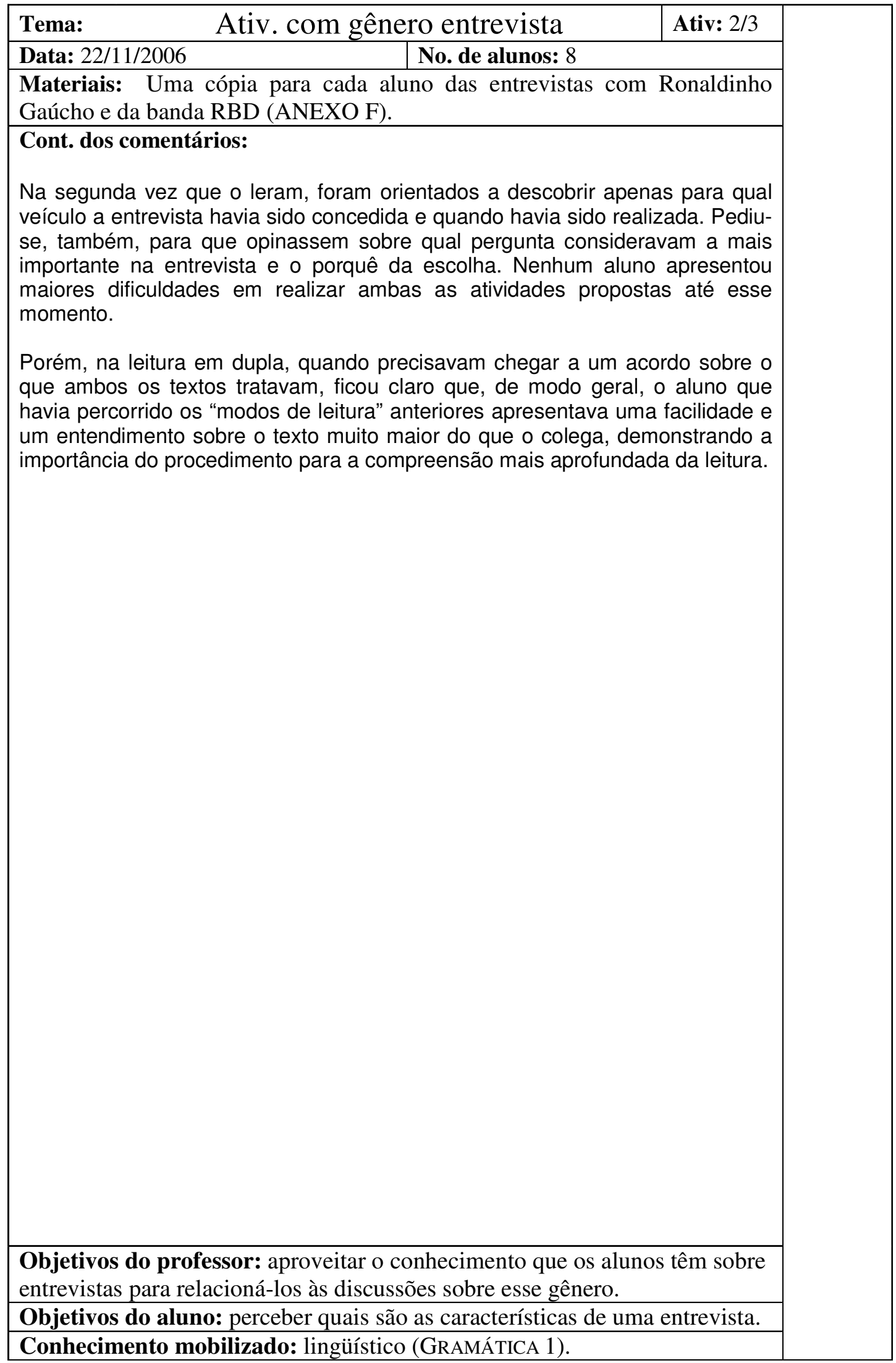




\begin{tabular}{|c|c|c|c|}
\hline Tema: & ro entrevista & Aula: $3 / 3$ & \multirow[t]{8}{*}{ Tempo } \\
\hline Data: 2 & No. de alunos: & & \\
\hline \multicolumn{3}{|c|}{ Materiais: caderno. } & \\
\hline \multicolumn{3}{|c|}{$\begin{array}{l}\text { Descrição: Módulo } 2 \text { - Teste de modelo (escrita coletiva) } \\
\text { Técnica do teatro (REIMES, 1983, p. 73-74). }\end{array}$} & \\
\hline \multicolumn{3}{|c|}{$\begin{array}{l}\text { Um aluno na sala se dispõe a ser entrevistado. Essa pessoa faz de conta que é } \\
\text { alguém famoso. Todos os alunos podem ser entrevistadores, mas, em um } \\
\text { primeiro momento, apenas um aluno pode ser o entrevistado e um outro, o } \\
\text { "gravador," isto é, quem anota as respostas. Todos os demais são repórteres. }\end{array}$} & \\
\hline \multicolumn{3}{|c|}{$\begin{array}{l}\text { Assim que esse aluno termina de dar a entrevista, os entrevistadores e o } \\
\text { entrevistado também anotam o que lembram das respostas. A classe compara } \\
\text { suas respostas coletivamente com as que o "gravador" transcreveu. }\end{array}$} & \\
\hline \multicolumn{3}{|c|}{$\begin{array}{l}\text { Isso é feito para que os alunos percebam a discrepância nas versões daquilo } \\
\text { que foi registrado pela memória de cada um e percebam a diferença entre as } \\
\text { entrevistas transcritas diretamente e as que passam pela re-elaboração do } \\
\text { jornalista. }\end{array}$} & \\
\hline \multicolumn{3}{|c|}{$\begin{array}{l}\text { Outra pessoa posteriormente torna-se o entrevistado e, desta vez, todos são } \\
\text { "gravadores". Os textos obtidos diretamente do entrevistado são re- } \\
\text { elaborados para a forma indireta pelos alunos. }\end{array}$} & \\
\hline \multicolumn{3}{|c|}{$\begin{array}{l}\text { A princípio, ninguém queria ser entrevistado, mas, depois de uma primeira } \\
\text { "rodada" de perguntas com uma voluntária, todos queriam ocupar essa } \\
\text { posição. Por uma questão de tempo, apenas mais uma outra aluna, escolhida } \\
\text { no "dois ou um", foi entrevistada. A posição de "gravador" foi a menos popular } \\
\text { entre os alunos, pois necessitava de agilidade na escrita, o que não era de } \\
\text { domínio de todos. A participação nas perguntas foi unânime. }\end{array}$} & \\
\hline \multicolumn{3}{|c|}{$\begin{array}{l}\text { Além de servir como uma experiência controlada de execução de entrevista, } \\
\text { essa tarefa teve o objetivo de levar aos alunos à conscientização de que (1) } \\
\text { nem tudo que é dito deve (ou pode) se transcrito para uma entrevista, e (2) a } \\
\text { opção por se escrever uma entrevista direta ou indireta modifica também } \\
\text { diversos aspectos de sua elaboração, passando por questões como uso do } \\
\text { tempo verbal, necessidade de aspas para falas atuais e emprego de paráfrases } \\
\text { de tal forma que haja fidelidade ao que o entrevistado disse. }\end{array}$} & \\
\hline \multicolumn{3}{|c|}{$\begin{array}{l}\text { Objetivos do professor: oportunizar, de forma lúdica, a reflexão sobre } \\
\text { características específicas do gênero entrevista. }\end{array}$} & \\
\hline \multicolumn{3}{|c|}{ Objetivos do aluno: perceber quais são as características de uma entrevista. } & \\
\hline
\end{tabular}




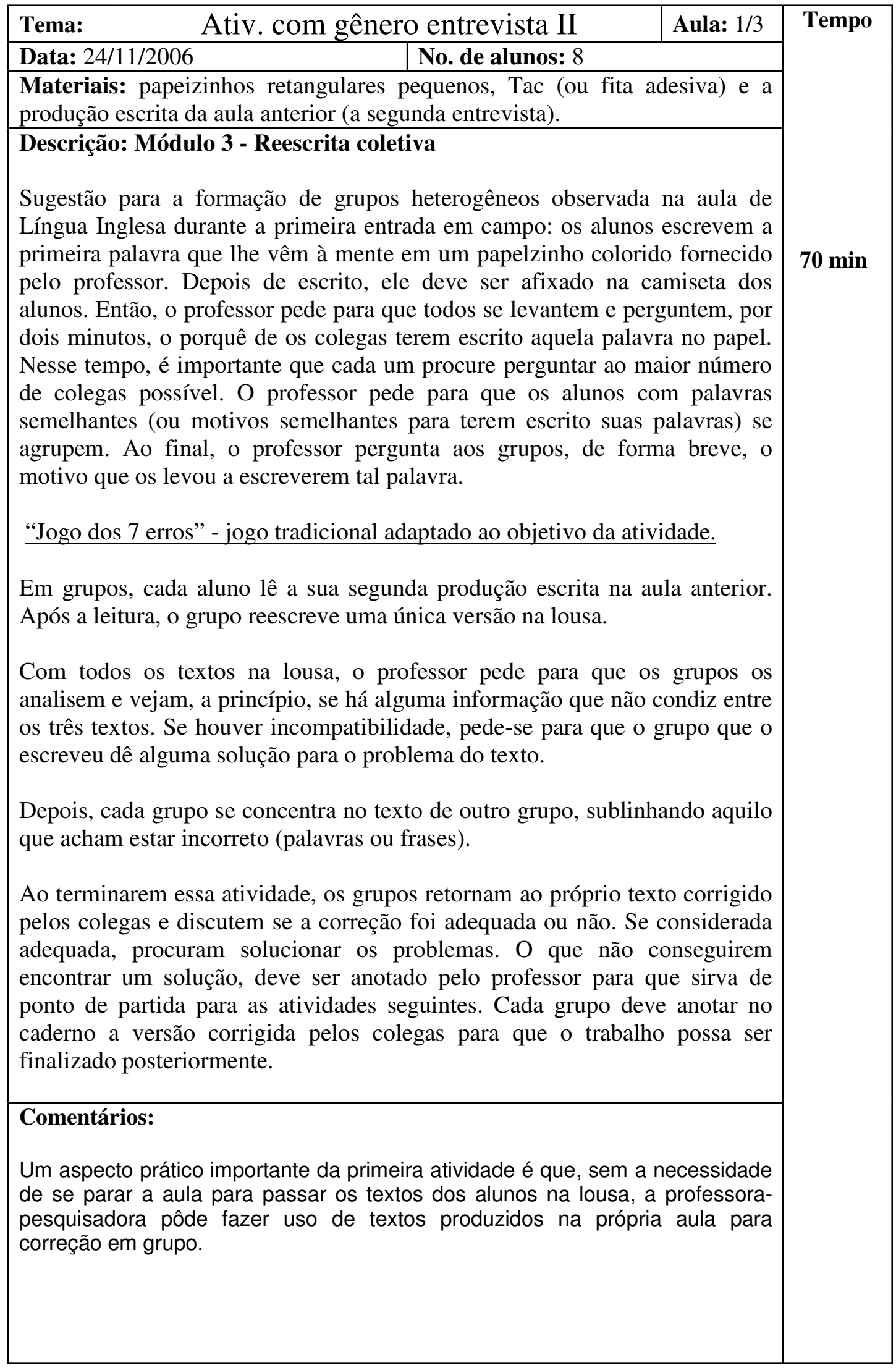




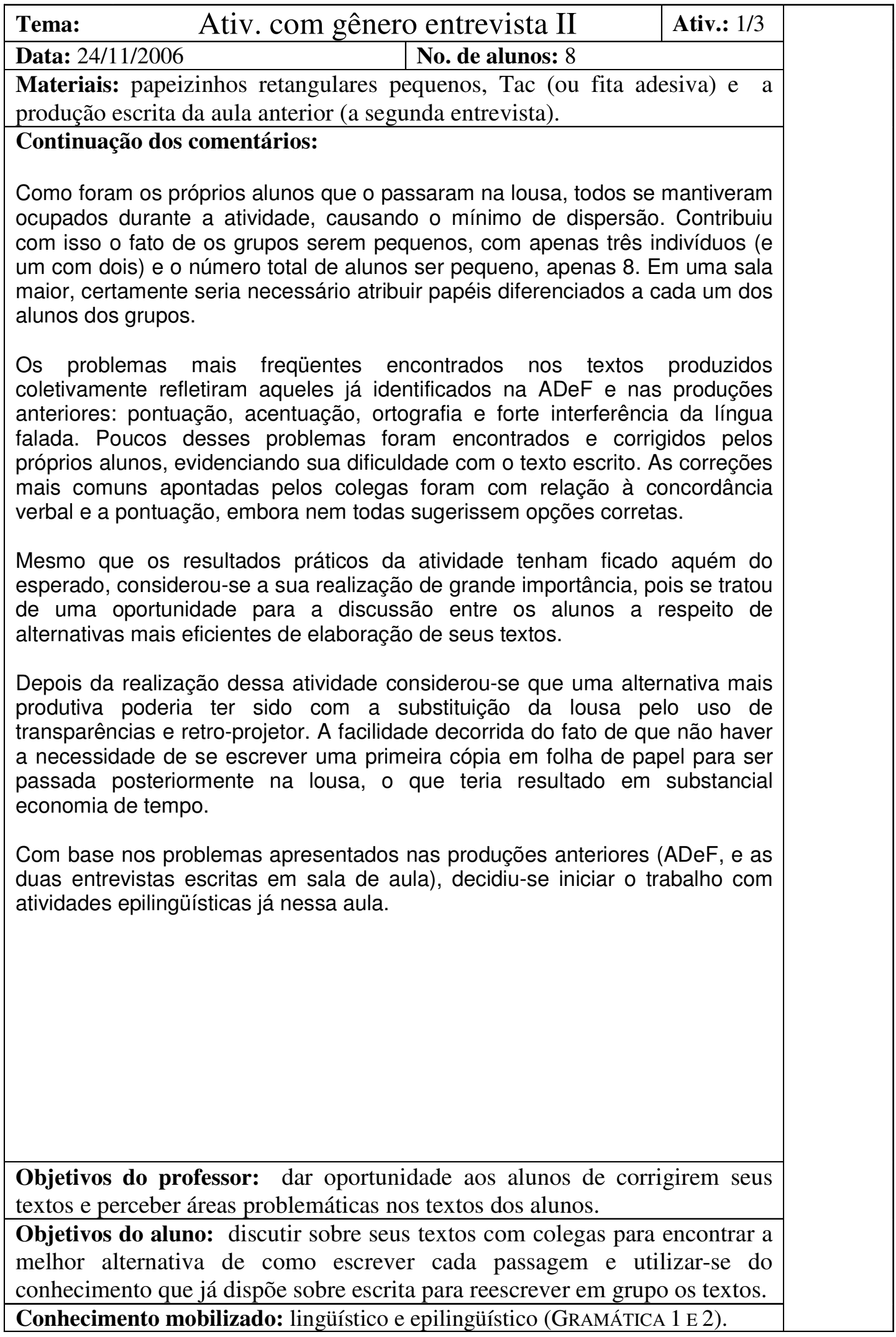




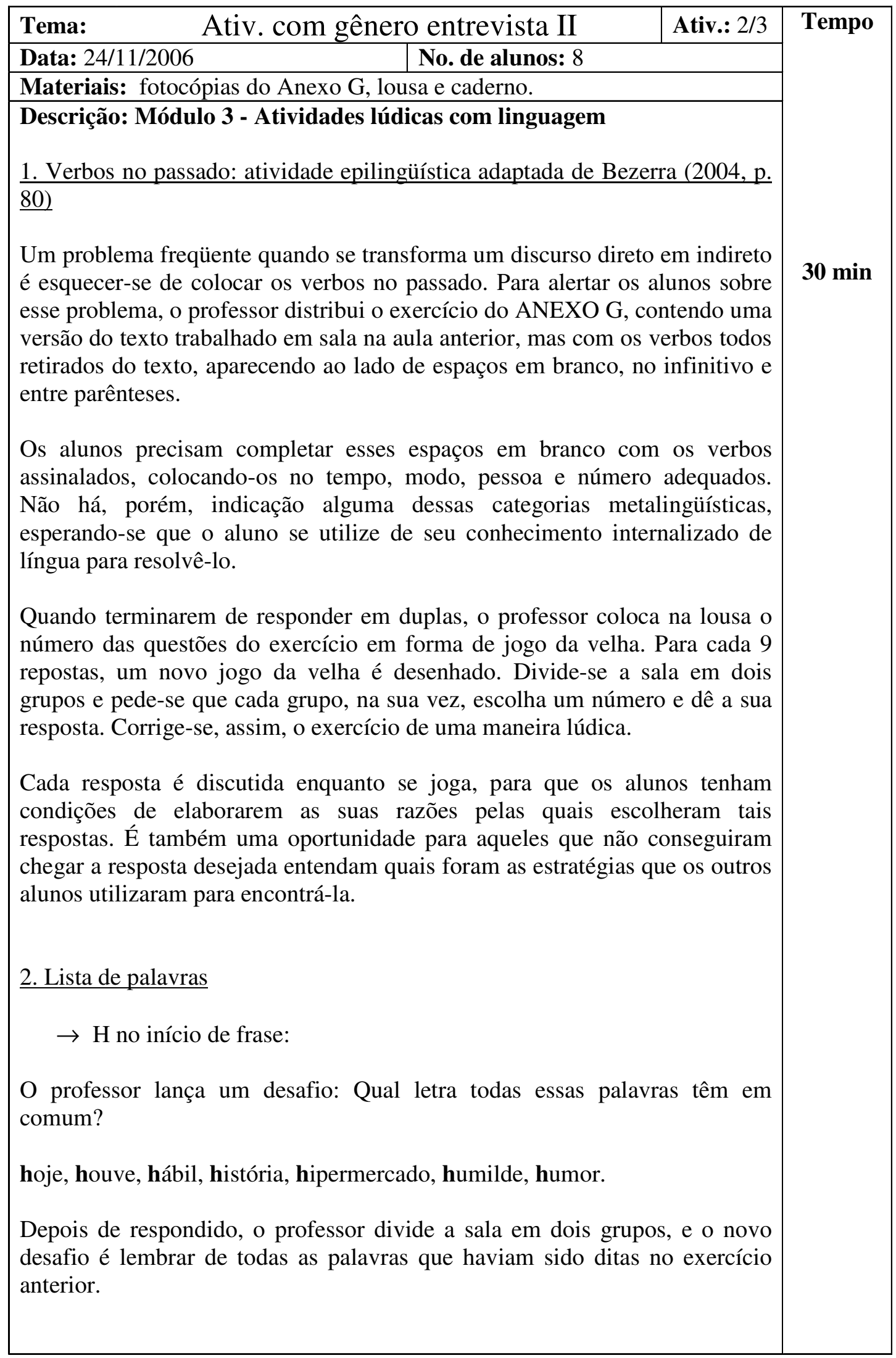




\begin{tabular}{|c|c|c|}
\hline Tema: & o entrevista II & Ativ.: $2 / 3$ \\
\hline Data: $24 / 11 / 2006$ & \multicolumn{2}{|l|}{ No. de alunos: 8} \\
\hline \multicolumn{3}{|c|}{ Materiais: fotocópias do ANEXO G, lousa e caderno. } \\
\hline \multicolumn{3}{|c|}{ Continuação da descrição: } \\
\hline \multicolumn{3}{|c|}{$\begin{array}{l}\text { Quando essas palavras tiverem sido esgotadas, os grupos passam a inclui } \\
\text { palavras que também contenham a letra H no início, mas não tinham side } \\
\text { mencionadas pelo professor. Todas as palavras são escritas na lousa, com } \\
\text { intuito de contar "pontos" para o grupo que mencionar palavra } \\
\text { corretamente. }\end{array}$} \\
\hline
\end{tabular}

Ao final de algum tempo - tanto pode ser quando os alunos não conseguirem mais lembrar de nenhum exemplo, ou quando o jogo começa a perder o seu interesse - o professor pede para que eles copiem no caderno as palavras relacionadas.

$\rightarrow \mathrm{O}$ jogo se repete idêntico, mas com a letra $\mathrm{C}$, nas palavras:

Em cima, certo, relacionamento, cantora, cipó, cenoura.

\section{Comentários:}

Na primeira atividade, muitos alunos foram capazes de chegar a concordância verbal correta. $O$ fato desses textos já terem sido trabalhados em aulas anteriores contribuiu para que os alunos fossem bem sucedidos, mas não a impediu de representar um desafio. O principal objetivo dessa atividade, portanto, não foi a identificação da resposta correta, mas a experimentação com a linguagem.

No jogo seguinte, o trabalho com a ortografia foi aliado à fixação da forma correta, auxiliada por procedimentos de disguised drills (repetição oral e escrita reiterada). Observou-se que:

- o interesse foi grande e a movimentação da sala também;

- se, a princípio, o foco das atividades era a competição, a necessidade de concentração e de raciocínio fez com que os alunos buscassem "aliados" entre os colegas, remodelando seus grupos a cada atividade;

- a variedade de padrões de interação (trabalho em duplas, em grupos, individualmente) ajudou na dinâmica da aula;

- a variedade de atividades fez com que não houvesse praticamente dispersão alguma.

Objetivos do professor: exercitar/resolver alguns dos problemas específicos da escrita dos alunos.

Objetivos do aluno: fazer associações de regras e palavras que já conhece a grafia correta com aquelas em que houve problema em exercícios anteriores.

Conhecimento mobilizado: epilingüístico (GRAMÁTICA 2). 


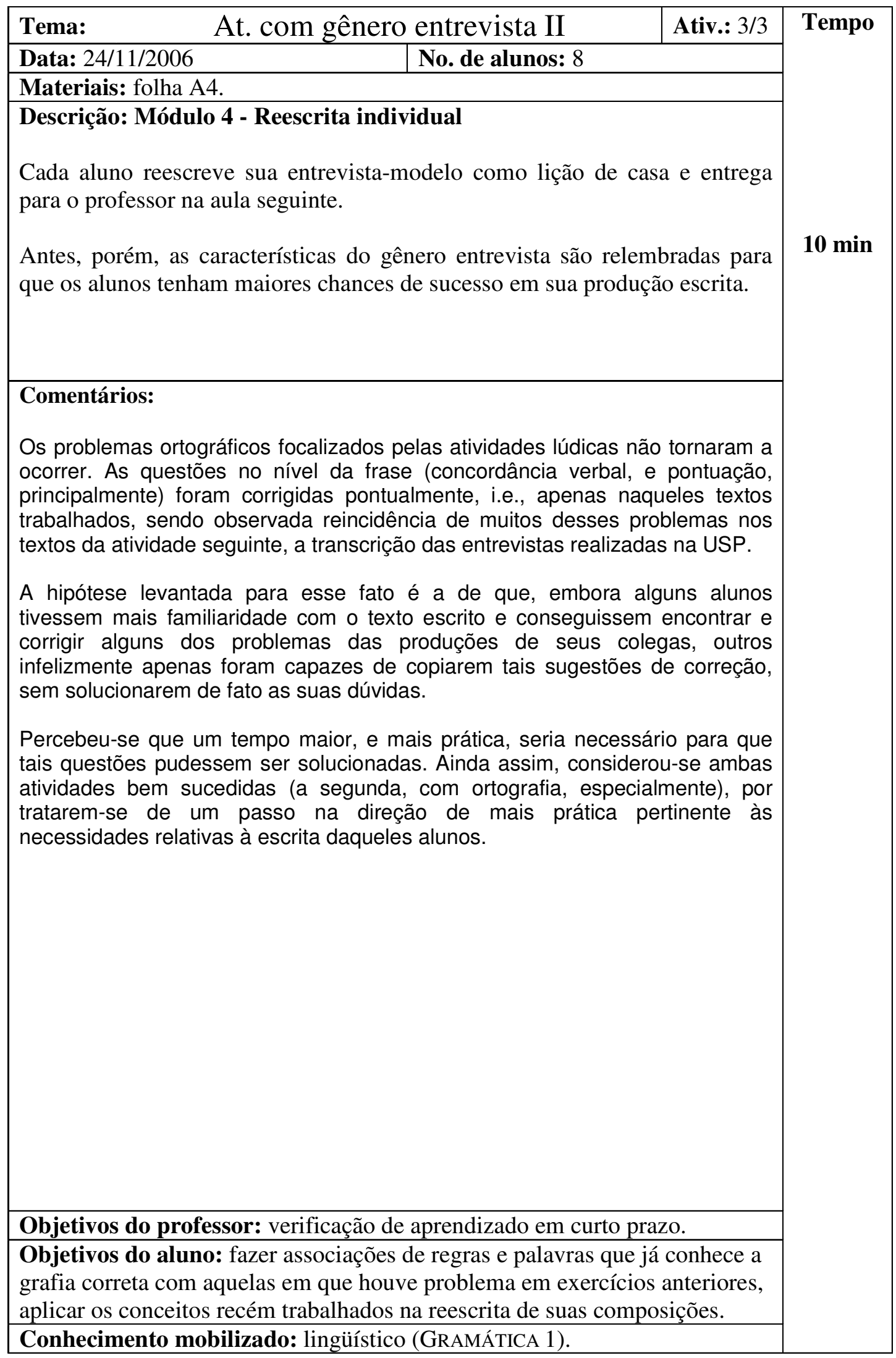




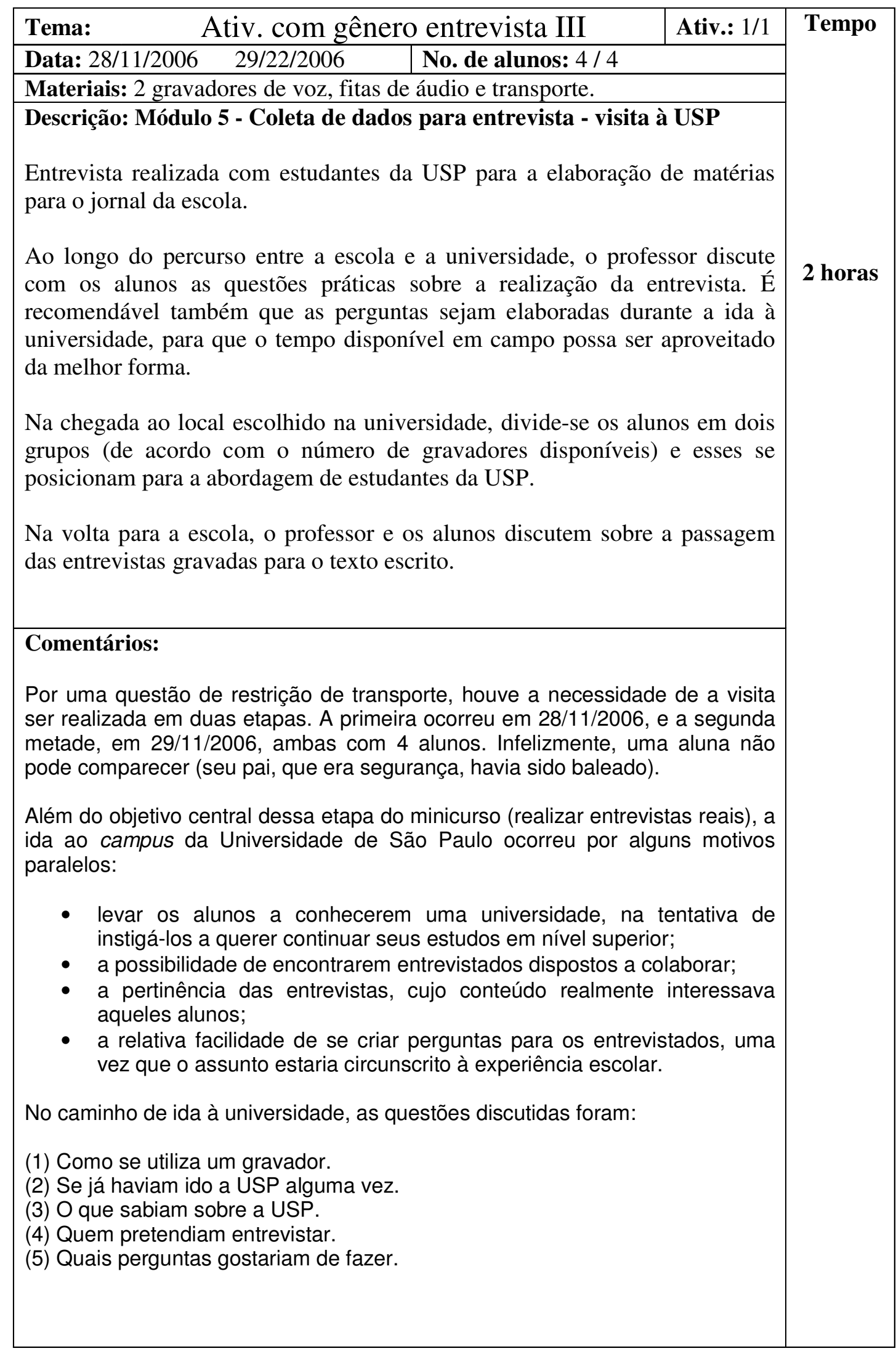




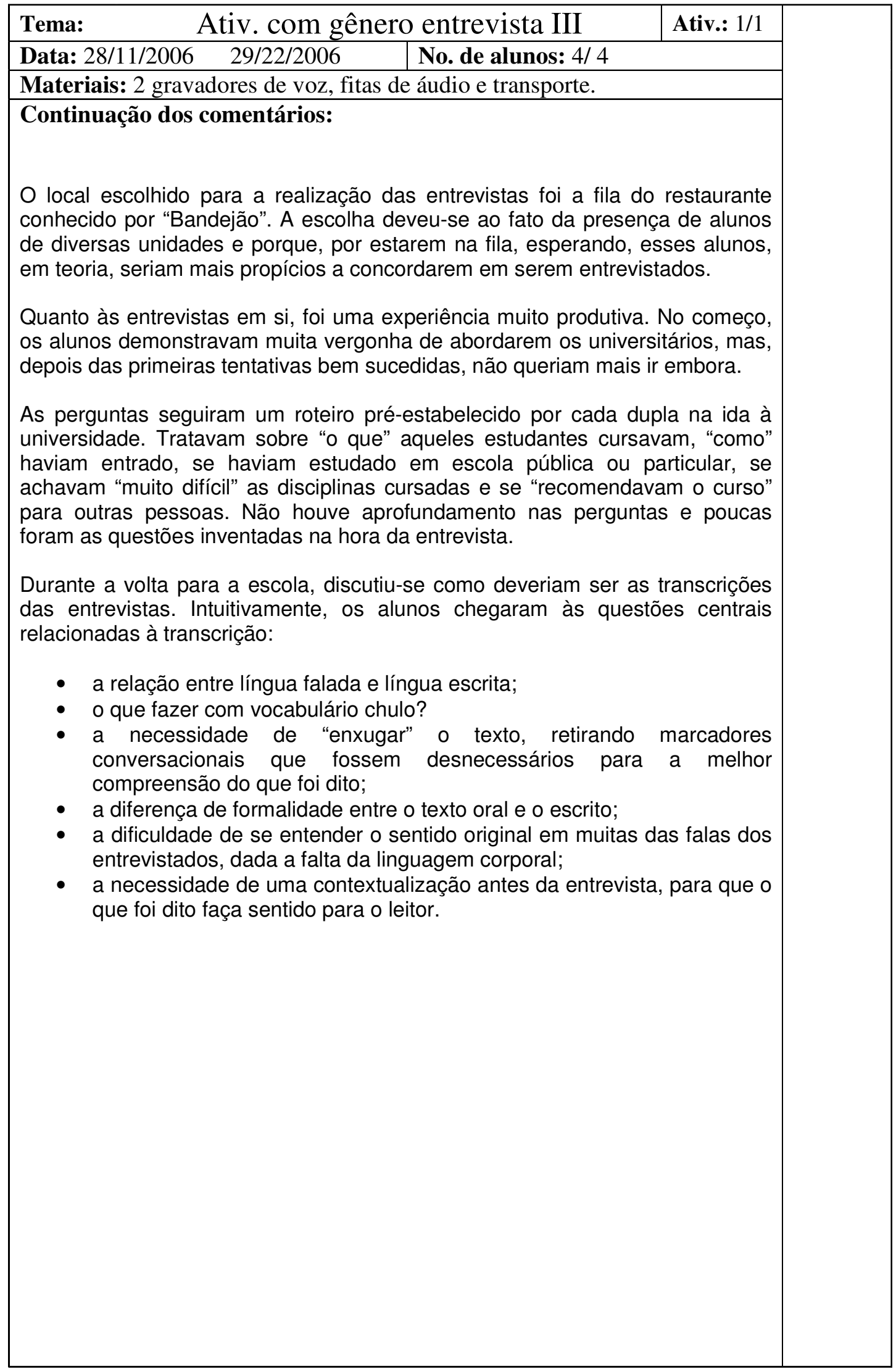




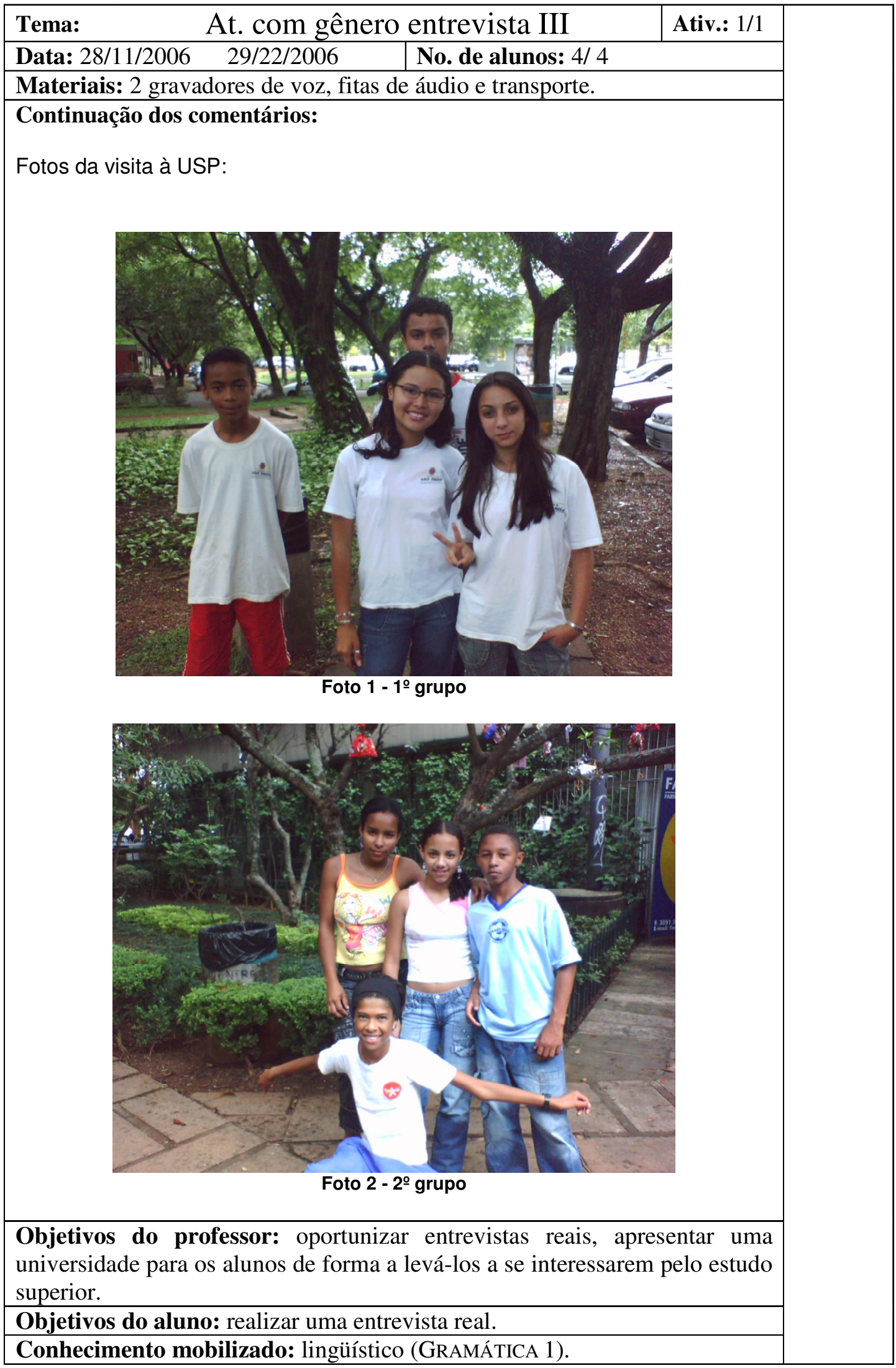




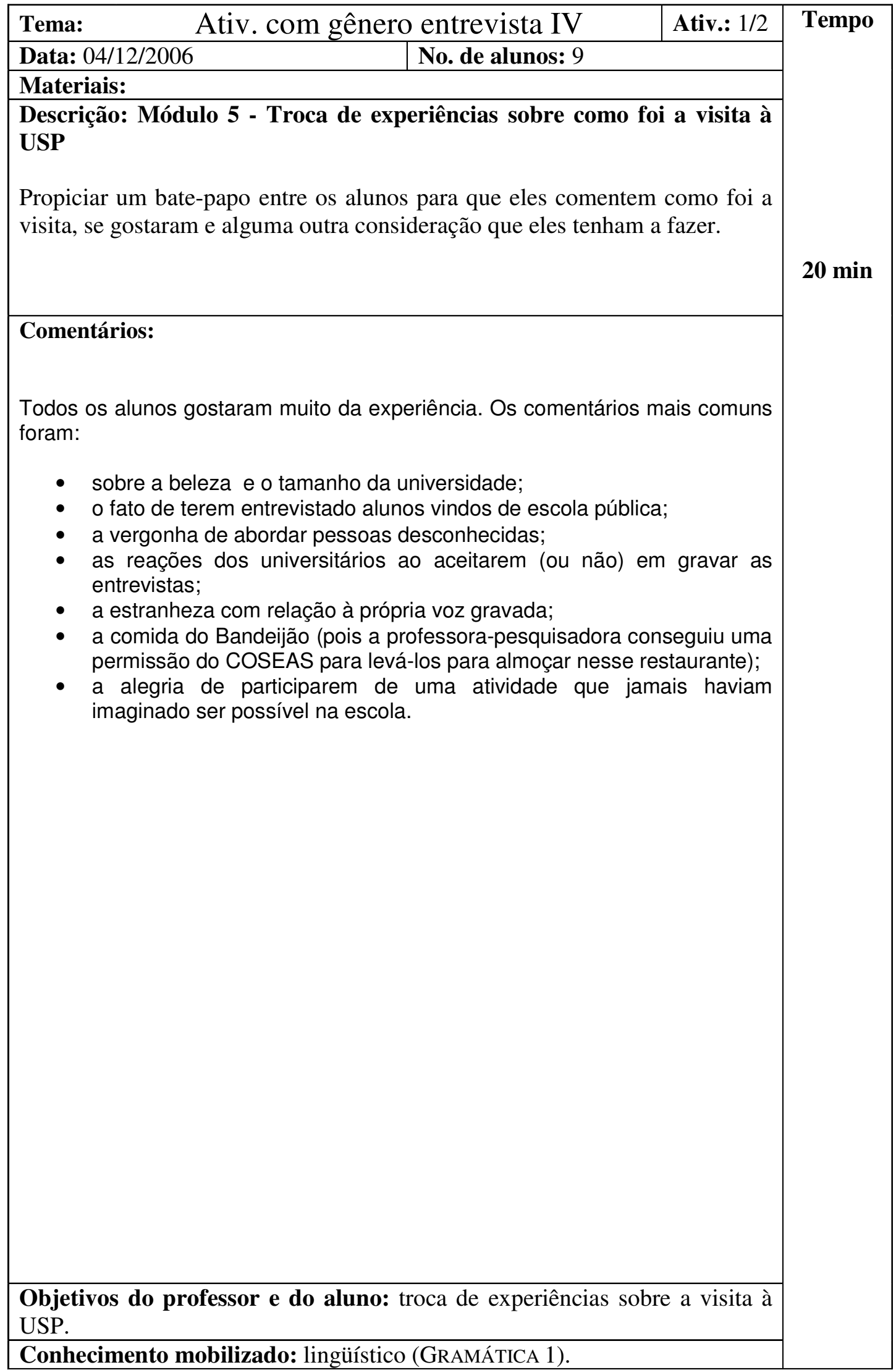




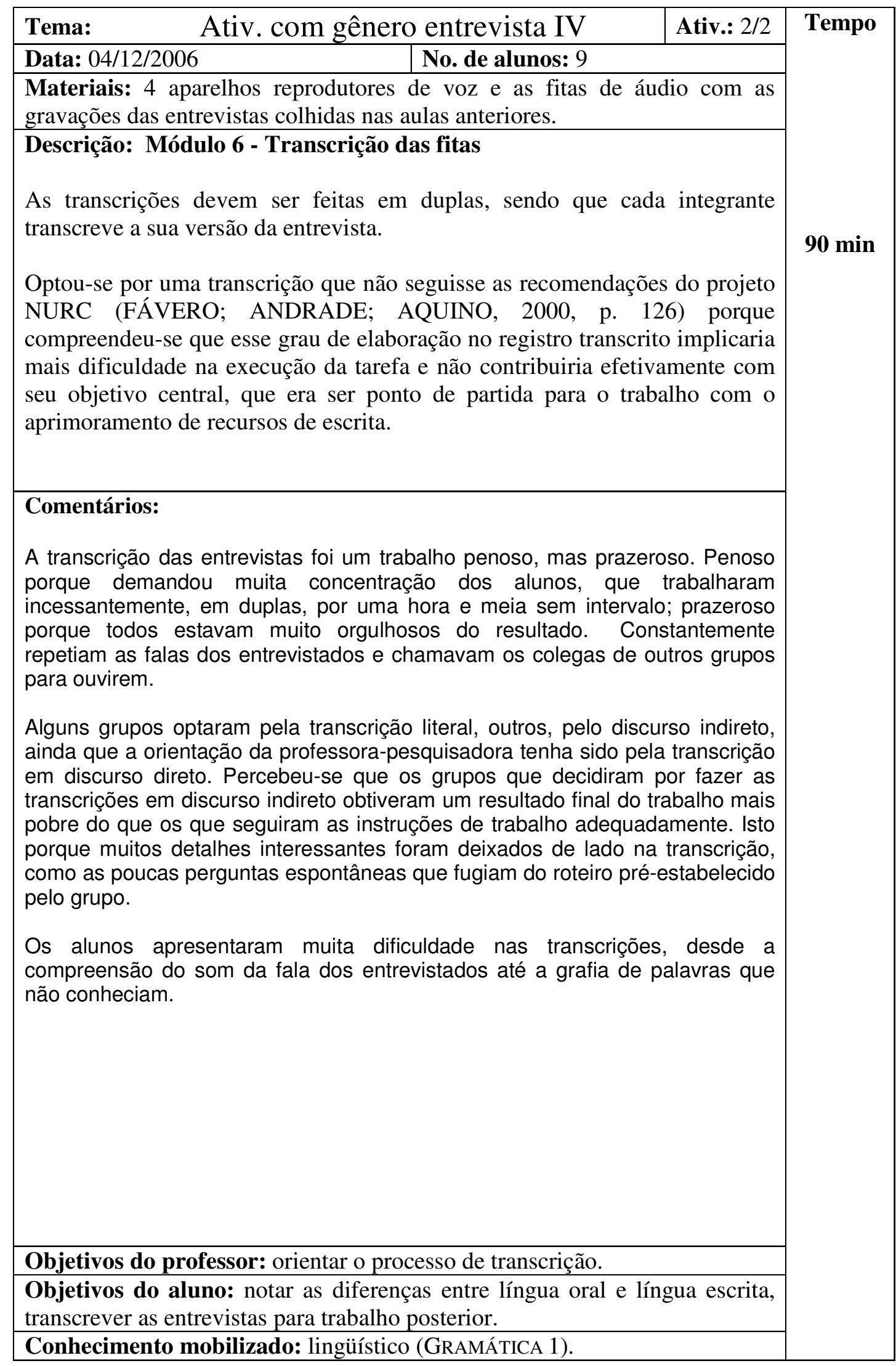




\begin{tabular}{|c|c|c|}
\hline \multicolumn{2}{|c|}{ Ativ. com gênero entrevista $\mathrm{V}$} & Ati \\
\hline Data: 05/12/2006 & No. de alunos: 9 & \\
\hline \multicolumn{3}{|c|}{ Materiais: fotocópias das transcrições digitadas para cada dupla e dicionário. } \\
\hline \multicolumn{3}{|c|}{ Descrição: Módulo 7 - Reescrita coletiva I - foco na ortografia } \\
\hline \multicolumn{3}{|c|}{$\begin{array}{l}\text { Com as entrevistas previamente digitadas (ANEXO H) pelo professor, os } \\
\text { alunos relêem suas transcrições para verificarem se há algum problema de } \\
\text { digitação nas cópias que lhes foram entregues. Os mesmos grupos que } \\
\text { trabalharam para fazer as entrevistas se reúnem para comparar as transcrições } \\
\text { digitadas de cada um do grupo. Sempre quando houver diferença de } \\
\text { ortografia os alunos são orientados a discutir para encontrar a forma que lhes } \\
\text { parece mais correta e consultar o dicionário. }\end{array}$} \\
\hline \multicolumn{3}{|l|}{ Comentários: } \\
\hline \multicolumn{3}{|c|}{$\begin{array}{l}\text { Há dois momentos bastante distintos nessa atividade: em uma primeira etapa, } \\
\text { os alunos necessitam desempenhar a função de revisores de texto, o que se } \\
\text { mostrou bastante difícil para uns; e uma segunda, na qual os problemas } \\
\text { encontrados nos textos dos colegas foram corrigidos coletivamente, por meio } \\
\text { do uso do dicionário. }\end{array}$} \\
\hline \multicolumn{3}{|c|}{$\begin{array}{l}\text { Aqueles cuja intimidade com a língua escrita era menor tiveram muita } \\
\text { dificuldade na primeira etapa. Percebeu-se a incerteza de pedirem ou não } \\
\text { ajuda aos colegas. Por esse motivo, preferiu-se que esse trabalho fosse } \\
\text { realizado em duplas e não individualmente, o que atenuou a percepção da } \\
\text { dificuldade, mas certamente não a sanou. Mesmo sendo muito produtiva, essa } \\
\text { estratégia necessita de alunos com um maior domínio da língua escrita. Os } \\
\text { exemplos de problemas por eles identificados foram: }\end{array}$} \\
\hline $\begin{array}{l}\text { 1. Familia } \\
\text { 2. Izigenti } \\
\text { 3. Desda, Deste, desde } \\
\text { 4. Sirugia } \\
\text { 5. Agenti } \\
\text { 6. Dinovo } \\
\text { 7. Obrigado (a) ? Brigado } \\
\text { 8. Espectativa }\end{array}$ & $\begin{array}{l}\text { 9. Feiz } \\
\text { 10. Facudade } \\
\text { 11. Conserteza } \\
\text { 12. Profisão } \\
\text { 13. Eu tive que } \epsilon \\
\text { 14. Cer professo } \\
\text { exigente } \\
\text { 15. Mais (no lug } \\
\text { 16. Abreviações }\end{array}$ & \\
\hline
\end{tabular}

Tabela 5 - Incorreções ortográficas concernentes à produção coletiva

Não houve a pretensão de sanar todos os problemas lingüísticos desses alunos, por saber que isso só é possível apenas com um contato infinitamente mais prolongado do que aquele que foi proporcionado pelo minicurso em questão. Ainda assim, essa atividade possibilitou: (1) a chance de cada um, naquilo que sabia, procurar auxiliar o colega, (2) ler o texto do colega e, a partir daí, ter uma referência sobre o seu próprio texto e (3) exercitar, de forma contextualizada, o conteúdo aprendido.

Objetivos do professor: proporcionar estratégias eficientes de reescrita.

Objetivos do aluno: reescrever seu texto de uma forma prazerosa, utilizar dos conhecimentos já aprendidos da língua pra corrigir os textos dos colegas. Conhecimento mobilizado: lingüístico e epilingüístico (GRAMÁTICA 1 E 2). 


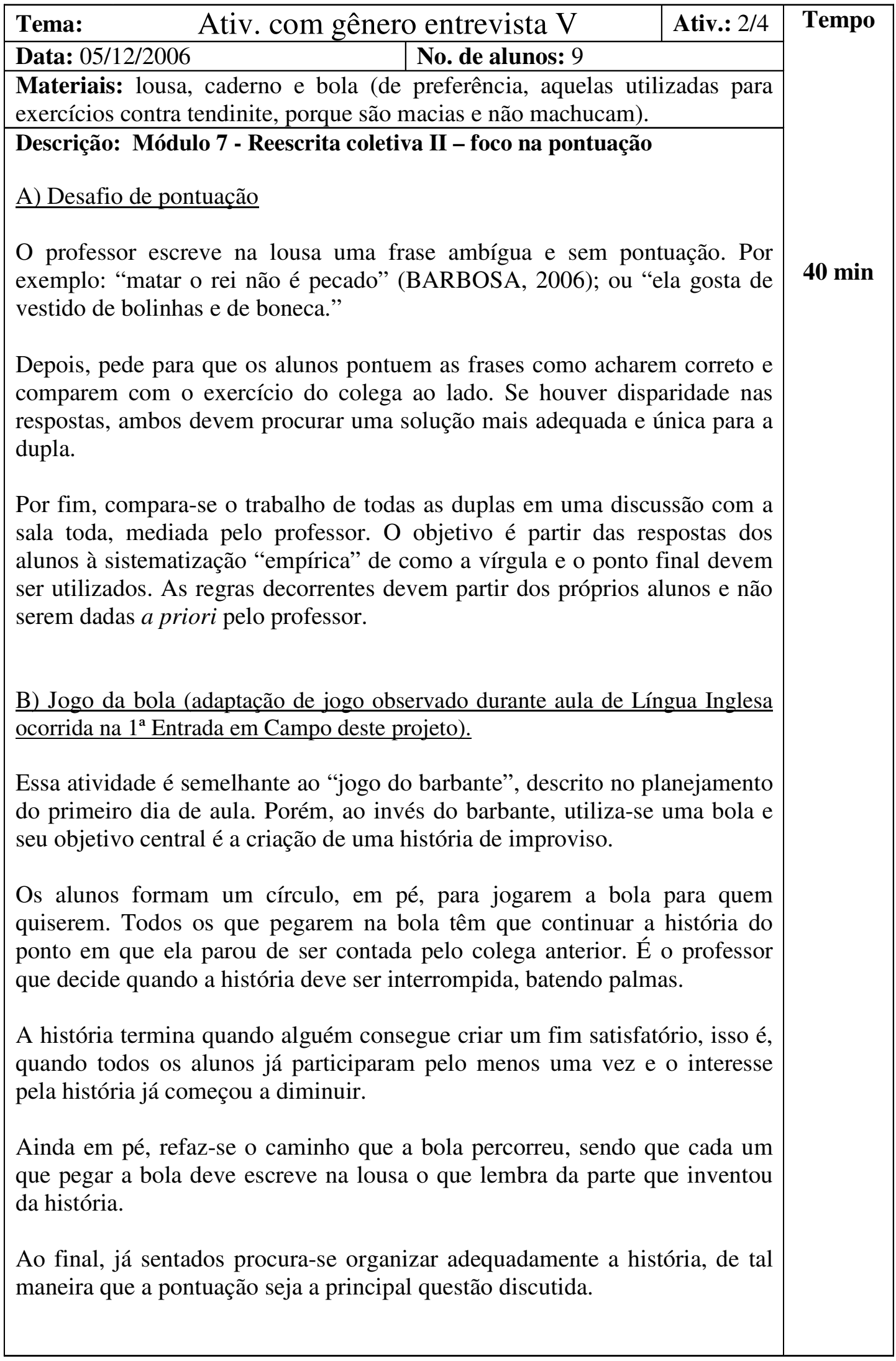




\begin{tabular}{|c|c|c|c|}
\hline \multicolumn{4}{|c|}{ Ativ. com gênero entrevista $\mathrm{V}$} \\
\hline \multicolumn{4}{|l|}{ Data: $05 / 12 / 2006$} \\
\hline \multicolumn{4}{|c|}{ Materiais: lousa e caderno. } \\
\hline \multicolumn{4}{|c|}{ Descrição: Módulo 7 - Reescrita coletiva III - foco na acentuação } \\
\hline \multicolumn{4}{|c|}{ Odd man out (WRIGHT, BETTERIDGE, BUCKBY, 1993, p. 122) } \\
\hline \multicolumn{4}{|c|}{ O professor escreve na lousa as palavras (dispostas em colunas): } \\
\hline Clínica & Aí & Fácil & São \\
\hline Pública & Você & Difícil & Gostarão \\
\hline Área & É & Família & Gostaram \\
\hline Música & Né & Está & Então \\
\hline Alguém & Só & Apóiam & Não \\
\hline
\end{tabular}

Figura 8 - At. epilingüística de acentuação

Os alunos, individualmente, precisam identificar qual é a semelhança entre elas e qual é aquela que não segue a característica comum às demais. Essa palavra diferente deve ser circulada.

Em pares, eles se unem para, então, discutirem o porquê acreditam que as palavras circuladas são diferentes das demais e elaboram "regras" para cada uma.

O professor deve, ao final desse processo, confrontar as hipóteses de cada grupo, e decidir, com a sala, pelas melhores explicações, que serão anotadas por todos - assim como as próprias palavras.

\section{Comentários:}

A primeira parte do exercício foi bem sucedida, pois os alunos identificaram com facilidade as palavras "diferentes".

A segunda metade, porém, provou ser mais difícil, dada a problemática da formulação de hipóteses para o fenômeno observado. Alguns alunos não sabiam o que é sílaba e optou-se pela não utilização de metalinguagem.

Falou-se em "parte pronunciada com mais força na palavra" e "brincou-se" com a mudança da tonalidade das sílabas para que percebessem como a palavra ficaria diferente se $\mathrm{o}$ acento incidisse em outra vogal.

Objetivos do professor: proporcionar estratégias eficientes de reescrita.

Objetivos do aluno: reescrever seu texto de uma forma prazerosa, utilizar dos conhecimentos já aprendidos da língua pra corrigir os textos dos colegas.

Conhecimento mobilizado: epilingüístico (GRAMÁTICA 2). 


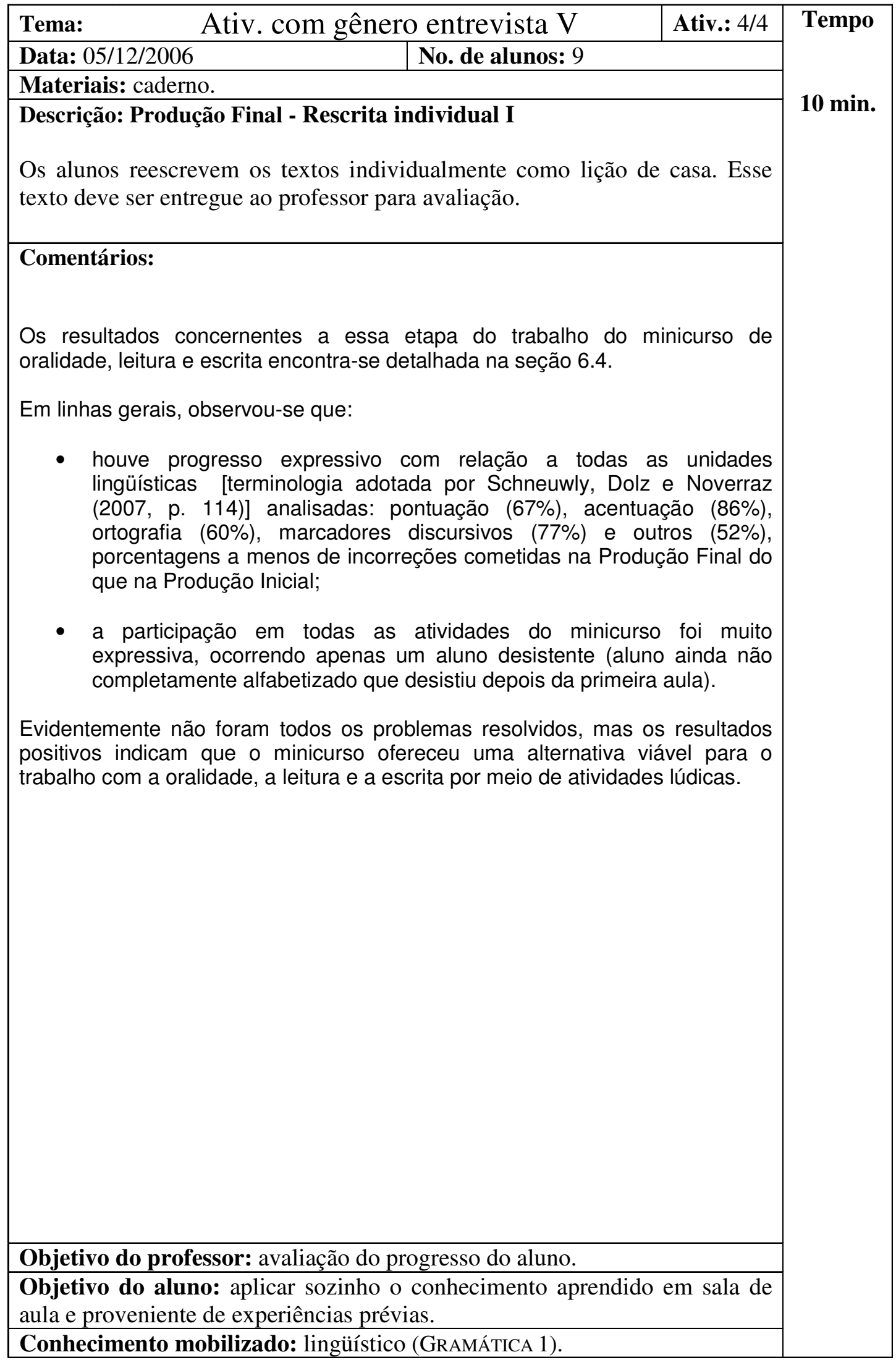




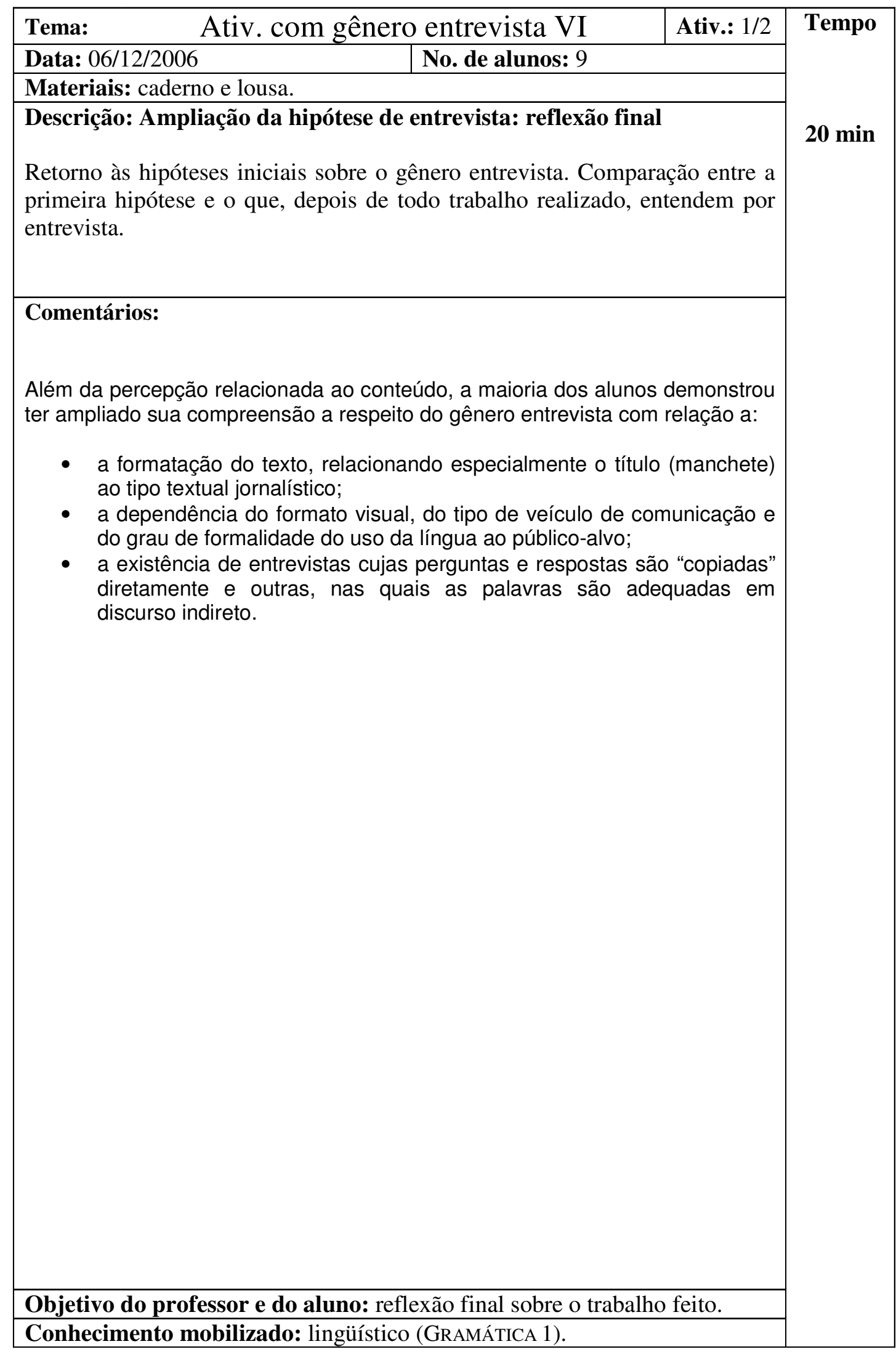




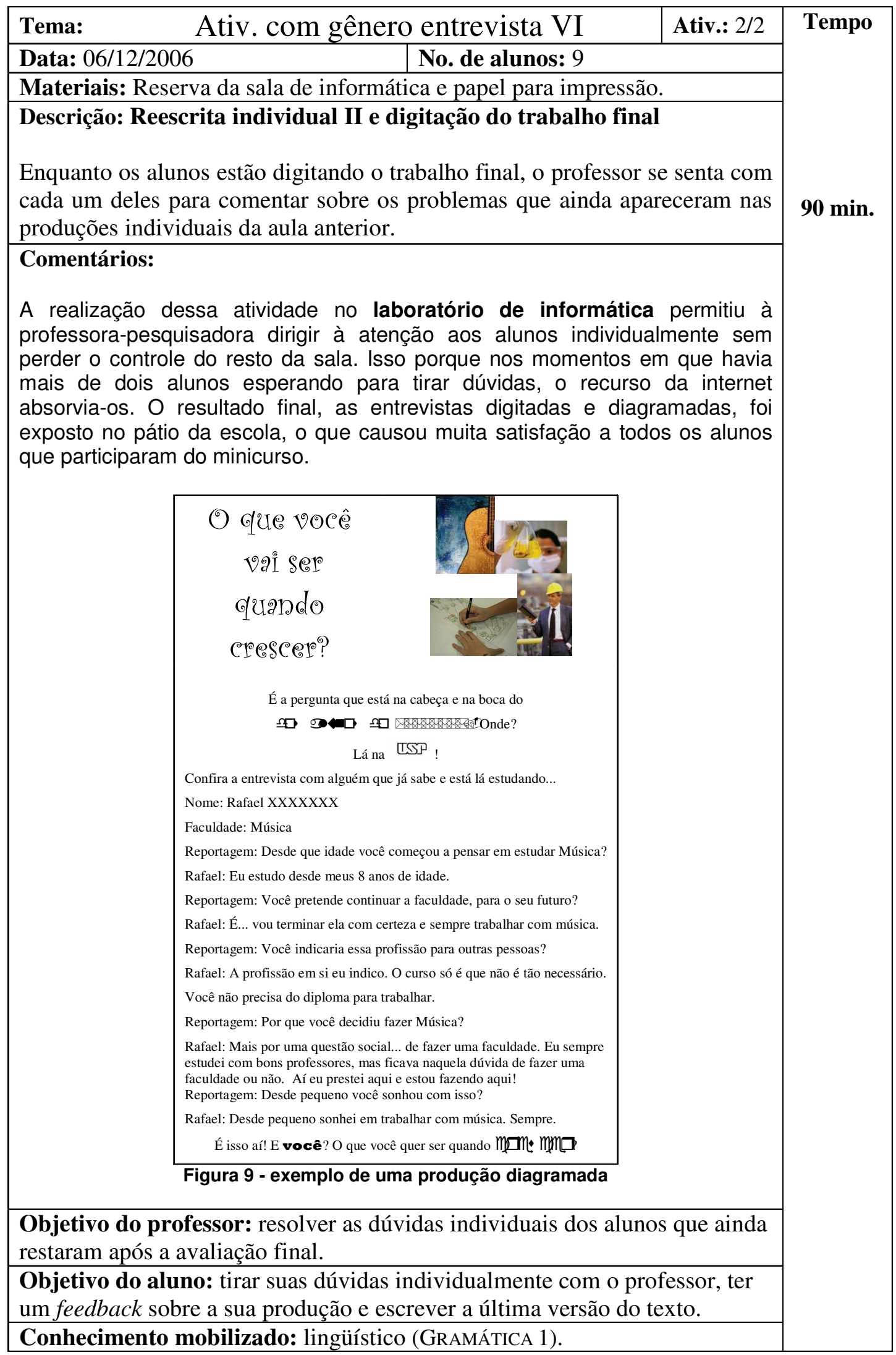




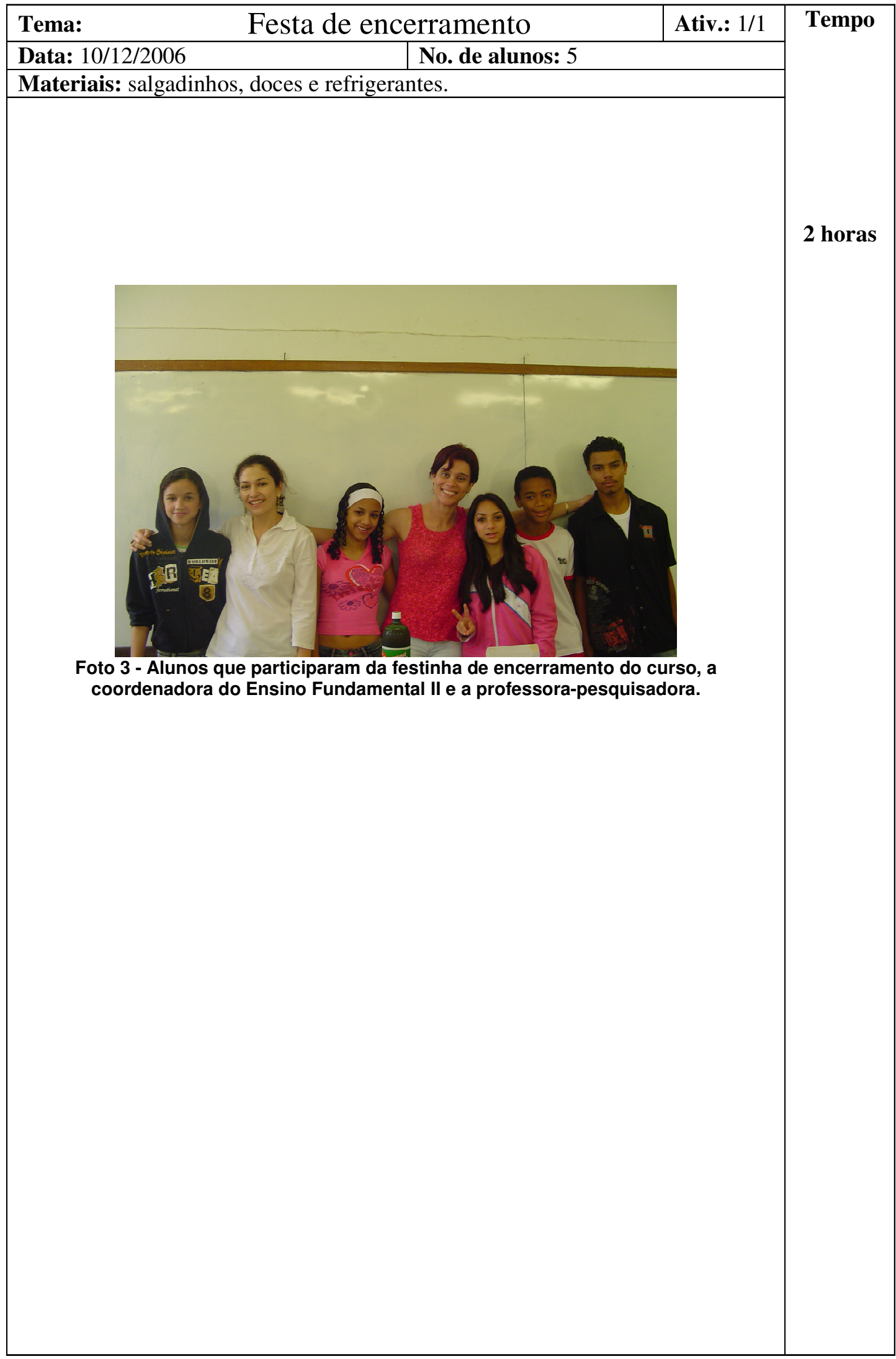




\subsection{Os resultados}

Como a ADeF foi realizada com base em uma produção cujo gênero (carta informal) era diferente daquele trabalhado ao longo do minicurso de oralidade, leitura e escrita (entrevista, inserido no tipo de discurso jornalístico) pelos motivos anteriormente explicados (seção 6.2), os resultados referidos nesta seção foram baseados nas indicações de progresso entre a produção inicial (transcrição de uma entrevista) e a produção final (texto resultante de todo trabalho com o gênero textual entrevista, SEM A CORREÇÃO FINAL E O LAY-OUT QUE FOI CRIADO PARA O MURAL DA ESCOLA).

Os principais problemas que haviam sido detectados na $\mathrm{ADeF}$ (pontuação, acentuação e ortografia) apareceram novamente na produção inicial, mas em proporção ligeiramente diferente à observada na média feita entre todas as produções avaliadas naquela ocasião.

Se, na ADeF, em média, aproximadamente $10 \%$ de todas as palavras de cada texto apresentavam algum tipo de problema de grafia, na produção inicial esse índice caiu para 8\%. Ainda que seja difícil apontar para uma razão específica que tenha motivado esse avanço, algumas hipóteses foram aventadas pela professora-pesquisadora:

- maior envolvimento com a produção escrita por parte dos alunos que, naquele momento, já participavam do projeto há quase 1 mês;

- a freqüência da do ato da escrita;

- as atividades de leitura realizadas em sala de aula e em casa, por meio das revistas (que foram doadas aos alunos);

- o fato de se tratar de um texto transcrito e, portanto, não exigir dos alunos que elaborassem seus próprios pensamentos, mas os de outrem.

A relação entre os problemas de ortografia e acentuação e os demais apresentados nos textos, porém, continuou semelhante: próximo de $50 \%$, tanto na $\mathrm{ADeF}$ quanto na primeira produção, sendo que as principais ocorrências estiveram relacionadas à falta de letra maiúscula no 
início de frase e nos nomes das carreiras cursadas pelos entrevistados, além de falta de acentuação de proparoxítonas.

Observou-se, por outro lado, um avanço com relação aos problemas de pontuação: na ADeF, $48 \%$ de todos as inadequações estavam relacionadas à falta de vírgula e de ponto final em praticamente todas as sentenças; na produção inicial, esse valor foi de 33\%, relacionado ao uso equivocado da vírgula no lugar do ponto final ("Meu nome é Gilberto RXXX,"), da vírgula em lugar inapropriado dentro do período ("É, aquilo o que eu falei dinovo, eu acho que...”) ou à falta de ponto final (“Eu tenho 23 anos”).

Oito, das nove produções, não apresentaram problemas no uso do ponto de interrogação.

A "novidade" que apareceu na produção inicial, mas não na $\mathrm{ADeF}$, foi uma grande ocorrência de marcadores conversacionais, tais como "ah" (grafado como "há”), “né”, “aî", "então", além da repetição de termos e partes de sentenças, duas características próprias da fala oral.

A maior freqüência dessas marcas de oralidade esteve relacionada ao fato de se tratar de uma $\operatorname{transcrição~}^{107}$. Como o objetivo da escolha pelo trabalho com o gênero entrevista se deu justamente para que tais interferências no texto escrito pudessem ser discutidas em sala de aula, a sua ocorrência possibilitou uma boa chance para que o assunto fosse detalhado.

Outras ocorrências com menor freqüência estiveram relacionadas à relativa falta de coerência entre algumas perguntas e respostas (“A: O que você esta fazendo aqui? B: Eu pretendo arquitetura urbanismo") e problemas na concordância verbal.

Assim, a relação quantitativa entre os problemas mais freqüentes e as unidades lingüísticas ${ }^{108}$ na produção inicial pode ser resumida pelo gráfico da figura 10.

\footnotetext{
${ }^{107}$ Ainda que não se tenha optado por uma transcrição que respeitasse o padrão acadêmico, uma vez que esses textos foram transcritos pelos próprios alunos, para atividades posteriores em sala de aula. Por isso, a necessidade de uma transcrição muito simplificada e acessível.

${ }^{108}$ Forma como Schneuwly, Dolz e Noverraz (2007) se referem à pontuação, acentuação, ortografia, sintaxe, entre outras categorias gramaticais.
} 


\section{RELAÇÃO ENTRE PROBLEMAS MAIS FREQÜENTES E UNIDADES LINGÜÍSTICAS NA PRODUÇÃO INICIAL}

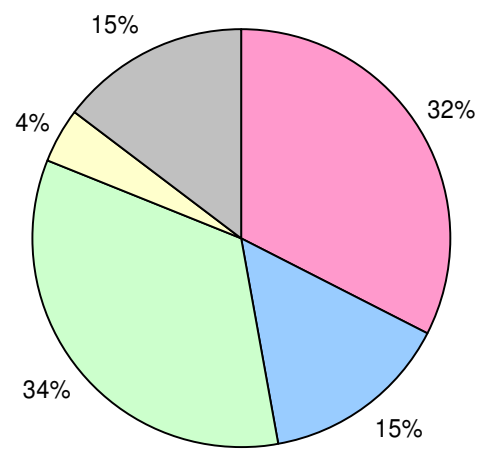

$\square$ Pontuação

$\square$ Acentuação

$\square$ Ortografia

$\square$ Outros

$\square$ Marcas de oralidade

Figura 10 - Relação entre os problemas mais freqüentes e as unidades lingüísticas na produção inicial

Ainda que a tendência geral entre as proporções tenha se mantido na produção final, algumas alterações significativas chamam à atenção:

\section{RELAÇÃO ENTRE PROBLEMAS MAIS FREQÜENTES E UNIDADES LINGÜÍSTICAS NA PRODUÇÃO FINAL}

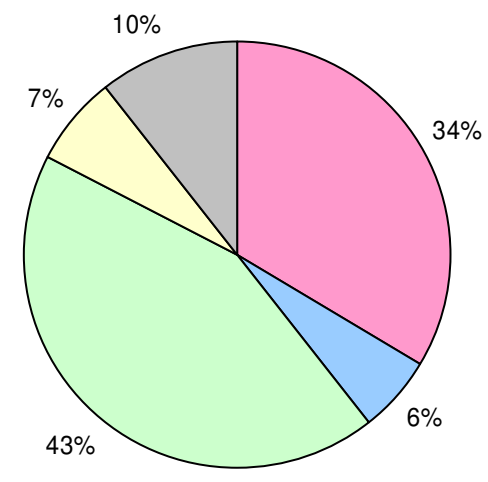

$\square$ Pontuação

$\square$ Acentuação

$\square$ Ortografia

$\square$ Outros

$\square$ Marcas de oralidade

Figura 11 - Relação entre os problemas mais freqüentes e as unidades lingüísticas na produção final

Enquanto os problemas relacionados à acentuação foram $9 \%$ menos freqüentes (proporcionalmente aos demais) na produção final do que na inicial, os de ortografia representaram $9 \%$ a mais. Apoiando-se em duas observações de sala de aula, aventa-se a 
hipótese de que a atividade epilingüística relacionada aos problemas com a acentuação ${ }^{109}$ tenha sido mais bem compreendida pelos alunos, por ser simples e objetiva, e conter de forma explícita a correção das palavras, enquanto as atividades com ortografia, embora simples, foram realizadas em quantidade aquém da necessidade daqueles alunos. Ainda assim, se comparados numericamente os resultados entre a produção final e a inicial, é possível de se afirmar que mesmo nos problemas com relação à ortografia houve uma melhora expressiva entre ambas as produções:

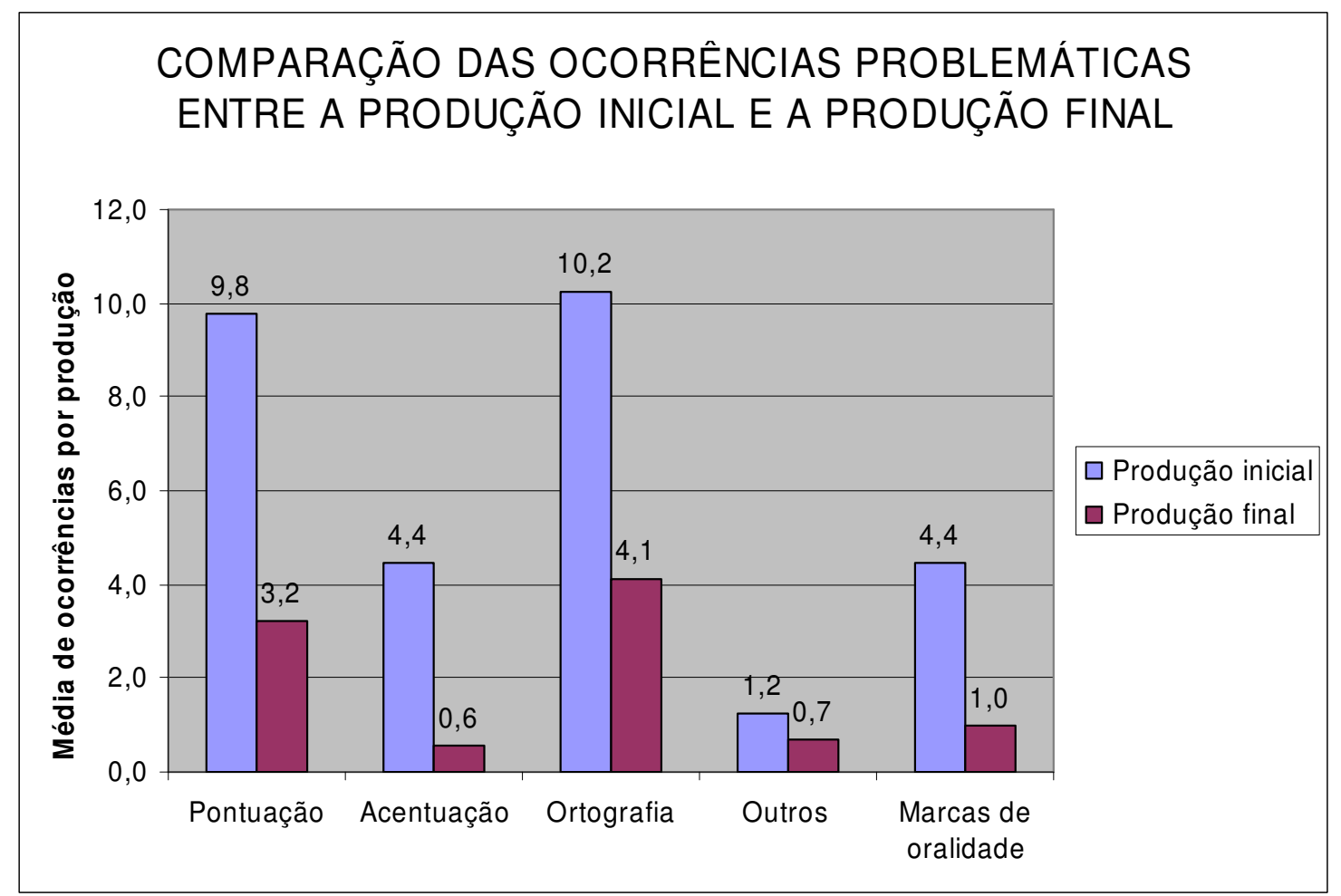

Figura 12 - Comparação das ocorrências problemáticas entre a produção inicial e a produção final

Os principais problemas de pontuação que permaneceram na produção final estavam relacionados ao uso da vírgula dentro do período ("Apoiou bastante meu pai apesar de ser uma coisa assim que as pessoas...”; “eu entrei direto no terceiro ano, eu não fiz cursinho, eu morava em natal"). Porém, observou-se que os alunos que demonstraram maior entrosamento com a escrita conseguiram melhorar seu desempenho em todos os aspectos da elaboração do texto, mas aqueles que apresentavam maiores dificuldades em elaborarem um texto escrito conseguiram apenas sanar aqueles problemas específicos, tratados em sala de aula como exemplos. Por esse motivo, esses últimos resolveram, em parte, os problemas de acentuação e ortografia, mas foram incapazes de solucionar aquelas incorreções que necessitavam de um

\footnotetext{
${ }^{109}$ Odd man out, página 198.
} 
nível superior de elaboração escrita, como é o caso da pontuação ${ }^{110}$. Se comparados os resultados das produções com maior incidência de problemas com aquelas que atingiram resultados mais positivos, essa constatação fica clara:

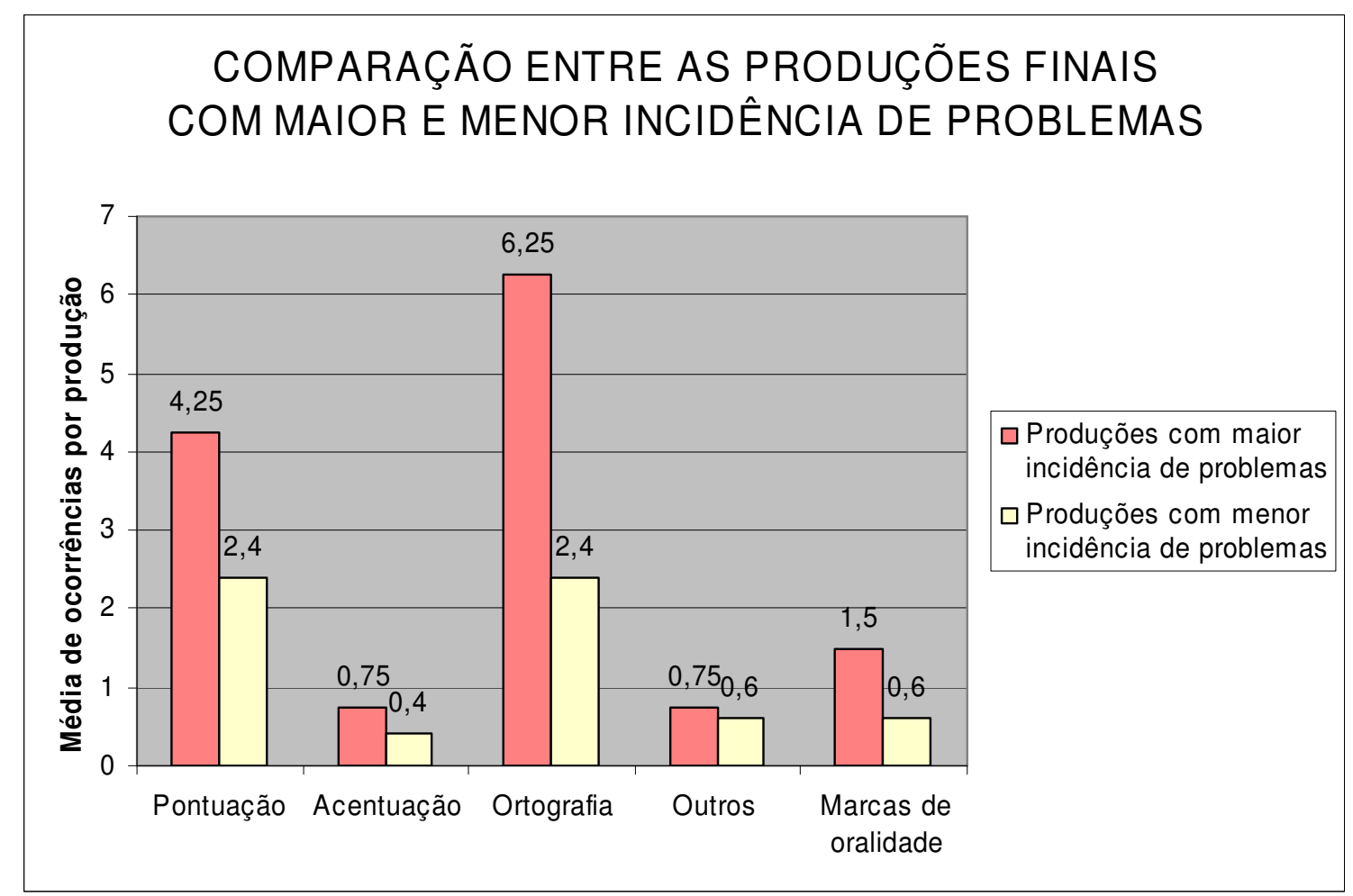

Figura 13 - Comparação das ocorrências problemáticas nas produções finais com maior e menor incidência de problemas

Um dado significativo compartilhado por todas as produções foi o de que aqueles problemas classificados como "outros", em sua maioria, relacionados à falta de coerência local (perguntas com respostas mal não adequadas), apresentaram pequena variação entre as ocorrências na produção inicial e final, revelando a necessidade de terem sido objeto de mais atenção por parte da professora-pesquisadora. Similarmente ocorreu com a interferência da oralidade na escrita por meio da repetição de termos ou frases, ainda que a repetição de pronomes tenha sido, em parte e em alguma produções, eliminada. Longe de representarem ameaça a proposta aqui apresentada, essas constatações reforçam a necessidade deste trabalho - mais prolongado, entretanto.

\footnotetext{
${ }^{110}$ Afirmação com base em constatações de Schneuwly, Dolz e Noverraz (2007, p. 115).
} 
A comparação qualitativa das produções iniciais e finais também sugere progressos ${ }^{111}$. A presença de tipologia textual própria do gênero entrevista - tais como a localização do entrevistado e do entrevistador, além da presença de um público-alvo - em $33 \%$ das produções demonstra um domínio progressivo do gênero:

\begin{tabular}{|l|l|}
\hline \multicolumn{1}{|c|}{ Produção Inicial Aluno 4 } & \multicolumn{1}{|c|}{ Produção final Aluno 4 } \\
Qual é o seu nome? & \\
R: Milena & A Escola XXXXXXXX foi na USP e entrevistou \\
Qual sua idade? & vários alunos pra saber como foi que eles entraram \\
R: 21 anos & lá! Confira agora uma entrevista com uma futura- \\
Qual curso você faz? & dentista! \\
R: Odontologia & Qual é o seu nome? \\
O que levou você fazer o curso? & R: Milena. \\
R: Há, eu tinha primos que já fizeram odonto & Qual sua idade? \\
aí, eu visitei a clinica e gostei da profissão. & R: 21 anos. \\
Seus pais aceitaram? & Qual curso você faz? \\
R: aceitaram. & R: Odontologia. \\
Foi difícil? & O que levou você fazer o curso? \\
R: Foi, porque eu vim de escola publica, aí pra & R: Eu tinha primos que já fizeram Odontologia. Eu \\
estudar aqui é difícil, tive que fazer cursinhos, & visitei a clínica e gostei da profissão! \\
ai consegui passar. & Seus pais aceitaram? \\
(comentou: é eu acho que a maioria do pessoal & R: Aceitaram. \\
é de escola pública né? & Foi difícil? \\
R: É não, nem sempre né, a maioria é de escola & R: Foi, porque eu vim de escola pública, para \\
particular & entrar aqui é difícil, eu tive que fazer cursinhos, até \\
Há, eu acho que só obrigada. & consegui passar! Acho que a maioria do pessoal é \\
R: Há, de nada. & de escola pública, né? \\
& R: Nem sempre, a maioria é de escola particular! \\
& Eu acho que só, obrigada! \\
& R: De nada! \\
\hline
\end{tabular}

Quadro 8 - Produção inicial e produção final do aluno 4.

Tendo em vista as considerações apresentadas relativas ao minicurso de oralidade, leitura e escrita, ministrado a 9 alunos de uma escola da prefeitura de São Paulo, todos participantes VOLUNTÁRIOS das 22 horas de aula, considerou-se que o uso de atividades lúdicas como recurso para o ensino e a aprendizagem em aulas de Língua Portuguesa no Fundamental II foi positivo e conseguiu alcançar os objetivos traçados no início deste projeto.

Assim, ao mesmo tempo em que se revelou muito eficiente no sentido de melhorar vários aspectos na esfera relacional da sala de aula - tais como maior motivação por parte dos alunos

${ }^{111}$ Todos os textos, digitados, encontram-se no Anexo H e I. 
e do professor, mais interação durante as atividades, melhor qualidade na participação de todos - o uso de atividades lúdicas também propiciou o aprimoramento da leitura e da escrita, objetivo central desta proposta metodológica. Objetivos esses sintetizados na cartinha entregue no último dia de aula pelo aluno mais novo e mais tímido do grupo, escrita com palavras simples, mas poderosas:

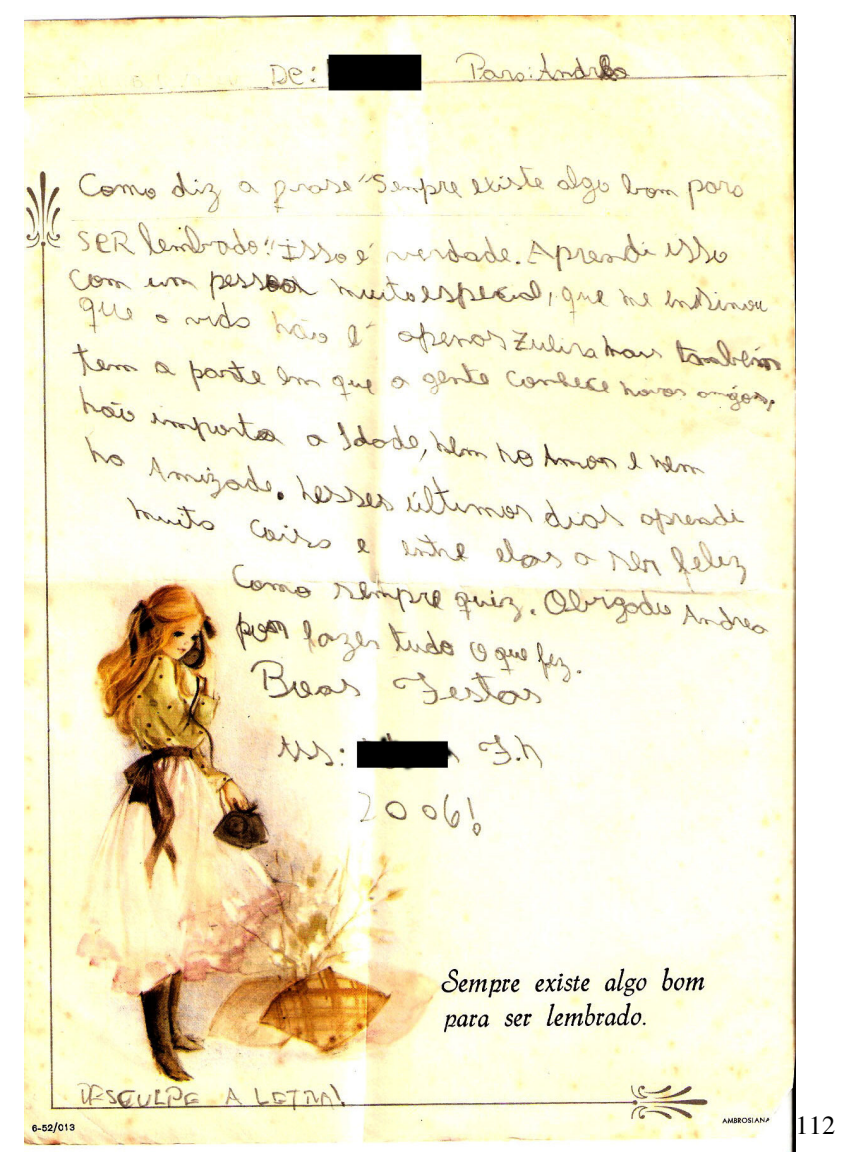

Figura 14 - Carta de um dos alunos participantes do minicurso de oralidade, leitura e escrita à professorapesquisadora

\footnotetext{
112“Como diz a frase "Sempre existe algo de bom para ser lembrado". Isso é verdade. Aprendi isso com um pessoa muito especial, que me ensinou que a vida não é apenas zueira mais também tem a parte em que a gente conhece novos amigos, não importa a Idade nem no Amor nem na Amizade. Nesses últimos dias aprendi muita coisa e entre elas a ser feliz como sempre quis. Obrigado Andréa por fazer tudo o que fez. Boas festas Ass: E.... F. N. 2006!"
} 


\title{
CONSIDERAÇÕES FINAIS
}

\author{
A língua só tem existência no jogo que se joga na sociedade, na interlocução. E é no interior \\ de seu funcionamento que se pode procurar estabelecer as regras de tal jogo. \\ João Wanderley Geraldi (1985, p. 43)
}

O problema que motivou esta pesquisa relaciona-se ao baixo grau de letramento verificado entre os alunos das séries finais do Ensino Fundamental II, apontado tanto por inúmeras pesquisas acadêmicas (BEZERRA, 2004; SEMEGHINI-SIQUEIRA, 2006b), quanto atestado por exames nacionais, como o Prova Brasil (2005) e o SAEB (2003), estaduais, como o SARESP (2004), e internacionais, como o PISA (2000, 2003). Ainda que se compreenda que a responsabilidade de se oferecer um ensino de qualidade, capaz de desenvolver não apenas as habilidades de leitura e escrita, mas da cidadania plena, direito constitucionalmente garantido $^{113}$, não dependa exclusivamente da escola, certamente entende-se também que essa instituição desempenha um papel central nessa questão.

Nesse contexto, cabe à disciplina Língua Portuguesa:

[...] organizar um conjunto de atividades que possibilitem ao aluno desenvolver o domínio da expressão oral e escrita em situações de uso público da linguagem, levando em conta a situação de produção social e material do texto [...] e selecionar, a partir disso, os gêneros adequados para a produção do texto, operando sobre as dimensões pragmática, semântica e gramatical. (BRASIL, PCN LÍNGUA PORTUGUESA - TERCEIRO E QUARTO CICLOS, 1998, p. 49).

Portanto, é prioridade dessa disciplina o ensino e a aprendizagem da leitura e da escrita competentemente. Porém, identificada por Neves (2003) e Semeghini-Siqueira (1998, 2006a) como a principal atividade realizada em aulas de Língua Portuguesa, o trabalho com gramática (entendida apenas como metalinguagem) foi também apontado por Semeghini-

\footnotetext{
113 Pelo artigo 205 da Constituição de 1988, onde se lê: “A educação, direito de todos e dever do Estado e da família, será promovida e incentivada com a colaboração da sociedade, visando ao pleno desenvolvimento da pessoa, seu preparo para o exercício da cidadania e sua qualificação para o trabalho." (BRASIL CONSTITUIÇÃO, 1988, p. 94).
} 
Siqueira (1977, 1997, 2001, 2005, 2006b, 2006c), Franchi (1991), Geraldi (1985, 1991, 2002), Travaglia (1996) e Possenti (1996) como sendo ineficiente enquanto recurso capaz de desenvolver adequadamente tais habilidades. Esses mesmos teóricos defendem a primazia do uso do tempo de aula em atividades lingüísticas e epilingüísticas para essa finalidade.

Diante dessa problemática, a necessidade de estratégias mais eficazes, que contemplem a realização de atividades lingüísticas e epilingüísticas em Língua Portuguesa e possibilitem melhores resultados de aprendizagem, é urgente. As atividades lúdicas, por "1. valorizarem o prazer funcional; 2. serem desafiadoras; 3. criarem possibilidades ou disporem delas; 4. possuírem dimensão simbólica; 5. expressarem-se de modo construtivo ou relacional" (MACEDO, 2006, p. 36) e tratarem-se de “[...] eficientes instrumentos de ensino e treinamento para alunos de todas as idades e em muitas situações, porque são altamente motivadores [os jogos] e porque comunicam muito eficazmente os conceitos e fatos de muitos assuntos" (ABT, 1974, p. 12) afigurou-se como a alternativa escolhida por este trabalho, pautando-se pela experiência bem sucedida com esse tipo de atividade desenvolvida no ensino de Língua Estrangeira, notadamente, de Língua Inglesa sob a influência dos preceitos da Abordagem Comunicativa praticados pela corrente metodológica conhecida como Task-base Language Teaching, no qual as atividades lúdicas desempenham função central no ensino e aprendizagem.

A aproximação de experiências deu-se com base em Jovanovic (1992, p. 178), que afirma “[...] que todos os códigos lingüísticos são instrumentos de comunicação e, como tais, devem se encarados de modo idêntico tanto por aqueles que ensinam, quanto por aqueles que aprendem (ou deveriam aprender)" [grifo do autor], sugerindo que o trabalho realizado com língua materna e língua estrangeira na escola poderia ser semelhante. Outra voz significativa que orientou a escolha por um modelo consagrado de uso de atividades lúdicas no contexto escolar foi a de Possenti (1996, p. 16) que considera “[...] uma decisão [...] importante, no domínio do ensino de língua materna, é que não se façam experiências. [...] É que, se o experimento fracassa, não se desperdiçam amostras de matérias, mas pedaços de vidas, partes de projetos dos alunos, às vezes, vidas e projetos inteiros."

A opção pela seqüenciação das atividades realizadas segundo as orientações de Schneuwly, Dolz e Noverraz (2007) em Sequiências Didáticas, partindo de uma AVALIAÇÃo DiAGNÓsTiCA E FormATIVA (SEMEGHINI-SIQUEIRA, 1997), ocorreu porque tal procedimento vai ao 
encontro das rotinas de trabalho necessárias para a realização do briefing e debriefing, preconizada pelo Task-based Language Teaching, e defendida por Crookall e Oxford (1990), Bullards (1990) e Brougère (1999) como fundamental à otimização do aproveitamento do jogo enquanto recurso pedagógico.

Proceder-se-á agora a retomada do trabalho realizado, com o intuito de apresentar algumas considerações finais possíveis. No primeiro capítulo, tratou-se da metodologia e dos sujeitos da pesquisa. A escolha pela abordagem etnográfica deveu-se ao fato de que, tanto na Primeira Entrada em Campo, quanto na segunda, a coleta das informações necessárias para a reflexão sobre o uso de atividades lúdicas, enquanto recurso educativo, foi realizada por meio da observação das relações estabelecidas entre os sujeitos nos locais de pesquisa. As considerações relativas à experiência encontram-se descritas na retomada dos capítulos 5 e 6 , concernentes às Entradas em Campo.

O segundo capítulo foi dedicado à revisão teórica sobre o lúdico. Partindo da conceituação de "jogo", "brincadeira", "brinquedo" e "lúdico", procurou-se enfocar a relação entre jogo e Educação, e, em especial, as formas de sua inserção na aula de Língua Inglesa.

Embora autores como Brougère $(1995,1999)$ entendam que não existe jogo em situação escolar, dado o fato de sua necessidade intrínseca de auto-regulação e de seu caráter de processo, sem expectativas quanto à finalidade, o jogo é utilizado como recurso educativo desde, pelo menos, o Renascimento (KISHIMOTO, 2001, p. 28). Apoiado em argumentos de natureza mais empírica do que teórica, o uso do jogo na Educação baseia-se na melhora substancial da motivação, tanto de alunos quanto do professor, assim como na oportunidade de agência do aluno (BROUGÉRE, 1999, p. 136). Três importantes teorias da aprendizagem (às de Piaget, Vygotsky e Bruner) também apontam para a possibilidade de aproveitamento do jogo em favor da Educação (KISHIMOTO, 2001, p. 32-35).

A relação entre jogo e ensino de Língua Estrangeira (especialmente, de Inglês oferecido por cursos de idiomas) é também detalhada nesse capítulo. Enquanto nos Método de Gramática e tradução e Método de Leitura - cujas práticas se assemelham a algumas defendidas pela tradição escolar para o ensino de Língua Portuguesa - não se utilizam desse recurso, em metodologias como a Audiolingual, a Abordagem Comunicativa, e, sobretudo, o Task-based Language Teaching, o jogo ocupa um lugar de destaque entre os procedimentos realizados em 
sala de aula. Precedido pelo briefing, que é uma introdução dos elementos necessários para a sua execução adequada, e sucedido pelo debriefing, momento de reflexão sobre diversos aspectos da atividade lúdica, o jogo está intrinsecamente relacionado às demais estratégias de ensino e aprendizagem de Língua Inglesa. Trata-se, portanto, de um exemplo de uso bem sucedido, modelo para o presente trabalho, no momento da Segunda Entrada em Campo, o minicurso de oralidade, leitura e escrita.

Para que a utilização do jogo em aulas de Inglês como Língua Estrangeira pudesse ser melhor compreendida, optou-se pelo detalhamento das principais metodologias adotadas no contexto brasileiro, presente no terceiro capítulo. Embora a metodologia enfocada seja o Task-based Language Teaching (TBLT), pela centralidade que o jogo exerce em seus procedimentos de sala de aula, um breve relato sobre o Método de Gramática e Tradução, o Método de Leitura e o Audiolingual contextualizam momentos distintos da história (e das práticas) do ensino de Língua Estrangeira. Pertencente ao escopo teórico da Abordagem Comunicativa, que privilegia a interação à formação de hábito pela repetição, no TBLT, o jogo, especialmente entendido como simulação, guarda grandes semelhanças à TAREFA, que constitui uma atividade cuja relação com a realidade só pode ser recuperada pela imaginação (ELLIS, 2003, p. 179). Os procedimentos de PRÉ-TAREFA e PÓS-TAREFA são muito semelhantes aos de briefing e debriefing, com a única diferença de que no PÓS-TAREFA pode-se reapresentar a TAREFA, caso alunos e professor julguem necessário.

No capítulo quarto, o ensino de Língua Portuguesa é analisado sob quatro perspectivas: a da tradição escolar, a das avaliações oficiais do Ensino Fundamental, a dos Parâmetros Curriculares Nacionais, e a dos estudos lingüísticos ligados à Educação. Procurou-se contrastar os entendimentos dessas perspectivas sobre quatro questões basilares no ensino de Língua Portuguesa: (1) Para que se estuda LP (Língua Portuguesa)? (2) O que se estuda em LP? (3) O que é gramática? (4) Qual o seu papel no ensino de LP?

Para a tradição escolar, estuda-se Língua Portuguesa na escola para ser mais bem sucedido na vida, visão contestada pelos estudos lingüísticos - e pela observação da realidade social. A gramática, normativa e compreendida apenas em sua dimensão metalinguiística, é o principal elemento integrante das aulas dessa disciplina (NEVES, 2003; SEMEGHINI-SIQUEIRA, 1998, 2006a). Seu papel, já percebido como ambíguo (SEMEGHINI-SIQUEIRA, 2006, p. 9), 
é o de "[...] ritual imprescindível à legitimação de seu papel [do professor].” (NEVES, 2003, p. 45).

A análise comparativa dos resultados dos exames de avaliação de desempenho dos estudantes do ensino Fundamental em nível estadual (SARESP), nacional (Prova Brasil e SAEB) e internacional (PISA) revela que a maioria dos alunos paulistas apresenta algum tipo de restrição quanto à leitura, sendo que a interpretação de texto é a capacidade menos desenvolvida. Isso representa um percentual aproximado de $30 \%$ de estudantes matriculados no ensino Funadamental II incapazes de compreender funcionalmente o que lêem e, assim, à margem do processo de modernização que as tecnologias da informação (todas dependentes da leitura, tanto de textos, quanto de imagens) oferecem àqueles que sabem utilizá-las. Essa exclusão sutil, pois não impede o aluno de freqüentar a escola, mas não o habilita a compreender o mundo em que vive, expõe os resultados de uma prática pedagógica ineficiente, baseada, em grande parte, nos pressupostos da tradição escolar analisados anteriormente.

Os PCN de Língua Portuguesa dos terceiro e quarto ciclos (1998, p. 32), ou seja, do Fundamental II, por outro lado, sugerem que, por meio do ensino e a aprendizagem dessa disciplina:

[...]o aluno amplie o domínio ativo do discurso nas diversas situações comunicativas, sobretudo nas instâncias públicas de uso da linguagem, de modo a possibilitar sua inserção efetiva no mundo da escrita, ampliando suas possibilidades de participação social no exercício da cidadania.

Para tanto, articulados por meio do trabalho com gêneros textuais, a fala/escuta, leitura/escrita e análise lingüística devem ser os três principais eixos de estudo em Língua Portuguesa. Segundo esse documento, a gramática é compreendida em três dimensões: a lingüística, a epilingüística e a metalingüística, sendo que sua recomendação é no sentido de se priorizar atividades que façam uso das duas primeiras, em detrimento da última. A principal crítica, porém, que recai sobre os PCN (1998) diz respeito ao pouco subsídio em termos práticos disponível ao professor para a sua implementação (MILLER, 1998).

Segundo os estudos lingüísticos voltados à Educação, oferecer oportunidades igualitárias de acesso aos bens materiais e culturais disponíveis na sociedade e desenvolver as habilidades de 
leitura, oralidade ${ }^{114}$ e escrita são os objetivos fundamentais do ensino e aprendizagem de Língua Portuguesa (GERALDI, 1985). O trabalho com gêneros textuais em Sequiências Didáticas (SCHNEUWLY, DOLZ; NOVERRAZ, 2007) com base nos resultados de uma Avaliação Diagnóstoca e Formativa (SEMEGHINI-SIQUEIRA, 1997) e a prioridade da variedade padrão (SOARES, 1983, 1999; POSSENTI, 1996; GERALDI, 1985) sobre as demais são recomendados. A gramática, compreendida sob uma perspectiva plural, cuja abrangência engloba as dimensões lingüísticas, epilingüísticas e metalingüísticas (EGLÊ FRANCHI, 1984; CARLOS FRANCHI, 1991; GERALDI, 1991, 2002; TRAVAGLIA, 1996; POSSENTI, 1996; SEMEGHINI-SIQUEIRA, 1977, 1997) deve ser trabalhada em sala de aula no sentido de desenvolverem a leitura, a oralidade e a escrita.

Se, por um lado, muitos desses pressupostos teóricos assemelham-se ao que postulam os PCN, por outro, diferem-nos a profundidade e o pioneirismo, além da não recomendação do trabalho com metalinguagem (EGLÊ FRANCHI, 1984; CARLOS FRANCHI, 1991; GERALDI, 1985, 1991, 2002; TRAVAGLIA, 1996; SEMEGHINI-SIQUEIRA 1997, 1998, 2001, 2005, 2006a, 2006b, 2006c; POSSENTI, 1996; PERINI, 2005) enquanto recurso que promova o desenvolvimento das habilidades que nessa disciplina se propõe.

Nos capítulos 5 e 6 são apresentados os resultados dos dois momentos de pesquisa de campo realizadas para este trabalho. De cunho etnográfico-investigativo (GEERTZ, 1995; ERICKSON, 1989), a Primeira Entrada em Campo, relatada no capítulo 5, foi realizada em uma escola particular de São Paulo, onde foram observadas aulas de Língua Portuguesa e de Língua Inglesa extracurricular, sendo que esta última, oferecida por um curso de idiomas que deslocava seus professores para ministrar aulas na escola em questão. Foram sujeitos desse momento da pesquisa as professoras de Língua Portuguesa e Língua Inglesa, Marta e Ingrid $^{115}$, respectivamente, e 11 alunos em comum a ambas as classes.

Se, nas aulas de Língua Inglesa extracurricular, a variedade, tanto de atividades quanto de momentos distintos proporcionados pela metodologia (uma adaptação da Abordagem Comunicativa promovida pelo próprio instituto de idiomas) pareceu ser a principal influência positiva no ensino e aprendizagem daquele idioma, dada a participação efetiva dos alunos e os

\footnotetext{
${ }^{114}$ (FÁVARO, ANDRADE; AQUINO, 2000)

${ }^{115}$ Nomes fictícios criados para preservar a identidade de ambas as professoras.
} 
resultados compatíveis com o nível de proficiência esperado naquele estágio, na sala de Português, o excesso de atividades metalingüísticas e de tempo "morto", assim como a falta de conexão entre as atividades realizadas confirmaram não apenas os resultados dos estudos de Semeghini-Siqueria (1998, 2006a) e Neves (2003), mas também, os efeitos negativos dessas práticas expostos pela análise dos dados relativos aos exames de avaliação de desempenho dos estudantes do Fundamental II.

As atividades lúdicas realizadas em Língua Inglesa extracurricular representaram $60 \%$ do tempo observado, compreendendo no principal recurso de ensino e aprendizagem empregado. Notou-se que os procedimentos de briefing e debriefing auxiliaram na organização da aprendizagem, resultando não apenas na economia de tempo (proporcionada pelas intruções claras e objetivas, que compreendem o briefing), como também, no aprofundamento das questões trabalhadas durante os jogos (debriefing).

Na aula de Língua Portuguesa, a rigor, não ocorreu jogo algum, porque a única atividade que poderia ser considerada como lúdica - uma cruzadinha de verbos - foi realizada com propósito de avaliação - inviabilizando qualquer um dos elementos necessários para a ocorrência de uma situação lúdica.

Constatou-se, por meio da Primeira Entrada em Campo, uma realidade muito semelhante à descrita por Neves (2003) e Semeghini-Siqueria (1998, 2006a), quanto à aula de Língua Portuguesa. Já, na aula de Língua Inglesa extracurricular, observou-se que as atividades lúdicas podem ser recursos interessantes para promoverem o ensino e a aprendizagem integrados à realidade do aluno. Instruções claras que as antecedam assim como a reflexão posterior acerca de sua relação com a aprendizagem são elementos que propiciam maior sucesso em sua realização.

No capitulo 6, descreve-se a experiência da realização de um minicurso de oralidade, leitura e escrita, cuja duração foi de 22 horas. Participaram 9 alunos, provenientes da $6^{\mathrm{a}}$, $7^{\mathrm{a}}$ e $8^{\mathrm{a}}$ série do Ensino Fundamental de uma escola pública da prefeitura de São Paulo. Essa Segunda Entrada em Campo seguiu os princípios da etnográfica conhecidos por Investigação/ação (GÓMEZ; FLORES; JIMÉNEZ, 1990), pelos quais o pesquisador participa da comunidade onde realiza suas observações/intervenções. 
Partindo de uma Avaliação Diagnóstica e Formativa (SEMEGHINI-SIQUEIRA, percebeu-se a necessidade dos alunos participantes do minicurso sobre a diferença entre a língua falada e a escrita. Para tanto, organizou-se uma Seqüência Didática (SCHNEUWLY; DOLZ; NOVERRAZ, 2007) cujo gênero textual trabalhado foi a entrevista. Optou-se pela realização de uma introdução ao tipo textual (MAINGUENEAU, 2002) jornalístico, por compreender-se que os alunos, dadas as restrições impostas por sua condição social bastante precária, dispunham de pouco acesso a tais textos.

Todas as atividades realizadas em sala de aula pautaram-se pelo exercício de conhecimentos lingüísticos $(78,7 \%)$ e epilingüisticos $(22,3 \%)$, sendo que os procedimentos para a sua realização tornaram-nas em atividades lúdicas, iniciadas por procedimentos de briefing e finalizadas pelos de debriefing, como preconiza o TBLT (nesse escopo teórico, chamados de PRÉ e PÓS-TAREFA).

Ainda que não seja possível afirmar com certeza se a melhora na escrita, na oralidade e na leitura dos alunos que participaram deste projeto ocorreu em decorrência das atividades lúdicas nele realizadas, quer seja pelo pouco tempo de contato, quer seja porque tal avaliação só tem sentido dentro de um processo contínuo, como aponta Possenti (1996, p. 87):

[...] para esse tipo de erros, ortográficos ou gramaticais em sentido mais amplo (concordância, regência, etc.), é ingênuo supor que há correção imediata possível. Ainda mais ingênuo é supor que se eliminam por exercícios. Formas inadequadas desse tipo tenderão a desaparecer com o domínio progressivo da variedade padrão [...].

É possível, porém, notar que a qualidade da participação em sala de aula foi muito diferente daquela relatada pelos mesmos alunos sobre suas aulas regulares de Língua Portuguesa. Nesse sentido, segundo Macedo, Petty e Passos (2000, p. 14):

[...] sabe-se que certas atitudes (Coll, 1987), como ser atento, organizado e coordenar diferentes pontos de vista são fundamentais para obter um bom desempenho ao jogar e também podem favorecer a aprendizagem na medida em que a criança passa a ser mais participativa, cooperativa e melhor observada. Além disso, a ação de jogar exige, por exemplo, realizar interpretações, classificar e operar informações, aspectos que têm uma relação direta com as demandas relativas às situações escolares. (grifo nosso). 
Portanto, pode-se dizer que a utilização da capacidade lógica e dedutiva em um ambiente de aprendizado contextualizado proporcionou a utilização de diversas habilidades que não apenas as cognitivas, resultando em uma aprendizagem mais efetiva.

Outro ganho importante observado foi em relação à disciplina. Com a utilização plena de todos os momentos da aula, não houve tempo para ociosidade. Além disso, a dinâmica criada, por arranjos variados de interação entre os alunos, trouxe uma melhora considerável na esfera relacional, tanto entre os próprios alunos, quanto entre eles e o professor.

Nesse sentido, a abertura para a criatividade, a agência e a expressão individual foi um fator decisivo para evitar a indisciplina. Como ressalta Arendt (1991, p. 35), “[...] somente a pura violência é muda, e por este motivo a violência, por si só, jamais pode ser grandeza." Portanto, a violência é a antítese da palavra; quando não há mais o que se dizer - ou não há espaço para dizê-lo - é o momento em que ela ocorre. No caso, como todos tinham acesso e oportunidade à palavra, não ocorreu nenhum problema dessa natureza em sala de aula.

Faz-se necessário, porém, que algumas questões de ordem prática sejam mencionadas. A preparação dos materiais para a utilização em sala de aula, assim como a própria preparação da aula demandaram bastante tempo, trabalho e materiais nem sempre disponíveis na escola. Ainda que as atividades lúdicas possam ser re-utilizadas, é notório que um professor que trabalhe com carga horária expandida para conseguir sustentar sua família não teria tempo nem condições financeiras para a elaboração de tais artefatos.

Desta forma, mesmo que esta proposta de trabalho possa representar uma contribuição muito pequena diante da dimensão do problema relativo ao letramento, ainda assim, sua validade está, senão pelas suas proposições, mas pela reiteração da necessidade de uma discussão séria sobre a necessidade de novas propostas de ensino de Língua Portuguesa; para que não se caia na falácia de se dizer que tal problema é congênito, sem solução e, portanto, nada temos a fazer. Nas palavras de Freire (1982, p. 40):

É importante perceber que a realidade social é transformável; que feita pelos homens, pelos homens pode ser mudada; que não é algo intocável, um fado, uma sina, diante de que só houvesse um caminho: a acomodação a ela. 


\section{REFERÊNCIAS BIBLIOGRÁFICAS}

ABT, C. C. Jogos simulados: estratégia e tomada de decisão. Rio de Janeiro: J. Olympio, 1974.

ALMEIDA FILHO, J. C. P. Dimensões Comunicativas no Ensino de Línguas. Campinas: Pontes, 1993.

ARANTES, V.A. (org.). Jogo e projeto. São Paulo: Summus editorial, 2006.

ARENDT, H. A condição humana. Rio de Janeiro: Forense, 1991, p. 15 - 30.

APPLE, M.W. Política cultural e educação. São Paulo: Cortez, 1999.

AZEVEDO, R. Restaurar é preciso; reformar não é preciso. In: Revista Veja. São Paulo: Ed. Abril, 12/09/2007, p. 98, 99.

Loyola, 1999.

Preconceito lingüístico: o que é, como se faz. 44a . ed., São Paulo: Edições

BECHARA, E. Ensino da gramática. Opressão? Liberdade? $3^{\text {a }}$. ed., São Paulo: Ática (Série Princípios), 1987.

BERGO E GOMES, N. S. A língua estrangeira e sua inclusão no currículo da educação do povo: necessária ou supérflua? 1985. 321 f. Dissertação (Mestrado em Educação) - FGV Rio, Fundação Getúlio Vargas, Rio de Janeiro, 1985.

BEZERRA, G.G.R. Contribuição às reflexões sobre práticas de ensino de gramática e formação de professores de $\mathbf{1}^{\mathrm{a}}$. a 4a . séries: atividades epilingüísticas em foco. $2004.210 \mathrm{f}$. Dissertação (Mestrado em Educação) - Faculdade de Educação, USP, São Paulo, 2004.

BOURDIEU, P. Os usos sociais da ciência: por uma sociologia clínica do campo científico. São Paulo: UNESP, 2002.

BRASIL, Constituição (1988). Constituição da República Federativa do Brasil. Brasília, DF: Senado, 1988.

BRASIL. Secretaria de Educação Fundamental. Parâmetros curriculares nacionais: terceiro e quarto ciclos do ensino fundamental: língua portuguesa/Secretaria de Educação Fundamental. Brasília: MEC/SEF, 1998.106 p. 
BRASIL. Secretaria de Educação Fundamental. Parâmetros curriculares nacionais: terceiro e quarto ciclos do ensino fundamental: introdução aos parâmetros curriculares nacionais / Secretaria de Educação Fundamental. - Brasília: MEC/SEF, 1998.174 p.

BRASIL. Secretaria de Educação Fundamental. Parâmetros curriculares nacionais: terceiro e quarto ciclos do ensino fundamental: língua estrangeira/ Secretaria de Educação Fundamental. Brasília: MEC/SEF, 1998.120 p.

BROUGÈRE, G. Jogo e Educação. Porto Alegre: Artmed. 1995.

BULLARD, N. Briefing and debriefing. In: CROOKALL, D.; OXFORD, R. L. (org) Simulation, Gaming, and Language Learning. Nova York: Newbury House Publishers, 1990. p. 55-66.

BRUNER, J. S. O processo da educação. São Paulo: Companhia Editora Nacional, 1973.

CARRIEL, A. L. M. L. Embuste? Ficção? Utopia? O ensino de Língua Inglesa na escola pública: mistérios que complicam, caminhos que viabilizam. 2002. 251 f. Dissertação (Mestrado em Educação), FEUSP, USP, São Paulo, 2002.

CIPRO NETO, P., INFANTE, U. Gramática da Língua Portuguesa. São Paulo: Scipione, 1998 , p. $8-11$.

CROOKALL, D.; OXFORD, R. L. Linking Language learning and simulation gaming. In: Simulation, Gaming, and Language Learning. Nova York: Newbury House Publishers, 1990.

CUNHA, A.G. da. Dicionário Etimológico da Língua Portuguesa. Rio de Janeiro: Nova Fronteira, 1982.

DELIBO, J. A. A Formação e prática do professor de inglês: repensando o espaço da língua materna. 1999.202 f. Tese (Doutorado em Educação), FEUSP, USP, São Paulo, 1999.

DUBOIS, J. et alii. Dicionário de Lingüística. São Paulo: Cultrix, 1973, p. 378.

ELLIS, R. Task-based language learning and teaching. Oxford: Oxford University Press, 2003.

ERICKSON, F. Métodos Cualitativos de investigación sobre la enseñanza. In: WITTROCK, M.C. (org) La investigación de la enseñanza, II. Métodos cualitativos y de observación. Barcelona: Ediciones Paidos, 1989. p. 195 - 301. 
FÁVERO, L. L.; ANDRADE, M. L. C. V. O.; AQUINO, Z.G.O. Oralidade e escrita: perspectivas para o ensino de língua materna. São Paulo: Cortez, 2000.

FERRO, G. D. M. A formação do professor de inglês: Trajetória da prática de ensino de Inglês na Universidade de São Paulo. Tese (Doutorado em Educação). 1998. 179 f. FEUSP, USP, São Paulo,1998.

FRANCESCHINI, F. Notícias e reportagens: diferenças sutis. Rio de Janeiro: Comum, v.9 no 22 - p. 144 a 155 - jan/jun 2004

FRANCHI, C. Criatividade e gramática. São Paulo: SEE/CENP, 1991.

FRANCHI, E. E as crianças eram difíceis... A redação na escola. São Paulo: Martins Fontes, 1984.

FREIRE, P. Ação cultural para a liberdade. 8ª ed. Rio de Janeiro: Paz e Terra, 1982.

GEERTZ, C. Uma descrição densa: por uma Teoria Interpretativa da Cultura. In: A interpretação das culturas. São Paulo: Guanabara Koogan, 1995. p. 14 - 41.

GERALDI, J. W. Portos de passagem. São Paulo: Martins Fontes, 1991.

(org). O texto na sala de aula - Leitura \& Produção. Cascavel: Assoeste,

1985.

Linguagem e ensino. Exercícios de militância e divulgação. $5^{\text {a }}$. Ed. Campinas: Mercado de letras, 2002.

GOMÉZ, G.R.; FLORES, J. G.; e JIMENEZ, E. G. Metodología de la investigación cualitativa. Barcelona: Ediciones Aljibe, 1999.

HORNER, D.; McGINLEY, K. Running simulation/games: a step-by-step guide. In: CROOKALL, D.; OXFORD, R. L. (org) Simulation, Gaming, and Language Learning. Nova York: Newbury House Publishers, 1990. p. 33-46.

HUIZINGA, J. Homo Ludens. São Paulo: Perspectiva, 2004.

JOVANOVIC, A. - Língua materna vs língua estrangeira : uma relação fundamental (porem menosprezada) no ensino / aprendizagem de línguas In: Revista da Faculdade de Educação São Paulo, v.18, n.2 , p.174-84, São Paulo, jul./dez. 1992. 
KISHIMOTO Tizuko Morchida. O jogo, a criança e a Educação. Tese (Livre Docência em Educação), 1992, 221 f. FEUSP, USP, São Paulo, 1992.

O jogo e a Educação infantil. São Paulo: Pioneira, 1994.

(org). O brincar e suas teorias. São Paulo: Pioneira, 1998.

(org). Jogo, brinquedo, brincadeira e a Educação. $5^{\text {a }}$. Ed.

São Paulo: Cortez, 2001.

Brincadeiras e narrativas infantis: contribuições de J. Bruner

para a pedagogia da infância. In: Pedagogia(s) da infância. Dialogando com o passado, construindo o futuro. Porto Alegre: Artmed, 2007. p. 249 - 275.

LANGRAN, J. e PURCELL, S. Language games and activities. Londres: CILT, 1994.

LARSEN-FREEMAN, D. Techniques and principles in language teaching. Hong Kong: Oxford University Press, 1986.

LEFFA, Vilson J. O ensino de línguas estrangeiras no contexto nacional. Contexturas, APLIESP, n. 4, p. 13-24, 1999.

LEONTIEV, A. Os princípios psicológicos da brincadeira infantil. In: Linguagem, desenvolvimento e aprendizagem. São Paulo: Ícone, 1999, p. 119 - 142.

LITTLEWOOD, W. Communicative Language Teaching. An introduction. 20a. ed. Cambridge: Cambridge Press, 1990.

LOPES, M. da G. Jogo na Educação: criar, fazer, jogar. 2a . ed. São Paulo: Cortez, 1999.

LUCKESI, C. C. Avaliação da aprendizagem escolar. São Paulo: Cortez, 2002.

MACEDO, L. DE, PETTY, A.L.S., PASSOS, N. C. Aprender com jogos e situações problema, Porto Alegre: Artmed, 2000, p.13-44.

Porto Alegre: Artmed, 2005.

Os jogos e o lúdico na aprendizagem escolar.

MACEDO, L. Jogo e projeto: irredutíveis, complementares e indissociáveis. In: ARANTES, V.A.. (org.). Jogo e projeto. São Paulo: Summus editorial, 2006. p. 15 - 45. 
MACHADO, N.J.; A vida, o jogo, o projeto. In: ARANTES, V.A.. (org.). Jogo e projeto. São Paulo: Summus editorial, 2006. p. 49 - 86.

MAINGUENEAU, D. Análise de textos de comunicação. São Paulo: Cortez Editora, 2002.

MARCUSCHI, L. A. Da fala para a escrita: atividades de recontextualização. São Paulo: Cortez Editora, 2004, p. 15 - 43.

MARTÍN-BARBERO, J. América Latina e os anos recentes: o estudo da recepção em comunicação social. In: SOUSA, M.W. Sujeito, o lado oculto do receptor. São Paulo: Brasiliense, 1995, p. 39-68.

MILLER, S. O epilingüístico: uma ponte entre o lingüístico e o metalingüístico trabalho com narrativas. Tese (Doutorado em Educação) 1998. 201 f. UNESP, Marília, 1998.

MOYLES, J. R. Só brincar? O papel do brincar na Educação infantil. Porto Alegre: Artmed. 2002.

NEVES, M. H. de M. Gramática na escola. $7^{a}$ ed., São Paulo: Contexto, 2003.

NUNAN, D. Designing tasks for the communicative classroom. Cambridge: Cambridge Language Teaching Library, 1993.

(org). Practical English Language Teaching. Nova York: McGraw-Hill, 2003.

Task-based Language Teaching. Cambridge: Cambridge University Press, 2004.

OLIVEIRA, O. C. de. Elementos da estrutura do texto da reportagem. Tese (Doutorado em Comunicação). 1991. 324 f. ECA, USP, São Paulo,1991.

PERINI, M. A. Sofrendo a gramática: ensaios sobre a linguagem. $2^{\mathrm{a}}$. ed., São Paulo: Ática, 2005.

PERRENOUD, P. Avaliação: da excelência à regulação das aprendizagens - entre duas lógicas. Porto Alegre: Artmed, 1998. 
PIAGET, J. A formação do símbolo na criança: Imitação, jogo e sonho, imagem e representação. Rio de Janeiro: Livros Técnicos e Científicos, 1990.

PLATERO, L. G. Is the book still on the table? Considerações sobre o ensino-aprendizagem de línguas estrangeiras no Ensino Médio: uma experiência pedagógica em Língua Inglesa. Dissertação (Mestrado em Educação). 2000. 115 f. FEUSP, USP, São Paulo, 2000.

POSSENTI, S. Por que (não) ensinar gramática na escola. Campinas: ALB/Mercado de Letras, 1996.

REIMES, A. Techniques in teaching writing. Hong Kong: Oxford American English. 1983.

RICHARDS, J. Context of language teaching. Cambridge: Cambridge University Press, 1989.

RICHARDS, J.; RODGERS, T.S. Approaches and methods in language teaching. $2^{\mathrm{a}}$ ed., Nova York: Cambridge Language Teaching Library, 2001.

RINVOLUCRI, M. Grammar Games. Cambridge: Cambridge University Press, 2004.

RIVERS, W.M. Speaking in many tongues: essays on foreign language teaching. Cambridge: Cambridge University Press, 1983.

RIXON, S. How to use games in language teaching. Hong Kong: Macmillan Publishers Ltd., 1985.

RODRIGUES, L.de A. D. Dos fios, das tramas e dos nós: a tessitura da rede de crenças, pressupostos e conhecimentos de professores de inglês que atuam no Ciclo I do Ensino Fundamental. Tese (Doutorado em Educação). 2005. 172 f. FEUSP, USP, São Paulo, 2005.

SANTA, M. P. dos S. Espaços lúdicos: brinquedoteca. In: Santa, M. P. dos S. (org.) Brinquedoteca: a criança o adulto e o lúdico. Petrópolis: Ed. Vozes, 2000, p. 57 - 65.

SCHNEUWLY, B.; DOLZ, J. et alli . Gêneros orais e escritos na escola. Campinas: Mercado de letras, 2007.

SEMEGHINI-SIQUEIRA, I. (coord.) SÃO PAULO (Estado) Secretaria de Estado da Educação. Coordenadoria de Estudos e Normas Pedagógicas. Subsídios para a Implementação do guia curricular de Língua portuguesa para o $1^{\circ}$. Grau: $4^{\text {a }}$ série. São Paulo: SEE/CENP/DRHU, 1977. 
SEMEGHINI-SIQUEIRA, I. Avaliação diagnóstica da capacidade de uso da língua pelo aluno do $1^{\circ}$. grau e a formação do professor. In: Anais. I Congresso de Ciências da Educação. Araraquara/São Paulo: UNESP/USP. 1997.

O peso das práticas educativas de gramática, redação e leitura para alunos do primeiro grau em português: um estudo exploratório a partir da década de 50 . In: Anais. II Congresso Luso-Brasileiro de história da Educação. São Paulo: USP, 1998.

Grade para mobilizar a percepção do professor e desencadear o processo de Avaliação Diagnóstica e Formativa [ADeF] concernente à produção escrita [PE]: conhecimento do grau de letramento/literacia do aluno como estratégia para a reinvenção de práticas educacionais de linguagem. São Paulo: USP Faculdade de Educação, 2002.

Subsídios teóricos para a construção de Sequiências Didáticas em diferentes disciplinas envolvendo gêneros e tipos de discursos: em foco o descrever, o explicar e o argumentar. São Paulo: [versão mimeo], 2001.

O poder do passado nas práticas escolares de oralidade, leitura

e escrita contemporâneas: reconstituição de alicerces para otimizar o grau de letramento/literacia de jovens brasileiros. In: Anais/Actas. XIV Colóquio da AFIRSE "Para um balanço da investigação da educação de 1960 a 2005”. Lisboa: Universidade de Lisboa/ FPCE, 2006 a.

I. Modos de ler textos informativos impressos / virtuais e questões sobre memória: estratégias para alavancar a construção do conhecimento em diferentes disciplinas. In: Rezende, N.; RIOLFI, C.; SEMEGHINI-SIQUEIRA. Linguagem e Educação: implicações técnicas, éticas e estéticas. São Paulo: Humanitas, 2006b.

SEVERINO, A. J. Metodologia do Trabalho Científico. São Paulo: Cortez: 1996.

SOARES, M. Português: uma proposta para o letramento. Manual do professor. São Paulo, Moderna: 1999.

STERN, H.H. Fundamentals Concepts of Language Teaching. Oxford: Oxford University Press. 1991.

TELLES, E. de O. O verso e o reverso das relações escolares: um olhar de gênero sobre o uso dos tempos em uma escola municipal da cidade de São Paulo. Dissertação (Mestrado em Educação). 2005. 210 f. FEUSP, USP, São Paulo, 2005.

TRAVAGLIA, L C. Gramática e interação: uma proposta para o ensino de gramática no 10. e 2o. graus. São Paulo: Cortez, 1996. 
UR, P. Grammar practice activities. Cambridge: Cambridge University Press, 2001.

VYGOTSKY, L. S. O papel do brinquedo no desenvolvimento. In: Formação Social da mente. São Paulo: Martins Fontes, 2003, p. 121 - 137

WASSERMANN, S. Brincadeiras sérias na escola primária. Lisboa: Horizontes pedagógicos, 1990.

WIDDOWSON, H. G. Aspects of language teaching. Oxford : University Press, 1990, p. $215-228$.

WITTGENSTEIN, L. J. J. Investigações Filosóficas. Os Pensadores. São Paulo: Victor Civita, 1975.

WRIGHT, A.; BETTERIDGE, D.; BUCKERBY, M. Games for Language Learning. 12a . ed., Cambridge: Cambridge University Press, 1993. 


\section{REFERÊNCIAS WEBGRÁFICAS}

BARBOSA, R. S. A mulher do coelho. Disponível em: $<$ http://www.aldeiaplanetaria.com.br/astro-sintese/Rsuarez01.htm $>$ Último acesso em $\underline{10 / 12 / 2006}$.

BROUGÈRE, G. Some Elements Relating to Children's Play and Adult Simulation/Gaming. Sage Publications, In: Simulation and gaming, Vol. 30 No. 2, p. 134-146, Junho, 1999, Disponível em: <http://sag.sagepub.com/cgi/content/abstract/30/2/134> Último acesso em 15/12/2007.

BARROS, R. A prova do que funciona. In: Revista da Educação, edição 113, abril 2006. Disponível em: <http://revistaeducacao.uol.com.br/textos.asp?codigo=11930> Último acesso em 15/10/2006.

FOGAÇA, F.C.; GIMENEZ, T. N. O ensino de línguas estrangeiras e a sociedade. In: Revista Brasileira de Linguiística Aplicada, v. 7, n. 1. UFMG: Minas Gerais, 2007. Disponível em: $<$ http://www.letras.ufmg.br/rbla/2007 1/08-Francisco\%20Foga\%E7a\%20et\%20al.pdf $>$ Último acesso em 11/01/2008.

KANIKADAN, A.Y.S.; LIMONGE-FRANÇA, A.C. Entendendo a qualidade de vida no contexto de trabalho em uma escola de idiomas. Disponível em: $<$ http://www.ead.fea.usp.br/Semead/6semead/RH/037RH\%20Entendendo\%20a\%20Qualidad e \%20de\%20Vida.doc > Último acesso em 20/01/2008.

KARSHEN, S. Second language acquisition and second language learning. Nova York: Pergamon Press, $1981 . \quad$ Disponível em:

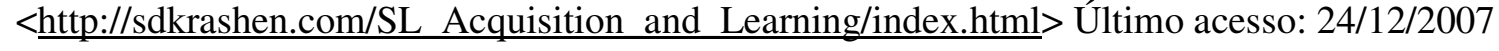

LIMA, J. G. Falar e escrever, eis a questão. Revista Veja, São Paulo, edição de 07 janeiro 2001. Disponível em: <http://veja.abril.com.br/071101/p_104.html> Último acesso em $12 / 04 / 2007$.

OXFORD, R. Task-Based Language Teaching and Learning: An Overview. In: The Asian EFL Journal Quaterly: Special Conference Proceeding Volume - Task-based Learning in the Asian Context. Set. 2006, Vol. 8. p. 94 - 121, Ilhas Virgens Britânicas: Asian EFL Journal Press, 2006. Disponível eletronicamente em:

$<$ http://www.asian-efl-journal.com/September_2006_EBook_editions.pdf $>$ Último acesso: 24/12/2007.

PISA, 2000. Disponível em:

$<$ http://www.inep.gov.br/download/internacional/pisa/PISA2000.pdf $>$ Último acesso em $4 / 09 / 2007$. 
PROVA BRASIL, 2005. Disponível em:

$<$ http://www.inep.gov.br/basica/SAEB/prova brasil/escala_port.htm>Último acesso em $4 / 09 / 2007$

SAEB, 2003. Disponível em:

$<$ http://www.inep.gov.br/download/SAEB/2004/resultados/BRASIL.pdf $>$ Último acesso em $10 / 10 / 2006$

SARESP, 2004. Disponível em: <http://www.educacao.sp.gov.br/> Último acesso em $10 / 10 / 2006$.

TÓFFOLI, D. O ensino municipal de São Paulo está entre os sete piores do país. Disponível em: <http://www1.folha.uol.com.br/folha/educacao/ult305u18791.shtml $>$ Último acesso em 11/09/2006. 
ANEXOS

\section{Anexo A - Programa de Português (escola onde ocorreu a Primeira Entrada em campo)}

\section{Programa de Português}

$7^{\circ}$. Ano do Ensino Fundamental - Turma ABCD

1. Objetivo geral do bimestre: Desenvolver estratégias de leitura tornando-a eficiente; comparar textos percebendo semelhanças e diferenças quanto ao gênero e às idéias; debater sobre os temas propostos pelos textos, desenvolvendo habilidades de expressão e argumentação oral e escrita, aplicando os conhecimentos gramaticais, semânticos e estilísticos, estruturados com nível adequado de linguagem, organização, qualidade, pontualidade.

2. Objetivos específicos:

2.1. Reconhecer a notícia como gênero e produzi-la empregando, com propriedade, os recursos pertinentes a essa tipologia textual;

2.2. Conjugar e aplicar em diferentes contextos, os verbos irregulares no modo Indicativo e Subjuntivo.

2.3. Apropriar-se e fazer uso adequado das regras de acentuação da palavra.

2.4. Ler efetivamente, compreender e interpretar textos variados, inclusive a obra paradidática escolhida. 
Anexo B - Código de correção de Língua Portuguesa (escola onde ocorreu a Primeira Entrada em campo)

Código de correção de Língua Portuguesa:

A: acentuação

O: ortografia

M: Maiúscula

PR: palavra repetida

CV: concordância verbal

$\mathrm{P}$ : pontuação 
Anexo $C^{116}$ - Produções dos alunos que participaram da Primeira Entrada em Campo - produções em inglês

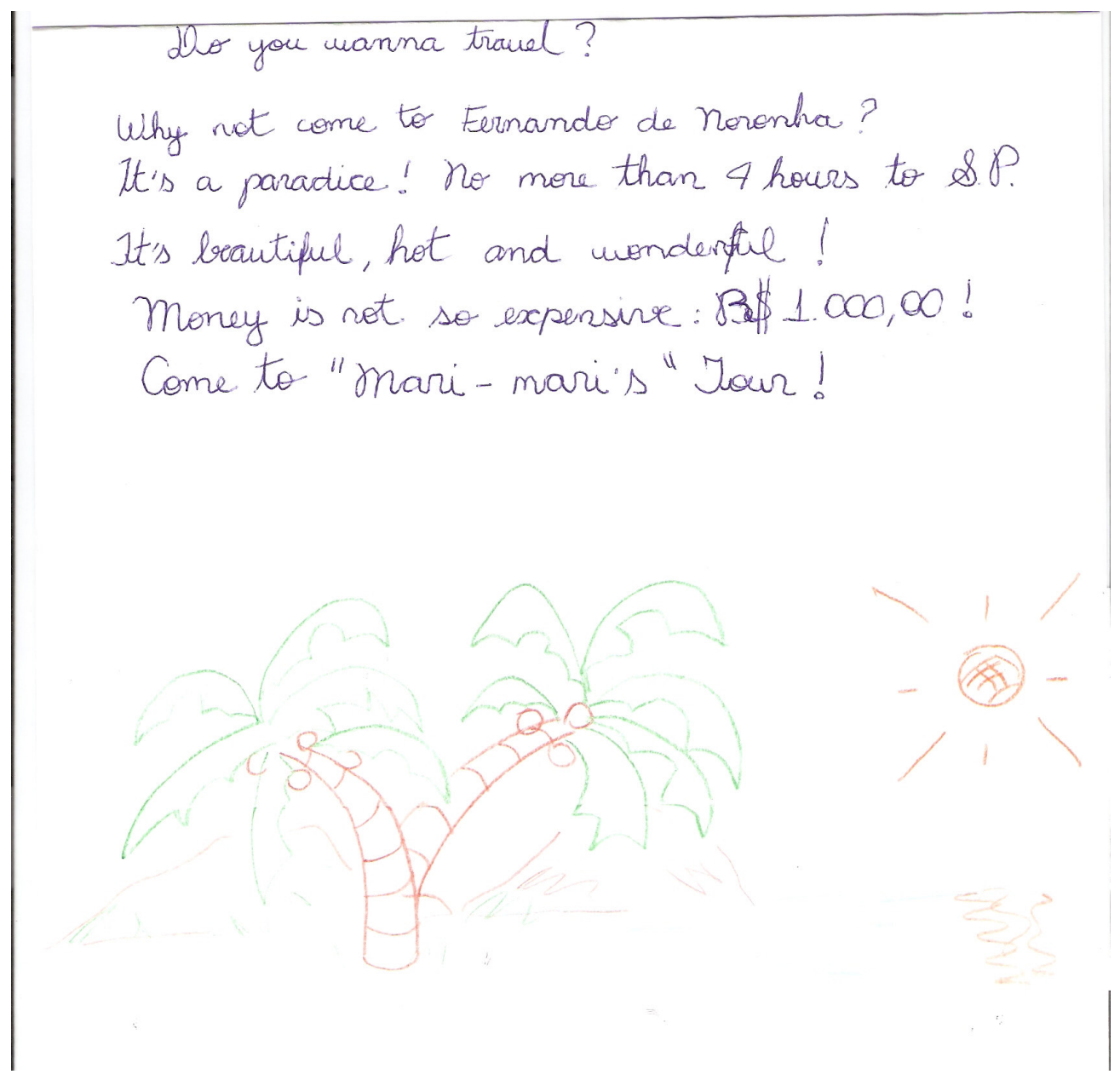

${ }^{116}$ Infelizmente, das 4 produções coletivas realizadas, a pesquisadora obeteve a permissão de cópia de apenas 3. 
233

city Parati

There are places indescribable
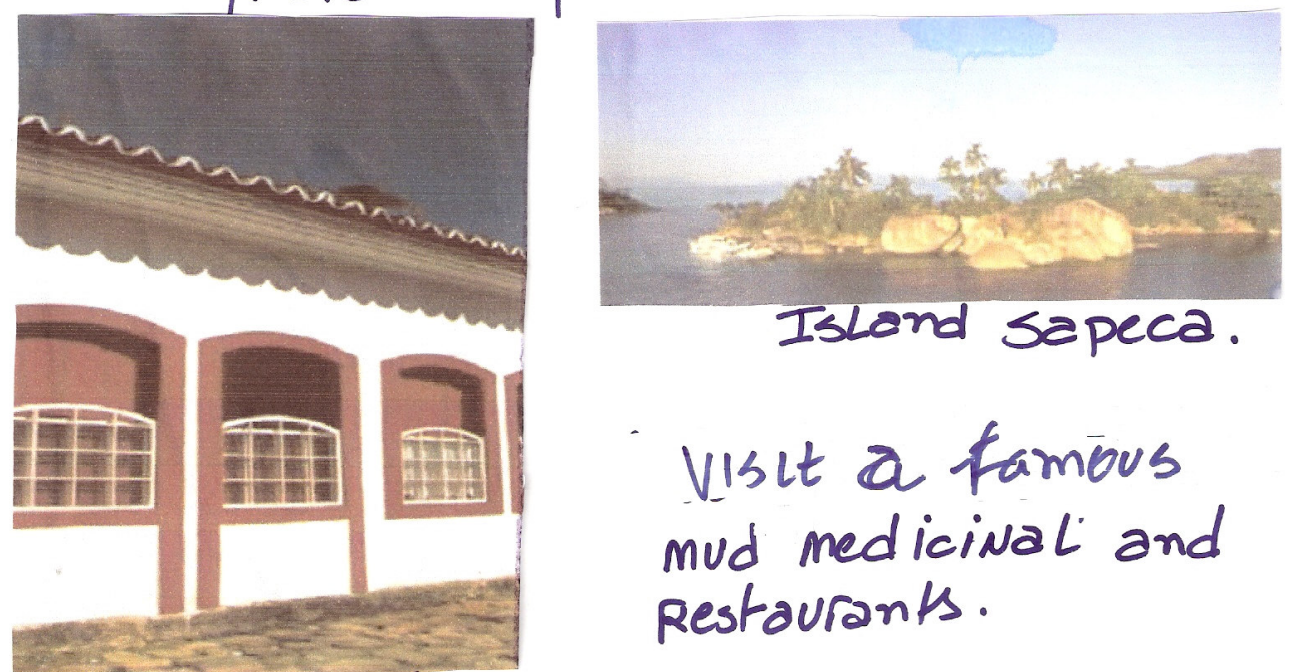

Visit a famous mud medicinal and Restaurants.

The street were bundt by slaves.

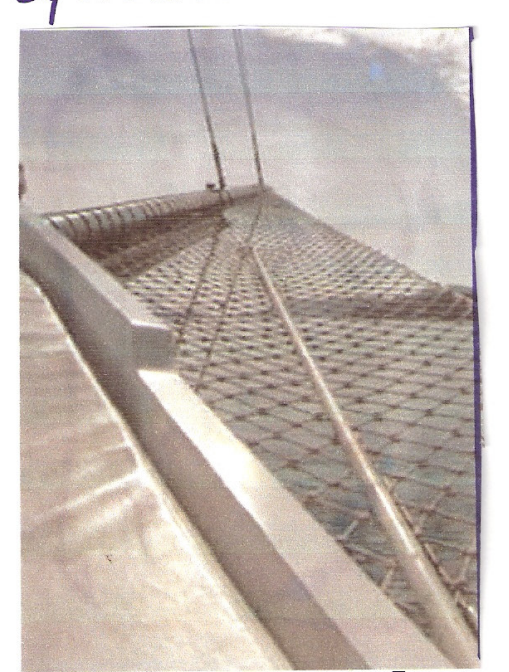

The parcel to one week \$250,00 with bed glbraksst

Reserve by:

Fore (021) 3333-5758

fax (021) 3333-1275.

email: cutyparatiloterra. com. BR website: ww coly ssliand.org

shift see arg of
BOAT. 

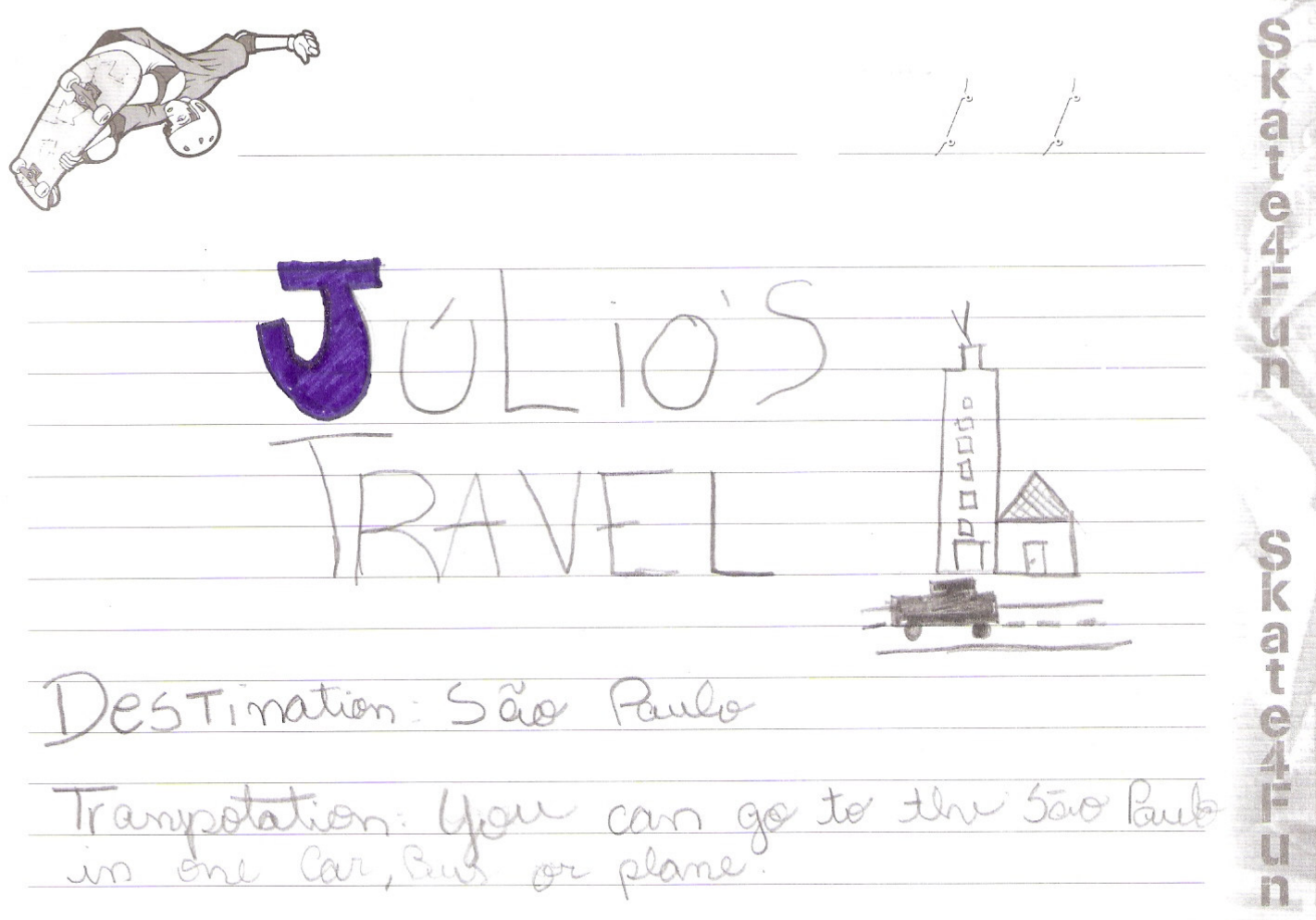

Descripition of the place: Sä Paulo is one city very movimest, very proples

Were to stay You stay in woteles. Hilton, Holiby tim and cifunich

Length of thay: You in stay 10 days, because in saco poubo not vary tering of to make.

Why war want there toun to a ther blaause there are a lot of historis places, musiem, theater and oder

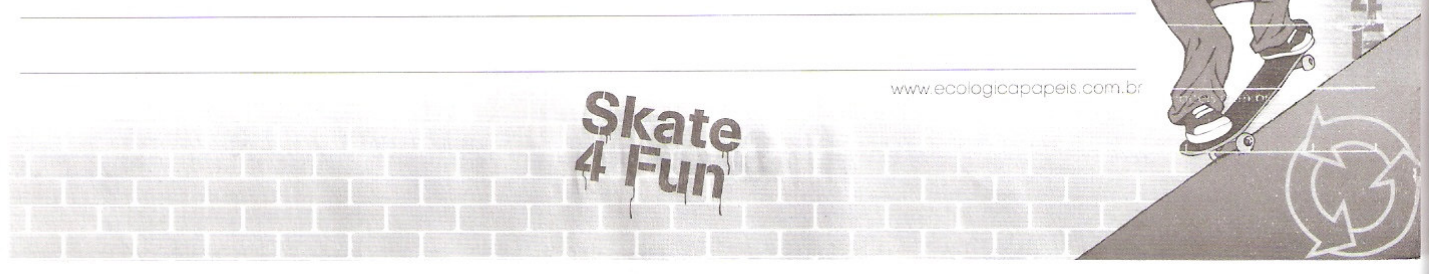




\section{Anexo $D^{117}$ - Produções dos alunos que participaram da Primeira Entrada em Campo - produções em português}

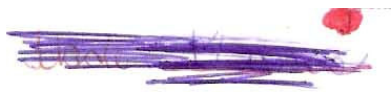

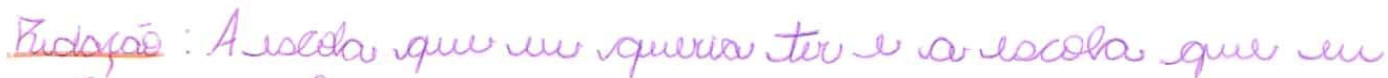
naó queria; 1 professor que ur queria ter 2 o que en now queria.

Teriar que ter bons professores en boas materias, o aluno teria qui passar com sew usforpo, e nā pasoar só por passar. Teria que ter salas de vídeo, sulas de enfermagem, lvara quev ler enfermagem na iscola teria que ter alunos interedsados em aprender, teria que sev limpa, com uma low higiên, com salos maiores es com minos alunos, para se podve estwdar mellor. A lacola que en ná queria ter í tudo o que un disse mas aou contrário.

- propsoor que un queria ter éaquele que sali lidar com os adunos, que os unsina, que so intende er que e'sue vamigo. Ra verdade, um professor l' como um pai no maioria dav vezes, nós, alunos, porsarmos a maior parte slo nosso tempo na esciola.s. - Oprofessor tem que saber a hora de ensinar e de entender a aluno, esse l'o bom aluno.

${ }^{117}$ Estas produções foram coletadas em momento posterior ao de aula (durante o intervalo), quando 4 dos 11 alunos-sujeitos da pesquisa se dispuseram a responder duas questões, por escrito, à pesquisadora: 1. como seria a escola de seus sonhos; e 2. como seriam os professores de seus sonhos. Optou-se por este material porque a pesquisadora não obteve acesso para fotocopiar as produções de sala de aula desses alunos. 
Un bom popsoso e um mal professen... uma boa excola a uma máesteda....

IIm bom poofesson ra minha opiniás, $e^{-}$ aquel our se entivisa em endinon bem ensi

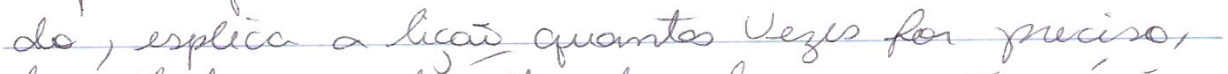
tró todes as divides do aluno $e$ nas só $l^{-}$ servo \& vaido mais sinpatico, bussicalharm, prondo respute, mais divertide.

fá um" mal professor $i$ - aquele que ńa uspeite as opinsiaes des alumos, nas os resputos, nas esplica dirieito a mative an explicia de qualquen futo, $l^{-1}$ sempre "azedo", malmerado, bravo e náó tere sempri todos as nosses dúvides, pancs ate' que nas gosto do que fag.' Un excola boa l' aquela que tem uma boa lidenança t ums bons alunos, limpa, 1 bem organizada, com ótimos emprugados. fá uma inola nuim, it escuna, sem orga nuzacas, com prísimos professores, dirigà persima, furrcionsanos malcivados l sem telucagas on uspitto.

Bom, Avem foz à excola das os alunos, mos es professouse toodos que Trabalham nela eso afuida a incentiven on alusos.

\section{Jim! !}

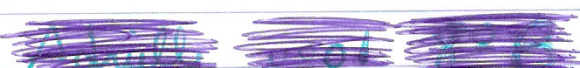


237

A ebcola que eu quenia teeiz a escola que eu van quería; O projessor que eu quería ter eo que eu nou queria.

escela quando falamos em ebcola persamos em trabalhe Licón de caba ell mas escola nóe pectic SeR jo ibso por noos blunom non pendomon 0 interesse de escudor a escola dos sonhos nóa pocte ser so kicón te Erobollno mas sim Alulai de tentro polestian eventos culturais A elciola que du não queria. e- a escola que o professor vás entende do Acuno nós procura saber es problemas para Aludar no soa caminhode doirear i egcola ym ORdem ter Un Limite

U professo tep que sem Amigo do tluno Afodor É Alvino ORienta-lo noo bopOSSOR A malckir se vira e cque Aconfece Heje professon que so' Recebe sei que e michoria 
238

Anexo E - Avaliação Diagnóstica e Formativa (ADeF) recolhida na Segunda Entrada em Campo

Professora a qui quim lala e co un adorei a sremeive dia de alle for mito empreatianto para him cyprondir farias cceisas inda bem que t' a primairo dia que fosse ce utimeo en estaria muito chatiado par a re soóno primeirce dia ell aprendir muitas ceisas quardio fa'os contros en acho que vai si meldo en tavo aqui veer deichar uma marquinha.

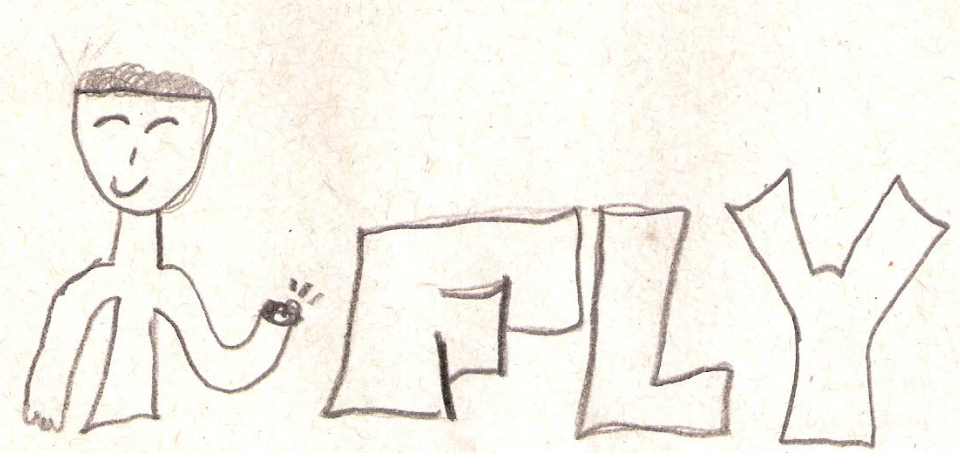


239

* Professora Andría gostir muto De Vocé adorei muito Sua lrincadira Vocè é $10 \%$ lecgal simpatica Vocé éA Pessoo. aie en if wir * Super legal.
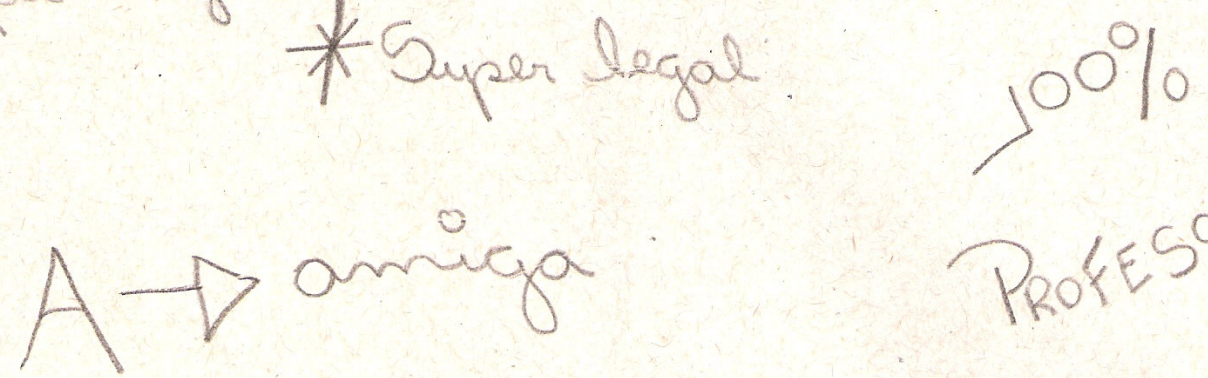

$$
\text { Prokessora }
$$
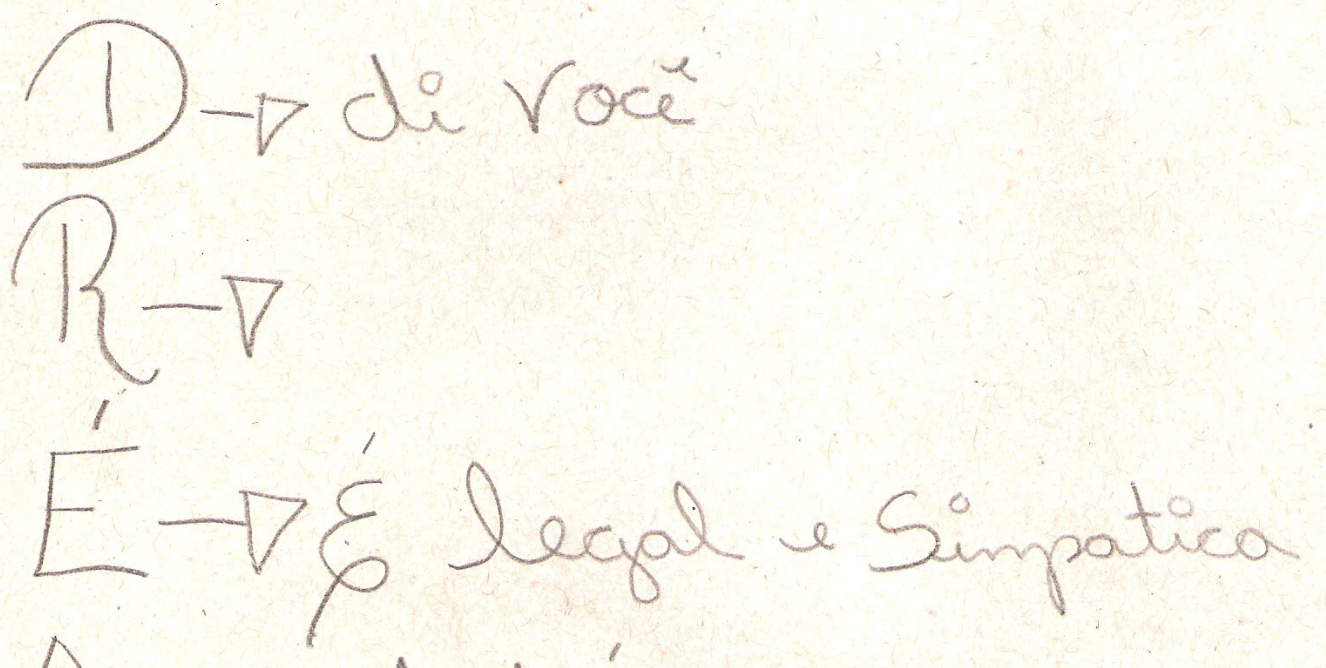
$\Delta-\Delta$ Andréa 
$01 / 11 / 2006$

$D a=$ sese

$$
\text { para- Andréia }
$$

Professora un gottei muito de rocè, rrocê í Super legal, é criatirra, educatirra, it simpática, eu Te Pais, mu nome i karine, sou rasca mim Eu gosto muito da mínhas a l adoro meus

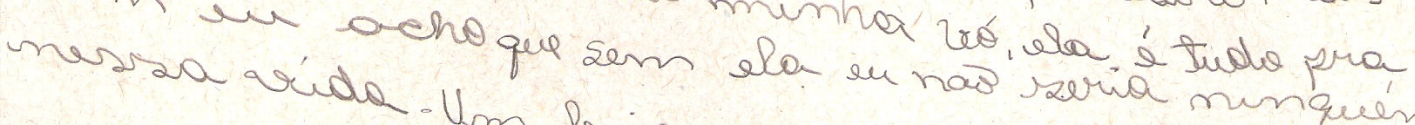
-Um lrujo nunquém

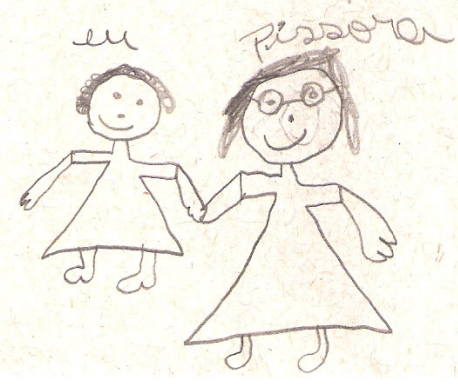




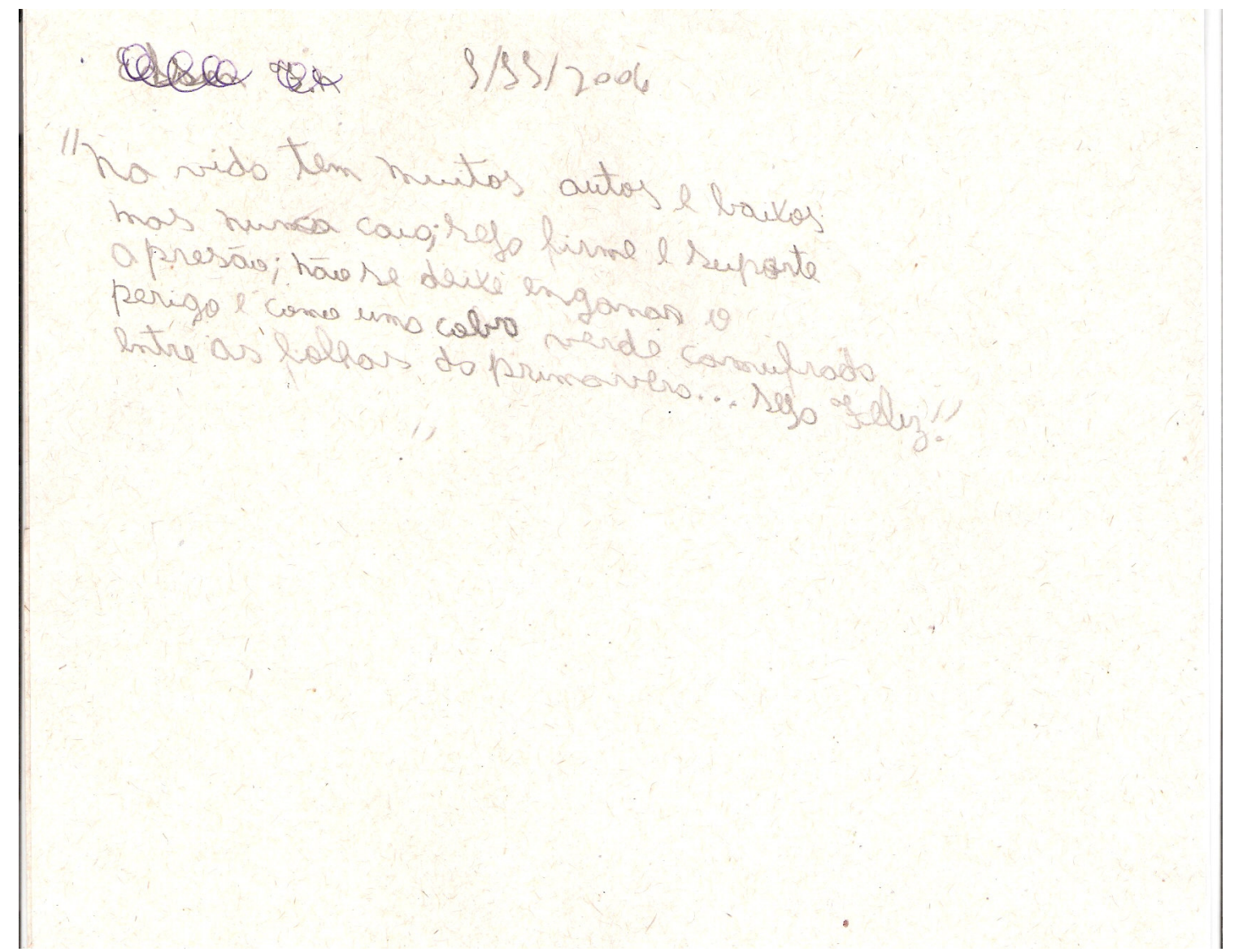




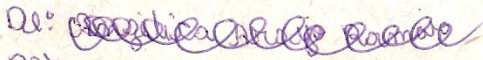

para indréa kalante carta

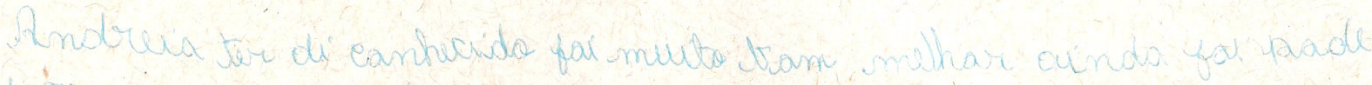

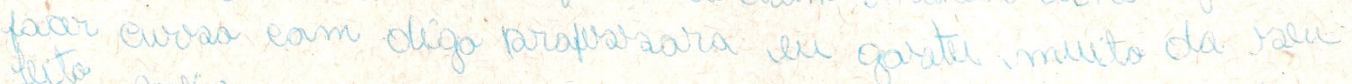

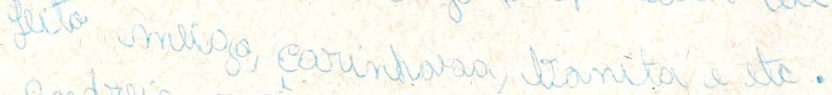

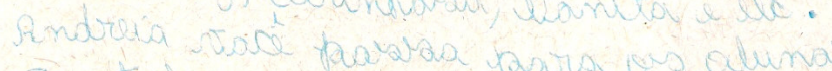

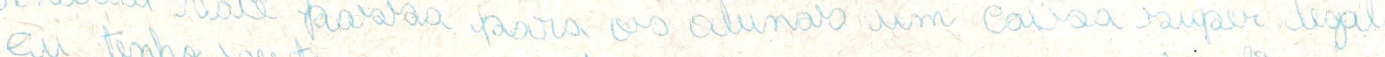

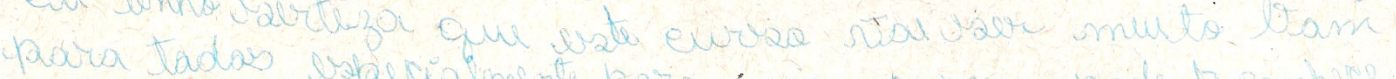

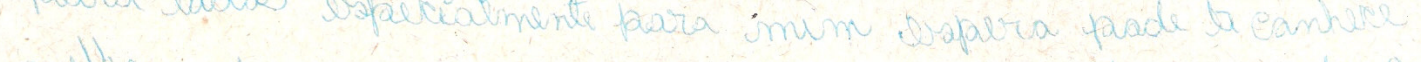

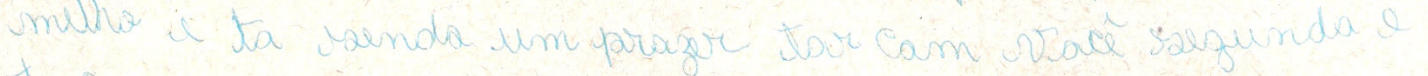
forca.

$\int+>\operatorname{somiga}$

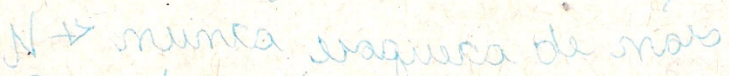

$D \rightarrow$ de hace

$R \rightarrow$

$C \rightarrow$ llogounte

$\rightarrow \rightarrow$ In

A Amararala: 


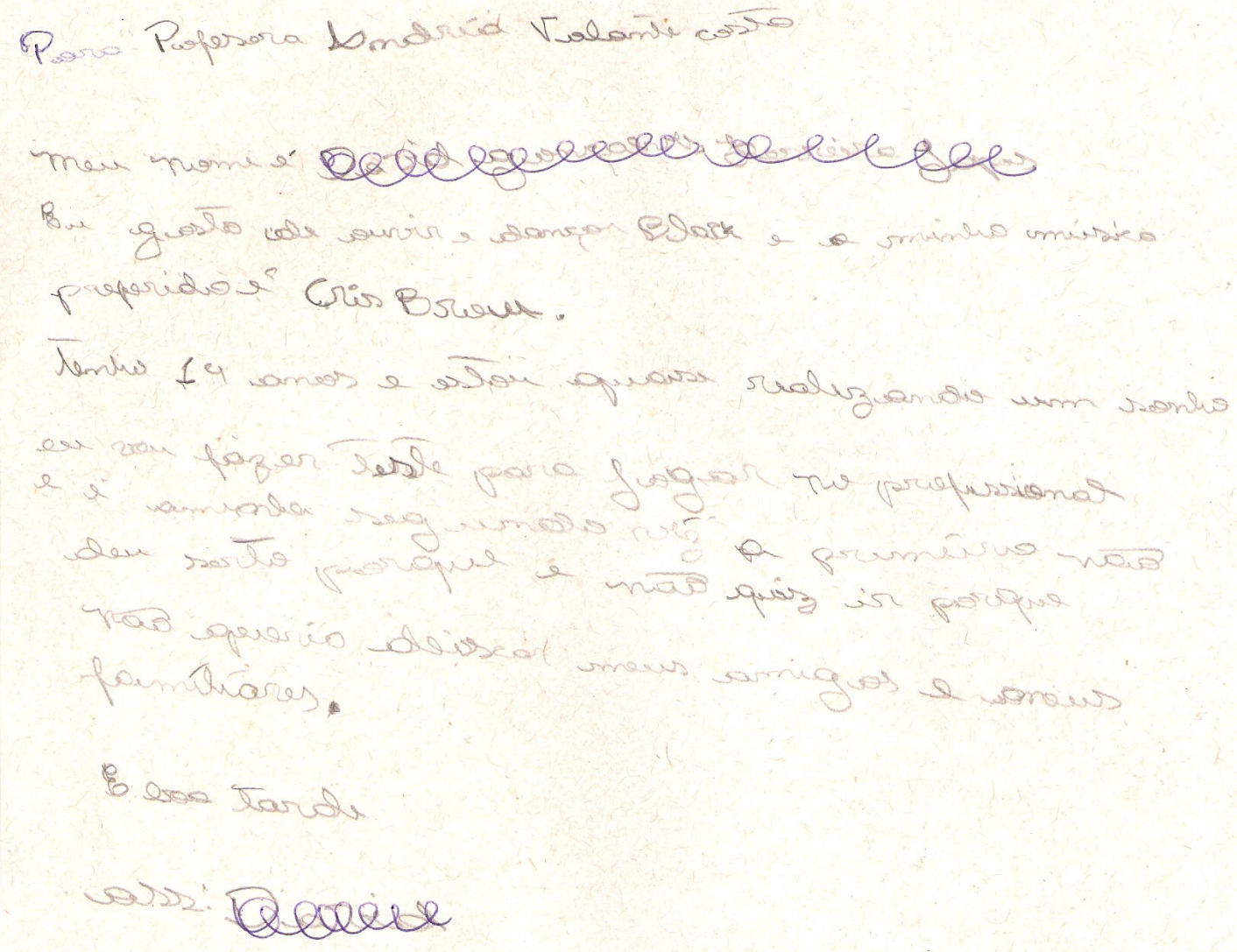


244

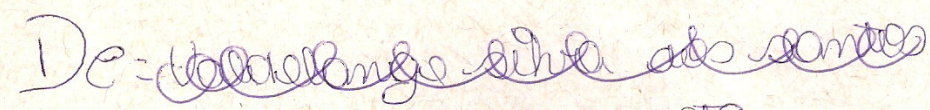

para-Ononeiá volante rosta.

Ce imeu unome valálelangy, eu tentw 14 anos sstou una b seril uninha comiolo preforida $\varphi$

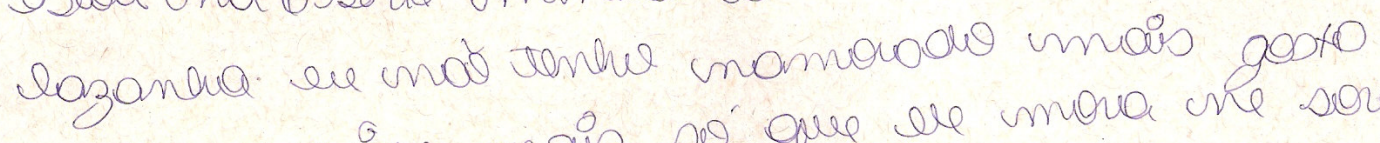
de um meninu mais so que le mora one sou - cona a unome ade e inorilos.

professora en gosuli mivita da sonhorita a senchora e cmuito legal muito fontil minuto enteligonte Bonito smpatica tudur que for of Bom a pona voke

he quando de cresor en aume ser propposona su veteriunoria.

bom proplessora er aneres que vole? sejo invito feliz com seu unari do a que vocés toyo bostonte fiehos.

$$
\begin{aligned}
& \text { bejos } \\
& \text { do vol }
\end{aligned}
$$

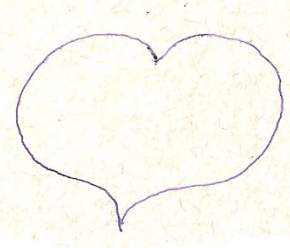


Gosti da profesola fol que cLa é LEGAL Ri OA MINHA MAE MARLEU llo thenlli lon qua foi ontoxka do Pelos turis tis o MinllA Vo vendar dos deda do tés 


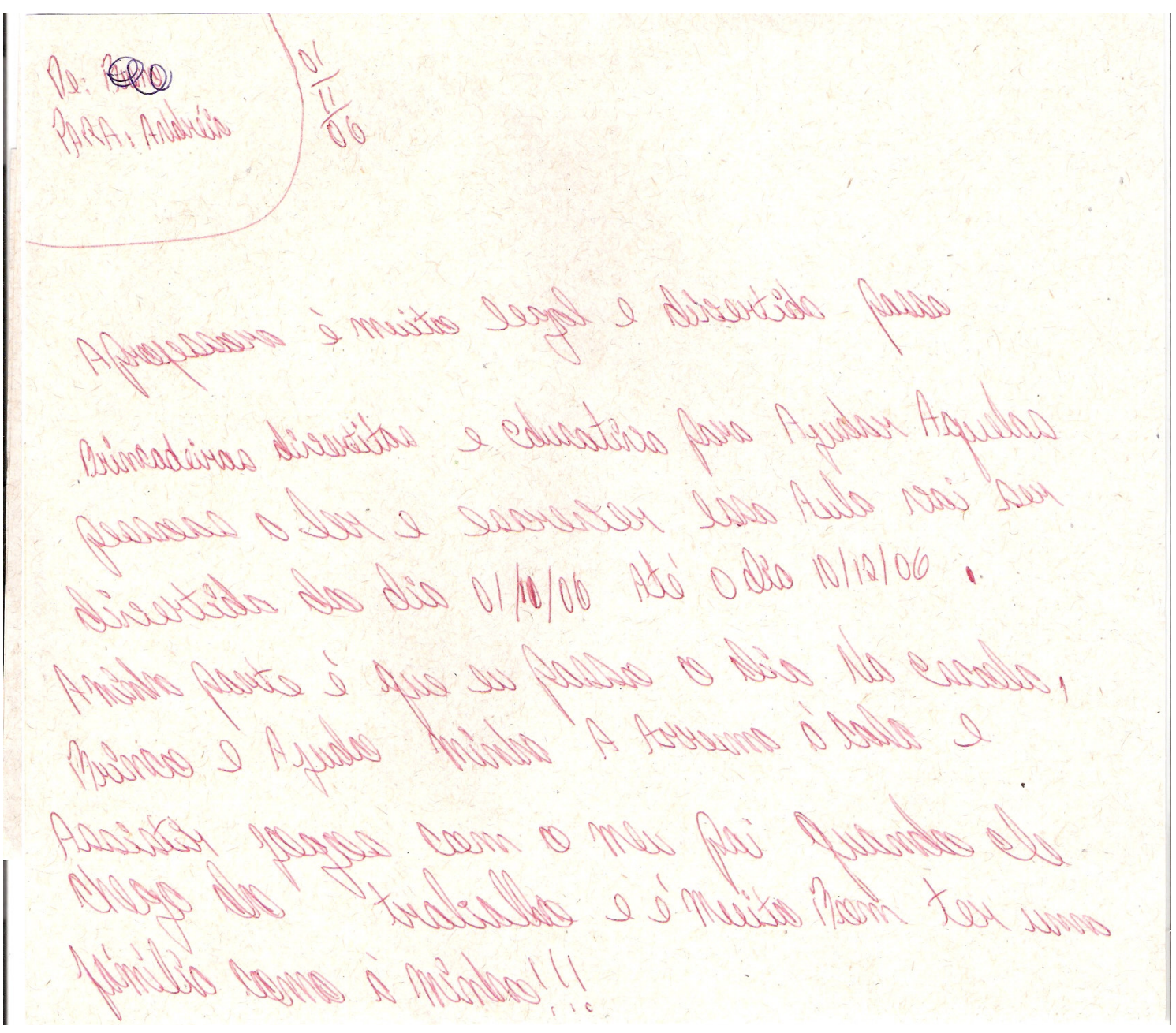




\section{GRADE para mobilizar a percepção do PROFESSOR e desencadear o processo de AVALIAÇÃO FORMATIVA [AF] concernente à PRODUÇÃO ESCRITA [PE]: conhecimento do NíVEL DE LITERACIA do ALUNO como estratégia para a reinvenção de práticas educacionais de LINGUAGEM USP - Faculdade de Educação - Docente: Prof ${ }^{a} r^{a}$ IDMÉA SEMEGHINI-SIQUEIRA, lingüista}

[versão: 20.10.2002]

Colega PROFESSOR(A)! Convido-o(a) a ler, inicialmente, todos os grandes tópicos para ter uma visão geral desta grade A seguir, solicito que realize outra leitura para conhecê-la em detalhes. Informo que, para cada página desta grade, haverá una folha "sem texto" que viabilizará a análise das produções escritas. Após a AVALIAÇÃo PRELIMINAR, no item 1.14., você terá 4 "pilhas" de PE. Retire, ao acaso, uma PE de cada "pilha". Você usará esta grade com 4 PE. Bom trabalho!!!

No alto da folha "sem texto", sobre cada coluna, colocar [número/ NOME do ALUNO / idade], por ex: $\rightarrow$ [01/ANA / 11a]

\section{AVALIACAO TREI MMNAR IAPI do professor}

(1.ggo apos realizar a prineira lemura da produrgao escrita do alino, o professor registra a AP)

1.1. Produção escrita: individual [PEI] ou em grupo [PEG]

1.2. Contato prévio do professor-avaliador com o produtor do texto: conhecido [Alu-CO]; desconhecido [Alu-DES]

1.3. Edição (ou qual a versão da PE ?): única versão [UV]; passada a limpo [PL]; reescrita [REE] [reescrita como construção / processo em que o aluno aprende a olhar o texto como objeto transformável]

1.4. A topografia da página ou os saberes sobre a organização não-verbal são adequados ao GÊNERO ? [Por ex: se a PE for carta / bilhete, contém todos os elementos dispostos etc.] sim [S]; não [N]; em termos [ET]

1.5. Este texto foi escrito de maneira legível ? $\operatorname{sim}[\mathrm{S}]$ não [N] em termos [ET]

1.6. Do que trata esta produção escrita? [uma palavra-chave]

1.7. Esta produção escrita requer título? $\operatorname{sim}[\mathrm{S}]$ não [N]

1.8. Houve adequação na escolha do título? sim [S] não [N] em termos [ET]

1.9. Qual interlocutor o aluno tinha em mente ? Escreveu para quem ler? Leitor fictício $=$ [LF] Leitor real: colega [LR-Co]; professor [LR-Pr]; pesquisador [LR-Pes]; outro LR:

1.10. Sobre o grau de investimento na escrita pelo aluno. Você considera que este aluno se empenhou para produzir um texto adequado? $\operatorname{sim}[\mathrm{S}] ;$ não [N]; em termos [ET]

1.11. De um modo geral, ao se expressar por escrito, o aluno atingiu o objetivo ? Sim [S]; não [N]; em termos [ET]

1.12. Se houve a especificação đe um GÊNERO pelo professor, a produção escrita está adequada à proposta ? Sim $[S]$ กão $[N]$ em tcrmos [ET]

1.13. Principal problema detectado?

1.14. Nesta avaliação preliminar, em que categoria esta PE poderia ser classificada ? Plenamente Satisfatória [PS]; Satisfatória [SA]; Razoavelmente Satisfatória [RS]; Não Satisfatória [NS]

1.15. Outra observação:

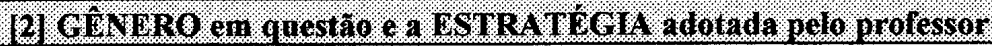

2.1. SEM trabalho prévio pelo professor: o gênero é opção do aluno [G-opA] ou é proposto pelo professor [G-pPr]

2.2. GÊNERO TRABALHADO previamente pelo professor no processo de Avaliação Formativa [G-trab]

2.2.1. A produção escrita está adequada ao gênero trabalhado? sim [S]; não [N]; em termos [ET]

2.2.2. Se a PE estiver adequada ao gênero trabalhado, pode ser considerada: [PS]; [SA]; [RS]

2.3. Após analisar a "TIPOLOGIA TEXTUAL" da produção escrita, que consta do tópico [4] desta grade ANOTE (tanto para o caso 2.1. como para o 2.2.), qual é o tipo de trecho / sequêência predominante:

narração [NA]; relato [RE]; descrição [DES]; argumentação [ARG]; explicação [EXP], diálogo [DIA]

2.3.1. Se apareceram vários tipos de seqüências, anote o conjunto. [Por ex: RE + DES + EXP]

\section{[3] GENEROS ESCRITOS: agrupamentos a partir de tópicos mais amplos.}

(Localize o gênero em questäo e anote)

3.1 Íntimo/pessoal: bilhete [bil]; carta informal [car]; cartão postal [pos]; cartão de felicitação [fel]; outros:

3.1.1.Interlocutor: amigo [ami]; colega [col]; namorado [nam]; familiares [fam]; outro:

3.1.2. Não houve possibilidade de identificar o interlocutor: [nãol-Int] 


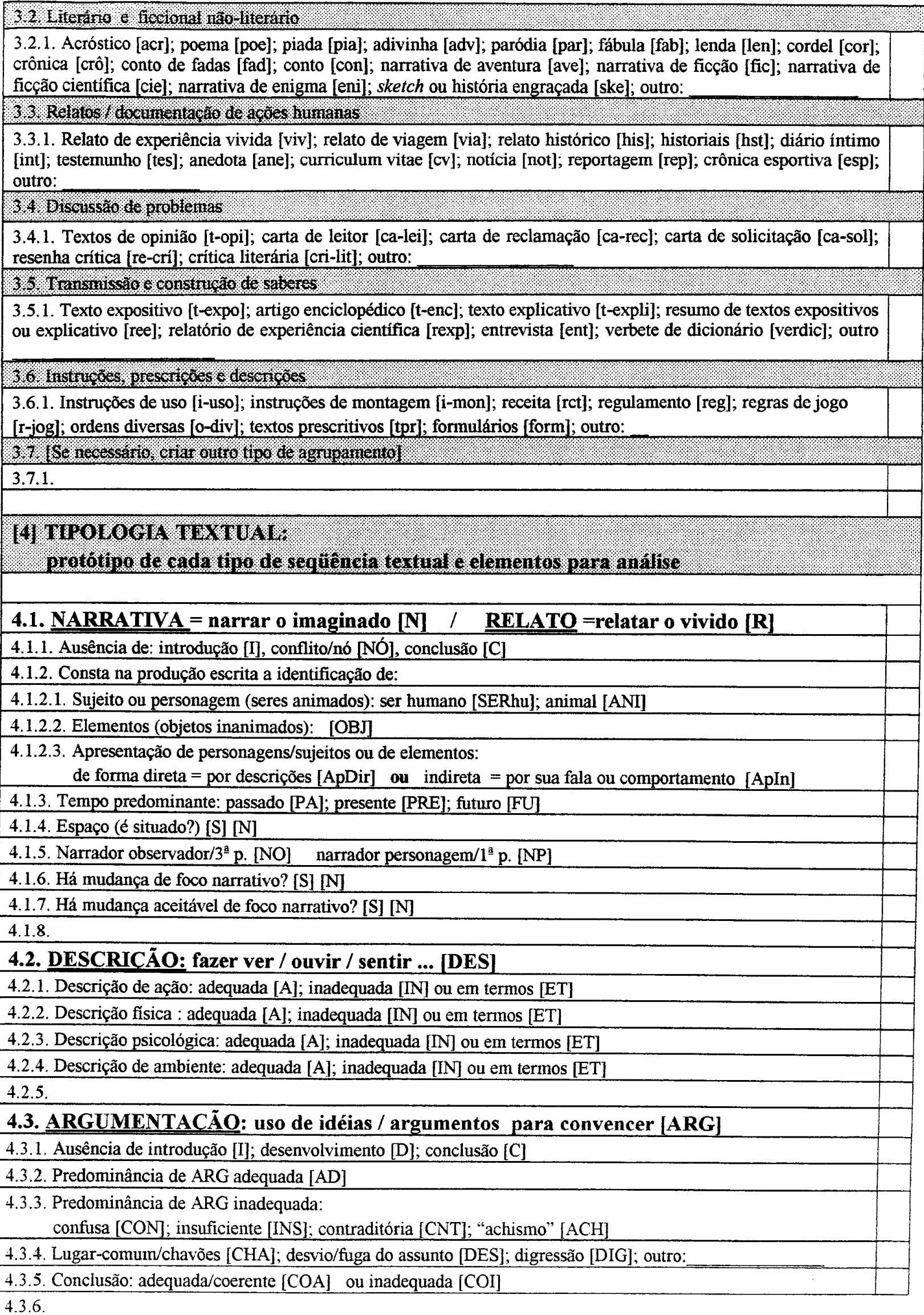




\subsection{EXPLICACÃO: fazer compreender [EXP]}

4.4.1. Ausência de introdução [1]; desenvolvimento [D]; conclusão [C]

4.4.2. Há um problema [PRO] a ser resolvido ou uma questão [QUES] a ser respondida ?

4.4.3. São estabelecidas relações de causa e efeito ? Sim [S] Não [N]

4.4.4. Função especifica: informar [INFO] ou ensinar-fazer [IN-FA]

4.4.5. Lugar-comum/chavões [CHA]; desvio/fuga do assunto [DES]; digressão [DIG]; outro:

4.4.6. Conclusão: adequada/coerente [COA] ou inadequada [COI]

4.4.7.

4.5. DIÁLOGO / CONVERSAÇÃO

4.5.1. Turnos conversacionais. Quantos ? $\left[\mathrm{n}^{\circ} \ldots \ldots . . . ..\right]$

4.5.2. As trocas se apresentam de forma hierarquizada e coordenada ? $\operatorname{sim}[S]$ não $[N]$ em termos [ET]

4.5.3. Na produção escrita, há elementos do contexto que permitem a compreensão dos turnos conversacionais ? $\operatorname{sim}[\mathrm{S}]$ não [N] em termos [ET]

4.5.4.

\section{ORGANIZACAO DO TEXTO: COERENCIA E COESAO}

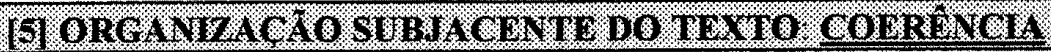

\subsection{Coerência global $[\mathrm{S}][\mathrm{N}]$ [em termos]}

5.2. Incoerências locais $[\mathrm{S}][\mathrm{N}]$

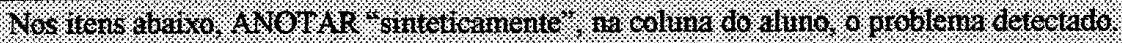

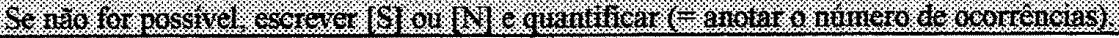

5.2.1. Incoerência semântica (uso inadequado de itens lexicais). Ex.: "executar problemas"

5.2.2. Incoerência sintática. Ex.: "A felicidade, onde não existem técnicas científicas, ..."

5.2.3. Incoerência estilística.

Ex.: "... quero expressar meus sentimentos por sua mãe ter batido as botas."

5.2.4. Incoerência pragmática. Ex.: Se [a] pergunta $\mathrm{X} \mathrm{e}[\mathrm{b}]$ responde $\mathrm{Y}$, como no caso que segue:..

[A]: Você me empresta seu livro? [B]: Hoje eu comi uma pipnca deliciosa

5.2.5. Incoerência referente ao conhecimento do mundo.

Ex.: Quando fui à Europa, visitei as pirâmides do Egito.

5.2.6. Incoerência "estrutural" (período incompleto/truncado)

5.2.7. Incoerência provocada por lacunas (ausência de fatos que deveriam ter sido apresentados)

5.2.8. Outros tipos. Especificar:

\section{ORC. MVA A AO SUPERTICLA, DO MEXTO. COESAO}

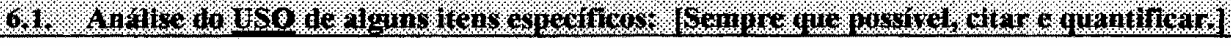

6.1.1. Recursos da ORALIDADE na produção escrita: uso como elemento coesivo.

Ex.: e, então, dai, ai, por falar nisso, etc. [citar e quantificar]

6.1.1.1.

6.1.2. Repeticões [Sempre que possivel, em todos os itens, citar e quantificar]

6.1.2.1. Uso repetitivo de pronomes pessoais do caso reto.

6.1.2.2. Uso de repetição lexical (simples ou complexa). Ex.: amigos/amigas amigo/amizade

6.1.2.3. Uso de repetição por paráfrase. Ex.: verificar/constatar autor/escritor

6.1.2.4. Uso de repetição hiponímica. Ex.: animal/gato

6.1.2.5. Uso de repetição por substituição. Ex.: raça/ela

6.1.3. Conectivos / Conjunções

6.1.3.1. Uso de conjunçóes coordenadas [citar e quantificar]

6.1.3.2. Uso de conjunções subordinadas [citar e quantificar]

6.1.3.3. Ausência de conectivo: aceitável [Co-aus] ; problemática [Co-aus-pro]

$6.1,3.4$ 


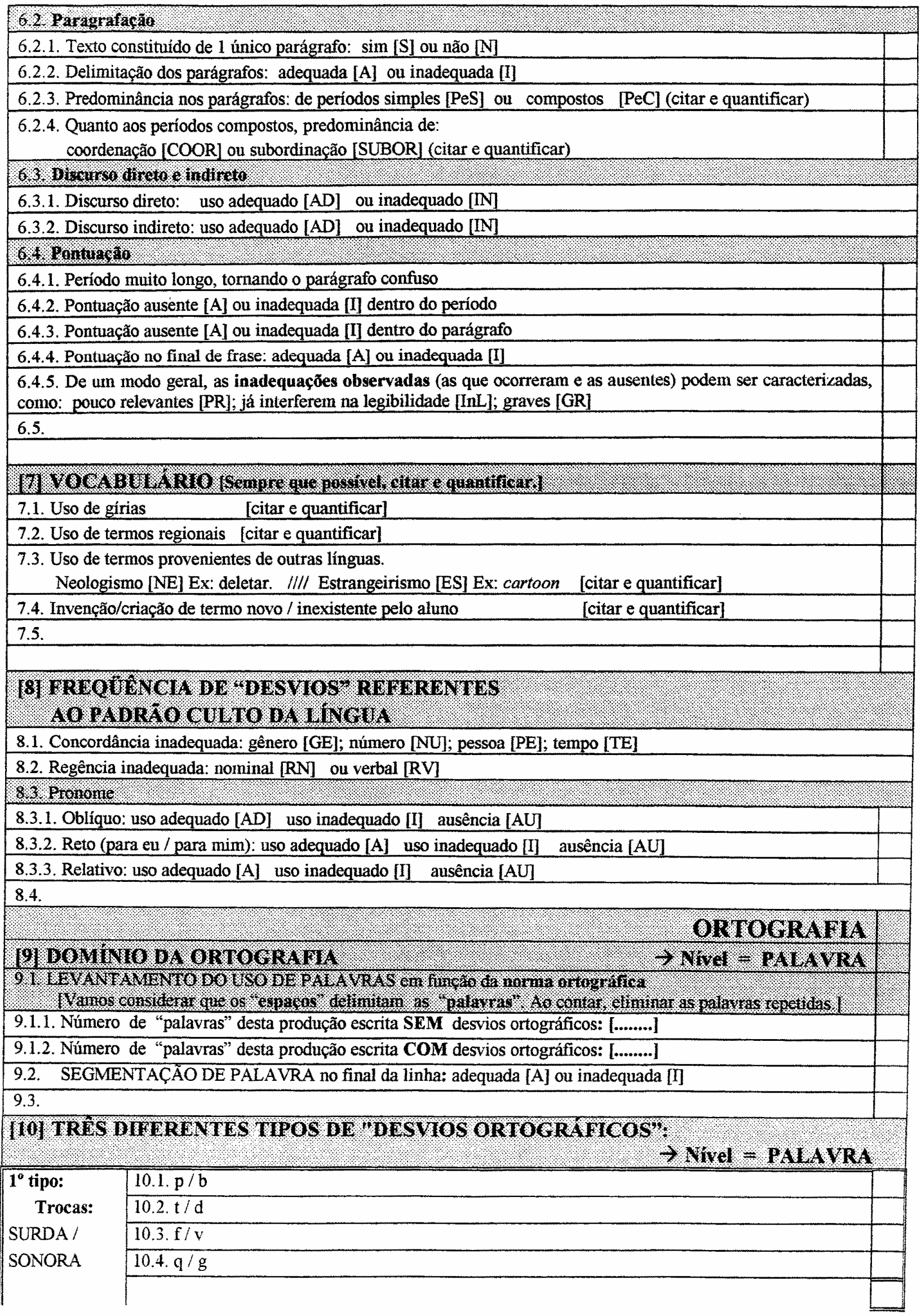




\begin{tabular}{|c|c|}
\hline $2^{\circ}$ tipo: & 10.5. 1/: [probrema] \\
\hline & 10.6. Tho / io \\
\hline & 10.7. $-\mathrm{r} / \varnothing$ \\
\hline & $10.8 \cdot-\mathrm{s} / \varnothing$ \\
\hline & 10.9. am / ẫo / o [falaro] \\
\hline & 10.10. ai / a [embaxo] [mais $\rightarrow$ mas] \\
\hline Interferências & 10.11. ei /e [leitero] \\
\hline da & 10.12. ie / e [pacência] \\
\hline ORALIDADE & 10,13. e / i [minino] \\
\hline [decorrentes & 10.14. - $\mathrm{c} /$-i [lciti] \\
\hline de & 10.15. e/ ei [feiz] \\
\hline variação & 10.16. em / eim [tambeim] \\
\hline linguiistica & 10.17. ou / o [poco] \\
\hline no BRASIL & 10.18. ou/u [truxe] \\
\hline (Estado de & 10.19. o/u [buneco] \\
\hline São Paulo)] & 10.20. - o/ - u [dadu] \\
\hline & 10.21. acréscimo de vogais [adimirou] [peneu] \\
\hline & 10.22. acréscime de elemento de nasalização[muinto] \\
\hline & 10.23. junção de palavras [derrepente] \\
\hline & 10.24. "transcrição fonética" [sescondero] \\
\hline $3{ }^{\circ}$ tipo: & $10.25 \mathrm{j} / \mathrm{g}$ \\
\hline & $10.26 . \mathrm{r} / \mathrm{\pi r}$ \\
\hline & $10.27 \times \mathrm{x} / \mathrm{ch}$ \\
\hline & $10.28 . \mathrm{s} / \mathrm{z}$ \\
\hline & $10.29 . \mathrm{s} / \mathrm{ss} / \mathrm{sc} / \mathrm{c} / \mathrm{c} / \mathrm{xc}$ \\
\hline & $10.30 .1 / \mathrm{u}$ \\
\hline Desvios & $10.31 . \mathrm{lh} / \mathrm{li}$ \\
\hline da & $10.32 . \mathrm{m} / \mathrm{n}$ \\
\hline ORTO- & 10.33. $\mathrm{h}(+$ ou -$)$ \\
\hline GRAFIA & 10.34. Ausência de vogais [advinhou] \\
\hline PADRÃO & 10.35. Ausência ou uso inadequado de elementos de nasalização [vederam ou vëderam]] \\
\hline no BRASIL & 10.36. Ausência de silaba na palavra \\
\hline (Estado de & 10.37. Acentuação: ausência \\
\hline São Paulo) & 10.38. Acentuação: uso inadequado \\
\hline & 10.39. Maiúsculas: ausência \\
\hline & 10.40. Maiúsculas: uso inadequado \\
\hline & 10.41. Desmembramento de palavras [a gulha / perceber-mos] \\
\hline & 10.42. outros \\
\hline 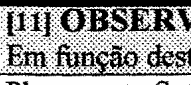 & 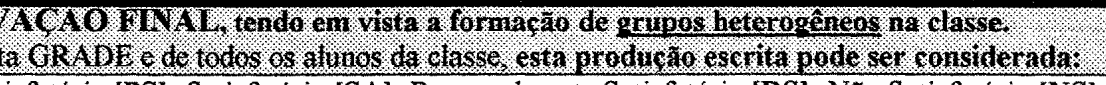 \\
\hline
\end{tabular}

IMPORTANTE:

* Para que haja uma interação de todos os professores de LÍNGUA MATERNA (ensino fundamental, ensino médio e ensino superior) com a GRADE, foram utilizados apenas os termos técnicos que julgamos necessários.

* Agradecimentos ans alunos de Metodologia do Ensino de Língua Portuguesa I e II - TURMAS 1997, 1998, 1999, 2000, 2001 e 2002 do curso de Licenciatura da FEUSP que participaram das reformulações da GRADE.

* As referências bibliográficas desta grade estão inseridas no artigo: SEMEGHINI-SIQUEIRA, Idméa (2002). Questions de lettrement-d'alphabétisation-de littéracie indiquent de nouvelles voies pour la nécessaire refonte de la didactique de la langue maternelle au Brésil. Anais. Colloque: "La Littéracie: le rôle de l'école", Grenoble: IUFM / Université Stendhal Grenoble 3. [Principais autores cilados: BAKHTIN, M.; ADAM, J-M.; BARRÉ-DE MINIAC, C; BRONCKART, J-P; DOLZ, J;; SCHNEUWLY, B.] 


\section{Anexo F}

\section{Entrevista com RBD}

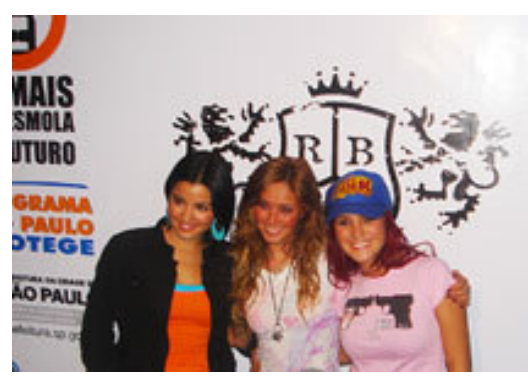

São Paulo, 01 de outubro de 2006

\section{Por: Alexandro Cruz}

Fonte: http://www.obaoba.com.br/noticias/entrevistas_detalhes.asp?ID=13604

Ao entrar na sala, notava-se a aparência de abatidos, devido a seqüência de shows no país. Mesmo assim, todos se esforçaram ao máximo em atender graciosamente as perguntas dos jornalistas.

De cara, o grupo avisou que durante a sua hospedagem em São Paulo, será gravado um vídeo clip pelas ruas paulistanas. O projeto acontece entre segunda e quarta, mas, infelizmente, não sabem os locais das filmagens.

Ao serem questionados quanto aos inúmeros beijos que acontecem durante os shows, os integrantes explicaram que são apenas encenações, isso porque, os personagens namoram na novela e que na vida real, todos são amigos e, acima de tudo, profissionais. E falando na famosa película, também prometeram gravar alguns capítulos da próxima edição no Brasil.

Um dos fatos importantes da coletiva e que chamou bastante a atenção, foi a causa nobre que o sexteto está apoiando. Graças ao sucesso nacional, principalmente na cidade de São Paulo, todos se engajaram no programa "Dê mais que esmola, dê futuro", que luta contra o trabalho infantil no Estado paulista.

Sobre o Brasil, todos confessaram que estão "apaixonados" por churrasco, tanto é, que durante as folgas correm atrás de uma churrascaria e se esbaldam com a tradicional maminha, fraldinha e a suculenta picanha.

Todos finalizaram a coletiva dizendo que não pensam em trabalhos individuais, porque estão focados no grupo e são o grupo. Para eles, o mais importante no momento é o RBD e em relação ao resto, as coisas acontecem com o tempo.

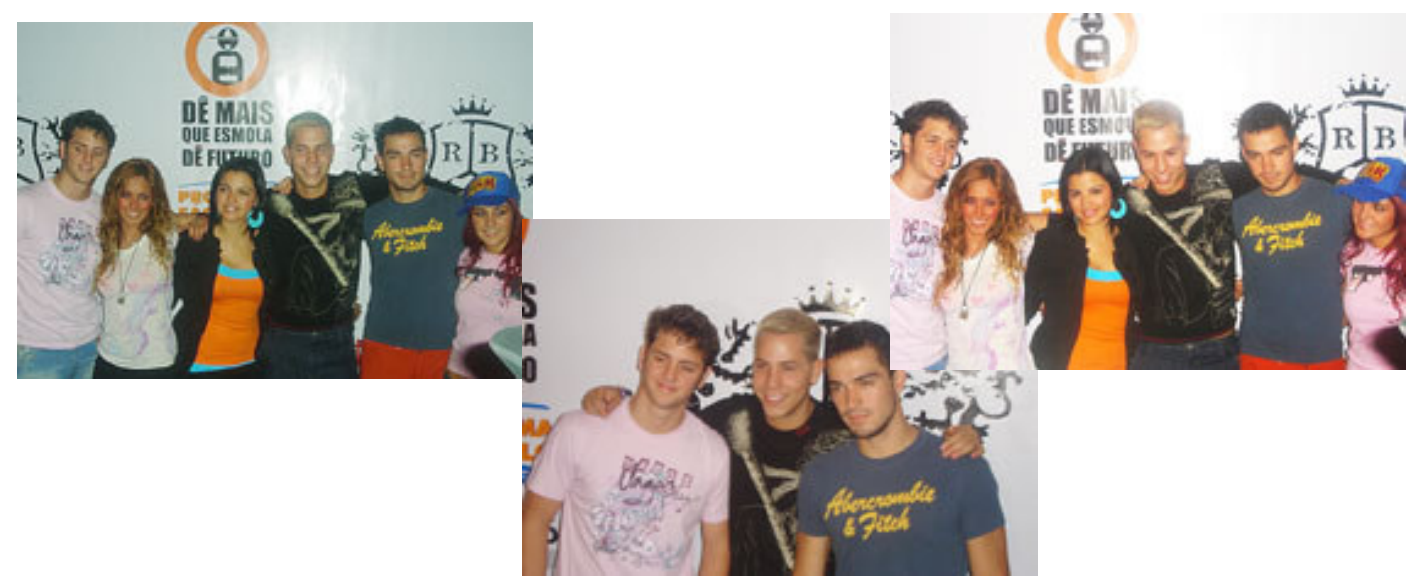




\section{Entrevista com Ronaldinho Gaúcho}

Ivan Padilla, de Madri

Luana Sanchez

Fonte: http://revistaepoca.globo.com/Epoca/0,6993,EPT1087964-1664-4,00.html

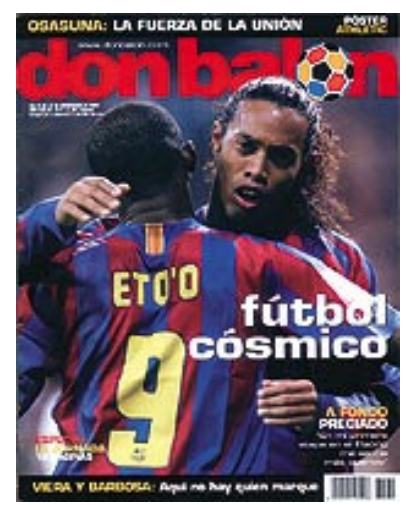

"Minha família é tudo"

Curtir pagode e jogar peladas é a diversão de Ronaldinho Gaúcho

ÉPOCA - Qual foi seu momento mais emocionante no futebol até hoje?

Ronaldinho Gaúcho - É difícil dizer apenas um. São muitos. Disputar e

vencer um Mundial é o sonho de todo jogador. Vencer dentro de um grande clube como o Barcelona e em um campeonato disputadíssimo como a Liga Espanhola também é uma emoção muito grande.

ÉPOCA - Com 25 anos, você já ganhou uma Copa, uma Liga

Espanhola, um prêmio da France Football e, provavelmente, ganhará dois consecutivos da Fifa. O que falta?

Gaúcho - Sou muito jovem. Tenho muito tempo ainda. Mas não fico preocupado com prêmios individuais, pois graças a meus companheiros chego a eles. Pretendo voltar a vencer a Champions League, um sonho do Barcelona e meu. E ganhar minha segunda Copa.

ÉPOCA - Você parece muito caseiro e apegado à família. Assim é o Ronaldinho Gaúcho na intimidade?

Gaúcho - Minha família é a base de tudo. São eles que estão ao meu lado em todos os momentos da minha vida. É difícil estarmos todos juntos e, quando há essa oportunidade, nada melhor do que ficar em casa curtindo um pagode, fazendo um churrasco, batendo uma bolinha com os amigos. 
Anexo G

\section{Entrevista com Ronaldinho Gaúcho - Exercício}

Ivan Padilla, de Madri

Com Luana Sanchez

Fonte: http://revistaepoca.globo.com/Epoca/0,6993,EPT1087964-1664-4,00.html

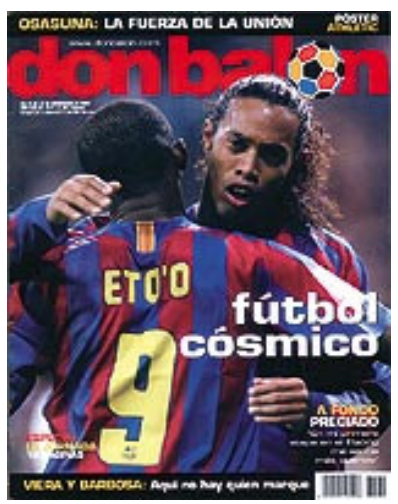

"Minha família é tudo"

Curtir pagode e jogar peladas (ser) a diversão de Ronaldinho Gaúcho

ÉPOCA - Qual (ser) seu momento mais emocionante no futebol até

hoje?

Ronaldinho Gaúcho (ser) difícil dizer apenas um. (ser) muitos.

Disputar e vencer um Mundial (ser) o sonho de todo jogador. Vencer dentro de um grande clube como o Barcelona e em um campeonato disputadíssimo como a Liga Espanhola também (ser) uma emoção muito grande.

ÉPOCA - Com 25 anos, você já (ganhar) uma Copa, uma Liga

Espanhola, um prêmio da France Football e, provavelmente, (ganhar) dois consecutivos da Fifa. O que falta?

Gaúcho (ser) muito jovem. (ter) muito tempo ainda. Mas não (ficar) preocupado com prêmios individuais, pois graças a meus companheiros (chegar) a eles. (pretender) voltar a vencer a

Champions League, um sonho do Barcelona e meu. E ganhar minha segunda Copa.

ÉPOCA - Você (parecer) muito caseiro e apegado à família. Assim (ser) o Ronaldinho Gaúcho na intimidade?

Gaúcho - Minha família (ser) a base de tudo. (ser) eles que estão ao meu lado em todos os momentos da minha vida. (ser) difícil (estar) todos juntos e, quando (haver) essa oportunidade, nada melhor do que ficar em casa curtindo um pagode, fazendo um churrasco, batendo uma bolinha com os amigos. 


\section{Entrevista com RBD - Exercício}

São Paulo, 01 de outubro de 2006

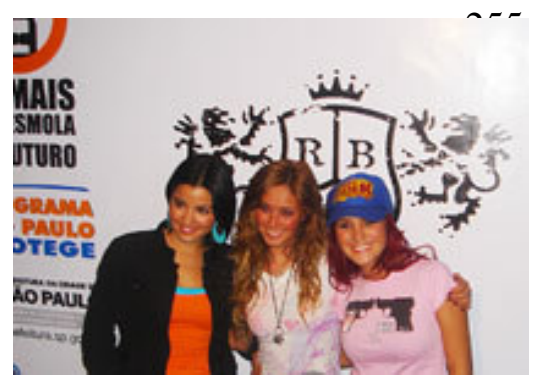

Por: Alexandro Cruz

Fonte: http://www.obaoba.com.br/noticias/entrevistas_detalhes.asp?ID=13604

Ao entrar na sala, (notar)-se a aparência de abatidos, devido a seqüência de shows no país. Mesmo assim, todos se (esforçar) ao máximo em atender graciosamente as perguntas dos jornalistas.

De cara, o grupo (avisar) que durante a sua hospedagem em São Paulo, (ser) gravado um vídeo clip pelas ruas paulistanas. O projeto (acontecer) entre segunda e quarta, mas, infelizmente, não (saber) os locais das filmagens.

Ao (ser) questionados quanto aos inúmeros beijos que (acontecer) durante os shows, os integrantes (explicar) que (ser) apenas encenações, isso porque, os personagens (namorar) na novela e que na vida real, todos (ser) amigos e, acima de tudo, profissionais. E falando na famosa película, também (prometer) gravar alguns capítulos da próxima edição no Brasil.

Um dos fatos importantes da coletiva e que (chamar) bastante a atenção, foi a causa nobre que o sexteto (estar) apoiando. Graças ao sucesso nacional, principalmente na cidade de São Paulo, todos se (engajar) no programa “ (dar) mais que esmola,

(dar)futuro", que (lutar) contra o trabalho infantil no Estado paulista.

Sobre o Brasil, todos (confessar) que (estar) "apaixonados" por churrasco, tanto (ser), que durante as folgas (correr) atrás de uma churrascaria e se (esbaldar) com a tradicional maminha, fraldinha e a suculenta picanha.

Todos (finalizar) a coletiva dizendo que não (pensar) em trabalhos individuais, porque (estar) focados no grupo e (ser) o grupo. Para eles, o mais importante no momento (ser) o RBD e em relação ao resto, as coisas (acontecer) com o tempo.

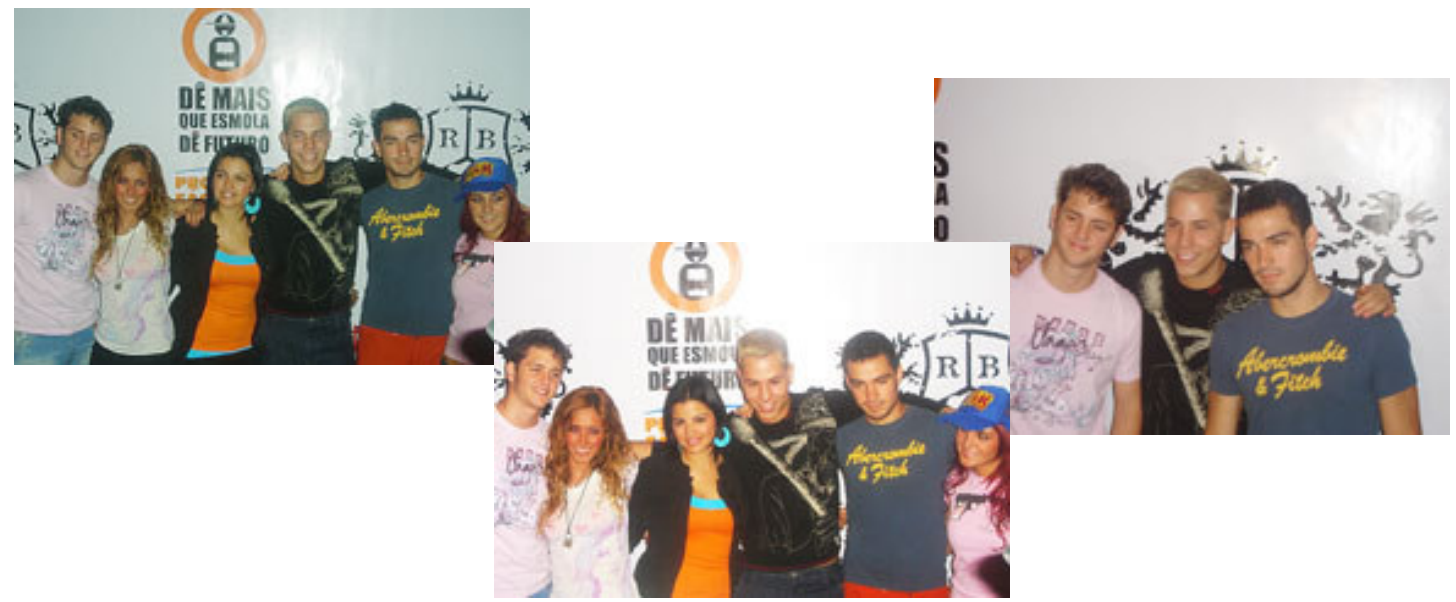




\section{Anexo $\mathbf{H}^{118}$ - Produção Inicial (Segunda Entrada em Campo)}

\section{Produção Inicial Aluno 1}

$\mathrm{C}=$ (entrevistador $)$

$\mathrm{D}=($ entrevistado $)$

C: Qual o seu nome?

D: Arthur

C: Você está fazendo faculdade de que?

D: Faculdade de letras

C: Você gosta?

D: Adoro gosto bastante

C: Você indicaria para alguém este curso?

D: indicaria

C: Você entrou em que ano?

D: entrei em 2003

C: tá brigado

D: De nada

$\mathrm{X}=$ (entrevistador)

$\mathrm{Z}=($ entrevistado $)$

$\mathrm{X}$ : Qual o seu nome?

\section{Z: Anderson}

$\mathrm{X}$ : Você está fazendo faculdade de que?

Z: Faço Faculdade de música.

$\mathrm{X}$ : Você gosta?

Z: Gosto bastante

\footnotetext{
${ }^{118}$ Optou-se por uma transcrição sem a padronização necessária para uma transcrição acadêmica porque estes textos digitados foram utilizados em atividades de reescrita com os alunos. Portanto, entendeu-se que se trataria de uma dificuldade desnecessária para o tipo de trabalho que se propôs. Preferiu-se anexar neste trabalho as versões digitadas, uma vez que elas também fizeram parte das atividades de sala de aula, por uma questão de facilidade de leitura e de uso.
} 
X: Quantos anos tem que você está aqui?

Z: Esse já é o terceiro ano que estou aqui

$\mathrm{X}$ : Você indicaria para alguém?

Z: indiaria sim.

$\mathrm{X}$ : Sua familia te apoiou?

$\mathrm{Z}$ : apoiou bastante meu pai apesar de ser uma coisa assim que as pessoas tem preconceito, mas minha familia apoiou bastante

X: Qual sua idade?

Z: 21 anos.

X: Você gosta do curso que você faz?

$\mathrm{Z}$ : Gosto bastante que você tem que conviver 24 horas direcionado

X: Já compôs alguma música?

Z: Não, eu faço bacharelado em instrumento mesmo. Né, assim agente compõe sempre alguma coisa, mas não é o meu forte, meu forte mesmo é tocar música erudita

\section{Produção Inicial Aluno 2}

Entrevista: Fernanda
A: (entrevistador)
B: (entrevistado)

B: Eu sou fernanda. Eu estou no $1^{\circ}$. ano de odontologia. eu tive que estudar e trabalhar bastante e tive apoio da minha familia. Eu pretendo me informa especializar e trabalhar depois
A: E o que voçe pretende fazer no futuro
B: Eu não sei muito bem mais eu estou na area certa eu estou na area de sirugia.

Entrevista: Fernanda

A: O que voce esta fazendo aqui

B: Eu pretendo arquitetura urbanismo estou aqui há 4 anos ser engenheira e arquitetura 


\begin{abstract}
A: Os professores são muito ezigenti
B: Alguns são e outros não. Eu entri direto no terceiro ano eu não fiz cursinho eu morava em natal. Eu vim fazer a prova porque era conhecido no país.
\end{abstract}

Entrevista:

\title{
A: Foi difícil entra na urp
}

B: Não foi dificil porque a minha area que fasso é uma area facil que é geografia e pretendo dar aulas de geografia fazer um mestrado

A: Os professores são muito ezigenti.

B: São igual a voces uns ezigim pouco outros ezigem mais

A: E isso o que realmente voce esta querendo

B: É mais tem muitas vagas para professores e para profissionais é bem isso que quero.

\section{Produção Inicial Aluno 3}
A: (Entrevistador)
B: (entrevistado)

B: Eu sou Fernanda. Eu estou no $1^{\circ}$. ano de Odontologia. Eu tive que estuda né! Eu tive que batalha bastante. tive apoio da minha familia e foi muito importante Agora eu pretendo me forma, e me especializar e começo a trabalha depois.
A: O que vc pretende fazer mesmo?
B: Eu pretendo fazer cirugias no maxilar.

A: E o que mais o menos você pretende pro seu futuro?

$\mathrm{B}$ : Eu pretendo ficar nessa area que estou hoje eu acho muito importante.

Fernanda

A: O que vc esta fazendo aqui? 
B: eu estou fazendo arquitetura urbanismo e tô no $4^{\circ}$. ano.

A: O que você pretende?

$\mathrm{B}$ : Eu pretendo me forma e engenheiro ou arquiteto

A: Cer professores eles são muito exigente?

B: alguns são, eles pedem mais por notas e trabalhos. Entrei direto no $3^{\circ}$. ano e não fiz cursinho!

Eu vim de Natal e vim fazer a prova porque é conhecida no país, eu vim fazer e acabei passando na sorte. E que é muito reconhecido.

A: Pra entrar na USP foi muito difícil?

B: É até foi fácil porque é um curso que não é muito concorrido.

Meus planos em primeiro lugar da aula que é uma coisa que acho que so cápaz de fazer. Não pretendo sair daque fazer um mestrado chego o mais longe na minha carreira.

Cer professor eu acho que é igual o de vcs alguns leige muito e outros menos.

A: É difícil o que vc está querendo?

B: A profissão voce esta falando vaga para professor tem muito no mercado de trabalho entrar não é tão difícil. Agora pra trabalhar com outra coisa já é mais difícil.

\section{Produção Inicial Aluno 4}

Qual é o seu nome?

R: Milena

Qual sua idade?

R: 21 anos

Qual curso você faz?

R: Odontologia

O que levou você fazer o curso?

R: Há, eu tinha primos que já fizeram odonto aí, eu visitei a clinica e gostei da profissão.

Seus pais aceitaram?

$\mathrm{R}$ : aceitaram.

Foi difícil?

R: Foi, porque eu vim de escola publica, aí pra estudar aqui é difícil, tive que fazer cursinhos, ai consegui passar. 
(comentou: é eu acho que a maioria do pessoal é de escola pública né?

R: É não, nem sempre né, a maioria é de escola particular

Há, eu acho que só obrigada.

R: Há, de nada.

\section{Produção Inicial Aluno 5}

Qual o seu nome?

\section{R: Alexsander DXXX MXXXXX}

Sua idade?

R: 29 anos

Qual o curso que você faz?

$\mathrm{R}:$ Eu faço Doutorado de Medicina Veterinaria.

O que levou você à fazer este curso?

R: Há, desda infancia, eu sonhei em ser médico veterinario, depois de formado, eu senti necessidade de me aperfeiçoar na area que eu mais gostava, que era Animais Silvestres.

É dificil o que você faz?

R: Dificil, eu acho que é bastante relativo, porque eu acho que você gosta mesmo daquilo, o dificil desaparece, é quanto mais dificil, mais prazeroso.

É ...teve muitas dificuldades?

R: É, foi dificil um pouco, à vinda pra São Paulo, porque eu sou do Paraná, me formei no Rio Grande do Sul, fiz um mestrado, e estou fazendo doutorado aqui na USP. O mais dificil foi a adaptação, na cidade diferente viver em São Paulo realmente, não é tão facil!

Seus pais te apoiaram?

R: Sempre me apoiaram, desde o $1^{\circ}$. ano, desde a $8^{\mathrm{a}}$. série, desde sempre, e até hoje me apoiam e são meus maiores incentivadores.

E você estudou em escola particular, ou escola pública mesmo?

R: Eu estudei em escola pública, fiz o $1^{\circ}$. e o $2^{\circ}$. grau e a faculdade em escola pública.

E foi difícil né, entrar na USP?

R: É, aquilo o que eu falei dinovo, eu acho que quando você qué, tem gente que pode ter uma facilidade maior, mas se você quiser mais que isso, você supera!

Então, a gente queria te agradecer, e uma boa tarde! Obrigado. 


\section{Produção Inicial Aluno 6}

Qual é o seu nome?

R: Meu nome é Gilberto RXXX,

Sua idade?

R: Eu tenho 23 anos

Qual o curso que você está fazendo?

$\mathrm{R}$ : Eu estudo arquitetura

O que ti levou a fazer o curso?

R: Há, eu gostei sempre desde pequeno gostava muito de geografia, gosto muito de publicidade, então eu quis engressar na carreira de arquiteto

Seus pais sempre te apoiaram?

R: Sempre me apoiaram,

E você pode explicar um pouquinho do que é arquitetura?

R: Bom, o curso da FAU né é um curso bastante amplo, no sentido em que a gente não só estuda arquitetura mas, estuda bastante urbanismo, estuda bastante também eu acho, a relação do homem com a cidade e com o meio ambiente.

É... e desde pequeno você gostava?

$\mathrm{R}$ : Desde pequeno eu gostava.

Seus pais te apoiaram?

R: Apoiaram apesar de meus pais não serem arquitetos, mais apoiaram e me incentivaram.

E você estudou em escola particular ou escola publica?

R: Estudei em escola particular desde pequeno.

Já foi difícil entrar na USP estudando em escola particular, você acha que seria mais difícil se tivesse estudado em escola pública?

R: Olha, eu acho que talvez fosse, eu acho que o colégio que eu fiz não preparou bem, pro vestibular, eu fiz dois anos de cursinho, mais acho que talvez, pela qualidade do ensino público atual, eu acho que talvez o caminho podesse ser mais difícil.

Hoje você pode dizer que é um homem realizado?

R: Há, de certa forma sim, eu gosto em termo assim da faculdade eu gosto bastante do lugar que estudo e tenho interesse, eu acho que foi uma espectativa que se realizou. 


\section{Produção Inicial Aluno 7}

Nome: Karen Idade: 23 anos

Facu: Letras

A: Que parte da facu vc feiz?

B: fiz letras

A: Quando foi que vc decidiu fazer letras?

B: Comecei a pensar quando estava no colegial

A: + deste pequena vc queria fazer letras?

B: Fiquei em duvida entre letras, pedagogia, história e direito, ai escolhi letras.

A: Vc acha isso legal pra vc?

B: O curso? Adoro o curso!

\section{Produção Inicial Aluno 8}

Nome: Rafael idade:

Facudade: Música

A: Desde que idade vc começou a pensar nisso?

B: Eu estudo deste meus 8 anos de idade

A: Vc pretende continuar sua facudade, pro seu futuro?

B: É, vou terminar ela conserteza e sempre trabalhar com música.

A: Vc indicaria essa profisão para outras pessoas?

B: A profisão em, sim eu indico o curso só é que não é tão necessario, vc não necessita tanto do diploma para esece a profisão

A: Porque motivo assim? Ter levou a fazer essa facudade?

B: Mas pro uma questão tão social, de vc tá fazendo uma facudade, do que uma necessidade, eu sempre estudei com bons professores, na verdade eu sempre ficava naquela dúvida de fazer uma facudade e ai eu prestei aqui e tô fazendo aqui!

A: Deste pequeno vc sonho com isso? 
B: Desde pequeno, em trabalhar com música sempre.

\section{Produção Inicial Aluno 9}

Nome: Rafael

Idade:

Facudade: Musica

desde qui idade voce comesso pensa nisso?

eu estudo desde meus 8 anos di idade

voce pretende continuar sua facudade pro seu futuro?

é vou termina ela concerteza e sempre trabalha com musica

voce indicaria essa profisam pra otra pessoa?

a profisam sim eu indico o curso só e que nam e tam nessesario voce nam nessesita tanto do diploma

porque motivo assim? di levou faze essa facudade?

mais pro uma questam social di voce tá fazendo uma facudade do que uma nessesidade 


\section{Anexo I ${ }^{119}$ - Produção Final (Segunda Entrada em Campo)}

\section{Produção final Aluno 1}

$\mathrm{C}=($ Entrevistador $)$

$\mathrm{D}=($ Entrevistado $)$

$\mathrm{C}=$ Qual o seu nome?

$\mathrm{D}=$ Arthur.

$\mathrm{C}=$ Você está fazendo Faculdade de que?

$\mathrm{D}=$ Faculdade de letras.

$\mathrm{C}=$ Você gosta?

$\mathrm{D}=$ Adoro, gosto bastante.

$\mathrm{C}=$ Você indicaria para alguém este curso?

$\mathrm{D}=$ indicaria.

$\mathrm{C}=$ Você entrou em que ano?

$\mathrm{D}=$ entrei em 2003.

$\mathrm{C}=$ Tá obrigado.

$\mathrm{D}=$ De nada .

$\mathrm{X}=$ (entrevistador $)$

$\mathrm{Z}=$ (entrevistado)

$\mathrm{X}=$ Qual o seu nome?

$\mathrm{Z}=$ Anderson.

$\mathrm{X}=$ Você está fazendo Faculdade de que?

$\mathrm{Z}=$ Faço Faculdade de música.

$\mathrm{X}=$ Você gosta?

$\mathrm{Z}=$ Gosto bastante.

${ }^{119}$ Ibdem ao Anexo H. 
$\mathrm{X}=$ Quantos anos tem que você está aqui?

$\mathrm{Z}=$ Esse já é o terceiro ano que estou aqui.

$\mathrm{X}=$ Você indicaria para alguém?

$\mathrm{Z}=$ indicaria $\operatorname{sim}$.

$\mathrm{X}=$ Sua família te apoiou?

$\mathrm{Z}=$ Apoiou bastante meu pai apesar de ser uma coisa assim que as pessoas tem preconceito, mas minha família apoiou bastante.

$\mathrm{X}=$ Qual sua idade?

$\mathrm{Z}=21$ anos.

$\mathrm{X}=$ Você gosta do curso que você faz?

$\mathrm{Z}=$ Gosto bastante, que você tem que conviver 24 horas direcionado.

$\mathrm{X}=$ Tá obrigado.

$\mathrm{Z}=\mathrm{De}$ nada.

\section{Produção Final Aluno 2}

entrevista

B: Sou Fernanda. Eu estou $1^{\circ}$. ano de odontologia. Eu tive que estudar e trabalhar bastante e tive apoio da minha família. Eu pretendo me formar especializar e trabalhar depois.

A: E o que você pretende fazer no futuro?

B: Eu não sei muito bem, mais eu estou na área certa, na área de cirurgia.

Entrevista: Fernanda

A: O que você está fazendo aqui?

B: Eu pretendo arquitetura urbanismo. Estou aqui há 4 anos. Quero ser engenheira e arquiteta.

A: Os professores são muito exigente?

B: alguns são e outros não. Eu entrei direto no terceiro ano, eu não fiz cursinho. Eu morava em natal. Eu vim fazer a prova porque era conhecida no país. 


\section{Produção final Aluno 3}
A: (entrevistador)
B: (entrevistado)

\section{$1^{\circ}$. Entrevista}

B: Eu sou Fernanda. Eu estou no $1^{\circ}$. ano de Odontologia. Eu tive que estudar né! Eu tive que batalhar bastante. Tive o apoio da minha família e foi muito importante. Agora eu me formo, e me especializar e começar trabalhar depois.

A: E o que você pretende para seu futuro?

B: Eu pretendo ficar nessa área que estou hoje, eu acho muito importante.

A: O que você pretende fazer mesmo?

B: Eu pretendo fazer cirurgias no maxilar.

Fernanda

$2^{\mathrm{a}}$. Entrevistada

A: O que você está fazendo aqui?

B: Eu estou fazendo arquitetura urbanismo e estou no $4^{\circ}$. ano.

A: Seus professores, são muito exigentes?

B: Alguns são, eles pedem mais por notas e trabalhos. Entrei direto no $3^{\circ}$. ano e não fiz cursinho. Eu vim de Natal e vim fazer a prova porque é conhecida no país, eu vim fazer e acabei passando na sorte. E que é muito reconhecido.
A: Para entrar na USP foi muito díficil?
B: É até foi fácil porque é um curso que não é muito concorrido.

A: O que você pretende para seu futuro?

B: Meus planos em primeiro lugar, é da aula que é uma coisa que acho que sou capaz de fazer, pretendo fazer um mestrado e chega mais longe na minha carreira.

A: Os professores são muito exigentes?

B: Os professores, eu acho que é igual o de vocês, uns exigem mais e outros exigem menos. A: É difícil o que você está querendo? 
B: A profissão você está falando? Vaga para professor tem muito no mercado de trabalho, entrar não é tão difícil. Agora pra trabalhar com outra coisa já é mais difícil.

\section{Produção final Aluno 4}

A Escola XXXXXXXX foi na USP e entrevistou vários alunos pra saber como foi que eles entraram lá! Confira agora uma entrevista com uma futura-dentista!

Qual é o seu nome?

R: Milena.

Qual sua idade?

R: 21 anos.

Qual curso você faz?

R: Odontologia.

O que levou você fazer o curso?

R: Eu tinha primos que já fizeram Odontologia. Eu visitei a clínica e gostei da profissão!

Seus pais aceitaram?

R: Aceitaram.

Foi difícil?

R: Foi, porque eu vim de escola pública, para entrar aqui é difícil, eu tive que fazer cursinhos, até consegui passar! Acho que a maioria do pessoal é de escola pública, né?

R: Nem sempre, a maioria é de escola particular!'

Eu acho que só, obrigada!

R: De nada!

\section{Produção final Aluno 5}

Olha o XXXXXX aí, gente! A sala do minicurso de leitura e redação foram para USP. Ó nóis na fita!

A: Qual é o seu nome? 
B: Alexander DXXX MXXX.

A: Sua idade?

B: 29 anos.

A: Qual o curso que você faz?

B: Eu faço Doutorado de Medicina Veterinária.

A: O que levou você a fazer este curso?

B: Desde a infância eu sonhei em ser Médico Veterinário, depois de formado, eu senti necessidade de me aperfeiçoar na área que eu mais gostava, que era animais silvestres.

A: É difícil o que você faz?

B: Difícil é bastante relativo, porque eu acho que se você gosta mesmo daquilo, o difícil desaparece. E, quanto mais difícil, mais prazeroso!

A: E, teve muitas difículdades?

B: É, foi difícil, um pouco. A vinda para São Paulo, porque eu sou do Paraná. Me formei no Rio Grande do Sul, fiz um mestrado e estou fazendo Doutorado aqui na USP. O mais difícil foi a adaptação na cidade diferente. Viver em São Paulo realmente, não é tão fácil!

A: Seus pais te apoiaram?

B: Sempre me apoiaram, desde o $1^{\circ}$. ano, desde a $8^{\mathrm{a}}$. série, desde sempre. Até hoje me apoiam e são meus maiores incentivadores!

A: E você estudou em escola particular, ou em escola pública mesmo?

B: Eu estudei em escola pública, fiz o $1^{\circ}$. ano e o $2^{\circ}$. grau e a faculdade em escola pública.

A: E foi difícil, entrar na USP?

B: É, aquilo o que eu te falei de novo, eu acho que quando você quer, tem gente que pode ter uma facilidade maior, mais se você quiser mais do que isso, você supera!

A: Então, a gente queria te agradecer, e uma boa tarde. Obrigada!

\section{Produção final Aluno 6}

Um dia também pode ser você! Entrevista do pessoal da $7^{\text {a }}$. C lá na USP

Qual é o seu nome?

R: Meu nome é Gilberto RXXXX.

Sua idade? 
R: Eu tenho 23 anos.

Qual o curso que você está fazendo?

$\mathrm{R}$ : Eu estudo arquitetura.

O que te levou a fazer o curso?

$\mathrm{R}$ : Eu gostei sempre de geografia, gosto muito de publicidade, então eu quis ingressar na carreira de arquiteto.

Seus pais sempre te apoiaram?

R: Sempre me apoiaram.

E você pode explicar um pouquinho do que é arquitetura?

R: Bom, o curso da FAU é um curso bastante amplo, no sentido em que a gente não só estuda arquitetura mas estuda bastante urbanismo, estuda bastante também a relação do homem com a cidade e com o meio ambiente.

É... e desde pequeno você gostava?

$\mathrm{R}$ : Desde pequeno eu gostava.

Seus pais te apoiaram?

R: Apoiaram apesar de meus pais não serem arquitetos, mais apoiaram e me incentivaram. E você estudou em escola particular ou escola publica?

$\mathrm{R}$ : Estudei em escola particular desde pequeno.

Já foi difícil entrar na USP estudando em escola particular, você acha que seria mais difícil se tivesse estudado em escola pública?

R: Olha, eu acho que talvez fosse, eu acho que o colégio que eu fiz não preparou bem pro vestibular, eu fiz dois anos de cursinho, mais acho que talvez, pela qualidade do ensino público atual, eu acho que talvez o caminho pudesse ser mais difícil.

Hoje você pode dizer que é um homem realizado?

R: De certa forma sim, eu gosto da faculdade, eu gosto bastante do lugar que estudo e tenho interesse, eu acho que foi uma expectativa que se realizou.

\section{Produção final Aluno 7}

Nome: Karen

Idade: 23 anos

Faculdade: Letras 
Que parte da faculdade você fêz?

R: Fiz letras.

Quando foi que você decidiu fazer letras?

$\mathrm{R}$ : Comecei a pensar quando estava no colegial.

Mais deste pequena você queria fazer letras?

R: Fiquei em dúvida entre letras, pedagogia, história e direito, aí escolhi letras!

Você acha isso legal pra você?

R: O curso? Adoro o curso!!!

\section{Produção final Aluno 8}

Nome: Rafael

Idade:

Faculdade: Música

A: Desde que idade você começou a pensar nisso?

B: Eu estudo desde meus 8 anos de idade.

A: Você pretende continuar sua faculdade pro seu futuro?

B: É, vou terminar ela com certeza e sempre trabalhar com músicas.

A: Você indicaria essa profissão para outras pessoas?

B: A profissão em, sim eu indico o curso só é que não é tão necessita tanto do diploma para exerce a profissão.

A: Porque motivo assim? Te levou a fazer essa faculdade?

B: Mais por uma questão tão social, de você tá fazendo uma faculdade, do que uma necessidade, eu sempre ficava naquela e ai eu prestei aqui e tô fazendo aqui.

A: Desde pequeno você sonho com isso?

B: desde pequeno, em trabalhar com música sempre.

\section{Produção final Aluno 9}

Nome: Rafael

Idade: 
Facudade: Musica

A: Desde qui idade voce comesso pensar nisso?

B: Eu estudo desde meus 8 anos de idade.

A: Você pretende continuar sua facudade pro seu futuro?

B: Vou terminar ela com certeza e sempre trabalhar com musica.

A: Você indicaria essa profissão pra otras pessoas?

B: A profissão sim eu indico o curso só é que não é tão necessario você não necessita tanto do diploma.

A: Porque motivo assim? Te levou fazer essa facudade?

B: Mas pro uma questão social de você tá fazendo uma facudade do que uma necessidade. 